\title{
The Impact of Location and Proximity on Consumers' Willingness to Pay for Green Electricity: The Case of West Virginia
}

\author{
Kofi Nkansah
}

Follow this and additional works at: https://researchrepository.wvu.edu/etd

\section{Recommended Citation}

Nkansah, Kofi, "The Impact of Location and Proximity on Consumers' Willingness to Pay for Green Electricity: The Case of West Virginia" (2016). Graduate Theses, Dissertations, and Problem Reports. 6323.

https://researchrepository.wvu.edu/etd/6323

This Dissertation is protected by copyright and/or related rights. It has been brought to you by the The Research Repository @ WVU with permission from the rights-holder(s). You are free to use this Dissertation in any way that is permitted by the copyright and related rights legislation that applies to your use. For other uses you must obtain permission from the rights-holder(s) directly, unless additional rights are indicated by a Creative Commons license in the record and/ or on the work itself. This Dissertation has been accepted for inclusion in WVU Graduate Theses, Dissertations, and Problem Reports collection by an authorized administrator of The Research Repository @ WVU.

For more information, please contact researchrepository@mail.wvu.edu. 
The Impact of Location and Proximity on Consumers' Willingness to Pay for Green Electricity: The Case of West Virginia.

\title{
Kofi Nkansah
}

Dissertation submitted to the

\author{
Davis College of Agriculture, Natural Resources and Design \\ at West Virginia University \\ in Partial Fulfillment of the Requirements for the Degree of
}

\author{
Doctor of Philosophy \\ in \\ Natural Resource Economics \\ Alan R. Collins, Ph.D., Chair \\ Tesfa G. Gebremedhin, Ph.D. \\ Stratford Douglas, Ph.D. \\ Wesley J. Burnett, Ph.D. \\ Christine M. Risch, M.S.
}

Agricultural and Resource Economics Program

Division of Resource Management

West Virginia University

Morgantown, West Virginia

2016

Keywords: Wind Energy, Natural Gas, Attitudes and Preferences for Renewable Energy, Mixed logit Model, Renewable Portfolio Standards.

Copyright 2016 Kofi Nkansah 


\section{ABSTRACT \\ The Impact of Location and Proximity on Consumers' Willingness to Pay for Green Electricity: The Case of West Virginia.}

\section{Kofi Nkansah}

During the 2015 legislative session, West Virginia lawmakers passed a bill to repeal the Renewable and Alternative Energy Portfolio Standards Act of 2009 (ARPS). Legislators stated concerns about ARPS's impacts on coal industry related jobs in the state as the major factor driving this repeal. However, no comprehensive study on public acceptance, opinions, or willingness to pay (WTP) for renewable/and or alternative sources of electricity within West Virginia was used to inform this repeal decision. As the state of West Virginia struggles to find the right path to expand its renewable energy portfolio, public acceptance of renewable electricity is crucial to establishing a viable market for these forms of energy and also ensure the long-term sustainability of any RPS policy that may be enacted in the future. This study sought to assess consumers' preferences, attitudes and WTP for renewable and alternative electricity in West Virginia. The monetary values that consumers placed on proximity as an attribute of a renewable and alternative electricity generation source were also estimated.

Two counties in West Virginia were selected as study areas based on the types of electricity generation facility that already exist in each county -one county with coal-fired power plants (Monongalia County) and another with both a coal-fired power plant and a wind farm (Grant County). A forced choice experiment survey was used with attributes that varied in source of energy (wind versus natural gas), proximity of the generation source relative to the respondent's residence (near, moderate or far) and an additional premium per month on the electric bill (varying from $\$ 1$ to $\$ 15$ ). Respondents were asked to choose between generating $10 \%$ of the electricity supplied to them from wind or natural gas. Random samples of 1500 residents from each county were sent surveys and response rates were 27.0\% (Monongalia) and 35.3\% (Grant). A Mixed logit econometric models were used to analyze consumer choices with utility models. WTP for energy source and proximity attribute levels were computed using parameter estimates from these utility models. Statistically different models were developed for each county.

Results from the study showed that respondents in both counties had preferences for electricity generated from wind compared to natural gas. A majority of the sampled populations chose the wind option, $62.0 \%$ in Monongalia County and 60.0\% in Grant County. The sampled 
populations in Monongalia and Grant Counties were willing to pay a weighted mean of $\$ 21.59$ and $\$ 9.87$ per month, respectively, for $10 \%$ of their electricity to be generated from wind over natural gas. Despite this large difference, county level means were not statistically different. On aggregate, a positive social benefit per year would be derived from generating $10 \%$ of electricity supplied to consumers in Monongalia County ( $\$ 2.5$ million) and Grant County ( $\$ 186$ thousand) from wind relative to natural gas. Similarly, the most social benefit would be derived from siting wind turbines at "far" locations from residents in both counties.

Both county level sampled populations were willing to pay a higher premium to site wind turbines or a natural gas-fired power plant at the farthest location relative to the baseline location (near a respondent's current residence). Grant County respondents were willing to pay a slightly higher positive premium (mean of $\$ 11.71$ per month) to site wind turbines at the farthest location than respondents in Monongalia County (mean of \$10.14 per month). The mean WTP to site a natural gas-fired power plant at the farthest location in Monongalia County (\$13.06) and Grant County (\$13.47) were not statistically different from each other.

Results from this study suggest that the decision for an outright repeal of the ARPS bill was flawed. Based on Monongalia and Grant County populations, there are social benefits derived from generating $10 \%$ of the electricity supplied to consumers in West Virginia from renewable and alternative energy sources, and wind is preferred to natural gas. This repeal implies there are few, if any, benefits. Given this repeal, I suggest that a voluntary green pricing program with a focus on wind energy serve as an alternative renewable energy policy in West Virginia. Under such a policy, consumers who are concerned about the environment and are willing to pay a positive premium for renewable electricity would be able to opt into the program. Premiums paid by participants of such a program can be used to increase the renewable energy share in West Virginia's energy portfolio. 


\section{ACKNOWLEDGMENTS}

This journey started way back before I even started college. As a young kid I had a dream to pursue a Doctorate Degree at some point in my life. This dream would not have happened without God! Thanks to God for his love, mercies and strength. To my wife Laurie, thank you for your patience and volunteer editing job. I would like to thank Dr. Alan Collins, my major advisor for his patience and mentorship. It's been a long partnership, and I enjoyed every moment of it. You have taught me a lot more than you can imagine.

To Dr. Ben Dawson-Andoh, thank you for believing in me! I will also like to thank my graduate committee members for their time and valuable advice. To all the faculty and staff in the division of resource management, thank you for your advice, tolerance and help through all the years. To my mum; thank you for your constant prayer and encouragement.

Lastly, to my dad who never neglected his duty as a father. Thank you for your support and all the great lesson of life. To paraphrase an anonymous source: “...My dad gave me three valuable things in life; a good education, work ethic and no money".

Thank you all! 


\section{Contents}

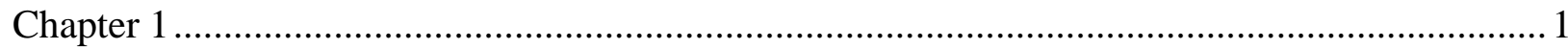

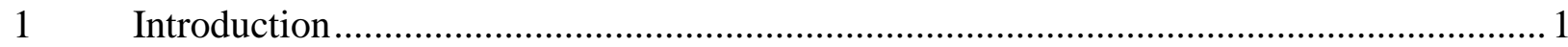

1.1 Background of Study \& Problem Statement........................................................... 1

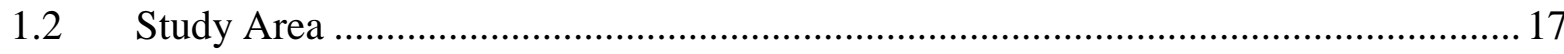

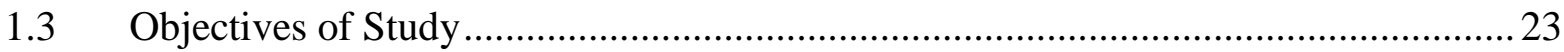

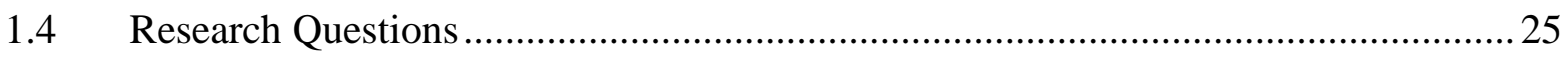

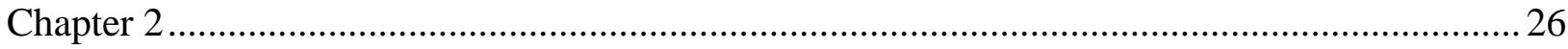

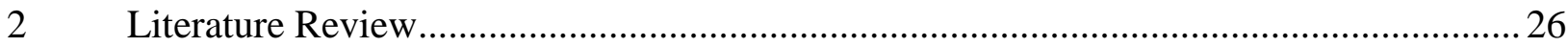

2.1 Elicitation of Value placed on Green Energy Attributes ........................................2 26

2.2 Consumers WTP for Environmental and Non Environmental attributes ....................2 28

2.3 Willingness to Pay and an Individual's Social Characteristics.....................................32

2.4 Consumers Preference and Attitude towards Green Energy .........................................33

2.5 The Proximity Hypothesis and Consumers' Attitude towards Green Energy ..............34

2.6 Willingness to Pay or Accept Compensation for Green Power and Proximity ........... 37

$2.7 \quad$ Willingness to Pay for Green Electricity and Location ................................................ 38

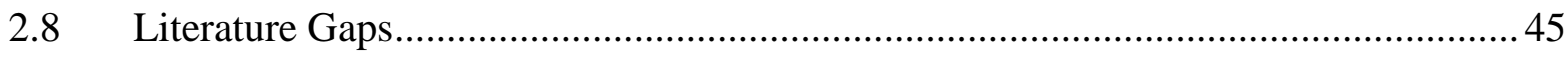

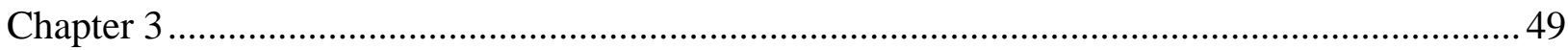

3 Model Theory: Econometric Basis of Choice Experiment ………………………........... 49

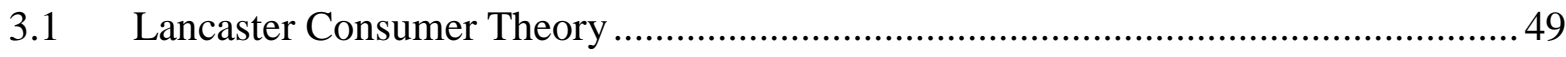

3.2 Random Utility Theory (RUT) and Individuals' Choice Model …............................50

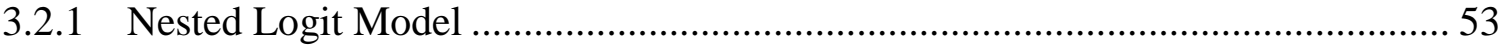

3.2.2 Mixed Logit or Random Parameter Model ....................................................... 54

3.3 Log Likelihood Ratio Test: Comparing Utility Models for Two Populations

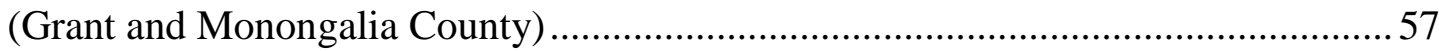

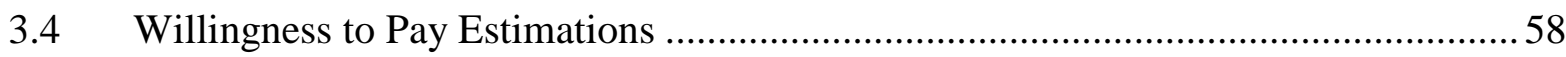

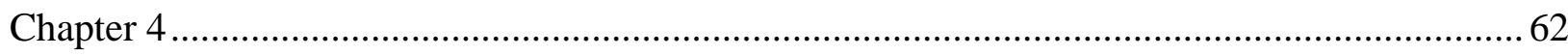

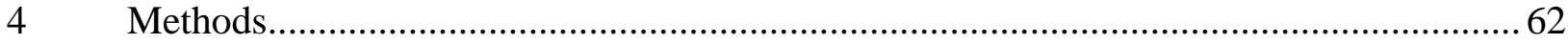

4.1 Initial Questionnaire on Perception of Attributes of Interest..................................... 62 
4.2 Administering Initial Questionnaire (Intercept \& Semi-Structured Focus

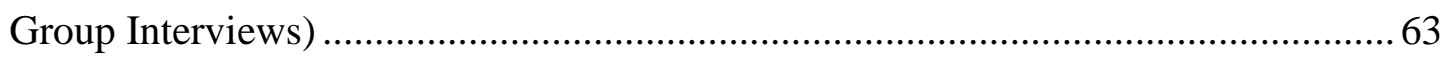

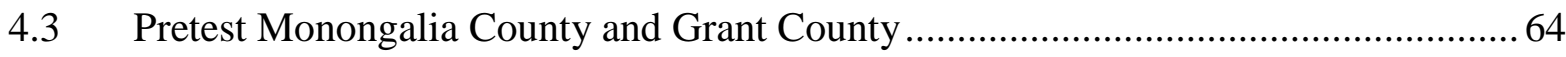

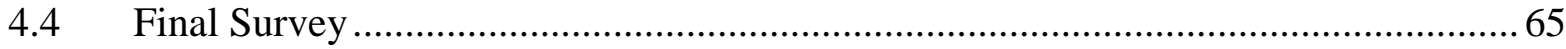

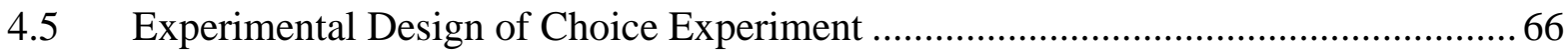

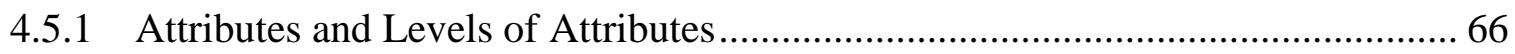

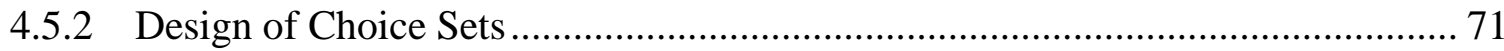

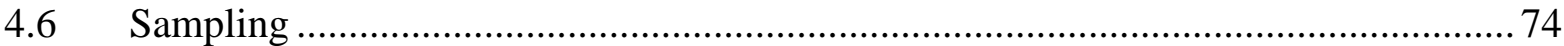

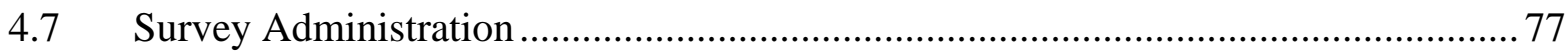

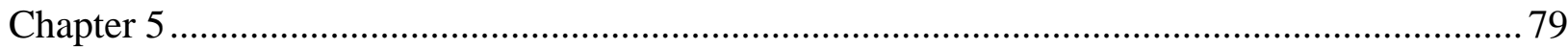

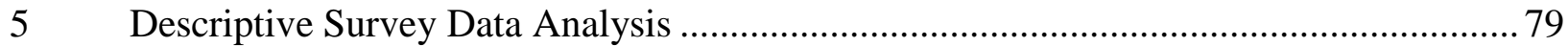

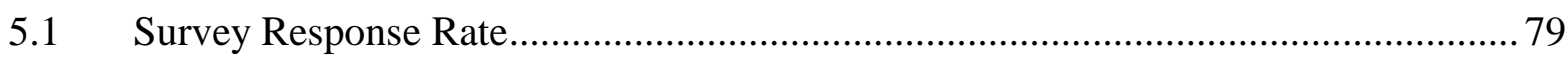

5.1.1 Summary Characteristics of Respondents Population ................................... 82

5.2 Familiarity with West Virginia's Alternative and Renewable Portfolio Standard and Electricity Generation in General. .............................................. 85

5.3 Preferences and Attitudes towards the Electricity Generated from Alternative, Renewable and Non-Renewable Sources in West Virginia.................................... 91

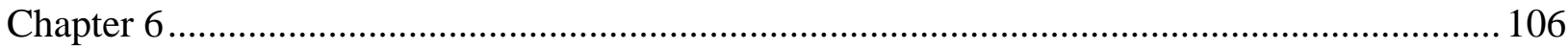

6 Choice Experiment Results and Willingness to Pay Estimation ................................ 106

6.1 Descriptive statistics of respondents' choices.................................................. 106

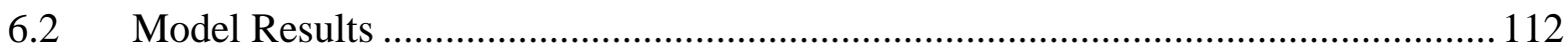

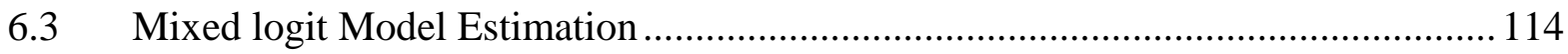

6.4 Random Parameters Estimation ..................................................................... 114

6.5 Derived Standard Deviations of Random Parameters ......................................... 116

6.6 Non Random Parameters / Fixed Parameters ................................................... 118

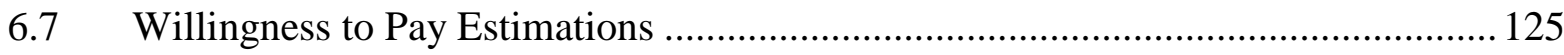

6.7.1 Willingness to Pay for Proximity: Wind Turbine and Natural Gas-fired

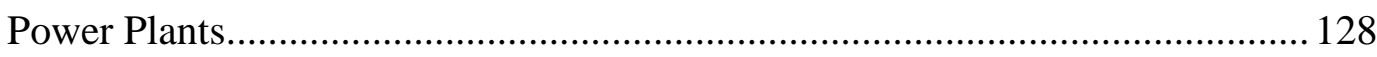

6.7.2 Willingness to pay for Electricity Generated from Wind vs. Natural Gas ......... 134 
6.7.3 Willingness to Pay for Proximity: See vs. Do Not See Wind Turbines (Grant County)

6.7.4 Aggregated WTP for Proximity \& Energy Source (Weighted Sampled

Population)

6.7.5 Test of Hypothetical Bias in Uncertain Choices (Overstating WTP) 145

6.7.5.1 An Assessment of Factors Influencing Respondents' Certainty

Level

6.7.6 Test of Choice Order Effect on Utility Model (Position Order Effect) .............. 150

6.7.7 Effect of Perceived Positive Employment Impact of Coal on Choices .............. 152

6.7.8 Assessing the Effect of Weighting Observation ............................................ 156

Chapter 7 157

7 Conclusions, Policy Implications, and Limitations

7.1 Policy Implication: The ARPS Policy Repeal vs. Voluntary Green Pricing Policy 166

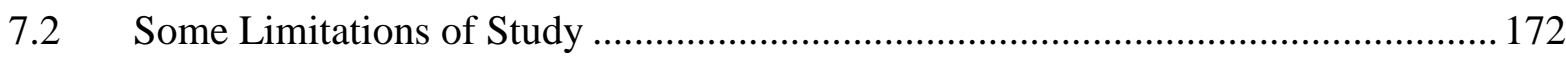

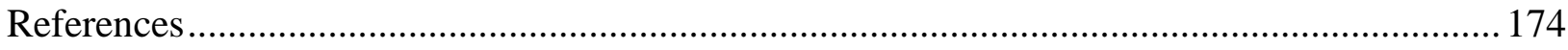

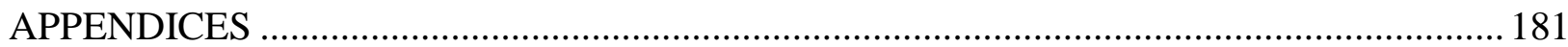

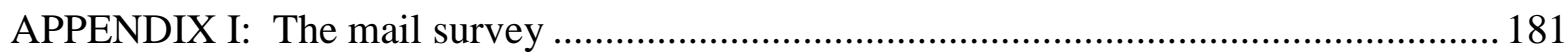

APPENDIX II: Map of West Virginia identifying Monongalia County and Grant County. 205

APPENDIX III: Multinomial logit models of Grant County and Monongalia County sampled populations. 206

APPENDIX IV: Mixed logit Model for the Pooled Population (Monongalia County and Grant County).

APPENDIX V: Mixed logit Model of Respondents with Wind Turbines within Sight from Residence vs. Wind Turbines not within Sight from Residence (Grant County). 208

APPENDIX VI: Summary Statistics of Choices vs. Certainty Levels. 209

APPENDIX VII: Multinomial Logit Models of observations Separated by Certainty Levels of Choices Made. 210 
APPENDIX VIII: Willingness to Pay Estimations for Observations Separated by Certainty Levels of Choices Made.

APPENDIX IX: Multinomial Logit Models of Observations Separated by Order of

Choice Sets (Choice set 1 vs. Choice set $2 \&$ 3) ..................................................... 214

APPENDIX X: Assessing the Effect of Weighting Observation (Weighted and

Unweighted Multinomial Logit Models.

APPENDIX XI: Assessment of the Representativeness of Sample Population

Compared to West Virginia Population.

APPENDIX XII: Discussion on the "Far Away" Location Attribute as a Within State

vs. Potential Out of State Location. 


\section{LIST OF TABLES}

Table 4.1. Appendix of survey: Impacts of wind and natural gas power based on location ......... 70

Table 4.2. List of attribute and levels used in choice experiment design. .................................... 71

Table 5.1. Summary of sample size and survey response rate................................................... 80

Table 5.2. Expected sample size based on probability sampling methodology (Dillman, 2000)

Table 5.3. Summary of sample characteristics and population characteristics............................. 82

Table 5.4. Expected sample size vs. actual sample size based on age and education level........... 84

Table 5.5. Summary of weighting characteristics of populations................................................ 85

Table 5.6. Response to survey question \#4: How familiar are you with the "Alternative and

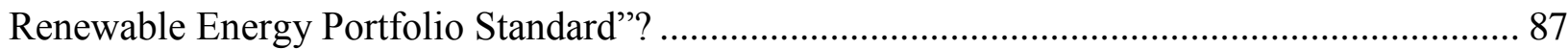

Table 5.7. Response to survey question \#5: Do you support this mandate?................................. 88

Table 5.8. Response to survey question \#6: What is your level of familiarity on how each of these energy sources is converted into electricity?

Table 5.9. Summary of responses to survey questions \#7 and \#8: How often do you notice wind turbines or a coal power plant at the following locations? ........................................................... 90 Table 5.10. Response to survey question \#9: In your opinion, what strategies should Mon Power or Potomac Edison use to increase its renewable and alternative electricity generation capacity?

Table 5.11. Response to survey question \#10: What are your general attitudes toward electricity generation facilities that utilize these sources of energy?

Table 5.12. Response to survey question \#11: In your opinion, which of the following electricity generation sources have the most positive impact on the following?. 96 Table 5.13. Response to survey question \#12: In your opinion, which of the following electricity generation sources have the most negative impact on the following?

Table 5.14. Response to survey question \#13: You are presented with a series of statements. Please indicate your strength of agreement or disagreement with each statement that best represents your opinion? 
Table 5.15. Response to survey question \#17: Investments in renewable and alternative electricity generation facilities have many economic benefits. In your opinion, where are these economic benefits important? 102

Table 5.16. Summary result of respondents' demographics and individual characteristics (survey

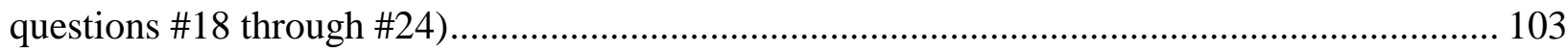

Table 5.17. Summary of education levels of respondents ................................................. 104

Table 6.1. Summary statistics of energy choices made. ..................................................... 107

Table 6.2. Choice trends based on respondents' education level and age .............................. 107

Table 6.3. Definitions of variables included in estimated models ....................................... 111

Table 6.4. Mixed Logit estimation of consumers' choice between electricity generated from

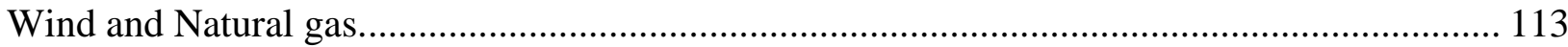

Table 6.5. Unweighted and weighted mean WTP for proximity to wind and natural gas as energy

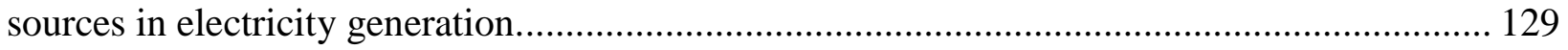

Table 6.6. Mean WTP per month for wind as a renewable electricity generation source relative to natural gas as an alternative electricity generation source 134 Table 6.7. Mean WTP for proximity as an attribute (Grant County sampled population only

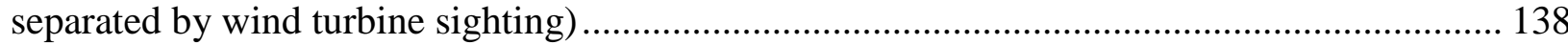
Table 6.8. Mean WTP per month for wind as a renewable electricity generation source relative to natural gas (Grant County sampled population only separated by wind turbine sighting)........ 139 Table 6.9. Aggregate annual WTP for moderate and far away proximity levels. .................... 140 Table 6.10. Aggregate annual WTP for wind energy relative to natural gas.......................... 143 Table 6.11. Aggregate annual WTP per capita for moderate and far away proximity levels..... 144 Table 6.12. Aggregate annual WTP per capita for wind energy relative to natural gas............ 144 Table 6.13. A Logistic model of certainty level ............................................................ 148 Table 6.14. Assessment of choices made vs. opinions on the employment impact of electricity

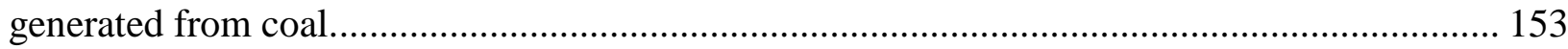

Table 6.15. Multinomial logit models of Grant County and Monongalia County sampled populations assessing Coal Jobs Impact on Choice. 154 


\section{LIST OF FIGURES}

Figure 4.1. Sample choice set presented to respondents ............................................... 73

Figure 5.1. Responses to survey question on average monthly electricity bill........................ 86

Figure 5.2. Respondents age distribution categories. ........................................................ 104

Figure 7.1. United State green pricing participation.................................................... 170 


\section{Chapter 1}

\section{Introduction}

\subsection{Background of Study \& Problem Statement}

Since the industrial revolution began in the late $18^{\text {th }}$ century, fossil fuels have been the primary source of energy in our society. The consumption of fossil fuel as energy in United States has continually increased over the years. The most comprehensive data available shows that the current fossil fuel consumption in United States (2014) has increased about 177\% from consumption levels in 1948 (U.S. Energy Information Administration, 2015c). Energy consumed in the United States is derived from fossil fuels (coal, natural gas, and petroleum), nuclear power, and renewable sources. The U.S. Energy Information Administration (2015c) estimates about 98.30 quadrillion BTUs of energy was consumed by all sectors of the US economy in 2014. During this period, fossil fuels formed the largest share (82\%) of total energy consumed, followed by nuclear power $(8 \%)$ and renewable energy sources $(10 \%)$.

Besides the direct use of energy, the United States Energy Information Administration (U.S. EIA) also estimates about 39\% (38,602 trillion Btus) of the total primary energy consumed in United States was used to generate electricity as an end-use energy. The dominance of fossil fuels as a major source of energy in the United States is also evident in the power sector. Fossil fuels accounted for about $65 \%$ of the total energy used to generate electricity in the United States during the 2014 fiscal year (U.S. Energy Information Administration, 2015c). Over the past six decades, coal as an energy source has continually formed the largest share of electricity generation source in United States (37\% - 57\%). Within the past decade (2004-2014) as alternative sources of energy have become available, the share of coal as an electricity generation source has declined from $50 \%$ 
of the total electricity generated in 2004 to 39\% in 2014 (U.S. Energy Information Administration, 2015d). On the other hand, the share of natural gas as a source for electricity generation in United States has increased from 17\% in 2004 to 27\% in 2014 (U.S. Energy Information Administration, 2015c; U.S. Energy Information Administration, 2015d).

The consumption of electricity in the United States as an end-use product has consistently kept pace with population and economic growth over the last half century. The United States EIA projects electricity demand to grow by $1 \%$ annually between 2012 and 2040 . This represents approximately 29\% growth in demand (U.S. Energy Information Administration, 2015a). The trend in electricity growth has been estimated to slow down over the next few decades.

Electricity from conventional sources which forms the largest share of our society's electricity portfolio is known to create a number of negative externalities. Carbon dioxide $\left(\mathrm{CO}_{2}\right)$, nitrogen oxide $\left(\mathrm{NO}_{\mathrm{x}}\right)$ and sulphur dioxide $\left(\mathrm{SO}_{2}\right)$ emissions have been identified as major externalities associated with fossil fuel electricity generation (European Commission, 2003). These externalities not only affect the environment but also have dire consequences on human health. Invariably, as the power sector continues to rely heavily on fossil fuels, externalities associated with conventional electricity generation will also continue to increase. In general, the connections between these harmful air pollutants, health issues, acid rain and greenhouse effect has heightened the current discussion over the need for alternative energy sources and electricity generation technologies that are environmentally benign relative to fossil fuel sources.

From the economist perspective, efficiency in the current electricity market will only be attained if the value of all externalities are quantified and internalized in the market price of conventional electricity. Yet, as a result of the non-market characteristics of the externalities 
associated with conventional electricity, the current market system is limited in its ability to explicitly internalize these externalities into the total cost of electricity. Over the years, economists have used a number of non-market valuation methods to quantify the value of externalities associated with conventional electricity generation.

A review of the relevant existing literature on electricity externalities shows that what counts as externalities derived from conventional electricity relatively vary among experts of electricity externality estimation. Yet, the general consensus amongst these experts points to the fact that the negative externalities associated with fossil fuel electricity are relatively higher than renewable electricity sources (Sundqvist, 2004).

The value of externalities associated with electricity generation has been assessed in a number of studies over the past few decades using various non-market valuation methods. A review of thirty-eight (38) externality studies published over the past two decades estimated the mean external cost of electricity generated from coal (21.59 cents/kWh), oil (19.71 cents/kWh), and gas ( 7.29 cents $/ \mathrm{kWh})$ to be relatively higher compared to renewable sources. The external costs of renewable energy sources estimated in this study included wind ( 0.42 cents $/ \mathrm{kWh})$, solar (1.0 cents/kWh), biomass (7.55 cents/kWh), and hydro (5.58 cents/kWh) (Sundqvist, 2004). It should be noted that Sundqvist (2004) in his meta-analysis study presented the mean external cost in US dollar (1998). For the purpose of this study, these values have been converted to (2014) US dollars using the average consumer price index for the year 1998 and 2014. 
On average, the retail price of electricity in United States between 1960 and 2014 ranged between 9.0 cent/kwh and 16.0 cents/kWh ${ }^{1}$ (U.S. Energy Information Administration, 2012a; U.S. Energy Information Administration, 2015d). Comparing the average retail price of electricity in United State (1960 - 2014) to the mean external costs of electricity generation presented by Sundqvist (2004), it can be inferred that the average retail electricity price in United States (1940 2014) has been consistently below or comparable to the mean external cost of electricity generated from fossil fuels.

This implies that, even in the presence exiting regulations that have sought to internalize negative externalities that are associated with conventional electricity generation, enormous external costs still exist. In other words, based on the meta-analysis data presented by Sundqvist (2004), existing regulations have not been able to internalize all the externalities associated with electricity generation. Given the enormous negative externalities associated with conventional electricity generation and the inability of the electricity market to internalize these external costs, it can be concluded that current market prices of electricity from fossil fuel sources are way below the true social cost of its production (Borchers, Duke, \& Parsons, 2007; Sundqvist, 2004; Sundqvist \& Söderholm, 2003).

In the past few years, a combination of the high social cost of externalities associated with conventional electricity and the environmental awareness of consumers have become the driving forces of the need to pursue cleaner energy sources to replace fossil fuels in the United States (Bhattacharyya, 2011). In addition, the environmentally benign and socially beneficial attributes of

\footnotetext{
${ }^{1}$ U.S. dollars (2014)
} 
renewable energy sources have made them feasible alternative sources of electricity in our society's quest to limit the external cost derived from conventional electricity sources.

Over the years, there have been conscious efforts primarily driven by policies to invest in clean alternative sources of energy. These policy shifts, both on the federal and state levels, are means of minimizing our dependence on fossil fuels as well as limiting the negative externalities derived from conventional energy sources in the United States. The federal government has yet to pass a comprehensive RPS policy that requires some share of renewable electricity generation in the nation's energy portfolio. Over the past decade, a number of RPS bills have either been proposed at the committee level or been passed in one house but died in another. The most comprehensive RPS bill that showed the slightest sign of being passed in both houses in recent times was the Waxman-Markey Bill 2009. The bill required 6\% of the electricity generated in United States to be generated from renewable sources within the first three years of enforcement and increased to $20 \%$ by the year 2020 . The Waxman-Markey Bill was passed in the house but never came up for vote in the senate (Bochner, 2014).

Currently on the federal level, tax incentives have been the primary policy tool used to drive up the generation capacity and consumption of renewable energy. The earliest most important policy that utilized tax incentives to promote an increase in alternative energy use and energy efficiency in United States can be traced back to the Energy Tax Act of 1978 (Hymel, 2006). The policy provided tax credits to encourage the installation of renewable energy and promote energy efficiency. Both residential and business sectors qualified for these tax credits. In recent years, the most comprehensive energy policy adopted by the federal government is the Energy Policy Act of 2005. Among other requirements on the renewable front, the policy expanded and extended 
(through 2026) the existing Renewable Energy Production Incentive (REPI) which provided tax credits to producers of non-hydro renewable electricity to include landfill gas, livestock methane and ocean energy (Holt \& Glover, 2006).

At the state level, Renewable Portfolio Standards (RPS) have become the driving force of policy shift by states across the country towards increasing the share of renewable energy utilized for electricity generation within their energy portfolios. Over the years, as RPS proliferation continued to grow and the quest for cleaner sources of energy intensified across the country, most States have consistently relied on the expansion of regulations of the power sector as the primary tool to reach their clean energy goals through the use of RPS (Rabe, 2007). The RPS is a policy instrument which mandates electricity utility companies to provide a designated share of electricity from renewable sources in their energy portfolio. These standards have successfully been implemented in a number of states across the country (Rabe, 2007). These portfolio standards, either enforceable by law or just a goal, all have the objective of achieving a clean environment as well as reducing the external cost associated with conventional electricity generation.

The mandates of the various RPS across the country are primarily monitored and enforced by state utility regulatory agencies that oversee the electricity market as a whole. In general, electricity markets are regulated as monopolies at the state level. As of August2015, twenty-nine (29) States and the District of Columbia have adopted an enforceable RPS. Furthermore, eight states have adopted some form of voluntary programs with goals that are not enforceable by law (Database of State Incentives for Renewables and Efficiency, 2015).

Since the inception of the first RPS in Iowa (1983), the generation and consumption of renewable electricity has grown steadily over the years in the United States. An empirical analysis 
of RPS policies in the United States (1998-2006) found a statistically significant positive relationship between an increase in the share of renewable electricity in a State's electricity portfolio and each additional year an RPS is in operation (Carley, 2009). The U.S. EIA estimates the total consumption of renewable energy in United States to be about $10 \%$ of total energy consumed in 2014 (U.S. Energy Information Administration, 2015b).

In terms of electric energy, approximately $13 \%$ of the total electricity generated in United States in 2014 was from renewable sources with the largest share (48\%) emanating from conventional hydroelectric power sources. Although the share of non-hydro renewable electricity (biomass, geothermal, wind, solar, and photovoltaic) continues to be a formidable part of the total renewable electricity portfolio of the United States, electricity from wind has continually been the fastest growing non-hydro renewable electricity source over the past few years (U.S. Energy Information Administration, 2015d). The U.S. EIA forecast the total electricity generated from renewable sources to grow up to $18 \%$ by 2040 . A majority of this growth is attributed to a rapid growth in electricity generated from wind and a consistent contribution from hydro-electricity generation sources (U.S. Energy Information Administration, 2015a). The steady growth in the share of renewable electricity in our total electricity consumption and the optimistic forecast of renewable electricity generation in the future are a result of policy shifts geared towards making renewable energy a realistic source of energy both on the federal and state level.

Even though renewable electricity continues to be an attractive clean source of electricity, it is not totally free from negative externalities. Externalities associated with renewable electricity generation are also predominantly non-market based, and these include a change in air quality, wildlife habitat, and landscape quality (Abbasi \& Abbasi, 2000; Bergmann, Hanley, \& Wright, 2006). 
From the welfare economist perspective, although the negative externalities derived from renewable electricity are minimal relative to conventional electricity, it still presents inefficiency in the electricity market.

If consumers have the option to choose the energy source of the electricity supplied to them in a competitive market, then renewable electricity, like any other product on the market, will be chosen by a consumer only if the attributes and price associated with it in any combination will maximize the consumer's utility relative to the existing conventional sources. Hence, a consumer's awareness of non-market based benefits and limited externalities associated with renewable electricity can influence choices made and cannot be over looked. Given the non-market attributes associated with renewable electricity that are not traded on the market, the current market system used to price electricity is limited in its ability to accurately estimate the true value of renewable electricity.

From the welfare economist perspective, it is necessary to use other economic valuation methods to internalize the true value of externalities associated with renewable electricity into any cost benefit analysis. A quantitative measure of the true social cost of renewable electricity will provide utility regulatory agencies across the country with the empirical basis to make informed decisions on renewable electricity policies in order to maximize social welfare. Such decisions include the kind of renewable electricity source and favorable attributes to pursue in future energy policies. In addition, the true quantitative value of externalities will also provide both the utility regulatory agencies and utility providers with the true value of compensation necessary to address public opposition, if it exist, as well as minimize social cost. 
Moreover, with the high generation cost of renewable electricity relative to conventional sources, renewable electricity market can only be competitive if externalities are internalized into price of renewable electricity (Redlinger, Andersen, Morthorst, \& United Nations Environment Programme, 2002). As Ek (2005) alluded to in his study, the significance of the renewable electricity market depends on how much in extra dollars consumers are willing to pay for green electricity relative to existing conventional electricity. Like any other product on the market, understanding how the attributes of green electricity influence demand, product market share and its relative importance to consumer choice is imperative (Bennett \& Blamey, 2001). In other words, the shift towards voluntary green electricity programs can only be successful if utility providers and state regulatory agencies quantitatively understand the premium consumers are willing to pay for green electricity.

Elicitation of consumers' willingness to pay for green electricity, given their awareness of benefits of green programs can be accomplished using a variety of economic valuation methods including hedonic price modeling, contingent valuation, and choice experiment. An individual's willingness to pay for green electricity includes the monetary value they place on non-market attributes of green electricity. These attributes of interest spans across a variety of physical (eg: size of electricity generation facility, proximity and location) and environmental characteristics (eg: air quality, landscape quality, and wildlife) associated with green electricity.

Generally, as a result of the benign environmental attributes of green electricity, consumers are willing to pay a positive premium for renewable electricity relative to conventional electricity produced using fossil fuels (Bergmann, Hanley, \& Wright, 2006; Borchers, Duke, \& Parsons, 2007; Navrud \& Braten, 2007; Roe, Teisl, Levy, \& Russell, 2001). These premiums can be interpreted as the monetized value of the externalities associated with conventional electricity. Consumers' 
willingness to pay a premium for renewable electricity can also be interpreted as an indication of public approval for policies that seek to expand renewable electricity generation capacity and market as a whole (Ek, 2005).

In spite of the general public approval and positive willingness to pay for renewable electricity, the premium consumers place on renewable electricity has been shown to vary based on attributes of choices available. Given varying attributes of renewable electricity among a choice set, consumers generally have preferences and are willing to pay a higher premium for beneficial attributes relative to attributes perceived to be an externality. On the other hand, disamenities associated with unfavorable attributes of renewable electricity have also been shown to negatively influence consumers' attitude and willingness to pay for green energy programs in general (Bergmann, Hanley, \& Wright, 2006; Farhar, 1999; Roe, et al., 2001; Warren, Lumsden, O'Dowd, \& Birnie, 2005).

Over the years, a substantial number of studies have explored the economic valuation of nonmarket attributes of various renewable electricity sources and externalities associated with it. However, the literature is limited due to a heavy focus on wind. Such a trend is not surprising considering the enormous contribution of wind energy in our current non-hydro renewable electricity portfolio (U.S. Energy Information Administration, 2012a). Furthermore, the capital costs of establishing wind power is relatively lower than other renewable technologies available. Thus, wind power is an economically feasible technology in our society's efforts to expand renewable electricity (Burall, 2004; SPECC \& Culture, 2004).

Wind power has gained a lot of support among proponents of green energy, mostly as a result of its environmental benign attributes. Post construction, wind power is practically free from 
greenhouse gases and other pollutants associated with conventional electricity (Warren, et al., 2005). In spite of its beneficial attributes, wind power like all other forms of energy, is also associated with some level of environmental impacts (Elliott, 2003; Scottish Natural Heritage, 2001). Public perception on wind energy has predominantly been linked to its physical attributes. Devine-Wright (2005) in an extensive review of literature on public perception of wind energy outlined the size of turbines, size of facility, turbine color, geographic location, and proximity as important attributes that have been shown to influence public perception.

Existing literature on externalities associated with wind energy prominently features visual impacts, landscape change, birds mortality and noise as important externalities associated with wind power. Schleisner \& Sieverts Nielsen (1997) in their analysis of external cost associated with various power generation technologies identified noise as an important externality associated with wind energy. Mortality of birds and behavioral changes in wildlife animals has also been linked to wind turbines in operation (Kikuchi, 2008). Landscape change or disamenities associated with wind turbines have also been assessed by a number of studies. Álvarez-Farizo \& Hanley (2002) found a substantial social cost attributable to the landscape changes caused by wind turbines.

Although these externalities generally have a negative influence on a consumer's choice, attitude, and willingness to pay for wind power, the level of impact varies based on the consumer's geographic location (sampling location) (Khan, 2003; Krueger, Parsons, \& Firestone, 2011; Ladenburg \& Dubgaard, 2007; Redlinger, et al., 2002).

There is an intrinsic relationship between public approval, attitudes, willingness to pay and size of the market for green energy programs. As a result, a fair share of the studies that have assessed a consumer's preference for wind power have focused primarily on consumer attitude towards wind 
power. Most of these studies have sought to address how such attitude towards a wind farm project varies as important physical attributes of the projects are varied. One of the most important attributes of wind power that has been the center of existing literature on consumer's attitude and preferences is proximity as an attribute of wind farms. Most of the existing literature on this attribute of wind power has largely sought to test the proximity hypothesis (Braunholtz, 2003; Devine-Wright, 2005; Van der Horst, 2007; Warren, et al., 2005). The proximity hypothesis generally states that as a result of perceived potential externalities, consumers will be more likely to oppose an unwanted facility depending on how close they are to the facility (Dear, 1992).

Even though the proximity hypothesis with respect to wind farms has generally been found to be valid, a handful of studies have also shown that the hypothesis cannot be generalized in all scenarios of evaluating consumers' attitude towards a wind farm. Moreover, consumer's attitude and willingness to pay for wind power has been shown to be dependent on other factors beyond just the physical attributes in question. The stage of the facility development, perceived externality over time and value of the land are some of the important factors that have been shown to influence consumers' attitudes in conjunction with the physical attributes of a renewable electricity facility. In addition, a consumer's attitude towards a wind power facility has been shown to be dependent on whether the facility in question is a hypothetically proposed facility or it already exists (Van der Horst, 2007; Warren, et al., 2005).

Prior to a wind facility development, consumers living in close proximity to a proposed wind farm generally exhibit a negative attitude towards wind power compared to consumers with residence that are farther away. Hence, consumers' attitude generally represents a classical "Not in my back yard effect" (NIMBY) and validates the proximity hypothesis (Warren, et al., 2005). On the contrary, consumers exhibit an inverse effect of "Place in my back yard effect" (PIMBY) if the 
facility in question already exists because as time progresses individuals realize that the perceived external cost present is lower than previously thought (Braunholtz, 2003; Warren, et al., 2005). Interestingly, a recent study of consumers' attitude towards wind farms in Texas found contrasting results where the highest unfavorable attitude towards an existing wind farm was within individuals that lived in close proximity to the facility relative to those that live farther away (Swofford \& Slattery, 2010).

In term of consumers' willingness to pay for proximity as an attribute of wind turbines, existing literature generally has validated the proximity hypothesis. There exists an inverse relationship between consumers' willingness to pay for wind power and consumer's close proximity to a proposed wind farm (Krueger, Parsons, \& Firestone, 2011; Ladenburg \& Dubgaard, 2007). Navrud \& Braten (2007) also showed that individuals whose residences were at a sampled location that had an existing wind farm have a lower monetary values for wind power and its attributes relative to individuals sampled at a location with no such existing facility.

In summary, the influence of proximity and location as attributes of wind power on consumers WTP largely confirms the NIMBY concept of the proximity hypothesis. Yet, Groothuis, Groothuis, \& Whitehead (2008) presented a contrasting result in their study which showed that consumers with genuine environmental concerns were willing to accept (WTA) less compensation to site a wind farm in their neighborhood. In the midst of all these conflicting results on consumers' attitude and WTP for green energy, especially wind, economists do agree that, on aggregate, location of a consumer and proximity as an attribute of renewable energy matters when assessing WTP for green electricity. The nature, strength and spatial scale at which they influence consumers WTP and attitudes may depend on the local context, physical (land value) and social settings (Swofford \& Slattery, 2010; Van der Horst, 2007). 
Even though a number of studies exist on the impact of an individual's location and proximity as an attribute of wind power in the literature of renewable electricity, only a few of these studies have explicitly examined these two factors on consumers' willingness to pay for renewable electricity (Krueger, Parsons, \& Firestone, 2011; Ladenburg \& Dubgaard, 2007; Ladenburg \& Dubgaard, 2009; Navrud \& Braten, 2007). Largely missing in the current body of literature is a comprehensive study of the effect of consumer's location, proximity and other physical attributes of electricity generation on consumers' WTP for other renewable electricity sources besides wind.

Currently, literature that exists on the monetary value of benefits and disamenities derived from physical attributes of other renewable electricity sources beside wind is sparse (Navrud \& Braten, 2007). With the rapid advancement of renewable electricity technologies, it's evident that our society will not only continue to rely on wind power in the near future but aggressively pursue other renewable sources including solar, geothermal and biomass as they become economically feasible. As a result, it's important that future studies on consumers' attitudes and willingness to pay for renewable electricity also assess the disamenities derived from the attributes of non-wind energy resources and the associated social costs associated with it.

Furthermore, the effect of a consumer's residential location relative to an existing electricity generation facility on the consumer's WTP for a newly proposed, renewable electricity facility has been scantly explored. In an extensive literature review for this study, only two studies attempted to explicitly determine how an existing renewable electricity facility in close proximity to a consumer's residential location influenced her/his WTP a premium for a proposed renewable electricity generation facility (Ladenburg \& Dubgaard, 2007; Navrud \& Braten, 2007).

In view of the varying effects of consumer location and proximity as an attribute of renewable electricity on consumers' willingness to pay, it's important to continually add to the limited body of 
literature on how these attributes influence consumers' willingness to pay. A comprehensive and comparative study of how locational factors influence consumers' WTP as well as attitudes towards other renewable electricity sources besides wind power is important. In the era of enforceable renewable portfolio standards with varying goals and targets in states across the country, utility regulatory agencies will find such a study useful in any cost benefit analysis of renewable energy electricity policies. This study seeks to address this issue in West Virginia; a state with an enormous natural gas resource and the potential to utilize it as an electricity generation source.

As a number of states across the country deregulate their retail electricity markets, West Virginia remains one of the many states that still maintain a monopolized regulated market. As of 2010, only 17 states and the District of Columbia had a fully restructured retail electricity market that allows consumers to choice an electricity retail supplier in a competitive market environment (U.S. Energy Information Administration, 2010b). Almost $60 \%$ of the total retail electricity in United States was supplied competitively in 2010 (U.S. Energy Information Administration, 2010b). West Virginia as a state assessed the cost and benefits of a completive retail market in the late 1990s but never implemented the recommendations of a task force that was mandated to investigate the merits of deregulation. In fact, the PSC in a response to proposals submitted by proponents of restructuring stated that; "The Staff of the Public Service Commission of West Virginia remains unconvinced that the theoretical benefits of a deregulated power supply market are so absolute or all encompassing, that they will automatically benefit even a majority of, let alone all, West Virginian electricity users. In fact we are concerned that the potential detriments of creating a deregulated power supply market outweigh the potential benefits" (CASE NO. 98-0452-E-GI). 
As a result of the regulated monopolized market structure that currently exists, electricity consumers in West Virginia do not have a choice amongst alternative electricity generation sources or utility providers. Although a competitive electricity market does not exist in West Virginia, it does not preclude us from investigating the role proximity and location plays in consumers' choice of renewable electricity. Even if a competitive electricity market existed, it does not imply consumers get to explicitly choose the location and proximity of preferred electricity generation source. States with competition within electricity markets across the country only allow consumers the choice between electricity generators. This often includes both renewable and non-renewable sources of energy. Because consumer choice of electricity provider does not exist in West Virginia, this study will also utilize a non-market valuation method to elicit consumer's preference and estimate their willingness to pay for renewable electricity in the state.

In 2009, the state of West Virginia adopted the Alternative and Renewable Portfolio Act (ARPS). The policy required at least $10 \%$ of electricity supplied to consumers to be supplied from renewable and alternatives sources by 2015. Beside the typical sources of renewable energy, a variety of non-renewable source of energy and renewable credit trading within the PJM market qualified under the policy. In an unusual move, the state legislature repealed (HB 2001) the ARPS policy before it could take effect. Opponents of the policy cited potential burden on consumers in a form of an increase in consumer's electricity bill, negative impacts on coal related jobs and the general unpopularity of the policy among residents of the state (West Virginia Chamber of Commerce \& West Virginia Business Industry Council, 2015).

To the best of my knowledge, none of these claims were supported by a relevant study or data that proved these concerns. As West Virginia struggles to find a balance between energy 
dependence, protection of coal related jobs and environmental impacts related to the over dependence of fossil fuels; this study seeks to answer some of the questions raised during the debate on the ARPS repeal. It should be noted that this study was designed and modeled after the ARPS 2009 bill with the assumption that it was going to enforced in 2015. As a result, this study may not provide all the required answers needed to assess whether a repeal of the ARPS policy was justified or not.

\subsection{Study Area}

West Virginia, a state with a vast deposit of coal, accounts for about $12 \%$ of the total coal production in United States in 2012 (U.S. Energy Information Administration, 2015e). In 2013, total coal production in West Virginia was the second largest $(112,786$ short tons) in the country behind Wyoming (U.S. Energy Information Administration, 2015e). In terms of estimated recoverable coal reserves, West Virginia was ranked $4^{\text {th }}$ in the country with an estimated 1,714 million short tons of coal reserves (U.S. Energy Information Administration, 2015e). The U.S. EIA estimates the total electricity generated in West Virginia (2012) to be about 73 million megawatt hours (MWh) (U.S. Energy Information Administration, 2012b). Current estimates (2014) put the share of total electricity generated from coal in West Virginia at approximately $95.5 \%$ (U.S. Energy Information Administration, 2012b). Based on specific fuel sources (2012), electricity (total electric industry) generated from coal-fired facilities formed the largest share with total output estimated at 70 million MWh (95.7\%), while natural gas and petroleum together contributed a meager 386 thousand MWh (0.5)\% of the total electricity generated during this period (U.S. Energy Information Administration, 2012b). 
West Virginia, like many states across the country, also has some installed capacity of renewable electricity which predominantly includes conventional hydroelectric and wind sources. The most current data available (2012) estimates the electricity generated from hydro and wind sources respectively contributed about 1.7\% (1.9 million $\mathrm{MWh}$ ) and 1.8\% (1.3 million MWh) of the total electricity generated in West Virginia (U.S. Energy Information Administration, 2012b). In all, a total of thirty-three (33) electricity generation facilities are online in the state. These facilities are scattered across nineteen (19) counties. These include coal-fired facilities (17), natural gas-fired plants (4), hydro plants (10), and wind farms (3). Moreover, a biomass-fired facility with a potential generation capacity of $(28 \mathrm{MW})$ and three wind farms projects with combined potential generation capacities of (370MW) have received operational permits from the West Virginia PSC (U.S. Environmental Protection Agency, 2014; West Virginia Department of Commerce, 2012).

Primarily as a result of the enormous dependence on coal as the major energy source, West Virginia is ranked as the 11 th most $\mathrm{CO}_{2}$ emitting state with a total of 67,203 thousand metric tons as of 2012. In addition, the state was ranked 14 th and $21^{\text {st }}$ in the total emissions of sulfur dioxide and nitrogen oxide, respectively. All these environmentally harmful gases are direct by-products of combustion from coal-fired electricity generation (U.S. Energy Information Administration, 2012b). Like many other states across the country, West Virginia in 2009 sought to limit the environmental and health externalities associated with conventional electricity generation through the use of an alternative and renewable energy portfolio standard (ARPS). With this policy, the Public Service Commission sought to reduce harmful gas emissions associated with electricity generated from coal, expand the economic base of the state, and also make the state competitive in attracting new business ("Alternative and Renewable Energy Portfolio Act.," 2009). 
The RPS of West Virginia required investor-owned utilities and retail suppliers with more than thirty thousand $(30,000)$ customers to produce at least $10 \%$ of their total electricity supplied from energy sources eligible under the policy between 2015 and 2019. By January 2025, the policy required investor-owned utilities and retail suppliers of electricity to generate at least $25 \%$ of the total electricity supplied in the state from energy sources eligible under the policy (Database of State Incentives for Renewables and Efficiency, 2012). Renewable energy sources that were eligible under the policy included solar thermal electric, photovoltaics, landfill gas, wind, biomass, hydroelectric, geothermal electric, fuel cells, and municipal solid waste.

West Virginia's alternative energy policy is unique relative to other RPS enacted cross the country because it includes the possibility of using alternative eligible energy sources to meet the goals of the policy. The alternative energy sources eligible under the policy include clean coal technology, coal bed methane, natural gas, fuel produced by a coal gasification or liquefaction, synthetic gas, integrated gasification combined cycle technologies, waste coal, tire-derived fuel, pumped storage hydroelectric projects, and recycled energy (Database of State Incentives for Renewables and Efficiency, 2012). Moreover, tradable permits of renewable credits trading both within state and between utility companies within the PJM market was also permissible under the policy (Database of State Incentives for Renewables and Efficiency, 2012). As of 2013, Michigan, Ohio and Pennsylvania are among the few states that have also included non-renewable (alternative) energy into their RPS policy (Heeter \& Bird, 2013).

In an unusual move, West Virginia repealed its ARPS policy in 2015. Legislator and opponents of the policy cited numerous reasons why a repeal of the laws was necessary. To date, West Virginia is the only state that has successfully passed an ARPS policy and repealed it before it took effect. Even though assessing the validity of a repeal of the policy was never a focus of this study, 
we hope the result will shed some insight on a number of concerns raised during the repeal process.

According to the United States EIA, the average levelized cost of renewable electricity technologies (wind, biomass, solar and hydro) that were projected to be online in 2016 will generate electricity at a higher cost relative to fossil fuels (conventional coal and natural gas) (U.S. Energy Information Administration, 2010a)². As a result, all things being equal, an individual's choice of green electricity implies his willingness to pay a positive premium for green electricity relative to cost of conventional electricity. For a policy like an RPS to be sustainable in the long term, the benign environmental cost associated with electricity generated from renewable energy relative to fossil fuels needs to be sold to consumers who will eventually have to pay a positive premium relative to the current price of conventional electricity. The lower external cost associated with electricity generated renewable electricity relative to fossil fuels if recognized and understood by consumer will ensure support and sustainability of the RPS policy.

An acceptable positive premium that can placed on the provision of renewable electricity by utility providers will have to be approximately equal to consumers' willingness to pay for green electricity. Such a premium can be interpreted as the monetary value consumers place on the preferred environmentally benign attributes of renewable electricity.

West Virginia presented an interesting case study for this research because at the time this research commenced (2013) the adopted RPS was yet to take effect in 2015. Moreover, no literature has explored consumers' preference, willingness to pay for renewable electricity and

\footnotetext{
${ }^{2}$ The U.S. EIA levelized cost is an average levelized cost (2008 \$/Mwh) for plants entering service in 2016.
} 
factors that influence demand for renewable electricity in West Virginia. Hence, this study area gives us the opportunity to investigate these important aspects of consumers' demand for green electricity and its resulting welfare changes for the very first time.

West Virginia also has interesting characteristics as a potential study area for this research which focuses on the effects of location and proximity as an attribute of electricity generation on consumers WTP for cleaner source of electricity. West Virginia currently has existing renewable electricity facilities and numerous coal-fired facilities in varying geographic locations within the state. Moreover, the enormous biomass and natural gas resource available within the State makes the potential expansion of the State's electricity portfolio to include electricity generation from natural gas in the near future inevitable.

Currently, a newly proposed natural gas-fired power plant by Moundsville Power has cleared siting hurdles and has been issued a siting certificate (Case No. 14-1221-E-CS) by the public service commission to build a 549 MW capacity power plant in Moundsville, WV (Marshall County). The proposed plant is expected to be online by August 2018. Energy Solutions Consortium, the same consortium behind the Moundsville power plant project, has proposed three additional natural gasfired power plants to be built in Brooke County and Harrison County pending negotiations with both county commissions. In the meantime, a memorandum of understanding for the proposed projects have been signed between Energy Solutions Consortium and the two county commissions.

These potential additions to the electricity portfolio in West Virginia presents an opportunity to include other cleaner sources of electricity generation besides wind in this study. Hence, the inclusion of wind farms and natural gas-fired power plants in this study are not based on hypothetical assumptions but on the evidence that these facilities already exist or have been 
approved to be constructed in West Virginia by the PSC. West Virginia also provides this study the opportunity to be able to sample populations with varying residential location characteristics in relation to current existing renewable and non-renewable electricity generation facilities. Such a sampling technique will be used to address the influence of location as an attribute of renewable and alternative electricity generation on consumers' WTP.

According to the U.S. EIA, West Virginia exported more than half (56\%) of the total electricity generated in the State (39 million MWh) as net interstate trade in 2012 (U.S. Energy Information Administration, 2012b). As a result, although most of the externalities associated with electricity generation, especially those that alter the immediate surrounding landscape immensely affect local residents of West Virginia out of state consumers of power generated from West Virginia hardly experience these disamenities. Over the years, as the debate over green energy has progressed, it has widely been accepted that the motivation and benefits from the push towards green energy are globally shared (climate change) and spatially diffused in the long term. On the other hand, externalities associated with green energy are localized, immediate, and highly visible (Warren, et al., 2005).

As West Virginia continues to export a large share of its electricity out of state and struggles to find a path towards modern society's push towards green electricity, the state as a study area present this research the opportunity to explore the spatial effect (location \& proximity) of externalities associated with renewable and alternative electricity generation on consumers choice and willingness to pay for green and alternative electricity. The results of this study, we hope, will provide the Public Service Commission and utility companies in West Virginia with credible 
information about consumers' demand, willingness to pay, and factors that influence demand for cleaner sources of electricity generation relative to coal.

\subsection{Objectives of Study}

As the state government of West Virginia struggles to find the right path to expand its renewable energy portfolio, public acceptance of renewable and/or alternative electricity and willingness to pay a premium for these electricity generation sources are crucial to establishing viable markets for these forms of energy. This study attempts to addresses these issues in West Virginia. The overall objectives of this study are:

(a) To assess consumers' attitudes, preferences, and demands for renewable and alternative electricity in West Virginia.

(b) To assess how proximity as an attribute of electricity generating sources (renewable and alternative) impacts a consumer's choice and willingness to pay for electricity generated from either wind or natural gas.

In order to achieve these broad objectives this study also has the following goals:

(1) Determine consumers' preferences and attitudes towards renewable and alternative electricity in West Virginia.

(2) Estimate the monetary value consumers place on renewable electricity and alternative electricity.

(3) Estimate the monetary value consumers place on proximity as an attribute of renewable electricity and alternative electricity generation sources.

(4) Compare the preferences and WTP for green electricity and its attributes for the sampled populations from Grant and Monongalia County residents (location comparison). 
Most literature on the non-market valuation of renewable electricity has focused on either just wind as an energy source or renewable electricity as a generic source of electricity. This study will include both wind and natural gas as sources of electricity generation. It will be among the few studies that have attempted to evaluate consumers' willingness to pay for other relatively cleaner sources of electricity besides wind (Borchers, Duke, \& Parsons, 2007; Navrud \& Braten, 2007). 


\subsection{Research Questions}

The most important research questions that this study seeks to answer in West Virginia are:

1. Do residents of West Virginia, a state with so much history with coal and coal related jobs, have preferences for electricity generated from cleaner sources of energy relative to coal?

2. What are the attitudes of West Virginia residents towards cleaner sources of electricity generation?

3. If consumers of electricity in West Virginia are forced to choose between supplying $10 \%$ of their electricity from wind and natural gas sources, what option will they choose and what factors explain these choices?

4. Are residents of West Virginia willing to pay a premium for electricity generated from wind relative to natural gas?

5. Do residents of West Virginia value proximity of their current residence to a newly sited electricity generation facility (wind or natural gas)?

6. Does where you live in the state (current location or county) influence the monetary value you place on electricity generated from wind or natural gas and proximity as an attribute of the generation source? 


\section{Chapter 2}

\section{Literature Review}

\subsection{Elicitation of Value placed on Green Energy Attributes}

The enormous external costs associated with electricity generated from fossil fuel sources create a need to pursue green energy programs with minimal external costs. The success of any voluntary green energy program, as an alternative to electricity derived from fossil fuels, will depend on consumers' willingness to pay (WTP) a positive premium for green energy. Renewable electricity has both monetary and non-monetary attributes.

The limitations of the current energy market in accounting for the full social costs of electricity generation and other non-market attributes considered in an individual's utility function undervalues how much consumers are willing to pay for renewable electricity. The value that individuals place on renewable electricity depends upon the favorable attributes of green electricity. The most important attributes of interest that impact consumers' WTP are the environmentally benign attributes of renewable electricity relative to electricity generated from fossil fuels, mainly coal. These attributes include improved air quality and minimal environmental pollution. Since the market system relies on consumer's preference through buying and selling activities in the market sector, the true value of consumers' WTP for beneficial environmentally related attributes and other green energy characteristics can only be elicited using non-market valuation methods (Bennett \& Blamey, 2001).

Over the years, non-market economic valuation methods have been used to elicit consumers' WTP for green programs. These methods include; (1) revealed preference approach (indirect) and (2) stated preference approach (direct). The revealed preference approach 
estimates the value of a non-market good by observing the choice behavior of a consumer towards a closely related market commodity. The most common non-market valuation methods that utilize the reveal preference approach are the travel cost method and the hedonic price modeling method (Bennett, 1996; Perman, 2003). Roe, et al. (2001) successfully used the hedonic method to assess factors that influence consumers' WTP for green electricity in existing green markets across the county (Maine, Connecticut, New Jersey, Pennsylvania and California). The study sought to explain how factors such as green certification, new generation source, green power company (supplier), and percentage of renewable fuel mix, and current state of residence (market) to explain the annual premiums consumers pay for green power.

The stated preference method has enjoyed high patronage among environmental economists in order to measure consumers' WTP for green energy programs. This method is used to estimate a value a consumer places on an environmental good by asking the consumer to state his or her preference for a hypothetical good in a hypothetical market place. There are a number of different techniques that fall under stated preference methods. These include the contingent valuation method (CVM), choice experiment (CE) and conjoint analysis (CA). Over the years, the most commonly used direct approach technique in environmental valuation has been the CVM. This method estimates the value of environmental attributes by asking consumers about their WTP or willingness to accept (WTA) compensation for a hypothetical scenario that combines different levels of environmental services or goods of interest (Bennett \& Blamey, 2001; Perman, 2003).

Even though the CVM has been used more often in environmental valuation than any other direct approach method, its validity has been questioned (Hanemann, 1994). Wiser (2007) successfully used CVM to assess the effects of payment vehicle on consumers' WTP for renewable energy. More recently, a number of studies have used choice experiments to value consumers' WTP 
for environmental goods and services. The choice experiment approach estimates the value of a non-market good by asking consumers to choose among alternatives with varying levels of attribute combinations. The variation and combination of attributes of interest are done systematically and a monetary value is always included as one of the attributes. This allows researchers to estimate the tradeoff consumers make in order to gain more or less of a nonmonetary attribute (Alpizar, Carlsson, \& Martinsson, 2001).

All things being equal a rational consumer will maximize the utility derived from a choice among alternatives presented in a choice set by choosing the option with the most desirable attributes. The concept of choice experiment is based purely on an extension of Lancaster (1966), which asserts that a bundle of characteristics and attributes of a commodity are the features that are of interest to a consumer when making choices. The probability of making a choice can be estimated and modeled in terms of the attributes associated with the option in a dichotomous modeling platform. The CE approach has been found to be useful in predicting the market share of a new product or variation of an existing product market being considered (Louviere \& Woodworth, 1983). It has also been found to be useful as a decision tool in the allocation of a good that does not have an existing market such as air quality (Bennett \& Blamey, 2001).

\subsection{Consumers WTP for Environmental and Non Environmental attributes}

Previous studies have estimated consumers' WTP for green energy by varying desirable attributes and characteristics. Using conjoint analysis and hedonic method, Roe et al (2001) estimated individuals' WTP for changes in environmental attributes associated with green programs by varying the levels of air pollution emissions that will be possible for each choice presented in the choice set. The result of this study suggested that consumers are willing to pay a 
median value that ranged between $\$ 0.11$ to $\$ 14.22$ per year for a one percent increase in renewable energy and a one percent decrease in emissions. Even though the median WTP was high and statistically significant for the substitution of fossil fuel energy with renewable energy, consumers desired clean air even without any increase in renewable energy fuel mix. For a one percent decrease in emission without altering the fuel mix quantities (no change in renewable energy), consumers showed a median WTP that ranged between $\$ 0.38$ and $\$ 5.66$ per year. Nuclear energy, as part of the fuel mix, was included in the choice set and consumers exhibited positive median WTP for nuclear power with a median range of $\$-1.03$ to $\$ 14.43$ per year. This result shows that consumers prefer an energy source that emits fewer pollutants into the environment.

Similarly, Bergmann et al. (2007) used the CE approach to assess consumers' WTP for environmental attributes of renewable energy. Attributes of renewable energy that may impact alternative forms of renewable energy investment were investigated in this study. These attributes included landscape, wildlife and air pollution attributes. The results from this study showed that individuals placed a higher positive premium on renewable investments that were associated with minimal environmental impacts. The variation between households' WTP a premium per year for a large offshore wind farm (£6.60) versus a large onshore wind farm $(-£ 19.40)$ was enormous.

Bergmann et al. (2007) attributed this enormous variation in consumers' WTP for an offshore versus onshore wind farm to household's preferences towards an energy source that has minimal impact on desirable attributes such as landscape, wildlife, and air pollution. Individuals exhibited a very high WTP towards renewable energy investment with no air pollution ( $€ 14.40 / y r)$ and improved wildlife attributes $(£ 10.11 / \mathrm{yr})$. On average, households sampled in the study were also willing to pay positive premiums for landscape impact and employment impact attributes of renewable energy. Both studies by Roe et al, (2001) and Bergmann et al. (2007) support the 
economic theory that consumers place high value on environmental attributes of green energy and prefer green energy programs that minimize environmental externalities.

Even though Roe et al. (2001) showed that consumers are willing to pay a positive premium for a renewable energy mix that has desirable environmental attributes, these authors failed to explicitly estimate consumers' WTP for a specific renewable energy source. Different types of renewable energy sources have different environmental attributes. Hence, it is logical to assume that if consumers prefer a decrease in air pollution from energy production, they will most likely prefer a renewable source that has the potential to increase clean air and reduce other environmental externalities.

Using a choice experiment approach and a nested logit model, Borchers et al. (2007) investigated differences in consumers' WTP given different types of renewable energy. Five renewable energy sources (generic green energy, solar, wind, biomass, and farm-methane) were considered in this study. The null hypothesis that generic green energy provides the same utility to consumers as solar, biomass, and farm methane was rejected. The impact of wind energy and generic energy on consumers' utility could not be statistically distinguished from each other. Only solar energy had a positive coefficient in the utility model. This implied that, all things being equal, the utility derived from solar energy was much higher than all other green energy source.

Borchers et al. (2007) found that the mean WTP was highest in a voluntary program that provided $25 \%$ of the household's electricity from renewable sources. Under these specified levels of attribute for a voluntary green energy program, consumers' mean WTP a premium for green energy were highest for renewable energy generated from solar energy $(\$ 21.54 /$ month $)$ and a generic green energy ( $\$ 17.00 /$ month). The mean WTP for wind, biomass, and farm methane green energy 
programs were between ( $\$ 15.47 /$ month) and ( $\$ 10.59 /$ month). Consequently, we can deduce form these results that, all things being equal consumers have a positive WTP for green energy programs relative to the status quo and perceive solar energy to increase their utility more than any other source of renewable energy. Therefore, specifying the source of renewable energy in a renewable energy program offered to consumers will have varying impacts on consumers' utility and WTP for the program.

A similar result was found by Navrud et al. (2007) in a study of Danish consumers' WTP for cleaner sources of electricity relative to coal. This study showed that, on average, consumers were willing to pay a higher premium for electricity generated from wind compared to natural gas and hydropower. Navrud et al. (2007) concluded that consumer's perceived wind energy to be more environmentally friendly than hydropower which requires alteration of aquatic systems due to dams.

Other attributes of renewable energy have been found to influence households' WTP a premium for renewable energy. These attributes include: size of the renewable generation facility and payment vehicle of the green program. Navrud et al. (2007) also investigated consumers' WTP for size (few large plants, more medium plants and many small plants) of the facility as an attribute of renewable electricity generation. This study found that, on average, households were willing to accept a higher compensation for the "many small" facilities (-NOK 519.84) as compared to "more medium" facilities (-NOK 388.55) all relative to the base case of "few large" power plants. This implied that consumers preferred concentrating visual disamenities of electricity generation at a single location. 
Borchers et al. (2007) also investigated variations in consumers' WTP for green programs as a result of difference in payment vehicle of a green energy program. This study showed that on average consumers' WTP for a generic green energy source in a voluntary program would decrease by $43 \%$ per month when a non-voluntary program was implemented. The authors of this study attributed the decrease in mean WTP for the non-voluntary program to the mandatory requirement to choose a green program at a fixed cost that does not necessarily maximize all respondents' utility.

Wiser (2007), presented a contrasting view of payment vehicle effect on households' WTP for renewable energy programs. This study compared a collective payment renewable energy program with a voluntary payment program using the contingent valuation (CV) approach. Respondents' mean WTP for renewable energy was higher under the collective payment method compared to the voluntary payment method. Wiser (2007) attributed this variation in WTP for a renewable energy program to free riding or strategic behavioral responses of survey respondents towards a voluntary payment programs.

\subsection{Willingness to Pay and an Individual's Social Characteristics}

In almost all non-market valuation of environmental attributes studies including those discussed in the sections above, socioeconomic and demographic characteristics of respondents have been found to influence the mean WTP for green energy. For example, low income respondents have a lower WTP for attributes of green energy compared to high income respondents (Borchers, Duke, \& Parsons, 2007). On average, urban residents have a higher WTP for electricity generated from wind compared to rural residents. Rural residents also valued wildlife and reduction in air pollution levels more than urban dwellers. Respondents' education 
level is also positively correlated with WTP for green programs. Respondents with college degree exhibited a higher WTP for green energy compared to respondents with high school diploma and no high school diploma (Borchers, Duke, \& Parsons, 2007; Navrud \& Braten, 2007; Roe, et al., 2001). Other demographic characteristics such as age, sex and environmental group affiliation were also investigated in these studies and the impact on WTP for green programs if present were minimal (Borchers, Duke, \& Parsons, 2007; Navrud \& Braten, 2007; Roe, et al., 2001) .

\subsection{Consumers Preference and Attitude towards Green Energy}

Over the years, studies have found that public attitudes towards renewable energy are very positive (Krohn \& Damborg, 1999). In a survey of literature on public preferences for green energy in United States between 1979 and 1992, Farhar and Houston (1996) found that as a result of continual environmental concerns over the years, individuals consistently exhibited a higher preference for renewable energy and energy efficiency relative to fossil fuel source when price or cost are not considered. Also in a national study of consumers' preferences for renewable energy in United States, $47 \%$ of the adult respondents believed that renewable energy should be given the highest priority in any government funded research on energy, compared to only $7 \%$ for fossil fuel source (Breglio \& Sustainable Energy Budget Coalition, 1994).

Consumers' preferences for renewable energy relative to fossil fuels have also been evident in a number of studies that sought consumer choice among alternative energy sources. Brotchers et al. (2007) in a study on consumers' WTP for renewable energy sources showed that given the choice between a fossil fuel status quo energy source and a green energy program, only $39 \%$ of the respondents preferred the status quo source over the green energy program. Similarly, individuals surveyed in a comprehensive study in Scotland showed an overwhelming support for renewable energy (wind and wave energy) relative to fossil fuel sources (Braunholtz, 2003). Studies that have been conducted over the years to 
assess consumers' attitudes towards wind energy have consistently found that consumers generally have a positive attitude towards wind energy relative to fossil fuels (Braunholtz, 2003; Devine-Wright, 2005; Krohn \& Damborg, 1999; Warren, et al., 2005). It should be noted that the vast majority of consumer preference studies on renewable energy have only focused on wind energy as an energy source.

\subsection{The Proximity Hypothesis and Consumers' Attitude towards Green Energy}

The proximity hypothesis generally have been connected to NIMBY conflicts. The hypothesis states that, consumers or residents are who live closer to an unwanted facility are more likely to oppose the facility (Dear, 1992). A number of studies have attempted to investigate the spatial aspects of green energy programs and its impact on consumers' attitudes towards green programs. Most of these studies have been done using the proximity hypothesis. Results from these studies have been mixed (Devine-Wright, 2005). Yet, the role that proximity plays in consumer attitudes and perceptions in relation to green energy, especially wind farms, cannot be overlooked The differences in consumer attitudes towards green energy as depicted in a number of studies may be a result of the local characteristics of the location being studied (Van der Horst, 2007).

In a study on public attitudes toward wind farms in Scotland, Braunholtz (2003) found some level of inverse relationship between the frequency of seeing a wind facility from a variety of locations presented to consumers and positive attitude towards the impact of wind on the local area. In order to assess residents attitudes towards wind farms and how it varies with proximity to the facility, the study sampled respondents based on the proximity of their residence to an existing wind farm. The results showed that a higher percentage of the respondents (44\%) who lived closer (with $5 \mathrm{~km}$ ) to the facility believed that the facility had a positive impact on the local area compared to $16 \%$ of the population who lived $10-20 \mathrm{~km}$ away from the facility (Braunholtz, 2003). This 
inverse relationship between the proximity of individuals' residence to a wind farm and attitude towards the facility has also been confirmed in a number of studies that have assessed public attitudes (Thayer \& Freeman, 1987; Warren, et al., 2005).

Using a similar methodology, Warren et al. (2005) examined public perception of wind power in Scotland. They found a stronger support (91\%) for wind farm technology among individuals who lived $0-5 \mathrm{~km}$ (inner zone of study area) from the facility compared to $86 \%$ of the surveyed population who lived within the outer zone of $5-10 \mathrm{~km}$ away from the wind farm. Consistent with earlier studies, opposition towards the wind farm was greater in the outer zone $(10 \%)$ compared to the inner zone $(6 \%)$ of the surveyed area.

A contrasting result that upheld the proximity hypothesis was recently presented by Swafford et al. (2010) in a study of public attitude towards an existing wind farm in Texas. Using a three zone demarcation methodology within a 20 kilometer radius from a wind farm $(0-5 \mathrm{~km}, 5$ $10 \mathrm{~km}$, and $10-20 \mathrm{~km}$ ), the study found a strong negative attitude towards wind energy among residents that lived within the inner zone of $0-5 \mathrm{~km}(37.5 \%)$ compared to those surveyed within the outer zones of 10-20km (10.6\%). Apparently, respondents' positive attitude towards wind energy increased as you move farther away from the inner zone of $0-5 \mathrm{~km}(37.5 \%)$ to the outer zones (71.7\%).

Swafford et al. (2010) also found that, within the surveyed sampled population, support for the wind farm increased as the distance of the facility to respondents' residences increased. Individuals in close proximity $(0-5 \mathrm{~km})$ to the facility were less likely to support wind farms $(28.6 \%)$ on their property compared to those who lived within the outer zones beyond $10 \mathrm{~km}(56 \%)$. The percentage of respondents who did not support wind facility were fairly equal (13.8-14.3\%) in all 
three proximity zones surveyed. In comparing their study to other studies that have assessed proximity as an attribute of a wind facility and individual's attitudes, Swafford et al. (2010) attributed the contrasting results they found to other factors that may be influencing respondents' attitudes beyond just proximity as a physical attribute of a wind facility. These factors include the environmental literacy of the public and public participation (engagement) in decision making related to the project.

In terms of public perceptions towards a proposed green energy facility, individuals' attitudes towards a proposed wind facility have been found to be consistent with the proximity hypothesis. Using the three zone methodology, Warren et al. (2005) again found support for a proposed wind farm to be much greater among individuals surveyed within the outer zone, whereas opposition was greater among individuals surveyed within the inner zone of a proposed wind farm location (permit approved) in Scotland.

On the other hand, a number of studies on respondents' attitudes and the proximity hypothesis, especially on wind energy, also supports the theory that an inverse relationship exists between respondents' attitudes and the proximity of their residences to the facility. This phenomenon is popularly referred to as the "inverse not in my back yard" (Inverse-NIMBY) effect. The inverse-NIMBY phenomenon exhibited by consumers has been mainly attributed to the decay of negative perception towards the facility from its proposed stage to operational stage. The opposition to a proposed facility may be an exaggeration of negative perception and fears of potential impacts. As the facility goes into an operational stage, individuals become well-informed and such misconceptions decay over time (Braunholtz, 2003; Devine-Wright, 2005; Elliott, 1994; Elliott, 2003; Redlinger, Andersen, \& Morthorst, 2002). 
The degree to which proximity as an attribute influence individuals' attitudes towards green energy, especially wind turbines, have been found to be dependent on the geographic location, local characteristics of the area as well as the value of the land (Van der Horst, 2007; Warren, et al., 2005).

\subsection{Willingness to Pay or Accept Compensation for Green Power and Proximity}

The decision criteria for siting a renewable electricity facility, like any project associated with some external cost in our society, are partly based on identifying a socially optimal location that reduces the external costs to society. The welfare change associated with changes in the physical attribute levels of renewable energy such as location and proximity have been successfully valued (economically) with stated preference methods such as contingent valuation and choice experiment. Consumers' WTP and WTA compensation are forms of value measurement or welfare change that are frequently used by economists to elicit the value of a change in non-market attributes such as environmental quality. The choice between the use of either WTP or WTA compensation depends on who owns the property rights (Freeman, 2003).

In contrast to the numerous studies that have assessed how proximity as an attribute of a wind farm influences consumers' attitude, limited literature exist on the influence of proximity as an attribute of renewable energy on consumers' WTP for renewable electricity. Ladenburg and Dubgaard (2007), in a study on consumers' WTP a premium for proximity as an attribute of wind turbines, found that consumers are willing to pay a premium on top of their electricity bill to reduce visual disamenities that will be derived from a proposed offshore wind farm in Denmark. Danish respondents generally had a positive WTP to site wind turbines at greater distances off the coast. 
Using an unweighted main effects model, Ladenburg and Dubgaard (2007) found that Danish consumers were willing to pay 47, 98, and 125 euros/household/yr to move wind turbines from a base distance of 8 kilometer off the shore to distances of 12,18, and 50 kilometers, respectively. The positive WTP to reduce visual disamenities suggests that consumer prefer visual disamenities derived from wind turbines to be limited to greater distances relative to a baseline. On marginal basis, consumer's marginal WTP decreased with increasing distance from the coast. Such an inverse relationship in marginal WTP suggests that consumers perceive the environmental cost of wind farms in close proximity to the coast to be higher than wind farms at larger distances from the coast.

In a similar study, Krueger et al. (2011) elicited the value Delaware residents place on visual disamenities of offshore wind power projects by varying the distance from the proposed baseline distance of 0.9 miles from the shorelines to nine miles offshore. The results of this study showed that the external cost of wind turbines generally decreased as the distance of potential location of the turbine relative to the baseline proximity increased. On aggregate, the external cost associated with the wind farm project to all Delaware residents were $\$ 7.6$ million, $\$ 4.2$ million and $\$ 870,000$ annually for facilities located at varying distances of 3.6, 6, and 9 miles off the coastline, respectively.

\subsection{Willingness to Pay for Green Electricity and Location}

The value that consumers place on renewable electricity and its environmentally related attributes have been shown to vary based on where the proposed facility will be sited as well as the sampling location of respondents surveyed. The reasons for such variations have been attributed to a number of factors including perceptions of high environmental costs of a facility at a particular 
location relative to others. The aesthetic value of land in a particular locality may be so high that the local population prefers leaving it in its pristine nature rather than using it for any other beneficial project for the community. As a result, differences in consumers' WTP to develop a renewable energy between locations can be interpreted as the difference in environmental costs of development between locations (Ladenburg, 2009). From an environmental economist's perspective, the economic attractiveness of a proposed project such as a renewable energy may be determined by the monetary value that consumers place on the external costs associated with the project. Such value may also vary relative to its size and location (Ladenburg, 2009).

In a study of Chilean residents' preference for attributes of wind energy and perceived environmental costs, Aravena, Martinsson, \& Scarp (2006) found that an offshore location for a hypothetical wind energy development was significantly preferred over coastal, inland and mountain locations. Controlling for wind turbine impacts on birds and total area covered, consumers were willing to pay a higher premium (367-490 pesos per month) to site wind turbines further offshore relative to the coastal lines of Chile. Chileans were also willing to pay a positive premium to site wind turbines further offshore compared to the inland (340-356 pesos per month) and mountain locations (373-436 pesos per month). The positive WTP for siting wind farms at an offshore location relative to other locations presented in the choice set implies that consumers perceive the environmental costs of siting wind power at either on-land, coastal, or mountain locations to be higher than an offshore location (Aravena, Martinsson, \& Scarp, 2006).

A similar study sought to determine wind power generation demand in Sweden by varying environmental quality attributes (noise level, number of turbines, and height of turbines) and locational attributes (mountains, on-land, and offshore). This study found consumers were WTP a premium to site wind turbines offshore relative to on-land locations (Ek, 2006). Using a 
hypothetical change in cost of electricity as the monetary attribute and controlling for all other attributes besides location, Swedish consumers were willing to pay a premium (0.035) and (0.057) Swedish Kroner/kWh to site wind turbines offshore relative to on-land and mountain locations respectively.

Typical of non-market attributes valuation studies, the fact that consumers preferred offshore siting of wind farm relative to on-land locations and exhibited a positive WTP for offshore siting of wind turbines in both studies by Ek (2006) and Aravena (2005) can't be generalized. Other studies have shown that consumers' preference between offshore and on-land locations may be geographic location specific (McCartney, 2006). When presented with a hypothetical scenario of possible wind farm development on an inland location and a specific marine park (Jurien Bay Marine Park) location (beach and offshore), Australian consumers showed a high preference for the inland siting of wind turbines relative to coastal and offshore locations (McCartney, 2006).

Respondents including visitors to the park perceived the marine park to be pristine with a very high social value. In other words, Australia consumers perceived the environmental costs associated with developing a wind power facility at a marine park to be higher than an on-land location. The average temporary lump sum payment that consumers were willing to pay for siting wind turbines at the on-land relative to coastal and offshore locations over a twelve (12) month period were found to be AU\$ 36-43 and AU\$ 34-44 (Australian dollars), respectively.

Also, consumers' preferences for renewable energy attributes and WTP for renewable energy has been shown to differ with respect to the geographic location of a consumer's residence. A few studies have sought to test the hypothesis that preference for renewable energy and attributes of interest may be dependent on the geographic location of respondents' residences. A 
study of urban dwellers and rural dwellers preferences for renewable energy sources and size of the facility in Scotland showed that preferences for the two populations differ from each other yet both were generally influenced by similar attributes of renewable energy (Bergmann, Colombo, \& Hanley, 2008).

The parameter estimates of landscape change, impact on wildlife, air pollution, jobs, and cost as attributes of renewable energy were all found to be higher within rural dwellers compared to the urban dwellers (Bergmann, Colombo, \& Hanley, 2008). Given the choice between four energy sources (large offshore wind farm, large onshore wind farm, small onshore wind farm, and a biomass power plant) relative to an expansion of the baseline case (fossil fuel electricity project), rural dwellers were willing to pay a positive premium for all renewable energy sources with the biomass power plant being the highest ( 97.95 pounds/hsld/year). The number of jobs that will be created by the project was the most important attribute associated with the choice that rural dwellers made. On the other hand, urban dwellers were only willing to pay a premium for a large offshore wind farm (17.87 pounds/hsld/year) and the most important attributes that were associated with the choices they made included; no air pollution, landscape change and wildlife impact (Bergmann, Colombo, \& Hanley, 2008).

Specifying three sampling locations (inland, Bay area and Ocean area), consumers' WTP to reduce visual disamenities (a measure of external cost) from wind farm development off the shores of Delaware was shown to differ between ocean, bay and inland residents (Krueger, Parsons, \& Firestone, 2011). Using variations in proximity to a hypothetical wind farm location $(3.6,6$ and 9 miles) relative to the coastline ( 0.9 miles), ocean dwellers were willing to pay the highest premium $(80,69,35,27$ dollars/hsld/year) to reduce visual disamenities at the respective proximity levels of 3.6, 6 and 9 miles. Compared to the premium that inland area sampled population placed on 
proximity as an attribute of offshore wind energy $(19,9,1,0$ dollars/hsld/year), the bay area sampled population was willing to pay a higher premium $(34,11,6,2$ dollars/hsld/year) to move wind turbines from the baseline proximity to 3.6, 6 and 9 miles respectively (Krueger, Parsons, \& Firestone, 2011).

The differences in WTP for a reduced disamenity between the three location dependent sub-samples can be attributed to the differences in perceived environmental costs of wind power's visual disamenities by each group. Logically, ocean and bay dwellers with a permanent residence relatively close to the proposed project location perceived the external cost from wind turbines to be relatively higher at any proximity level compared to inland dwellers with a permanent residence farther away from the proposed project.

In summary, studies discussed in this section have shown that individuals' WTP for renewable energy is not uniform and usually depends on the perceived environmental costs associated with the facility. The perceived environmental costs associated with renewable energy is also dependent on the location of the facility (onshore, offshore, on-land, mountain etc.), individuals' residential location (urban, rural, ocean, bay and inland dwellers) and other attributes of interest. Logically, we can assert that individual's prior or current experience with some form of electricity generation facility will influence their choice of electricity generation source and WTP for attributes of interest given the options to choose.

Based on a review of the literature, only two studies (Ladenburg \& Dubgaard, 2007; Navrud \& Braten, 2007), have attempted to compare the consumers' WTP for green energy between subsample groups with permanent residence near an existing renewable electricity generation facility (prior experience with a renewable electricity facility) and a subsample group with no such 
facility near their current permanent residence (no prior experience with renewable energy facility).

Ladenburg and Dubgaard (2007) showed that Danish consumers' WTP for reduced visual disamenities from wind farms generally exhibited a preference for locating wind farms at greater distances offshore. Moreover, respondents who could see existing wind farm from offshore locations or had a summer house at a location with an offshore wind farm within view (5\% of 362 respondents) were willing to pay a much higher premium for a reduced disamenity. Compared to the WTP of the sampled population who don't have wind turbines within view from their current residence $(33,94$, and 107 euro/hsld/year), respondents who had a summer home along the coast or had wind turbines within view from their current residence were willing to pay between three to six times more in premium (280, 422 and 468 euro/hsld/year) for a reduction in disamenities that will be derived from moving wind turbines from the coastline to 12,18 and $50 \mathrm{~km}$. As a result, Ladenburg and Dubgaard (2007) asserted that respondents with an already existing view of wind farms from their residence or summer home had a strong preference for siting wind farm farther away.

The strong preference for a reduction in visual disamenities among residents with an existing offshore wind farm within view can also be attributed to a simple "not in my backyard" phenomenon (NIMBY). Residents' NIMBY tendencies perhaps stem from the assumption that future wind farms will be sited at the current location of the existing wind farm, which will compound the visual disamenities already experienced. Hence, prior experience with a visual disamenity influences consumers' preference negatively. Moreover, some consumers may see the ocean as a pristine location and prefer that the seascape be unaltered. Hence, their strong preference for reducing visual disamenities 
A similar but extensive study of consumer groups' preferences and WTP for renewable energy sources (wind, hydroelectric, and natural gas) in Norway, Navrud \& Braten (2007) found that the sub-sample from a predominantly urban area with no existing wind farm had a high preference for electricity generated from wind relative to the rural sub-sample with existing wind farms. The mean WTP for wind energy expansion among rural dwellers was relatively low (114.39 NOK/household/year) compared to urban dwellers (1168.33 NOK/household/year). Even though on average both sub-population groups were willing to accept a compensation for renewable energy generated from a hydroelectric source, the monetary value placed on hydroelectricity by rural dwellers was much less (-348 NOK/household/year) compared to the urban dwellers (-173 NOK/household/year).

Furthermore, the urban dwellers required a high compensation (-907 NOK/household/year) to replace coal-fired electricity with electricity generated from natural gas whereas rural dweller were willing to pay a positive premium (10 NOK/household/year) for electricity generated from natural gas. Navrud \& Braten (2007) also attributed the difference in preference and WTP between the two sub samples to a simple NIMBY phenomenon. Generally, respondents with an existing wind farm within view from their residence or have prior experience with an already existing facility perceive the environmental cost associated with visual disamenities of wind turbines to be higher relative to respondents with no existing wind farm currently within view from their residence. Ladenburg (2009) in a review of literature on wind energy facility locations asserted that such perceived high environmental costs by consumers predominantly leads to a NIMBY effects in society. 


\subsection{Literature Gaps}

A number of studies have investigated consumers' preferences and attitudes towards renewable electricity. The vast majority of these studies have focused on wind energy which is understandable because renewable energy from wind continues to be the fastest growing nonhydroelectric renewable energy source over the past decade in the United States (U.S. Energy Information Administration, 2015d). Currently, the literature that exists on consumers' preferences and attitudes towards other sources of renewable electricity besides wind is very scanty. The current push by states across the country towards cleaner energy sources (both renewable and cleaner non-renewable alternatives) has made it necessary to address consumer preferences and expand the existing body of literature for these alternative clean energy sources besides wind.

Furthermore, the attributes of renewable energy (environmental and non-environmental) and how they influence consumers' attitudes have been adequately documented over the years. Generally, consumers have exhibited a positive attitude and preference towards renewable energy (Farhar \& Houston, 1996). A significant number of non-environmental attributes of renewable energy that influence consumers' attitudes such as size of facility, type of renewable energy source, and consumers' proximity to a proposed or existing renewable electricity generation facility have seen varying and conflicting results. While most of the studies generally support the proximity hypothesis; others support the hypothesis that an inverse relationship exists between the proximity as an attribute and consumers' attitude (Braunholtz, 2003; Swofford \& Slattery, 2010; Warren, et al., 2005). 
In addition, the proximity of a consumer to a proposed facility and the consumer's current location relative to some form of electricity generation facility (current experience) have been shown to influence consumers' preferences and WTP for renewable electricity. Even though the proximity hypothesis has been shown to be valid in a vast number of studies, the assertion that individuals always prefer a power plant associated with some negative external cost to be located farther away from them cannot always be generalized. McCartney (2006), in a review of current literature that assessed the proximity hypothesis, asserted that consumers' preferences and WTP for siting a wind farm may be location specific and depends on the value of the land. Therefore, the perceived value of the location in question and the social context of the population being surveyed may also influence consumers' preference and WTP besides just proximity as an attribute (Van der Horst, 2007). Hence, when evaluating the impact of proximity as an attribute of green energy, the value of the land in question to the society and other socioeconomic characteristics need to be considered.

Largely missing in the literature on renewable energy is how an individual's geographic location relative to other existing forms of electricity generation facilities (coal, natural gas etc.) influence their preference and WTP for a proposed renewable electricity generation source. Based on the scanty literature available, an individual's current experience or non-experience with a particular electricity generation facility will influence his choice and perceived environmental cost of a proposed renewable source. Only two studies, (Ladenburg \& Dubgaard, 2007; Navrud \& Braten, 2007), were found that have considered variance in preferences and WTP for renewable energy between consumer groups at a location with an existing renewable energy facility and another with none. Both studies (Ladenburg \& Dubgaard, 2007; Navrud \& Braten, 2007), only 
focused on wind energy as an existing renewable electricity source and does not explicitly state what kind of facility, if any, exists in the other location considered.

Even though Navrud and Baten (2007) mentioned fossil fuel electricity generation expansion as the status quo source for the location with no current existing renewable energy facility, they do not explicitly state the specific geographic location of the facility or the percentage of sampled population who lived in close proximity to the facility. Also, (Ladenburg \& Dubgaard, 2007) only compared respondents with residences at locations where an existing wind farm is within view relative to respondents from other parts of Denmark with no such current view of a wind farm. Again, this study also failed to explicitly specify if a fossil fuel electricity generation facility exists at the location sampled or is within view of any of the sampled groups.

Based on the varying results on how proximity influences consumers' preferences, attitudes and WTP for renewable energy in the current body of literature, it's logical to assume that consumers' preferences, attitudes, and WTP for renewable energy will differ based on the type of electricity generation facility (renewable or fossil fuel) that already exists within the respondent's local area or within view from the respondent's current residence. Consequently, we can conclude that it's not rational to generalize the effects of renewable electricity generation sources' attributes on consumers' attitude, preferences and WTP for renewable electricity. There is no denial that proximity as an attribute of a renewable electricity facility influences consumers' attitudes, preferences, and WTP for renewable electricity; nevertheless the nature, strength and spatial scale of proximity variation is local context specific and also depends on the value of the land (Van der Horst, 2007). 
Hence, from a welfare economist perspective, a state like West Virginia with a large share of its economy heavily dependent on the coal industry faces a daunting task including public opposition as it seeks a balance and the right path to pursue an expansion in its renewable energy portfolio. Since the electricity customer base in West Virginia is ultimately going to be asked to pay an additional premium for an increase in renewable electricity share of the state's energy portfolio, the goals of any renewable energy policy will be successful and socially optimal if consumers' attitude, preference, and WTP for renewable energy are clearly understood by policy makers. Our study, being the first of its kind in West Virginia, seeks to address these important issues of consumers' WTP for renewable energy and preference for renewable energy. With results from this study, policy makers will be able to make important decisions such as; (1) siting locations for future renewable energy facilities that will be socially optimal, (2) the most preferred renewable source to pursue and (3) ways to mitigate NIMBY effects if it exists in West Virginia residents.

This study also seeks to generally add to the limited body of literature on how a consumer's current location relative to an existing electricity generation facility influences their preference and WTP by explicitly specifying two consumer groups. The specification of sub-population groups is based on individuals' location relative to an existing electricity generation source. It should be noted that the existence of a facility at a location to be surveyed does not imply that $100 \%$ of total electricity consumed by that group is supplied by the facility. We assume that electricity generation from any facility in the state enters a transmission grid and it will be difficult to identify the specific source of electricity generation being supplied to a consumer. 


\section{Chapter 3}

\section{Model Theory: Econometric Basis of Choice Experiment}

Economic theory assumes that individuals' are rational and they will strive to maximize their utility subjected to a budget constraint. Choices that an individual makes are based on these assumptions. In a choice experiment where non-market, environmental goods are valued, a researcher seeks to maximize the likelihood of observing a choice an individual makes by estimating weights on a set of attributes provided in the choice set (Freeman, 2003). Choice modeling is fundamentally based on the Lancaster Consumer Theory of Value and the Random Utility Theory (RUT) (Blamey, Gordon, \& Chapman, 1999; Lancaster, 1966; Louviere, 2001).

\subsection{Lancaster Consumer Theory}

In this section, the Lancaster Consumer Theory will be presented briefly. This theory has been extensively been discussed elsewhere in choice modeling literature (Alpizar, Carlsson, \& Martinsson, 2001; Lancaster, 1966). Lancaster's consumer theory asserts that consumers don't generate utility directly from a good but from the characteristics (or attributes) of the good. In general, a good may possess many characteristics as well as share characteristics with other goods. Even though the price of a good is a characteristic that is not directly consumed, it influences the utility of an individual (Alpizar, Carlsson, \& Martinsson, 2001). This theory assumes that, a bundle of goods may possess characteristics that will not be available if they were to be separated. In other words, the multiple characteristics of a good are in fixed proportions and a consumer's preference for a good is exercised if all these characteristics are available (Lancaster, 1966). 


\subsection{Random Utility Theory (RUT) and Individuals' Choice Model}

According to the RUT, an individual's utility is not directly unobservable. A fairly significant part of this utility can be elicited through the use of a carefully designed stated or revealed preference methods. Yet, there will always be a stochastic part of the individuals' utility that will remain unexplained (Louviere, 2001). Hence, according to this theory, the unobservable utility is assumed to embody two parts, an observable component and random unobservable component. Choice experiments as an economic valuation methodology are based on the application of both Lancaster Utility Theory and the Random Utility Theory (Hanley, Wright, \& Adamowicz, 1998). According to the RUT, the unobservable utility $\left(\mathrm{U}_{\mathrm{in}}\right)$ that an $n^{\text {th }}$ individual derived from choosing the $i^{\text {th }}$ option among alternatives in a choice $\operatorname{set} C_{n}$ is assumed to be a function of the attributes $\mathrm{X}_{i}$ and the characteristics of the $n^{\text {th }}$ individual $S_{n}$. The observable part of the latent utility derived by the $\mathrm{n}^{\text {th }}$ individual for the $i^{\text {th }}$ choice can be expressed as: $\mathrm{V}\left(\mathrm{X}_{\mathrm{in}}, \mathrm{S}_{\mathrm{in}}\right)$ and the unexplained random component of the derived latent utility expressed as $\varepsilon_{\text {in. }}$ The latent utility derived by the $n^{\text {th }}$ individual for the $\mathrm{i}^{\text {th }}$ choice can be expressed mathematically as:

$$
\mathrm{U}_{\mathrm{in}}=\mathrm{V}\left(\beta^{\prime} \mathrm{X}_{\mathrm{in}}, \mathrm{S}_{\mathrm{n}}\right)+\varepsilon_{\text {in }}
$$

Where $B$ represents the vector of parameter estimates associated with corresponding vector of attributes $X_{i n}$ of the $i^{\text {th }}$ choice an individual makes out of $J$ alternatives. $S_{n}$ is a vector of the observed $n^{\text {th }}$ individual's characteristics. The unexplained random component of the utility associated the $n^{\text {th }}$ individual's choice, which represents the unobserved component of $n^{\text {th }}$ individuals utility is represented by $\varepsilon_{\text {in }}$.

The functional form of the observable part $\left(\mathrm{V}_{\text {in }}\right)$ of the $n^{\text {th }}$ individual's latent utility $\left(\mathrm{U}_{i n}\right)$ derived from the $\mathrm{i}^{\text {th }}$ choice can be expressed as:

$$
\mathrm{V}_{\text {in }}=\beta_{0 i n}+\beta_{\text {lin }} f\left(X_{\text {lin }}\right)+\beta_{2 i n} f\left(X_{2 i n}\right)+\ldots . .+\beta_{\text {kin }} f\left(X_{\text {kin }}\right)
$$


Where the alternative specific constant (shifters of utility or on the average the source of unobserved utility) is represented by $B_{0 \text { in. }}$ Parameters of attributes up to the $K^{\text {th }}$ attribute for the $i^{t h}$ alternative is represented in the equation as $B_{1 \mathrm{in}}$. There are $K$ number of attributes $\left(\mathrm{X}_{1}, \mathrm{X}_{2}, \ldots, \mathrm{X}_{\mathrm{K}}\right)$ in the functional form of the observable utility in equation (3.2). Attributes of the $i^{\text {th }}$ choice can enter the utility function in different functional forms. The functional form of an attribute is represented as $f($.$) in the observable utility. These functional forms include but are not limited to linear, natural$ $\log$, quadratic functional forms or an interaction between two attributes. Equation (3.2) will be assumed to take a linear functional form in attributes throughout this study.

Differences in utility derived from alternatives across a choice set form the basis of model estimation in choice experiment (Holmes \& Adamowicz, 2003). The presence of a random component in the utility function implies that researchers have limited information about the choice an $n^{\text {th }}$ individual is making. As a result, the use of probability of choice method to explain utility derived by an $n^{\text {th }}$ individual has been the focus of CE studies over the years. This probability of choice formulation is based on the utility maximization theory and RUT (Bergmann, Hanley, \& Wright, 2006; Louviere, 2001). An $n^{\text {th }}$ individual will always choose the $i^{\text {th }}$ alternative among $J$ options in a choice set $C_{n}$ if:

$$
\mathrm{U}_{\text {in }}>\mathrm{U}_{\mathrm{jn}}, \quad \forall \mathrm{j}_{\mathrm{n}}, \mathrm{i} \neq \mathrm{j}
$$

The unobservable probability function of choice is given as:

$$
\mathrm{P}\left(i / \mathrm{C}_{\mathrm{n}}\right)=\mathrm{P}\left(\mathrm{U}_{\mathrm{in}}>\mathrm{U}_{\mathrm{jn}}\right), \quad \forall_{\mathrm{j}} \in \mathrm{C}_{\mathrm{n}}, \mathrm{i} \neq \mathrm{j}
$$

Where $\mathrm{P}\left(\mathrm{i} / C_{n}\right)$ is defined as the probability of choosing the $\mathrm{i}^{\text {th }}$ alternative given a choice set $\mathrm{C}_{\mathrm{n}}$. The observable probability of the choice function is given as:

$$
\mathrm{P}\left(i / \mathrm{C}_{\mathrm{n}}\right)=\mathrm{P}\left[\left(\mathrm{V}_{\mathrm{in}}+\varepsilon_{\mathrm{in}}\right)>\left(\mathrm{V}_{\mathrm{jn}}+\varepsilon_{\mathrm{jn}}\right)\right], \quad \forall_{\mathrm{j}} \in \mathrm{C}_{\mathrm{n}}, \mathrm{i} \neq \mathrm{j}
$$


For all $\mathrm{j}$ alternatives in choice set $C_{n}$, where $\mathrm{V}_{\mathrm{in}}$ is the indirect utility derived from the $\mathrm{i}^{\text {th }}$ choice by the $n^{\text {th }}$ individual among $J$ alternatives.

This means that the probability of an $n^{\text {th }}$ individual choosing the $i^{\text {th }}$ option from a choice set $C_{n}$ is equal to the probability that the indirect utility $\left[\mathrm{V}_{\text {in }}\right]$ plus the random component $\left[\boldsymbol{\varepsilon}_{\text {in }}\right]$ derived from choosing the $i^{\text {th }}$ alternative is greater than the indirect utility plus its random component derived from choosing $j^{\text {th }}$ alternative among the choice set (Louviere, 2001). Hence, researchers (with limited information) assume the $n^{\text {th }}$ individual follows the "random utility maximization rule". The rule states that the probability of the $n^{\text {th }}$ individual will choose the $i^{\text {th }}$ alternative is equal to the probability of the difference in the random components (unobserved) of utility associated with the $j^{\text {th }}$ and $i^{\text {th }}$ alternatives is less than or equal to the difference in observable utility associated with the $i^{\text {th }}$ and $j^{\text {th }}$ options among all options given in the choice set $C_{n}$ (Hensher, Rose, \& Greene, 2005). The random utility maximization rule can be expressed mathematically below as equation (3.6) by a simple rearrangement of equation (3.5):

$$
\mathrm{P}\left(i / \mathrm{C}_{\mathrm{n}}\right)=\mathrm{P}\left[\left(\varepsilon_{\mathrm{jn}}-\varepsilon_{\mathrm{in}}\right) \leq\left(\mathrm{V}_{\mathrm{in}}-\mathrm{V}_{\mathrm{jn}}\right)\right], \quad \forall_{\mathrm{j}} \in \mathrm{C}_{\mathrm{n}}, \mathrm{i} \neq \mathrm{j}
$$

The appropriate logit modeling platform adopted for the probability choice model will depend on the assumption given to the distribution of the random term. The extreme value type I distribution (EV1) has been widely used in discrete choice analysis over the years. The independently, identically distributed (IID) type I extreme value (EV1) is generally used as the starting point of most choice model derivation as a result of the simplistic nature of the models it presents (Louviere, 2001). The IID assumption customarily leads to the use of multinomial logit model (MNL) for the estimation of choice probability.

The MNL estimation of the probability of choosing the $i^{\text {th }}$ option can be expressed as a ratio of the exponent of observable utility derived from the $\mathrm{i}^{\text {th }}$ option (among $\mathrm{j}$ alternatives) to the exponential summation of all available alternative $(J=1, . . i, \ldots J)$. This ratio is mathematically 
presented in equation (3.7). The indirect utility $V_{\text {in }}$ is assumed to be a linear additive function in attributes.

$$
\operatorname{Pr}(i)=\frac{e^{V_{i}}}{\sum_{j=1}^{J} e^{V_{j}}}, \quad \mathrm{j}=1, . . \mathrm{i}, . . \mathrm{J} \quad \mathrm{i} \neq \mathrm{j}
$$

The use of MNL requires a restrictive assumption that choices are independent of irrelevant alternatives (IIA) (Hanley, Mourato, \& Wright, 2001). This assumption means that when one of two options is chosen, its relative probability is not affected by the addition or removal of other alternatives. The restrictive nature of the IIA does not appeal to researchers because it does not fully reflect consumers' behavior (Collins, Rosenberger, \& Fletcher, 2004). It also restricts all errors to have the same scale parameter and preferences to be identical for all respondents (Holmes \& Adamowicz, 2003).

In order to generalize the MNL model and relax the restriction imposed by the IIA assumption, a number of models have been developed that builds on the MNL model and improves choice behavior specifications. The two most widely used choice models that builds on the MNL are the nested logit (NL) model and the mixed logit (ML) model.

\subsubsection{Nested Logit Model}

The nested logit model (NLM) is recommended as the ideal model to be used to estimate the probability of choice if an opt-out option is included as a fixed alternative in any possible combination of attributes. Moreover, the restrictive assumption of IID and IIA by the MNL on the error term results in identical cross elasticity between all available alternatives (McFadden, 1981). Therefore, an addition of an opt-out alternative in the choice set will result in bias estimation whenever the strict assumptions on the error term are violated. The adoption of a nested logit model (NLM) allows for similar unobserved effects among alternatives in any nest of the partition. This overcomes the homoskedasticity assumption that may exist across groups. Nested logit model 
groups alternatives into sub groups (nested tree) which preserves the IIA assumption within groups and allows for variance across groups.

\subsubsection{Mixed Logit or Random Parameter Model}

The mixed logit model, a generalized conditional logit, on the other hand, has a number of advantages over the MNL that makes it the most preferred model discrete choice analysis. The most appealing property of the mixed logit is its ability to ease the restrictive IIA propriety of the MNL. The model also allows preference variation across the sampled population ( $\beta$ is not fixed). Mixed logit models allows correlation over alternatives in the stochastic portion of the individual's utility function (Hensher, Rose, \& Greene, 2005; Revelt \& Train, 1998). The specification of utility function using mixed logit follows the generalized utility maximization behavior of the standard logit model.

Following (Revelt \& Train, 1998; Train, 2009) and (Hensher, Rose, \& Greene, 2005), the utility derived by the $n^{\text {th }}$ individual from choosing the $i^{\text {th }}$ option among J alternatives, according to the mixed logit formulation, can be expressed as:

$$
\mathrm{U}_{\text {in }}=\beta^{\prime} X_{\text {in }}+\mu^{\prime} X_{\text {in }}+\varepsilon_{\text {in }}
$$

Where $X_{\text {in }}$ is a vector of observed attributes or explanatory variables and $\beta$ represents a vector of unobserved coefficients of $\mathrm{X}_{\text {in }}$ to be estimated. The unobserved coefficient varies across the population with a density function $f(\beta)$. Similar to the MNL model specification, the error term $\varepsilon_{\text {in }}$ of the mixed logit is assumed to be IID EV1 value which is independent of the vector of coefficients $(\beta)$ and the vector of explanatory variables $\left(X_{i n}\right)$. Even though the error component of the mixed logit model in equation (3.8) is specified as an IID EV1 across individuals, alternatives and choice situations, the mixed logit model allows for hetroskedasticity and correlation across alternatives through the introduction of an additional stochastic term $\mu$ into the classic random utility function from equation (3.1). This new stochastic term $\mu$ is introduced through the 
unobserved coefficients $(\beta)$. The conditional probability that the $n^{\text {th }}$ individual will choose $\mathrm{i}^{\text {th }}$ option among J alternatives in a choice situation is given as:

$$
L_{i n}\left(\beta_{n}\right)=\frac{e^{\beta^{\prime} X_{i n}}}{\sum_{j=1}^{J} e^{\beta^{\prime} X_{j n}}}, \quad \mathrm{j}=1, . . \mathrm{i}, . . \mathrm{J} \quad \mathrm{i} \neq \mathrm{j}
$$

Where $L_{n i}\left(\beta_{n}\right)$ is the logit choice probability evaluated at the unobserved parameters $\beta$. The unconditional mixed logit choice probability is derived by integrating the standard logit probability $\mathrm{L}_{\mathrm{ni}}\left(\beta_{\mathrm{n}}\right)$ over all possible values of the vector of coefficient $\beta_{\mathrm{n}}$ or a density of parameters. The unconditional mixed logit choice probability $\left(\mathrm{P}_{\mathrm{ni}}\right)$ can be expressed as:

$$
P_{\text {in }}=\int L_{\text {in }}(\beta) f(\beta) d \beta \quad \mathrm{j}=1, . . \mathrm{i}, . . \mathrm{J} \quad \mathrm{i} \neq \mathrm{j}
$$

Substitution $L_{\text {in }}$ in equation (3.10) with equation (3.9), the unconditional mixed logit choice probability becomes:

$$
P_{i n}=\int\left(\frac{e^{\beta^{\prime} X_{i n}}}{\sum_{j=1}^{J} e^{\beta^{\prime} X_{j n}}}\right) f(\beta) d \beta \quad \quad \mathrm{j}=1, . . \mathrm{i}, . . \mathrm{J} \quad \mathrm{i} \neq \mathrm{j}
$$

The mixed logit probability can simply be interpreted as a weighted average of the standard logit evaluated at all the possible values of $\beta$ and weighed using the density function $f(\beta)$. From equation (3.11), it can be deduced that the mixed logit simply becomes a standard logit as presented in equation (3.12) when the $\mathrm{f}(\beta)$ degenerate at fixed parameters $b$ such that $f(\beta)=1$ for $\beta$ $=b$ or $f(\beta)=0$ for $\beta \neq b$ (Revelt $\&$ Train, 1998).

$$
P_{i n}=\frac{e^{b^{\prime} X_{i n}}}{\sum_{j=1}^{J} e^{b^{\prime} X_{j n}}} \quad \mathrm{j}=1, . . \mathrm{i}, . . \mathrm{J} \quad \mathrm{i} \neq \mathrm{j}
$$


In specifying the mixed logit model, parameters of attributes $(\beta)$ associated with each option among J alternatives is specified as a random parameter with a mean and standard deviation. In order to illustrate this equation 3.8 is restated below.

$$
\mathrm{U}_{\text {in }}=\beta^{\prime} X_{\text {in }}+\mu^{\prime} X_{\text {in }}+\varepsilon_{\text {in }}
$$

The vector of coefficients $\left(\beta_{n}\right)$ estimated in equation (3.8) for the $n^{\text {th }}$ individual can generally be rewritten as:

$$
\beta_{n}=\beta+\mu_{n}
$$

Where $\beta$ is the parameter estimate (coefficient) for the population mean and $\mu_{\mathrm{n}}$ is the stochastic deviation of the individual's taste relative the mean preference of the population. The presence of unobserved preference heterogeneity within the sampled population is modeled into the mixed logit through the standard deviation parameter. This allows preferences for an attribute $\left(\beta_{n}\right)$ to differ within the population (Hensher, Rose, \& Greene, 2005; Train, 2009). For a particular random parameter estimate, the higher the standard deviation parameter, the more the preferences differ around the mean within the sampled population. Conversely the smaller the standard deviation parameter, the differences in preferences around the mean are lessened within the sampled population. A mixed logit model also allows the researcher to assume a number of behavioral distribution for each random coefficient through the density function. The most common distribution include, but are not limited to normal, lognormal, triangular, and uniform distribution (Hensher, Rose, \& Greene, 2005).

In order to compute choice probabilities over a mixed distribution, the mixed logit model approximates the choice probabilities through simulation that resembles independent random draws from a distribution on the unit interval (Hensher, Rose, \& Greene, 2005; Train, 2000). Instead of using a random draw sequence, which will require a large number of draws and 
invariably several hours in order to obtain stable parameter estimations and reduce simulation error, the Halton intelligent sequence draw is recommended (Hensher, Rose, \& Greene, 2005; Train, 2000). Bhat (2001) in a study that compared the random draw and Halton sequence found that simulation that utilized the Halton sequence was far superior to a random draw sequence.

\subsection{Log Likelihood Ratio Test: Comparing Utility Models for Two Populations (Grant and Monongalia County)}

As a result of the sampling methodology used in this study, two county level population models, and a pooled model of both counties were estimated to test for the statistical significance of the differences in choice for renewable and alternative electricity sources between the two populations sampled. The likelihood ratio test (LLR) was used for this purpose. The LLR test has a null hypothesis of equality in preference between all groups. If the LLR test fails to reject the null hypothesis then it means that the two counties sampled populations used in this study are from the same population and can be pooled together. Formally, the LLR test is stated:

$$
\begin{array}{ll}
L L R=-2\left[L L_{\text {pooled }}-\left(L L_{\text {Monongalia County }}+L L_{\text {Grant County }}\right)\right] \\
H_{0}: \beta_{\text {Monongalia County }}=\beta_{\text {Grant County }} & \text { (restricted model) } \\
H_{1}: \beta_{\text {Monongalia County }} \neq \beta_{\text {Grant County }} & \text { (unrestricted model) }
\end{array}
$$

The LLR test is asymptotically distributed as a chi square distribution $\left(\chi^{2}\right)$ with the degrees of freedom equal to the number of restriction imposed on the null hypothesis. In the equation presented above, the unrestricted model log likelihood is represented by the sum of the individual county population models' $\log$ likelihoods $\left(L L_{\text {Monongalia County }}+L L_{\text {Grant County }}\right)$, while the log likelihood of the restricted model is represented as the log likelihood of the pooled model $\left(L L_{\text {pooled }}\right)$. 


\subsection{Willingness to Pay Estimations}

The inclusion of a monetary attribute in the choice experiment allowed for the use of an implicit price function formulation to estimate the WTP for electricity generated from either wind or natural gas at varying proximity levels within the sampled population. When linearity in attributes exists, then the estimated WTP for a non-monetary attribute according to the implicit price formulation is the trade-off that a respondent would be willing to make between the non-monetary attribute and the monetary attribute (Bergmann, Hanley, \& Wright, 2006). This represents the respondent's WTP to gain or lose an attribute or some level of an attribute. The implicit price for a change in levels of proximity and source of renewable or alternative electricity as attributes was computed based on the mathematical formulation:

$$
\text { implicitprice }(z)=-\left(\frac{\beta \text { non_marketattribute }}{\beta \text { monetary_attribute }}\right)=-\left(\frac{\beta_{Z(\text { nonmarketattribute })}}{\mu}\right)
$$

The coefficient estimates represented as $\beta_{\mathrm{z}}$ is the marginal utility estimate of the non-market attribute level. The parameter $\mu$ is defined as the marginal utility of income. Since mixed logit formulation is based on the researcher specifying random parameters and its distributions, the WTP formulation will have to account for such variation in distribution and parameter specification. In this study, the monetary attribute was assumed to be fixed. Such an assumption for the cost parameter avoids the complexity and problems a researcher runs into when the ratio of two random parameters with different or identical distributions are estimated using the implication price formulation. Extensive literature exists on these computation problems on WTP and the logic behind assuming the cost parameter is fixed. Hensher, Shore, \& Train (2005), in a study on households' willingness to pay for attributes of water service extensively treated this computation problem and had numerous references for interested readers. 
In this study, WTP for electricity generated from wind relative to natural gas will be computed as using the implicit price formulation above. Other implicit price algorithms which builds on the basic formulation presented in equation (3.15) are available. These include the Krinsky-Robb (K\&R) method and the Delta method. The basic difference between these algorithms and the formulation presented in equation (3.15) is the ability of the later algorithms to perform repeated draws or simulations in estimating WTP.

In accounting for the random distribution of the $\beta$ parameters, (Hensher, Rose, $\&$ Greene, 2005) is followed in formulation of WTP using point estimates of mean and standard deviation for the random parameter. This general formulation of an $n^{\text {th }}$ individual's WTP for an attribute is presented in equation (3.16):

$$
W T P_{n}=-\left(\frac{\beta \text { nonmarketattribute }+(\text { SDattribute } * \text { RDraws })}{\beta \text { monetaryattribute }}\right)
$$

The estimation of each observation's WTP for an attribute $\left(\mathrm{WTP}_{\mathrm{n}}\right)$ accounts for the random parameter distribution through a multiplicative effect of a random draw from the specified distribution (Rdraws) and the point estimate of standard deviation (SDattribute) of the random parameter. The mean parameter estimate of the cost attribute ( $\beta$ monetaryattribute) is fixed and the mean parameter estimate of attribute of interest (Bnonmarketattribute) is random and can assume any distribution specified by the researcher in the mixed logit estimation. WTP for each observation in the study using equation (3.16) was estimated and the mean WTP was calculated for the population sample.

Since the choice experiment designed for this study did not have a status quo option, the baseline case for the proximity variable as an attribute of either wind or natural gas electricity generation source was the near proximity level (within 2 miles and within view). As a result, an 
individual's WTP for a new proximity level relative to the baseline is interpreted as the monetary value that the individual places on the resulting reduced disamenity when an electricity generation facility is relocated to a new proximity level relative to the baseline proximity. Based on this interpretation an individual's WTP to locate an electricity generation facility at a new proximity level $X_{i}$ relative to the baseline proximity $X_{0}$ can be expressed as equation (3.17) after rewriting equation (3.16):

$$
W T P_{n}=-\left(\frac{\left(\beta X_{i}+S D X_{i} * \text { RDraws }\right)-\left(\beta X_{o}\right)}{\beta m o n e t a r y a t t r i b u t e}\right)
$$

Where $\left(\mathrm{WTP}_{\mathrm{n}}\right)$ represents each observation's estimated WTP to locate an electricity generation source from the baseline parameter of near proximity to the $\mathrm{i}^{\text {th }}$ proximity level. The mean parameter estimate of the baseline proximity is given as $\beta X_{0}$. Since proximity as an attribute of an electricity generation facility was effect coded, $\left(\beta X_{0}\right)$ will take the value of $(-1)$ in equation (3.17). The mean parameter estimate of the $\mathrm{i}^{\text {th }}$ proximity level (either far or moderate proximity) relative to the baseline proximity is given as $\left(\beta X_{i}\right)$. For this study, the random parameter estimate for proximity levels are drawn from a normal distribution. The estimation of each observation's WTP for an attribute $\left(\mathrm{WTP}_{\mathrm{n}}\right)$ accounts for this through a multiplicative effect of a random draw from the normal distribution (Rdraws) and the point estimate of standard deviation (SDXi) of the random parameter. The mean parameter estimate of the additional fee attribute of the option chosen ( $\beta$ monetaryattribute) is treated as a fixed parameter in the WTP formulation.

The mean WTP that will be computed for the attributes of renewable and alternative electricity generation will be weighed against age and education levels to reflect that of the populations of the counties that will be surveyed. Both weighted and unweighted mean WTP for each attribute will be presented in the results section. The weighted WTP will also be aggregated to reflect the total households in each county. Two types of aggregation over each county's population will be done. 
First, aggregated annual WTP for the proximity attributes and energy source attributes will be computed based on the total number of households for each county. The second aggregated annual WTP for the proximity attributes and energy source attributes will be computed by adjusting for the percentage of non-responses in the total number of households in each county. In other words, the percentage of non-responses in each county's sampled population will be used to adjust the total number of households. 


\section{Chapter 4}

\section{Methods}

\subsection{Initial Questionnaire on Perception of Attributes of Interest}

In order to elicit preferences, attitudes and monetary values individuals place on renewable and alternative electricity, a survey was developed. Before the survey was developed, attributes that have to be included the choice experiment section to capture potential externalities or disamenities that are derived from an electricity generation source were identified by the research group in a series of meetings. Important attributes that were identified included the type of energy used to generate electricity, proximity of the respondent to the generation source and additional cost for clean electricity provision.

How these attributes would be incorporated in the survey and the levels they would take could not be decided without prior knowledge of how the target population understood these attributes. In order to develop an effective survey that is unambiguous in language to respondents, an initial set of questions were developed to ascertain potential respondents' knowledge, perception and opinions (both positive and negative) on renewable electricity and electricity generation in general. The environmental, economic and quality of life impacts of electricity generation (both positive and negative) from various source of energy were also included in this questionnaire to ascertain the impacts that are more important to potential respondents.

The most important aspect of the initial questionnaire specifically asked respondents how they perceived proximity to an object from their residence (in this case proximity to an existing power plant or wind farm). For example, the unique terrain of the Appalachian region compared to the flat plains of the Midwest United States presents contrasting concepts of how proximity to an object could be defined. Proximity as an attribute could be a contextual concept or a discrete unit 
measure. How an individual in the mountainous region of West Virginia defined what is farther or in close proximity to his or her residence could not be determined ex-ante.

Hence, the initial questionnaire concentrated on questions that asked potential respondents to explain how they would define what is too close in proximity or too far from their residential location. The questions also centered on renewable electricity and alternative electricity generation from various energy sources (wind, biomass, geothermal). Another important goal of this initial questionnaire was to determine the form of additional premium that resonates well with consumers and the appropriate levels they may take.

\subsection{Administering Initial Questionnaire (Intercept \& Semi-Structured Focus Group Interviews)}

Following a modified methodology used by Krueger \& Firestone (2011), a series of semistructured interviews and an intercept interview session were conducted using the initial questionnaire developed by the research group. Three sessions of interviews were conducted using the initial set of questions developed. The first series of interviews were conducted using an intercept format. These interviews were conducted during the annual "Celebration of America" event on July 4th 2012 at Hazel Ruby McQuain Amphitheatre, Morgantown West Virginia. This event usually attracts residents from Monongalia County and its neighboring counties in West Virginia. Individuals were randomly approached and the purpose of the questionnaire was introduced to them. An interview was conducted by reading each question carefully to individuals' who opted to participate. Respondents were promised anonymity and permission to use a digital audio recorder to record responses for later transcription was sought from each participant. Responses of individuals who objected to be audio taped were carefully recorded on a note pad. A total of twelve (12) individuals from three counties in West Virginia (Monongalia County, Marion County and Marshall County) were interviewed at this event. 
The second and third series of initial survey interviews were conducted as a semi-structured interview format. Two groups were recruited at two churches in Monongalia County, West Virginia. Leaders of these groups were approached and a formal request letter to interview the groups were sent. Requests for interviews were granted by both groups, and a thirty minute (30) meeting was scheduled in the first weekend of August 2012.

Each group participant was either the primary electricity bill payer or head of the household. Again, permission to digitally audio record the group meeting was sought from the group and granted. Each participant was given a questionnaire, and each question was answered one at a time as a group. The questions were read out loud and explained to the group. Participants were asked to record their responses to each question on the questionnaire. Concerns and opinions about each question presented on the questionnaire were discussed as a group. Important issues relating to electricity generation in West Virginia and the push towards renewable electricity were discussed. The number of individuals who participated in the two group interviews were fifteen (15) and nine (9) for the first and second groups respectively.

Audio recordings from the intercept and semi-structured group interviews were transcribed and summarized. Responses for each question were grouped under common themes. A similar technique was used to summarize responses recorded on a note pad. Based on results from these interviews, extensive literature reviews and numerous discussions with experts, a draft survey was designed.

\subsection{Pretest Monongalia County and Grant County}

In order to develop the final survey, it was important to pretest the draft survey. The main purpose of pretesting the survey was to ascertain the effectiveness of the survey design. During pretesting, important aspects of survey design including how the questions presented were understood by respondents, survey length, total number of questions included, questions structure, 
potential answers to questions not included and possible survey language bias were discussed (Dillman, 2000). Three pretest sessions were conducted within two counties in West Virginia (Monongalia and Grant Counties). An existing group that had regularly scheduled weekly meetings was recruited in both counties for the pretesting sessions.

The first pretest session was conducted at the United Universalist Church in Morgantown, West Virginia. Feedback from the first pretest session was considered by the research team and included in the construction of the second iteration of the draft survey. These include the number of choice profiles, attribute levels and number of choice questions to present in the choice experiment section. A second pretest session was conducted using the same group recruited at the United Universalist Church in Morgantown, West Virginia. Participants felt their concerns had been addressed and no major changes were made to the second iteration of the draft survey after the pretesting session.

The last pretesting session was conducted in Landes, Grant County. The local Ruritan Club in Landes was recruited for the pretesting of the second iteration of the draft survey. The pretesting session was conducted on a scheduled meeting day during the last week of March 2012. The group raised no major concerns about the survey. The layouts of some questions were changed based on the feedback from this group.

\subsection{Final Survey}

The final version of the survey included five basic sections. A copy of this survey can be found in appendix I of this study. The first section introduced the purpose of the survey and asked questions about the individual's electricity usage in order to determine the eligibility of the randomly selected individual that participated in this study. The second section of the survey explored an individual's knowledge, awareness and support for the current renewable and alternative portfolio standards (ARPS) in West Virginia. This section also touched on each individual's familiarity with current 
electricity generation sources, awareness of existing facilities and preferences for electricity generated from different energy sources in West Virginia.

The third section of the survey covered an individual's attitudes towards existing electricity generation facilities within the state (coal power plants and wind farms) or facilities with the potential to be built in the near future (natural gas-fired power plants). This section also explored an individual's attitudes, opinions and concerns on the environmental, economic and visual impacts of electricity generation facilities. The fourth section of the survey included a choice experiment that sought the monetary value that each individual places on the attributes of renewable and alternative electricity. The attributes included in this experiment include energy source, proximity and monetary attributes. The last section of the survey sought the socio-demographic characteristics of respondents. The design of the survey used in this study closely followed the “tailored design method" proposed by (Dillman, 2000).

\subsection{Experimental Design of Choice Experiment}

\subsubsection{Attributes and Levels of Attributes}

In order to design an effective choice experiment with an alternative pair of choices that resembles an actual choice an individual could face in the future, attributes of interest and the levels they will take have to be carefully chosen. Based on discussions at the semi-structured interview sessions and an extensive literature review on consumers' WTP for renewable electricity, three attributes were selected to be used in the choice experiment design. These attributes include: (1) energy source, (2) proximity of electricity generation facility relative to the current residence of a respondent and (3) an additional fee to be added to monthly electricity bill.

Borchers, et al. (2007) found that types of renewable energy sources like any other differentiated product on the market matters to consumers. The ability to differentiate between types of renewable sources is a result of the differences in attributes associated with each source. 
Two levels of energy sources were included in the choice experiment design. The levels were wind energy (renewable energy) and natural gas (alternative energy). Even though a number of energy sources qualified under the WV ARPS policy, only wind and natural gas were included in this study.

Wind energy and natural gas as electricity generation sources continue to be competitive in the United States. According to the West Virginia Department of Energy and the Public Service Commission (WVPSC), as natural gas continues to be competitive across the country, they expect more electricity generation facilities that utilize natural gas to be added to the state's electricity generation capacity compared to coal-fired sources in the near future (Public Service Commission of West Virginia, 2012). Also, the West Virginia ARPS allowed utility providers to use natural gas to fulfill up to $10 \%$ of the ARPS requirement.

As a result, the percentage of renewable (wind) and alternative (natural gas) electricity included in the choice experiment design was capped at $10 \%$ of the electricity that will be supplied to respondents ${ }^{3}$. Moreover, the WVPSC recently (February, 2015) issued a siting permit for a new natural gas-fired power plant to be built in Moundsville, WV. Based on these factors and the potential for natural gas to become a major part of the state's energy portfolio, the addition of natural gas as an attribute of generation source in this study was justified.

Wind as a renewable source of energy has been the fastest growing non-hydro renewable electricity generation source in West Virginia (U.S. Energy Information Administration, 2012b). According to the American Wind Energy Association (AWEA), West Virginia currently has 583MW installed capacity for wind energy (American Wind Energy Association, 2015). At least one of the major retail electricity companies (American Electric Power) operating in the state also indicated in

\footnotetext{
${ }^{3}$ Since the electricity that will be generation from wind and natural gas were capped at $10 \%$ in this study, it was assumed that the variability of wind as an energy source will not be a constraint to utility provider in the continual provision of $10 \%$ of renewable electricity (wind) per month to consumers. If a higher share of renewable electricity generated from wind is required then the complementarity relationship that exist between electricity generated from natural gas and wind will have to be addressed.
} 
their 2014 RPS compliance filings that it intended to pursue wind power purchasing agreements within the PJM region as one of the sources of energy in order to fulfill their obligations under the adopted RPS (Public Service Commission of West Virginia, 2014).

Other energy sources that qualified under the WV ARPS were explored. The potential of energy derived from biomass to be a significant part of the state's energy portfolio, at least in the short term, was seen as limited. There had been plans in the past to build a biomass-coal co-generation power plant in Mingo County, WV. American Clean Energy acquired a siting permit for a biomassfired power plant in Mingo County but the project was suspended. Biomass as an energy source was included in the initial questionnaire for the focus group discussion. Based on the focus group discussions and the limited potential of biomass as a major energy source in the state's energy portfolio, a decision was made not to include biomass as an attribute level in the choice experiment design.

Based on the discussions at the semi-structured interview sessions, as well as a series of discussions between the research group members, three levels of proximity (near, moderate and far) were used in the choice experiment design. Proximity was not presented as a measure of just distance but also as a measure of perceived impacts of the facility on visual effects, pollution, property value and noise. The corresponding impacts associated with the three levels of proximity used in this study followed details provided on externalities of electricity generation by Rowe et al. (1995). Rowe et al. (1995) used simulation models to estimate externalities associated with electricity generated from different sources of energy. A separate table of proximity levels along with associated impacts was presented as an appendix at the end of the survey. Respondents were encouraged to refer to the appendix before answering the choice experiment questions. Table 4.1 replicates the appendix section from the survey. 
In order to quantify the monetary value that respondents place on electricity generated from renewable and alternative energy sources, an additional fee on the monthly electricity bill was included as the monetary attribute of the choice experiment design. This additional fee was presented as the premium that consumers will have to pay for $10 \%$ of electricity supplied to them to be generated from either wind or natural gas. The use of an additional fee on consumers' monthly electricity bills as the monetary attribute resonated very well with respondents during the semi-structured interview sessions. Other non-economic valuation studies on renewable electricity attributes have successfully utilized additional fee on monthly electricity bill as cost of provision of clean energy (Krueger, Parsons, \& Firestone, 2011; Meyerhoff, Ohl, \& Hartje, 2010; Popkin, Duke, Borchers, \& Ilvento, 2013)

After an extensive discussion with focus group participants and pretest sessions, six levels of additional fees as an attribute of renewable electricity were used in design of the choice experiment. The levels ranged from $\$ 1$ per month up to $\$ 15$ per month. The average monthly electricity bill per residential customer in West Virginia was estimated to be \$106.15 in 2012 (U.S. Energy Information Administration, 2014). Hence, the range of monthly fees used in this study was approximately between $1 \%$ and $14 \%$ of the average monthly electricity bill per residential customer using the 2012 estimate. During the pretesting phase of the survey, the additional fee levels also resonated well with respondents. A summary of attributes and their levels in the choice experiment design are presented in Table 4.2 . 
Table 4.1. Appendix of survey: Impacts of wind and natural gas power based on location.

\begin{tabular}{|c|c|c|}
\hline \multirow[b]{2}{*}{ Location } & \multicolumn{2}{|c|}{ IMPACTS } \\
\hline & $\begin{array}{l}\text { Wind Turbine Facility (Wind Power) } \\
150 \text { Megawatts }\end{array}$ & Natural Gas Power Plant (210 Megawatts) \\
\hline $\begin{array}{l}\text { Near Your } \\
\text { Residence }\end{array}$ & $\begin{array}{l}\text { Distance: within } 2 \text { miles } \\
\text { Visual: High visibility of turbines } \\
\text { Noise: Disturbance can occur } \\
\text { Property Value: Moderate decline in } \\
\text { value (1\%) within } 0.5 \text { miles } \\
\text { Pollution (Environment and health): } \\
\text { None }\end{array}$ & $\begin{array}{l}\text { Distance: within } 2 \text { miles } \\
\text { Visual: High visibility of Stack and Smoke } \\
\text { Noise: None } \\
\text { Property Value: Moderate decline } \\
\text { (1-2\%) within a mile } \\
\text { Pollution (Environment and health): High } \\
\text { health effects: } 5 \text { times greater than } \\
\text { residential locations that are far away }\end{array}$ \\
\hline $\begin{array}{l}\text { Moderate } \\
\text { Distance } \\
\text { From Your } \\
\text { Residence }\end{array}$ & $\begin{array}{l}\text { Distance: Between } 2 \text { to } 19 \text { miles } \\
\text { Visual: Medium visibility of turbines } \\
\text { Noise: None } \\
\text { Property Value: None } \\
\text { Pollution (Environment and health): } \\
\text { None }\end{array}$ & $\begin{array}{l}\text { Distance: Between } 2 \text { to } 19 \text { miles } \\
\text { Visual: Medium visibility of stack and smoke } \\
\text { Noise: None } \\
\text { Property Value: None } \\
\text { Pollution (Environment and health): High } \\
\text { health effects: } 5 \text { times greater than } \\
\text { residential locations that are far away }\end{array}$ \\
\hline $\begin{array}{c}\text { Far Away } \\
\text { From Your } \\
\text { Residence }\end{array}$ & $\begin{array}{l}\text { Distance: At least } 19 \text { miles or greater. } \\
\text { Visual: Turbines are too far away to see } \\
\text { Noise: None } \\
\text { Property Value: None } \\
\text { Pollution (Environment and health): } \\
\text { None }\end{array}$ & $\begin{array}{l}\text { Distance: At least } 19 \text { miles or greater. } \\
\text { Visual: Minimal visibility of smoke if at all } \\
\text { visible. Stack may be too far away to see } \\
\text { Noise: None } \\
\text { Property Value: None } \\
\text { Pollution (Environment and health): Low } \\
\text { health effects compared to locations that are } \\
\text { at near and moderate distances }\end{array}$ \\
\hline
\end{tabular}


Table 4.2. List of attribute and levels used in choice experiment design.

\begin{tabular}{|c|c|}
\hline Attributes & Levels \\
\hline Energy Source & Wind, Natural Gas \\
\hline Proximity & Near, Moderate, Far \\
\hline Additional Fees & $\$ 1, \$ 2, \$ 5, \$ 10, \$ 12, \$ 15$ \\
\hline
\end{tabular}

\subsubsection{Design of Choice Sets}

During the experimental design phase of this study (March, 2013), the West Virginia ARPS policy had already been enacted and was on pace to be enforced in 2015. As a result, a forced choice experiment design with no option for a status quo or opt out was presented to respondents. Moreover, the choice situations in this study were labeled. A labeled choice experiment was used in this study because externalities derived from electricity generated from different energy sources (wind energy and natural gas-fired) at a particular location widely vary from each other as proximity increases.

Before the choice experiment section was presented in the survey booklet, an introduction to the hypothetical choice situations that respondents were about to answer was given. Within the preamble to the choice questions, respondents were informed of the impending ARPS policy in West Virginia. Attributes associated with each option were introduced succinctly and respondents were encouraged to think of each choice question independently and choose an option. Each respondent was presented with three choice questions. Each choice question had two labeled alternatives. Alternatives presented were always a choice between electricity generated from wind energy and natural gas. 
In designing choice combinations or questions, a full factorial choice design was considered, but the total number of choice sets that resulted from this design was enormous. With two levels of energy sources, three levels of proximity and six levels of fees, the total number of choice combinations resulting from a full factorial design was 1,296 choice set $(2 * 3 * 6) * 2$. The enormous total number of choice combinations from the full factorial design were unrealistic given the survey length and the time it would take to answer all the questions.

Following a SAS source code authored by (Kuhfeld, 2005), an orthogonal main effect, efficient and optimal design was used to develop the choice combinations for this survey. A total of 36 choice combinations with two labeled alternatives in each combination were developed. Even though the total number of choice sets resulting from the orthogonal main effect design was much smaller than the full factorial design, the ability of each respondent to answer all 36 questions in a survey was still regarded as unrealistic. In view of that, the 36 choice combinations were randomized and blocked into three questions per block. This resulted in a total of twelve (12) blocks of choice combinations. Each respondent was randomly assigned to a block. Figure 4.1 depicts an example of a typical choice set presented in the survey.

Even though the monetary value placed on proximity as an attribute was an important aspect of this choice experiment, no attempt was made to eliminate choice combinations in which the fee attribute for the farthest proximity was not higher than the fee attribute of the near or moderate proximity. The research team reached this consensus because the choice experiment designed for this study was labeled and not generic. Hence, the perceived externalities associated with a natural gas-fired power plant and wind farm cannot be directly compared using proximity as an attribute only. For an example, the perceived externality from a natural gas-fired power plant at a moderate proximity from a respondent's residence cannot be assumed to be higher than a wind farm located far from the respondent's residence. 
16) Currently, $100 \%$ of your electricity comes from coal energy. Assume you have the opportunity to choose a renewable or alternative electricity source and where it is generated (location of the facility). This energy source will fulfill $10 \%$ of the electricity supplied to your home. Which of the following options will you choose?

\begin{tabular}{|c|c|c|}
\hline Energy Source & Wind & Natural Gas \\
\hline $\begin{array}{l}\text { Location of power } \\
\text { plant relative to your } \\
\text { residence } \\
\text { (Refer to the } \\
\text { Appendix for } \\
\text { comparisons of near, } \\
\text { moderate and far } \\
\text { away) }\end{array}$ & $\begin{array}{l}\quad \text { Near } \\
\text { Distance: Within } 2 \text { miles } \\
\text { Visual: High visibility of turbines } \\
\text { Noise: Disturbance can occur } \\
\text { Property Value: Moderate } \\
\text { decline in value (1\%) within } 0.5 \\
\text { miles } \\
\text { Pollution (Environment and } \\
\text { health): None }\end{array}$ & $\begin{array}{l}\quad \text { Far Away } \\
\quad \text { Distance: At least } 19 \text { miles or } \\
\text { greater. } \\
\text { Visual: Minimal visibility of smoke if } \\
\text { at all visible. Stack may be too far } \\
\text { away to see } \\
\text { Noise: None } \\
\text { Property Value: None } \\
\text { Pollution (Environment and } \\
\text { health): Low health effects } \\
\text { compared to locations that are at } \\
\text { near and moderate distances }\end{array}$ \\
\hline $\begin{array}{c}\text { Cost (An increase in } \\
\text { your current monthly } \\
\text { electricity bill) }\end{array}$ & $\$ 5$ & $\$ 10$ \\
\hline $\begin{array}{l}\text { I will choose... } \\
\text { (Please check only one) }\end{array}$ & $\square$ Wind & $\square$ Natural Gas \\
\hline
\end{tabular}

Figure 4.1. Sample choice set presented to respondents.

Following an extension of the methodology used by Ready, Champ, \& Lawton (2010) to mitigate hypothetical bias, a scale of certainty of choice ( $1=$ Very uncertain to $10=$ Very certain) was presented immediately following each choice question. Since this study used a forced choice experiment, recalibration of uncertain choices made by respondents as an opt-out for status quo option in order to account for hypothetical bias was not possible. One option that was available to explore possible hypothetical bias was to reject all choices made with uncertainty levels less than seven (7=fairly certain) in all model estimations. 


\subsection{Sampling}

The difference in preferences and WTP that may exist between sub-population groups based on their prior experience with different types of electricity generation facilities that currently exists in their locale was an important aspect of our study. It was assumed that current facilities existing within the locale of an individual's residence will influence the type of renewable or alternative energy source and the attribute levels preferred. Thus, an individual's experience may dictate perceived environmental cost or benefits of a newly proposed renewable or alternative electricity generation facility. Although the type of energy source for an existing electricity generation facility was not explicitly mentioned in the choice experiment section or presented as an attribute, it was the basis of our sampling for this study. This sampling technique provided us the ability to compare the preferences of two sample groups within West Virginia and test whether they differ.

A handful of studies on economic valuation of non-market attributes of renewable and alternative electricity have sought to test the hypothesis that significant differences in preference for renewable energy attribute exist between population groups with versus without experiencing the impacts of existing electricity generation facilities (Krueger, Parsons, \& Firestone, 2011; Ladenburg \& Dubgaard, 2007; Navrud \& Braten, 2007). Even though the idea of such stratified sampling technique used in this study was novel, at least to some degree, it closely followed seminal studies on consumers' preferences and WTP for renewable electricity done by Navrud \& Braten (2007) and Ladenburg \& Dubgaard (2007). Two criteria were used to select eligible counties in West Virginia in which we will randomly sample a representative population to survey. The criteria were:

(1) A county with existing coal-fired electricity generation facilities.

(2) A county with both a wind farm and a coal-fired electricity generation facility. 
Monongalia County and Grant County were selected as two counties that meet our sampling criteria. Monongalia County is located in north-central West Virginia on the border of Pennsylvania. The county currently has four existing coal-fired power plants (Morgantown Energy Facility, two located at Fort Martin Power Station, and Longview Power plant) in operation. The current population estimate puts Monongalia County's population at 102,274 (U.S. Census Bureau, 2013). Monongalia County satisfied our first criterion of a county with only coal-fired power plants. The U.S. Census Bureau classifies Monongalia County as part of a metropolitan statistical area (MSA), which include neighboring Marion County.

Grant County, on the other hand, is a more rural county located in the eastern part of West Virginia. The county was selected based on the second criterion of sampling used in this survey. Currently, two existing coal-fired power plants (Mount Storm power plant and North Branch power plant) and a wind farm (NEDPower/Shell Project) are operational within the county. The U.S. Census Bureau (2013) estimates the current population of Grant County to be 11,759. A map of West Virginia identifying Monongalia County, Grant County and the all existing electricity generation facilities within the counties can be found in appendix II in the appendices section of this study.

Since all consumers of electricity will be directly impacted (at least financially) by a shift towards increasing the share of electricity from renewable and alternative energy sources in West Virginia, the population of interest in each county included all primary electric utility customers. It was assumed that the primary customer in each household was either the head of the household or a primary decision maker of the household. Valid survey response eligibility was determined by explicitly asking the randomly selected participants whether they are the primary bill payer or decision maker of the household. In view of the relatively large population that will be directly 
impacted by the current ARPS policy, this study adopted a representative random sampling approach in each county.

Even though the target population for this study was all electric utility customers within each county, I was not able to gain access to utility customers' data as a result of privacy concerns expressed by both utility providers from the two counties of interest. A closely related proxy of utility customers' data was a homeowners and renters mailing list. Since it cannot be assumed that all homeowners or renters are primary electricity bill payers or customers of the retail electricity supplier, a question was included in the introduction section of the survey to separate out the sampled population who were not the primary electricity bill payer or customer. Respondents who were not the primary customer of the electric company or the primary electric bill payer were considered out of scope and discarded from our analysis.

Lists of current homeowners and renters for each county were obtained from USADATA INC, NY, a data-marketing firm. Two mailing lists (including name) of 6,000 randomly sampled homeowners and renters from the two counties $(3,000$ for each county) were obtained during the first week of October 2013. According to USADATA INC, the mailing list of homeowners and renters are updated every quarter. Sampling was assured to be random based on a software algorithm used by the company. After excluding samples with unknown housing status (either renter or homeowner), 1,500 homeowners and renters from each county were randomly selected from these mailing lists obtained from USADATA INC to participate in the survey. Based on the population size of Monongalia County and Grant County, a randomly selected sample size of 1,500 participants for each county was considered to an be appropriate representation of the county's population. 


\subsection{Survey Administration}

A modified version of the tailored design method (Dillman, 2000) was used to administer the survey in this study. The survey was conducted between November 1st, 2013 and March 15th, 2014. This time frame extended beyond the recommended 8 weeks outlined in the tailored design method. The extension of the time frame was necessary because selected participants did not receive the first invitation to participate in the survey until the second week in November which was very close to the holiday season. The tailored design method recommend surveys to be sent after the holiday season and not right before the season. Even though our timing of administering the survey was not ideal, time and logistic constraints necessitated the survey to be administered as soon as possible.

An invitation to participate in either a mail or an internet survey was sent to the randomly selected sample populations in both Monongalia and Grant Counties. For the Grant county surveyed population, the invitation to participate in the survey included a copy of the mail survey and an option to participate online. The decision to include a mail survey in the initial invitation stemmed from the assumption that high speed internet provision may be limited in rural Grant County compared Monongalia County. Participants were given the option to either ignore the mail survey and participate online using a unique access code or complete and return the mailed survey. High speed internet was accessible to most residents in Monongalia County, as a result, participants were sent only an invitation to either participate online using a unique access code or request a mail survey by checking a box on the invitation and mailing it back to us.

Survey packets were mailed in a standard envelope with West Virginia University logo and address preprinted on it. Included in the survey packet were a personalized invitation letter, a first class prepaid return envelope and a paper version of the survey for the Grant county sample population. A personalized letter introduced the purpose of the survey, how the respondent was 
selected to participate, and the importance of his or her contribution in shaping future policy on renewable and alternative energy in West Virginia. Between the first invitation request and the last reminder letter, a total of six contacts were made with the sampled population of Monongalia County. These contacts include an initial invitation to participate, requested survey packet, two post card reminders, a replacement survey to non-responders, and a final reminder to nonrespondents. Since the first contact survey packet for the population sample in Grant County included both an invitation to participate and a paper version of the survey, only five contacts were made with this sample population.

Twelve versions of the survey were created to reflect the twelve blocks of the choice experiment design. Each respondent who requested for a paper survey in Monongalia County was randomly assigned to a single version of the survey. Each respondent in the Grant County sampled population was also randomly assigned to a particular survey version.

The Online survey was administered using an online survey software provided by Qualtrics LLC. This online survey software was used for this study because it had the capability of blocking the choice experiment questions and randomly assigning a block to each participant who completed the survey online. One advantage of the online survey version was that Qualtric software did not only ensure random assignment of each respondent to a particular block but also made sure that each block was evenly presented to the population who completed the survey online. A copy of the online version of the survey for Monongalia County and Grant County can respectively be accessed using the following URL: http://wvu.qualtrics.com/ife/form/SV efhaDDKkdW5u3Qh and http://wvu.qualtrics.com/SE/?SID=SV dj98WHDjFtsFKV7. A unique identifier code will be require to access the full survey. 


\section{Chapter 5}

\section{Descriptive Survey Data Analysis}

\subsection{Survey Response Rate}

A total of 3,000 invitations to participate in this study were mailed to randomly selected households in both Monongalia and Grant County (1,500 in each county). The effective response rate for the survey in Monongalia County was 27\%. This included 155 useable surveys completed online and 225 usable paper surveys returned by mail (Table 5.1). A total of 71 respondents (both online and paper survey) were either ineligible to participate or were considered out of scope. This study considered respondents who were unable to be reached (wrong addresses), deceased, disabled or have some form of severe illness as out of scope respondents. Respondents who indicated that they were not the primary bill payers or primary household decision makers were considered to be ineligible to participate in this survey.

Ineligible or out of scope responses were excluded from the final data analysis of this study. As a result, the effective response rate is based on survey or invitation mailed to 1,429 eligible participants. As anticipated, the difference in response rate between online participation (11\% response rate) and paper survey participation (16\% response rate) in Monongalia County was not that high. We attributed this to the high rate proliferation of broad band internet in the county compared to other rural counties in West Virginia.

On the other hand, after accounting for out of scope (32) and ineligible (48) respondents, the effective survey response rate in Grant County was 35\%. In total, 432 eligible returned responses were paper surveys (31\% response rate) while only 66 eligible responses (4\% response rate) were 
retrieved from the online survey platform (Table 5.1). The limited online survey participation in Grant County was attributed to limited access to broad band internet in the county.

Table 5.1. Summary of sample size and survey response rate.

\begin{tabular}{|l|c|c|}
\hline & $\begin{array}{c}\text { MONONGALIA } \\
\text { COUNTY } \\
\text { (n) }\end{array}$ & $\begin{array}{c}\text { GRANT COUNTY } \\
\text { (n) }\end{array}$ \\
\hline Original Sample Size & 1500 & 1500 \\
\hline Eligible Online Survey Responses & 155 & 66 \\
\hline Eligible Paper Survey Responses & 225 & 435 \\
\hline $\begin{array}{l}\text { Ineligible and Out of Scope } \\
\text { (Both Online and Paper Surveys) }\end{array}$ & 71 & 80 \\
\hline $\begin{array}{l}\text { Total Eligible Returned Responses } \\
\text { (Both Online and Paper Surveys) }\end{array}$ & 380 & 501 \\
\hline $\begin{array}{l}\text { Sample Size (Accounting for Out of Scope \& } \\
\text { Ineligible Respondents) }\end{array}$ & 1429 & 1420 \\
\hline Response Rate (Online Survey) & $11.0 \%$ & $4.6 \%$ \\
\hline Response Rate (Paper Survey) & $16.0 \%$ & $30.6 \%$ \\
\hline $\begin{array}{l}\text { Total Response Rate (Online \& Paper } \\
\text { Surveys) }\end{array}$ & $27.0 \%$ & $35.3 \%$ \\
\hline
\end{tabular}

According to Dillman (2000), the total number of completed surveys required for the opinions of the sampled population in Monongalia County and Grant County to be representative of the respective counties at 95\% confidence interval were 380 and 354 households respectively. This sampling methodology assumes a $\pm 5 \%$ error of sampling and each of the two alternatives presented in a choice situation (wind vs. natural gas option) were given an equal chance of being chosen. Based on the total number of eligible responses returned for this study from both counties (Monongalia County: 380 vs. Grant County 501) ${ }^{4}$, it can be asserted that the opinions of the sampled

\footnotetext{
${ }^{4}$ Opinions of respondents presented in the descriptive statistic section (chapter 5) used the total valid responses returned. As a result, opinion expressed in the descriptive statistic section can be extrapolated to represent the total households of each county respectively at $95 \%$ percent confidence interval.
} 
population in both counties can be extrapolated to represent the opinions of the total households of the respective counties at $95 \%$ confidence interval.

It should be noted that, as a result of incomplete sections of some returned surveys, the total number of respondents included in the final utility models of choices made by respondents were less than the total valid returned surveys (Mon County: 312 vs. Grant County 389). At $\pm 5 \%$ sampling error, the utility model developed for the sampled population in Monongalia County cannot be extrapolated to represent the utility of the total county households (expected number of respondents: 380 vs. actual number of respondents: 312$)$. On the other the hand, the Grant County utility model can be extrapolated to represent that of the total county households at 95\% confidence interval.

If the sampling error is increased to $\pm 10 \%$, then the opinions expressed by the final sampled population used in the choice models of counties can be extrapolated to represent the total households of each respective county at 95\% confidence interval. Table 5.2 depicts the total households expected to be sampled in each county in order for the model that were developed to be representative model of the respective county households.

Table 5.2. Expected sample size based on probability sampling methodology (Dillman, 2000).

\begin{tabular}{|c|c|c|c|c|c|}
\hline \multicolumn{3}{|c}{} & \multicolumn{3}{c}{$\begin{array}{c}\text { Expected Sample Size: } \\
\text { 95\% Confidence interval. } \\
\text { (Dillman 2000) }\end{array}$} \\
\hline \hline & $\begin{array}{c}\text { Total } \\
\text { County } \\
\text { Households }\end{array}$ & $\begin{array}{c}\text { Total Eligible } \\
\text { Returned } \\
\text { Responses }\end{array}$ & $\begin{array}{c}\text { Total Responses } \\
\text { Used in Choice } \\
\text { Models }\end{array}$ & $\begin{array}{c}\text { Sampling } \\
\text { Error: } \pm \\
\mathbf{1 0 \%}\end{array}$ & $\begin{array}{c}\text { Sampling } \\
\text { Error: } \pm \mathbf{5 \%}\end{array}$ \\
\hline $\begin{array}{c}\text { Monongalia } \\
\text { County }\end{array}$ & 36,449 & 380 & 312 & 68 & 380 \\
\hline $\begin{array}{c}\text { Grant } \\
\text { County }\end{array}$ & 4,449 & 501 & 389 & 67 & 354 \\
\hline
\end{tabular}




\subsubsection{Summary Characteristics of Respondents Population}

Table 5.3 presents summary statistics of important demographic characteristics of the sampled population and overall county population from both counties. The largest differences between the two county populations are education level and median household income. These observations were not surprising given that Monongalia County is home to two major hospitals in West Virginia and a state university. These three establishments require a highly skilled and educated labor force. As a result, the likelihood of sampling highly educated respondents in Monongalia County is very high compared to most counties in West Virginia. Also, all things being equal, education level is positively correlate to income level. Therefore, the slightly higher median income level observed in the Monongalia County population compared to the population in Grant County was not surprising.

Table 5.3. Summary of sample characteristics and population characteristics.

\begin{tabular}{|l|c|l||c|c|}
\hline & $\begin{array}{l}\text { Monongalia } \\
\text { County } \\
\text { Surveyed } \\
\text { Respondents }\end{array}$ & $\begin{array}{l}\text { Population } \\
\text { Demographics } \\
\text { Monongalia } \\
\text { County }\end{array}$ & $\begin{array}{l}\text { Grant County } \\
\text { Surveyed } \\
\text { Respondents }\end{array}$ & $\begin{array}{l}\text { Population } \\
\text { Demographics } \\
\text { Grant County }\end{array}$ \\
\hline Total County Households & 1500 & $36,449^{\mathrm{b}}$ & 1500 & $4,449 \mathrm{~b}$ \\
\hline $\begin{array}{l}\text { Education (Percentage } \\
\text { share with at least 4 year } \\
\text { college Education) }\end{array}$ & $\begin{array}{c}56 \% \\
(\mathrm{n}=371)\end{array}$ & $37.3 \%^{\mathrm{a}}$ & $\begin{array}{l}26 \% \\
(\mathrm{n}=485)\end{array}$ & $10.9 \%^{\mathrm{a}}$ \\
\hline Median Age (years) & 67 & $29.1^{\mathrm{b}}$ & 64 & $44^{\mathrm{b}}$ \\
\hline $\begin{array}{l}\text { Median Household } \\
\text { Income (per year) }\end{array}$ & $\begin{array}{l}\$ 50,000- \\
\$ 74,999\end{array}$ & $\$ 41,326^{\mathrm{c}}$ & $\begin{array}{l}\$ 35000- \\
\$ 49,999\end{array}$ & $\$ 40,250^{\mathrm{c}}$ \\
\hline Percentage of Females & $\begin{array}{l}52^{\mathrm{b}} \% \\
(\mathrm{n}=373)\end{array}$ & $48.5 \%^{\mathrm{d}}$ & $\begin{array}{c}47 \% \\
(\mathrm{n}=496)\end{array}$ & $50.4 \%^{\mathrm{d}}$ \\
\hline
\end{tabular}

a Reflects observations age 25 and above

${ }^{b}$ U.S. Census Bureau: State and county quick facts (2008-2012)

c U.S. Census Bureau Data 2010

d U.S. Census Bureau: State and county quick facts (2013) 
Comparing the demographics of the sampled population in both counties to their respective census data, age and education levels varied widely. Such variation is common in survey data and are mostly a result of non-responses which usually stems from sample self-selection. Moreover, the eligibility criteria of our sampling and the source of sample data for this study may have accounted for the variations in demographic characteristics that existed between the eligible respondent population and the county population as a whole. Based on the survey eligibility criteria and source of sampled population data, it was very likely that our sample will be older, owned a home and highly educated.

Table 5.4, depicts the expected and actual population shares required for the demographic categories (education and age) over or under sampled. No attempt was made to weight the opinions expressed by the sampled population to reflect the county demographics in the final mixed logit model. As a result, the opinions expressed by respondents in the two counties do not reflect that of households throughout the state of West Virginia. A formal comparison of multinomial logit models weighted to account for sampling bias in each county population relative to unweighted model will be presented later in the discussion section.

Oversampling of older and highly educated respondents are common in choice experiment survey studies (Firestone \& Kempton, 2007; Popkin, et al., 2013). Using households as the unit of analysis, Popkin, et al. (2013) found the differences of about 3\% between the unweighted and weighted sampled population with respect to demographic variables such as age and education level. 
Table 5.4. Expected sample size vs. actual sample size based on age and education level

\begin{tabular}{|c|c|c|c|c|}
\hline & \multicolumn{2}{|c|}{ Monongalia County } & \multicolumn{2}{|c|}{ Grant County } \\
\hline & \multicolumn{2}{|r|}{$\begin{array}{c}\text { Probability } \\
\text { Sampling Method } \\
( \pm 5)\end{array}$} & \multicolumn{2}{|r|}{$\begin{array}{c}\text { Probability } \\
\text { Sampling Method: } \\
( \pm 5 \%)\end{array}$} \\
\hline & $\begin{array}{c}\text { Final } \\
\text { Sample Size } \\
\text { (\% of Final } \\
\text { Sample) }\end{array}$ & $\begin{array}{c}\text { Expected } \\
\text { Population Share } \\
\text { Required } \\
\text { (\% of County } \\
\text { demographic) } \\
\end{array}$ & $\begin{array}{c}\text { Final Sample } \\
\text { Size } \\
\text { (\% of Final } \\
\text { Sample) }\end{array}$ & $\begin{array}{l}\text { Expected Population } \\
\text { Share Required } \\
\text { (\% of County } \\
\text { demographic) }\end{array}$ \\
\hline $\begin{array}{l}\text { Age } 25 \text { to } 64 \\
\text { Bachelors or } \\
\text { Higher }\end{array}$ & $82(26.3 \%)$ & $112(29.6 \%)$ & $66(17.0 \%)$ & $31(8.8 \%)$ \\
\hline $\begin{array}{l}\text { Age } 25 \text { to } 64 \text { Less } \\
\text { Than Bachelors }\end{array}$ & 67 (21.5\%) & $200(52.6 \%)$ & $153(39.3 \%)$ & $232(65.7 \%)$ \\
\hline $\begin{array}{c}\text { Age } 65 \text { Plus } \\
\text { Bachelors or } \\
\text { Higher }\end{array}$ & $106(34.0 \%)$ & $11(2.9 \%)$ & $38(10.0 \%)$ & $9(2.5 \%)$ \\
\hline $\begin{array}{c}\text { Age } 65 \text { Plus Less } \\
\text { Than Bachelors } \\
\end{array}$ & 57 (18.3\%) & 57 (14.9\%) & $132(33.9 \%)$ & $82(23 \%)$ \\
\hline $\begin{array}{c}\text { Number of } \\
\text { Respondents }\end{array}$ & 312 & 380 & 389 & 354 \\
\hline
\end{tabular}

In order to account for self-selection bias in the WTP calculations, consideration was given to putting weights based on age and education levels which varied widely in survey respondents compared to census data. The sampled populations in both county models were weighted based on age and education level. In Monongalia County, the population within the age group 25 to 64 years with less than a bachelor degree education level were under sampled by about $32 \%$, while the older age group (65 year and higher) with bachelor's degree or higher were over sampled by more than $31 \%$ relative to the county level data. In the Grant County model, all four age-education combination categories were either over sample or under sampled as presented in Table 5.5.

Weighting the data to reflect the population demographic statistics from census data prior to WTP calculations implies that the age and education groupings from the sampled populations 
preferences and opinions reflects the same groupings from the total population. For this study, only the estimation of consumers' WTP for the attributes of renewable and alternative electricity were weighted against age and education levels to reflect the population demographics in both counties. As a result, modeling of preferences and opinions were restricted to only our sampled population. Table 5.5 presents a summary of how the sampled population in both counties were weighted against age and education levels.

Table 5.5. Summary of weighting characteristics of populations.

\begin{tabular}{|c|c|c|c|c|c|c|}
\hline \multirow[b]{2}{*}{$\begin{array}{l}\text { Age and Education } \\
\text { Levels }\end{array}$} & \multicolumn{3}{|c|}{$\begin{array}{c}\text { Monongalia } \\
\text { County }\end{array}$} & \multicolumn{3}{|c|}{$\begin{array}{c}\text { Grant } \\
\text { County }\end{array}$} \\
\hline & $\begin{array}{c}\text { Target } \\
\text { Population } \\
\% \text { (County) }\end{array}$ & $\begin{array}{c}\text { Actual } \\
\text { Sample } \\
\text { Population } \\
\% \\
\end{array}$ & $\begin{array}{c}\text { Weights } \\
\text { (Target/ } \\
\text { Actual) }\end{array}$ & $\begin{array}{c}\text { Target } \\
\text { Population } \\
\% \text { (County) }\end{array}$ & $\begin{array}{c}\text { Actual } \\
\text { Sample } \\
\text { Population } \\
\% \\
\end{array}$ & $\begin{array}{l}\text { Weights } \\
\text { (Target/ } \\
\text { Actual) }\end{array}$ \\
\hline $\begin{array}{l}\text { Age } 25 \text { To } 64 \\
\text { Bachelors or } \\
\text { Higher }\end{array}$ & $30 \%$ & $26 \%$ & 1.13 & $9 \%$ & $17 \%$ & 0.52 \\
\hline $\begin{array}{l}\text { Age } 25 \text { To } 64 \text { Less } \\
\text { Than Bachelors }\end{array}$ & $53 \%$ & $21 \%$ & 2.45 & $66 \%$ & $39 \%$ & 1.67 \\
\hline $\begin{array}{c}\text { Age } 65 \text { Plus } \\
\text { Bachelors or } \\
\text { Higher } \\
\end{array}$ & $3 \%$ & $34 \%$ & 0.09 & $3 \%$ & $10 \%$ & 0.26 \\
\hline $\begin{array}{c}\text { Age } 65 \text { Plus Less } \\
\text { Than Bachelors }\end{array}$ & $15 \%$ & $18 \%$ & 0.82 & $23 \%$ & $34 \%$ & 0.68 \\
\hline
\end{tabular}

aData Source: Decennial Census Data (2000) from the National Center for Higher Education Management Systems.

\subsection{Familiarity with West Virginia's Alternative and Renewable Portfolio Standard and Electricity Generation in General.}

The first section of the survey had questions that sought to determine respondents' eligibility to participate in the survey and their average monthly electricity bill. The average monthly electricity bill was asked in order to determine if the two counties average electricity consumption widely differed. Also, the average monthly electricity bill a respondent pays may influence their WTP for additional premium on top of their bill for a cleaner electricity source. This hypothesis will 
be tested in the modeling of preferences and utility. Figure 5.1 depicts responses to the question on respondents' average monthly electricity bill. The mean average monthly electricity bill of the population surveyed in both counties were the same. Both counties had an almost identical percentages (27\%-28\%) of the surveyed population that fell within the mean range. Based on Figure 5.1, it can be assumed that on the average, electricity consumption in both counties does not widely differ from each other.

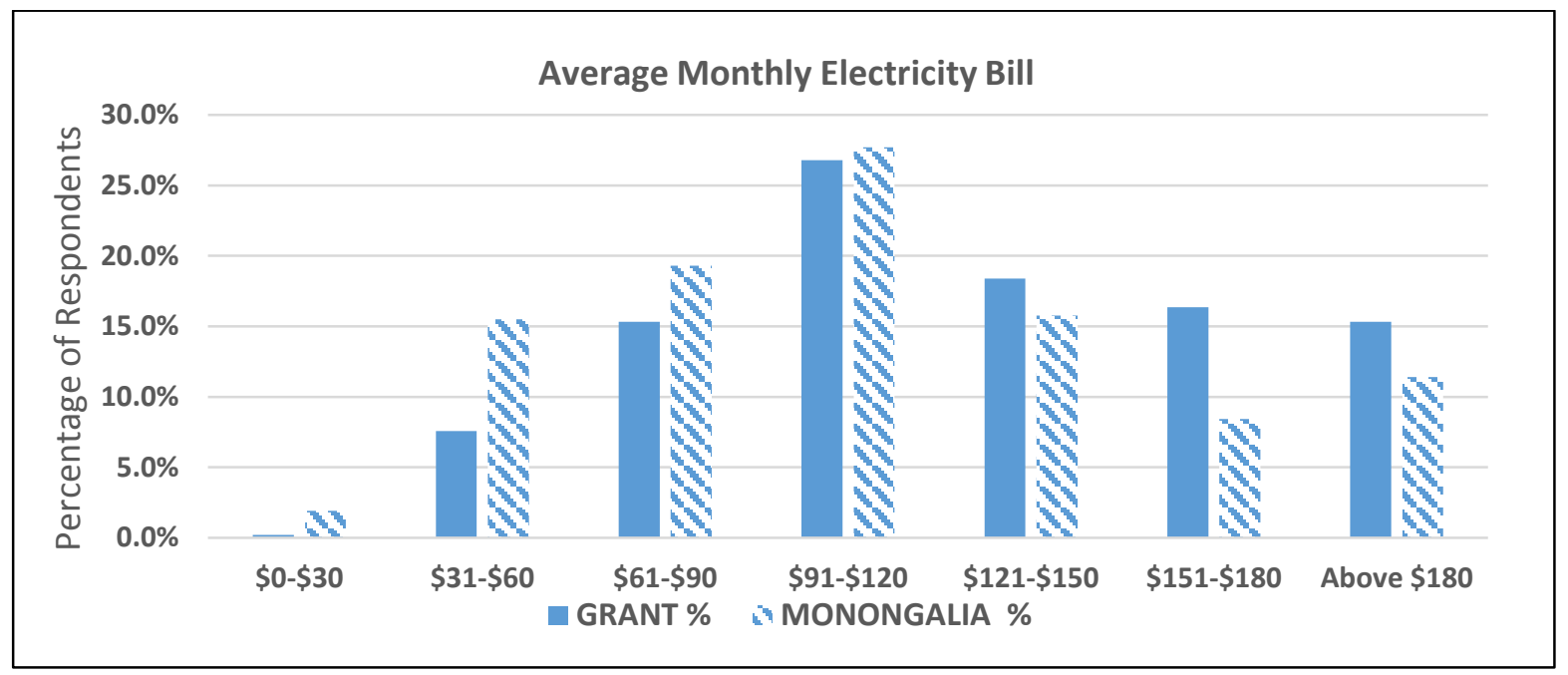

Figure 5.1. Responses to survey question on average monthly electricity bill.

At the time this survey was implemented, the West Virginia ARPS was still in place and plans to repeal the policy had not gained traction. As a result, the second section of the survey included questions \#4 to \#6 about respondents' familiarity with the adopted ARPS in West Virginia, support for the ARPS mandate, and knowledge on how electricity is generated from both renewable and non-renewable energy sources in general. Table 5.6 presents the results to question \#4 on respondents' familiarity with the ARPS adopted in West Virginia. The survey described the mandate before asking respondents about their familiarity with the mandate. 
Table 5.6. Response to survey question \#4: How familiar are you with the "Alternative and Renewable Energy Portfolio Standard"?

\begin{tabular}{|l|c||c|}
\hline Level of Familiarity & $\begin{array}{c}\text { Monongalia County } \\
\text { (n=376) }\end{array}$ & $\begin{array}{c}\text { Grant County } \\
\text { (n=496) }\end{array}$ \\
\hline $\begin{array}{l}\text { Had not heard of it until this } \\
\text { survey }\end{array}$ & $56 \%$ & $59 \%$ \\
\hline Slightly familiar & $20 \%$ & $18 \%$ \\
\hline Somewhat familiar & $13 \%$ & $15 \%$ \\
\hline Moderately familiar & $8 \%$ & $5 \%$ \\
\hline Very familiar & $3 \%$ & $3 \%$ \\
\hline
\end{tabular}

A majority of the survey respondents in both counties (at least 56\%) indicated they had not heard of the portfolio standard prior to survey participation. The percentage of respondents at each familiarity level in both counties closely resembled each other. The disparity between the two counties at any of the familiarity level was not more than 3\% (Table 5.6). The most unexpected part of this result was the disconnect that existed between the education level of the surveyed population in Monongalia County and familiarity with the ARPS mandate. Majority of the surveyed population (56\%) in Monongalia County had completed at least a 4 year college education. Yet, only $11 \%$ of the surveyed population were moderately to very familiar with the ARPS mandate. As a result of this disconnect that existed, it was surprising to see that the education level variable in consumers' utility model that will be presented later was not statistically significant in either county. 
After the ARPS mandate was introduced and familiarity level was asked, respondents support for the ARPS mandate was sought in question \#5. Result of respondents' support for the mandate is presented in Table 5.7. A substantial number of the surveyed population in both counties were not sure about their support for the mandate. A higher percentage of respondents in the Monongalia County surveyed population (41\%) supported the ARPS mandate. On the other hand, just under a third of the surveyed population in Grant County supported the mandate.

Table 5.7. Response to survey question \#5: Do you support this mandate?

\begin{tabular}{|l|c||c|}
\hline Response & $\begin{array}{c}\text { Monongalia County } \\
(\mathbf{n = 3 7 5 )}\end{array}$ & $\begin{array}{c}\text { Grant County } \\
(\mathbf{n = 4 9 4 )}\end{array}$ \\
\hline Yes, I support the mandate & $41 \%$ & $30 \%$ \\
\hline No, I do not support the mandate & $24 \%$ & $22 \%$ \\
\hline Not sure & $35 \%$ & $48 \%$ \\
\hline
\end{tabular}

In order to make any meaningful interpretation of a respondent's preferences and WTP for renewable electricity, it was important to assess whether the population being surveyed are familiar with how electricity is generated from the various types of energy sources that were presented in the choice experiment section of this survey. Since the survey was not conducted as an in-person interview, a lower level of familiarity with how the various energy sources are converted into electricity will pose great challenges to the validity of responses on the choice experiment questions. The most important challenge was the respondents' ability to understand the attribute of electricity generation that they are will be comparing in order to choose between options presented to them in the choice experiment section. Understanding attributes within the options given in the choice experiment section require some level of familiarity with how electricity is generated using various energy sources. Table 5.8 presents the surveyed populations' responses 
to their level of familiarity with how electricity is generated using coal, natural gas and wind turbines.

Table 5.8. Response to survey question \#6: What is your level of familiarity on how each of these energy sources is converted into electricity?

\begin{tabular}{|l|c|c|c||c|c|c|}
\hline & \multicolumn{2}{|c|}{ Monongalia County (\%) } & \multicolumn{3}{c|}{ Grant County (\%) } \\
\hline Level of Familiarity & $\begin{array}{c}\text { Coal } \\
\text { (n=373) }\end{array}$ & $\begin{array}{c}\text { Natural } \\
\text { Gas } \\
\text { (n=367) }\end{array}$ & $\begin{array}{c}\text { Wind } \\
(\mathbf{n = 3 6 5 )}\end{array}$ & $\begin{array}{c}\text { Coal } \\
(\mathbf{n = 4 9 0 )}\end{array}$ & $\begin{array}{c}\text { Natural } \\
\text { Gas } \\
(\mathbf{n = 4 8 2})\end{array}$ & $\begin{array}{c}\text { Wind } \\
\text { (n=485) }\end{array}$ \\
\hline Highly Familiar & $48 \%$ & $23 \%$ & $18 \%$ & $49 \%$ & $16 \%$ & $21 \%$ \\
\hline $\begin{array}{l}\text { Moderate or Medium } \\
\text { Familiarity }\end{array}$ & $35 \%$ & $40 \%$ & $35 \%$ & $35 \%$ & $34 \%$ & $40 \%$ \\
\hline Low Familiarity & $13 \%$ & $29 \%$ & $37 \%$ & $11 \%$ & $31 \%$ & $29 \%$ \\
\hline Not Familiar & $4 \%$ & $8 \%$ & $11 \%$ & $5 \%$ & $18 \%$ & $9 \%$ \\
\hline
\end{tabular}

The majority of surveyed respondents from both counties (83\% - 84\%) were highly to moderately familiar with how coal, as an energy source is converted to electricity. A higher percentage of the population surveyed in Monongalia County (63\%) compared to Grant County (50\%) were highly to moderately familiar with how natural gas is converted into electricity. In general, the Grant County surveyed population were much more familiar (moderate to highly familiar) with electricity generated using wind turbines compared to the surveyed population in Monongalia County. This result was not surprising given that Grant County is one of the few counties with an existing wind farm facility in West Virginia. Even though more than half of the surveyed population in Monongalia County were moderately to highly familiar (53\%) with electricity generated from wind, no wind farm currently exists within the county. The closest wind farm is within the state of Pennsylvania, but the turbines can be seen on the mountainous ridges from some parts of Monongalia County. 
A central objective of this survey was to estimate the value that survey respondents place on proximity as an attribute of a renewable or alternative electricity. In order to explain the influence of proximity on an individual's choice, it was important to have an idea on how the frequent sighting of an existing electricity generation facility impacted choices respondents made in the choice experiment section. Proximity as an attribute of electricity generation source, was presented as both visual and distance measures from the respondents' current residence. As a result, the frequency of sighting an existing coal or wind electricity generation facility was assessed by asking respondents the question; "How often do you notice a coal power plant or wind turbines?". Respondents were asked about their frequency of sighting these two types of power generation facilities, both from home and away from home. Table 5.9 presents results from survey questions \#7 and \#8 which sought to determine respondents' frequency of sighting a coal-fired power plant and wind turbine in Monongalia and Grant Counties.

Table 5.9. Summary of responses to survey questions \#7 and \#8: How often do you notice wind turbines or a coal power plant at the following locations?

\begin{tabular}{|c|c|c|c|c|c|c|c|c|}
\hline \multirow{3}{*}{$\begin{array}{l} \\
\text { Frequency } \\
\text { of Sighting }\end{array}$} & \multicolumn{4}{|c|}{ Monongalia County } & \multicolumn{4}{|c|}{ Grant County } \\
\hline & \multicolumn{2}{|c|}{ At Home } & \multicolumn{2}{|c|}{ Away from Home } & \multicolumn{2}{|c|}{ At Home } & \multicolumn{2}{|c|}{ Away from Home } \\
\hline & $\begin{array}{c}\text { Coal } \\
\text { Power } \\
\text { Plant } \\
(n=352) \\
\end{array}$ & $\begin{array}{c}\text { Wind } \\
\text { Turbines } \\
(\mathrm{n}=351)\end{array}$ & $\begin{array}{c}\text { Coal } \\
\text { Power } \\
\text { Plant } \\
(n=370)\end{array}$ & $\begin{array}{c}\text { Wind } \\
\text { Turbines } \\
\text { (n=371) }\end{array}$ & $\begin{array}{c}\text { Coal } \\
\text { Power } \\
\text { Plant } \\
(n=462)\end{array}$ & $\begin{array}{c}\text { Wind } \\
\text { Turbines } \\
(\mathrm{n}=459)\end{array}$ & $\begin{array}{c}\text { Coal } \\
\text { Power } \\
\text { Plant } \\
(n=470) \\
\end{array}$ & $\begin{array}{c}\text { Wind } \\
\text { Turbines } \\
(\mathrm{n}=474)\end{array}$ \\
\hline Frequently & $27 \%$ & $11 \%$ & $26 \%$ & $25 \%$ & $35 \%$ & $58 \%$ & $19 \%$ & $50 \%$ \\
\hline Sometimes & $22 \%$ & $13 \%$ & $59 \%$ & $63 \%$ & $24 \%$ & $12 \%$ & $62 \%$ & $43 \%$ \\
\hline Never & $51 \%$ & $77 \%$ & $15 \%$ & $13 \%$ & $41 \%$ & $29 \%$ & $19 \%$ & $7 \%$ \\
\hline
\end{tabular}


As shown in Table 5.9, a higher number of survey respondents in Grant County see wind turbines and coal-fired power plants frequently or sometimes when at home compared to survey respondents in Monongalia County. Even though the only wind farm within sight from some part of Monongalia County is located along the ridges of a neighboring county in Pennsylvania, an unusually high number of surveyed respondents $(88 \%)$ indicated that they sometimes or frequently see wind turbines when they are away from home. An overwhelming majority of the surveyed population in Grant County sometimes or frequently noticed wind turbines when away from home. At least $80 \%$ of the surveyed population in both counties indicated that they sometimes or frequently notice a coal-fired power plant when away from home.

\subsection{Preferences and Attitudes towards the Electricity Generated from Alternative, Renewable and Non-Renewable Sources in West Virginia}

After evaluating the surveyed population's familiarity with the ARPS mandate and electricity generation in general, the next section of the survey (questions \#9 through \# 12) assessed respondents' attitudes, preferences, and opinions about the ARPS mandate. Respondents' opinions on the positive and negative impacts of electricity generation from various energy sources on the environment, landscape, jobs and property values were also sought in this section of the survey.

Table 5.10 depicts the opinions expressed by respondents on how the goals of the ARPS mandate can be achieved in the near short term (2015). In order to meet the ARPS mandate in the near short term, respondents were given two possible renewable electricity options (expand exiting wind farms or build new wind farms) and two alternative electricity generation options (convert existing coal-fired power plants to natural gas-fired plants or build new natural gas-fired power plant) that have the potential of being used to satisfy the ARPS mandate in the near short term. Respondents were asked about the level of priority that their electric utility provider (Mon 
Power for Monongalia County and Potomac Edison for Grant County) should place on each option given in order to satisfy the ARPS mandate in the near short term. The two wind options were rated by respondents in both counties as the options that should receive the highest priority by utility providers in order to satisfy the ARPS in the near short term.

Table 5.10. Response to survey question \#9: In your opinion, what strategies should Mon Power or Potomac Edison use to increase its renewable and alternative electricity generation capacity?

\begin{tabular}{|c|c|c|c|c|c|c|c|c|}
\hline & \multicolumn{4}{|c|}{ Monongalia County } & \multicolumn{4}{|c|}{ Grant County } \\
\hline & $\begin{array}{l}\text { Expand } \\
\text { Existing } \\
\text { Wind } \\
\text { Farm } \\
(\mathrm{n}=369)\end{array}$ & $\begin{array}{l}\text { Build } \\
\text { New } \\
\text { Wind } \\
\text { Farms } \\
(n=362)\end{array}$ & $\begin{array}{c}\text { Convert } \\
\text { Existing } \\
\text { Coal-fired } \\
\text { to Natural } \\
\text { gas-fired } \\
(n=364)\end{array}$ & $\begin{array}{c}\text { Build New } \\
\text { Natural } \\
\text { Gas -Fired } \\
\text { Plants } \\
(n=365)\end{array}$ & $\begin{array}{c}\text { Expand } \\
\text { Existing } \\
\text { Wind } \\
\text { Farm } \\
(\mathrm{n}=480)\end{array}$ & $\begin{array}{l}\text { Build } \\
\text { New } \\
\text { Wind } \\
\text { Farms } \\
(n=479)\end{array}$ & $\begin{array}{c}\text { Convert } \\
\text { Existing } \\
\text { Coal-fired } \\
\text { to Natural } \\
\text { gas-fired } \\
(n=482)\end{array}$ & $\begin{array}{c}\text { Build New } \\
\text { Natural } \\
\text { Gas -Fired } \\
\text { Plants } \\
(n=480)\end{array}$ \\
\hline High Priority & $44 \%$ & $36 \%$ & $28 \%$ & $35 \%$ & $41 \%$ & $37 \%$ & $19 \%$ & $33 \%$ \\
\hline Low Priority & $23 \%$ & $27 \%$ & $31 \%$ & $34 \%$ & $26 \%$ & $26 \%$ & $29 \%$ & $31 \%$ \\
\hline Do Not Use & $17 \%$ & $21 \%$ & $21 \%$ & $12 \%$ & $15 \%$ & $18 \%$ & $27 \%$ & $13 \%$ \\
\hline $\begin{array}{l}\text { No Idea/Do } \\
\text { not know }\end{array}$ & $16 \%$ & $16 \%$ & $20 \%$ & $19 \%$ & $19 \%$ & $19 \%$ & $25 \%$ & $24 \%$ \\
\hline
\end{tabular}

As depicted in Table 5.10, a slightly higher number of the surveyed population in Monongalia County (44\%) compared to Grant County (41\%) expressed that utility provider should place a higher priority on expanding existing wind farm to meet the ARPS requirement. At least a third of the surveyed population in both Monongalia County (36\%) and Grant County (37\%) expressed that utility providers should highly prioritize the option to build new wind farms to satisfy the ARPS mandate. Support for the option to highly prioritize the building of new natural gas-fired power plants in both Monongalia County (35\%) and Grant County (33\%) were comparable to survey respondents support for the option to build new wind farms in both counties.

The option for utility providers to highly prioritize the conversion of some existing coal-fired power plants into natural gas-fired power plants in order to satisfy the ARPS mandate received the 
least support in both counties. Only $28 \%$ and $18 \%$ of the surveyed population in Monongalia County and Grant County respectively supported the option of placing a high priority on the conversion of coal-fired power plants into natural gas-fired power plants in order for utility providers to meet the ARPs mandate.

Respondents' general attitudes towards electricity generation facilities that utilize coal, natural gas and wind as energy sources were assessed. As presented in table 5.11, this question used a five point Likert scale to assess each respondent's attitudes towards electricity generation facilities. The majority of the surveyed population in both counties expressed a very positive to somewhat positive attitude towards all the three electricity generation facility options presented to them. The surveyed population in Grant County expressed a much higher positive attitude (very positive to somewhat positive) towards coal-fired power plants (68\%) compared to the Monongalia County surveyed population (50\%).

Table 5.11. Response to survey question \#10: What are your general attitudes toward electricity generation facilities that utilize these sources of energy?

\begin{tabular}{|c|c|c|c|c|c|c|}
\hline & \multicolumn{3}{|c|}{ Monongalia County } & \multicolumn{3}{|c|}{ Grant County } \\
\hline & $\begin{array}{c}\text { Attitude } \\
\text { Towards } \\
\text { Coal-Fired } \\
\text { Power } \\
\text { Plants } \\
(n=371)\end{array}$ & $\begin{array}{c}\text { Attitude } \\
\text { Towards } \\
\text { Natural Gas- } \\
\text { Fired Power } \\
\text { Plants } \\
(n=370)\end{array}$ & $\begin{array}{c}\text { Attitude } \\
\text { Towards } \\
\text { Wind } \\
\text { Farms } \\
(n=370)\end{array}$ & $\begin{array}{c}\text { Attitude } \\
\text { Towards } \\
\text { Coal-Fired } \\
\text { Power } \\
\text { Plants } \\
(n=488)\end{array}$ & $\begin{array}{c}\text { Attitude } \\
\text { Towards } \\
\text { Natural Gas- } \\
\text { Fired Power } \\
\text { Plants } \\
(n=482)\end{array}$ & $\begin{array}{c}\text { Attitude } \\
\text { Towards } \\
\text { Wind } \\
\text { Farms } \\
(\mathrm{n}=485)\end{array}$ \\
\hline Very Positive & $30 \%$ & $19 \%$ & $26 \%$ & $47 \%$ & $18 \%$ & $28 \%$ \\
\hline $\begin{array}{l}\text { Somewhat } \\
\text { Positive }\end{array}$ & $20 \%$ & $35 \%$ & $27 \%$ & $21 \%$ & $33 \%$ & $26 \%$ \\
\hline Neutral & $22 \%$ & $32 \%$ & $22 \%$ & $19 \%$ & $35 \%$ & $21 \%$ \\
\hline $\begin{array}{l}\text { Somewhat } \\
\text { Negative }\end{array}$ & $17 \%$ & $10 \%$ & $12 \%$ & $10 \%$ & $8 \%$ & $13 \%$ \\
\hline Very Negative & $11 \%$ & $5 \%$ & $13 \%$ & $3 \%$ & $5 \%$ & $11 \%$ \\
\hline
\end{tabular}


Interestingly, the percentage of respondents who expressed a very positive to somewhat positive attitude towards wind turbines was very similar in both Grant (54\%) and Monongalia (53\%) Counties. Since Grant County has an existing wind farm and a majority of the sampled population indicated that they see wind turbines from their current residence, it was expected that a higher percentage of the Grant County respondents would have a negative attitude towards wind turbines compared to Monongalia County. In addition, the percentages of respondents who expressed somewhat negative to very negative attitude towards wind turbines in both counties were very similar (24\% and $25 \%)$.

From Table 5.11, approximately 54\% of the of the surveyed population in Monongalia County expressed a very positive to somewhat positive attitude towards a natural gas-fired power plant compared to $51 \%$ in Grant County. The percentage of the surveyed population in Monongalia County and Grant County who expressed a very negative to somewhat negative attitude towards a natural gas-fired power plant were $35 \%$ and $32 \%$, respectively. A slightly higher percentage of the surveyed population in Grant County (15\%) expressed a neutral attitude towards natural gas-fired power plants compared to the surveyed population in Monongalia County (13\%).

The last question of this section of the survey sought the opinions of the surveyed population on the positive and negative impacts of electricity generation from coal, wind and natural gas on a variety of environmental and economic impacts. Seven categories were presented to respondents and they included; impacts on job creation, air quality, view of the landscape, property value, climate change, wildlife and environment in general. Table 5.12 presents the results of opinions expressed on the positive impacts of the three electricity generation sources presented to respondents. The trend in responses on the question that sought respondents opinions on the 
positive impacts of the three electricity generation sources were similar for the surveyed population of the two counties in almost all categories presented.

For wind energy, the highest percentages of the respondents surveyed in Monongalia County perceived that air quality (73\%), climate change (51\%) and the environment in general (48\%) are positively impacted. Respondents in Monongalia County who knew enough to express opinions perceived that electricity generated from natural gas positively impacts landscape view (39\%), property value (34\%) and wildlife (39\%). In all seven categories presented to respondents in the survey, job creation was the only category that was perceived most respondents in Monongalia County (51\%) to be positively impacted by electricity generated from coal. The proportion of Monongalia County respondents who expressed that they do not know enough to answer the questions on the positive impacts of electricity generation sources ranged from $12 \%$ to $37 \%$ across the seven categories presented to them.

Compared to the Monongalia County surveyed population, much higher percentages of Grant County respondent (20\% to $40 \%$ ) indicated that they do not know enough to express an opinion on which electricity generation source has the most positive impacts on each of the seven categories presented to them. The majority of the surveyed population in Grant County perceived that electricity generated from coal has a positive impact (62\%) on job creation. For wind energy, Grant County respondents perceived positive impacts for air quality (63\%), climate change (39\%) and environment (34\%). Similar to the Monongalia County surveyed population, Grant County respondents perceived that landscape view (39\%), property value (34\%) and wildlife (30\%) were most positively impacted by electricity generated from natural gas. 
Table 5.12. Response to survey question \#11: In your opinion, which of the following electricity generation sources have the most positive impact on the following?

\begin{tabular}{|c|c|c|c|c|c|c|c|c|}
\hline \multirow[b]{2}{*}{ Item or Positive Impact } & \multicolumn{4}{|c|}{$\begin{array}{c}\text { Monongalia County } \\
\mathrm{N}=370\end{array}$} & \multicolumn{4}{|c|}{$\begin{array}{c}\text { Grant County } \\
N=487\end{array}$} \\
\hline & Coal & $\begin{array}{c}\text { Natural } \\
\text { Gas }\end{array}$ & Wind & $\begin{array}{l}\text { Do Not } \\
\text { Know } \\
\text { Enough to } \\
\text { Answer }\end{array}$ & Coal & $\begin{array}{l}\text { Natural } \\
\text { Gas }\end{array}$ & Wind & $\begin{array}{c}\text { Do Not } \\
\text { Know } \\
\text { Enough to } \\
\text { Answer }\end{array}$ \\
\hline Job creation & $51 \%$ & $22 \%$ & $4 \%$ & $23 \%$ & $62 \%$ & $8 \%$ & $8 \%$ & $23 \%$ \\
\hline Air quality & $5 \%$ & $11 \%$ & $73 \%$ & $12 \%$ & $5 \%$ & $12 \%$ & $63 \%$ & $20 \%$ \\
\hline View of the landscape & $14 \%$ & $39 \%$ & $24 \%$ & $24 \%$ & $15 \%$ & $39 \%$ & $21 \%$ & $25 \%$ \\
\hline Property values & $10 \%$ & $34 \%$ & $18 \%$ & $37 \%$ & $14 \%$ & $34 \%$ & $13 \%$ & $40 \%$ \\
\hline Climate change & $7 \%$ & $9 \%$ & $51 \%$ & $32 \%$ & $9 \%$ & $10 \%$ & $39 \%$ & $41 \%$ \\
\hline Wildlife (Birds \& Bats) & $13 \%$ & $39 \%$ & $19 \%$ & $29 \%$ & $15 \%$ & $30 \%$ & $19 \%$ & $36 \%$ \\
\hline Environment in general & $9 \%$ & $20 \%$ & $48 \%$ & $23 \%$ & $11 \%$ & $23 \%$ & $34 \%$ & $31 \%$ \\
\hline
\end{tabular}

Respondents' opinions on the potential negative impacts of electricity generated from natural gas, wind and coal were also assessed and the results are presented in Table 5.13. Not surprisingly, the highest percentages of the Monongalia County surveyed population perceived electricity generated from coal as the source with the most negative impacts on air quality (71\%) , climate change (47\%), and the environment in general (51\%). Electricity generated from wind was also perceived to be the generation source with the most negative impacts on job creation (42\%), view of landscape (43\%), property values (27\%), and wildlife (53\%) within the Monongalia County respondents.

Within the Grant County surveyed population, higher percentages of the respondents perceived that air quality (56\%), climate change (32\%), and the environment in general (38\%) are most negatively impacted by electricity generated from coal. Also, a higher percentage of the Grant County respondents perceived that job creation (39\%), landscape view (47\%), property value (32\%) and wildlife (49\%) are most negatively impacted by electricity generated from wind. 
Given that the coal mining industry is a major source of employment in West Virginia, opinions expressed on the negative impacts of electricity generated from wind on job creation by the surveyed populations in both counties were not surprising. A common theme of support for coal as an energy source for electricity generation and its impact on job creation in West Virginia seems to dominate the comments provided by the respondents in both counties (Monongalia County: 23 out of 61 comments and Grant County: 15 out of 37 comments) on the questions that sought their opinions on the positive and negative impacts of the three types of electricity generation sources presented to them. Some of the comments included: (1) "the most negative impact is the EPA regulations killing jobs in WV. Needed Jobs are tough to come by"; (2) "Air quality is important but how gar we go depends on how many employees we want to put out of work. I am sure the EPA has a good reason for clean air requirement. Clean air and no food is unnecessary need in our life time"; (3) "... if coal-fired plants are taken away from this area the economy will suffer enormously."

Table 5.13. Response to survey question \#12: In your opinion, which of the following electricity generation sources have the most negative impact on the following?

\begin{tabular}{|c|c|c|c|c|c|c|c|c|}
\hline \multirow[b]{2}{*}{$\begin{array}{c}\text { Item or Negative } \\
\text { Impact }\end{array}$} & \multicolumn{4}{|c|}{$\begin{array}{l}\text { Monongalia County } \\
(\mathrm{N}=368)\end{array}$} & \multicolumn{4}{|c|}{$\begin{array}{l}\text { Grant County } \\
(\mathrm{N}=472)\end{array}$} \\
\hline & Coal & $\begin{array}{c}\text { Natural } \\
\text { Gas }\end{array}$ & Wind & $\begin{array}{l}\text { Do Not } \\
\text { Know } \\
\text { Enough to } \\
\text { Answer }\end{array}$ & Coal & $\begin{array}{c}\text { Natural } \\
\text { Gas }\end{array}$ & Wind & $\begin{array}{l}\text { Do Not } \\
\text { Know } \\
\text { Enough to } \\
\text { Answer }\end{array}$ \\
\hline Job creation & $13 \%$ & $6 \%$ & $42 \%$ & $39 \%$ & $13 \%$ & $11 \%$ & $39 \%$ & $37 \%$ \\
\hline Air quality & $71 \%$ & $3 \%$ & $5 \%$ & $20 \%$ & $56 \%$ & $7 \%$ & $8 \%$ & $29 \%$ \\
\hline View of the landscape & $27 \%$ & $7 \%$ & $43 \%$ & $23 \%$ & $20 \%$ & $8 \%$ & $47 \%$ & $25 \%$ \\
\hline Property values & $23 \%$ & $10 \%$ & $27 \%$ & $40 \%$ & $17 \%$ & $9 \%$ & $32 \%$ & $42 \%$ \\
\hline Climate change & $47 \%$ & $6 \%$ & $7 \%$ & $39 \%$ & $32 \%$ & $8 \%$ & $10 \%$ & $50 \%$ \\
\hline Wildlife (Birds \& Bats) & $13 \%$ & $5 \%$ & $53 \%$ & $30 \%$ & $8 \%$ & $6 \%$ & $49 \%$ & $37 \%$ \\
\hline Environment in general & $51 \%$ & $7 \%$ & $10 \%$ & $32 \%$ & $38 \%$ & $8 \%$ & $14 \%$ & $41 \%$ \\
\hline
\end{tabular}


The percentage of respondents who did not know enough to answer the question on the electricity generation source associated with the most negative impact on each of the seven categories that were presented were substantial in both counties (at least $20 \%$ for each impact). In all the seven categories presented to respondents, electricity generated from natural gas scored the least on perceived negative impacts. Even though this results cannot be directly interpreted as the generation source with the most positive impacts; it was consistent with the opinions expressed by respondents in the previous question on positive impacts of electricity generation sources.

Electricity generated from natural gas consistently scored first (three times) or second (four times) on the perceived positive impacts in all seven categories presented in both counties.

The fourth section of the survey presented a series of statements ranging from concerns about pollution associated with electricity generation, cost of electricity, and the opportunity to choose utility provider. Four of these statements were relevant in explaining respondent's opinions and attitudes towards electricity generated from cleaner sources of energy relative to coal. Table 5.14 presents the results on respondents' level of agreement to the statements presented to them in this section of the survey.

The vast majority of the respondents in both Monongalia County (72\%) and Grant County (86\%) agreed with the statement "For electricity, I am mainly concerned about how much I pay on my electricity bill". From an economic perspective, it was not surprising that a majority of the respondents agreed with this statement. Given that the cost electricity from renewable sources are relatively higher than electricity from coal, consumers will have to pay a premium for electricity generated from cleaner energy sources. 
Respondents were also asked whether they agree with two statements that touched on pollution and the need to invest in less polluting sources of electricity generation. The responses to these statements were used to assess the surveyed populations' attitudes and opinions on the need for renewable sources of energy in West Virginia. The statements on pollution and the need to invest in less polluting electricity generation sources to some degree also captured altruistic tendencies that may exist within the surveyed population.

A majority of the surveyed population in Monongalia County (72\%) agreed with the statement "I am concerned about pollution created by electricity generation". A much higher percentage of the population (82\%) agreed with the statement "It is important to invest in power plants that generate the least amount of pollution". Yet, less than $37 \%$ of the Monongalia County respondents agreed with the statement "I would be willing to pay more for electricity that is generated with less pollution than current energy sources (mainly coal)". 
Table 5.14. Response to survey question \#13: You are presented with a series of statements. Please indicate your strength of agreement or disagreement with each statement that best represents your opinion?

\begin{tabular}{|c|c|c|c|c|c|c|}
\hline & \multicolumn{3}{|c|}{ Monongalia County } & \multicolumn{3}{|c|}{ Grant County } \\
\hline$\underline{\text { Items }}$ & $\begin{array}{c}\text { Strongly to } \\
\text { Somewhat } \\
\text { Disagree }\end{array}$ & Neutral & $\begin{array}{c}\text { Strongly } \\
\text { to } \\
\text { Somewhat } \\
\text { Agree }\end{array}$ & $\begin{array}{c}\text { Strongly to } \\
\text { Somewhat } \\
\text { Disagree }\end{array}$ & Neutral & $\begin{array}{c}\text { Strongly to } \\
\text { Somewhat } \\
\text { Agree }\end{array}$ \\
\hline $\begin{array}{l}\text { For electricity, I am } \\
\text { mainly concerned about } \\
\text { how much I pay on my } \\
\text { electricity bill. }\end{array}$ & $\begin{array}{c}13 \% \\
(n=369)\end{array}$ & $\begin{array}{c}15 \% \\
(n=369)\end{array}$ & $\begin{array}{c}72 \% \\
(n=369)\end{array}$ & $\begin{array}{c}7 \% \\
(n=483)\end{array}$ & $\begin{array}{c}7 \% \\
(n=483)\end{array}$ & $\begin{array}{c}86 \% \\
(n=483)\end{array}$ \\
\hline $\begin{array}{l}\text { I am concerned about } \\
\text { pollution created by } \\
\text { electricity generation. }\end{array}$ & $\begin{array}{c}11 \% \\
(n=368)\end{array}$ & $\begin{array}{c}14 \% \\
(n=368)\end{array}$ & $\begin{array}{c}74 \% \\
(n=368)\end{array}$ & $\begin{array}{c}14 \% \\
(n=480)\end{array}$ & $\begin{array}{c}24 \% \\
(n=480)\end{array}$ & $\begin{array}{c}62 \% \\
(n=480)\end{array}$ \\
\hline $\begin{array}{l}\text { It is important to invest } \\
\text { in power plants that } \\
\text { generate the least } \\
\text { amount of pollution. }\end{array}$ & $\begin{array}{c}8 \% \\
(n=369)\end{array}$ & $\begin{array}{c}11 \% \\
(n=369)\end{array}$ & $\begin{array}{c}81 \% \\
(n=369)\end{array}$ & $\begin{array}{c}11 \% \\
(n=482)\end{array}$ & $\begin{array}{c}17 \% \\
(n=482)\end{array}$ & $\begin{array}{c}72 \% \\
(n=482)\end{array}$ \\
\hline $\begin{array}{l}\text { State and federal } \\
\text { governments have } \\
\text { adequate measures in } \\
\text { place to protect the } \\
\text { environment from } \\
\text { pollution generated by } \\
\text { power plants. }\end{array}$ & $\begin{array}{c}40 \% \\
(n=368)\end{array}$ & $\begin{array}{c}19 \% \\
(n=368)\end{array}$ & $\begin{array}{c}40 \% \\
(n=368)\end{array}$ & $\begin{array}{c}20 \% \\
(n=475)\end{array}$ & $\begin{array}{c}22 \% \\
(n=475)\end{array}$ & $\begin{array}{c}58 \% \\
(n=475)\end{array}$ \\
\hline $\begin{array}{l}\text { Each consumer should } \\
\text { be able to choose the } \\
\text { electricity generation } \\
\text { source that he or she } \\
\text { prefers. }\end{array}$ & $\begin{array}{c}24 \% \\
(n=367)\end{array}$ & $\begin{array}{c}25 \% \\
(n=367)\end{array}$ & $\begin{array}{c}51 \% \\
(n=367)\end{array}$ & $\begin{array}{c}18 \% \\
(n=476)\end{array}$ & $\begin{array}{c}21 \% \\
(n=367)\end{array}$ & $\begin{array}{c}61 \% \\
(n=367)\end{array}$ \\
\hline $\begin{array}{l}\text { I would be willing to } \\
\text { pay more for electricity } \\
\text { that is generated with } \\
\text { less pollution than } \\
\text { current energy sources } \\
\text { (mainly coal). }\end{array}$ & $\begin{array}{c}44 \% \\
(n=368)\end{array}$ & $\begin{array}{c}19 \% \\
(n=368)\end{array}$ & $\begin{array}{c}37 \% \\
(n=368)\end{array}$ & $\begin{array}{c}64 \% \\
(n=482)\end{array}$ & $\begin{array}{c}18 \% \\
(n=482)\end{array}$ & $\begin{array}{c}18 \% \\
(n=482)\end{array}$ \\
\hline
\end{tabular}


A similar trend in opinions were expressed by the respondents in Grant County. A majority of the Grant County surveyed population agreed they were concerned about the pollution created by electricity generation (62\%), and there is the need to invest in a less polluting electricity generation sources (72\%). A much lower percentage of the Grant County surveyed population (18\%) agreed with the statement "I would be willing to pay more for electricity that is generated with less pollution than current energy sources (mainly coal)". The disconnect that existed between concerns about pollution and WTP a premium for less polluting sources of electricity in both counties may be attributed to what economists refer to as the "free riding" effect. A clean environment (less air pollution) like any other public good lacks a clearly defined property right. As a result, there an incentive for a respondent to free ride on this attribute.

Such disconnect that exist between respondents' support for renewable and alternative sources of electricity and willingness to pay a premium for these sources of electricity was also evident in a similar study that assessed consumer's preferences and attitudes for energy efficiency across West Virginia by the Center for Business and Economic Research (2006). This study found only $24.1 \%$ of the population surveyed were willing to pay a premium for electricity products that utilized renewable and alternative energy, yet a higher percentage of the respondents (62.9\%) supported the idea that the state should encourage the establishment of more large scale wind farms as an economic development strategy.

The second question in section four of the survey (question \#17) informed respondents about the possible economic benefits that may be associated with renewable energy investments and sought their opinions on where (location) these economic benefits should be allocated. At least a half of the survey respondents in both counties believed that the economic benefits from renewable electricity investment should stay within the county in which the facility is located or 
within the state of West Virginia. A sizeable share of the respondents in Monongalia County (51\%) and Grant County (45\%) believed that it is important for the economic benefits from renewable electricity investment to stay within the immediate community where the facility is located. Less than half of the respondents from both counties believed the economic benefits from renewable electricity investments should benefit the nation as a whole. Table 5.15 presents a summary result of opinions expressed by the population surveyed in both counties on the economic benefits from renewable electricity investment.

Table 5.15. Response to survey question \#17: Investments in renewable and alternative electricity generation facilities have many economic benefits. In your opinion, where are these economic benefits important?

\begin{tabular}{|l|c|c|}
\hline & $\begin{array}{c}\text { Monongalia } \\
\text { County }\end{array}$ & Grant County \\
\hline $\begin{array}{l}\text { Within the immediate community } \\
\text { where the facility is located }\end{array}$ & $\begin{array}{c}51 \% \\
(\mathrm{n}=361)\end{array}$ & $\begin{array}{c}45 \% \\
(\mathrm{n}=489)\end{array}$ \\
\hline $\begin{array}{l}\text { Anywhere within the county where } \\
\text { the facility is located }\end{array}$ & $\begin{array}{c}53 \% \\
(\mathrm{n}=361)\end{array}$ & $\begin{array}{c}50 \% \\
(\mathrm{n}=489)\end{array}$ \\
\hline Within the state of West Virginia & $\begin{array}{c}67 \% \\
(\mathrm{n}=361)\end{array}$ & $\begin{array}{c}63 \% \\
(\mathrm{n}=489)\end{array}$ \\
\hline Nationally & $\begin{array}{c}45 \% \\
(\mathrm{n}=361)\end{array}$ & $\begin{array}{c}31 \% \\
(\mathrm{n}=489)\end{array}$ \\
\hline
\end{tabular}

In order to interpret the results of opinions expressed by the surveyed population and choices made in the choice experiment section of the survey, the last part of the survey sought information on demographic characteristics of respondents from both counties. These characteristics included gender, age, years of permanent residency in West Virginia, education level, housing status, income level and environmental organization affiliation. Table 5.16 presents a summary of the surveyed populations' responses to questions on demographics and individual characteristics. 
Table 5.16. Summary result of respondents' demographics and individual characteristics (survey questions \#18 through \#24)

\begin{tabular}{|l|c|c|}
\hline Percentage of females & $\begin{array}{c}\text { Monongalia County } \\
\text { Respondents }\end{array}$ & $\begin{array}{c}\text { Grant County } \\
\text { Respondents }\end{array}$ \\
\hline Median age (years) & $\begin{array}{c}52 \% \\
(\mathrm{n}=373)\end{array}$ & $\begin{array}{c}47 \% \\
(\mathrm{n}=496)\end{array}$ \\
\hline $\begin{array}{l}\text { Median years of permanent residency in } \\
\text { West Virginia }\end{array}$ & $\begin{array}{c}67 \mathrm{yrs} \\
64 \mathrm{yrs}\end{array}$ & All my life \\
\hline $\begin{array}{l}\text { Education (Percentage share with at least 2- } \\
\text { year college degree or education) }\end{array}$ & $\begin{array}{c}71 \% \\
(\mathrm{n}=371)\end{array}$ & $\begin{array}{c}42 \% \\
(\mathrm{n}=485)\end{array}$ \\
\hline Home owner & $\begin{array}{c}92 \% \\
(\mathrm{n}=370)\end{array}$ & $\begin{array}{c}93 \% \\
(\mathrm{n}=493)\end{array}$ \\
\hline $\begin{array}{l}\text { Currently or was a member of an } \\
\text { environmental organization }\end{array}$ & $\begin{array}{c}17 \% \\
(\mathrm{n}=367)\end{array}$ \\
\hline Median Household Income (per year) & $\$ 50,000-\$ 74,999$ & $\$ 35,000-\$ 49,999$ \\
\hline
\end{tabular}

At least $47 \%$ of the surveyed population in both counties were female. The median age of the surveyed population in Monongalia County (67 years) was slightly higher than the Grant County surveyed population. Figure 5.2 presents a detailed distribution respondents' age in both counties. The majority of the surveyed population in both counties were above sixty (60) years. The majority of the surveyed population in both counties indicated that they have lived in their respective counties as permanent residents for at least twenty years. Most of the Monongalia County surveyed population had a higher level of education compared to the Grant County surveyed population.

About $71 \%$ of the surveyed population in Monongalia County had completed at least a two (2) year college degree compared to $42 \%$ of the surveyed population in Grant County. A detailed analysis of education levels of the surveyed populations in both counties are presented in Table 5.17. 


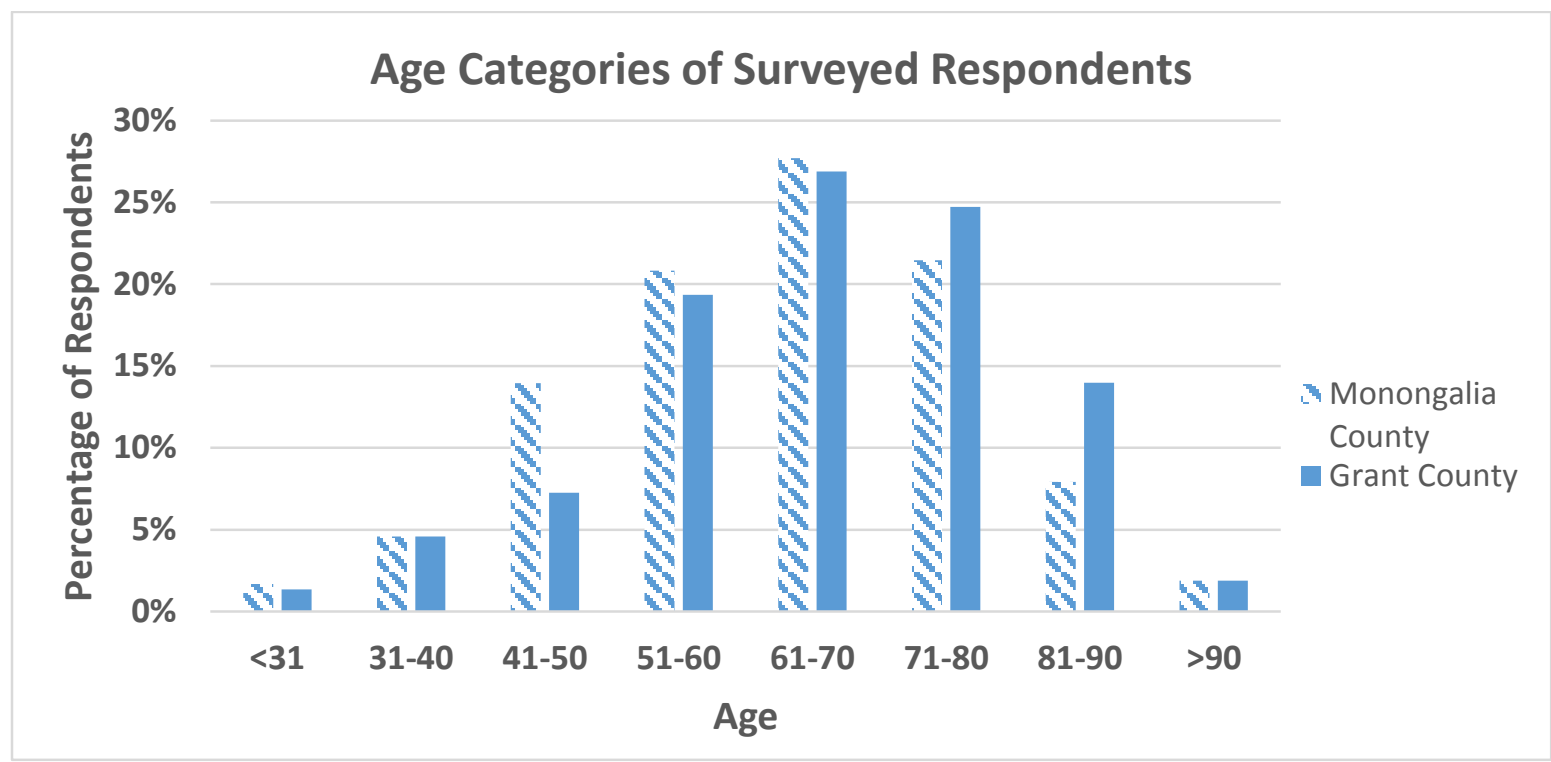

Figure 5.2. Respondents age distribution categories.

Table 5.17. Summary of education levels of respondents.

\begin{tabular}{|c|c|c|}
\hline & $\begin{array}{c}\text { Monongalia County } \\
(\mathbf{n = 3 7 1})\end{array}$ & $\begin{array}{c}\text { Grant County } \\
(\mathbf{n = 4 8 5})\end{array}$ \\
\hline Elementary School & $2 \%$ & $11 \%$ \\
\hline High School & $27 \%$ & $47 \%$ \\
\hline Associate Degree & $15 \%$ & $16 \%$ \\
\hline College Education & $26 \%$ & $16 \%$ \\
\hline Graduate School & $30 \%$ & $10 \%$ \\
\hline
\end{tabular}


Most of the population surveyed in both counties owned a home (at least 92\%). A higher number of the surveyed population in Monongalia County (17\%) indicated that they are current members or were members of an environmental organization compared to only $2 \%$ of the surveyed population in Grant County. The median household income range of the surveyed population in Monongalia County was higher $(\$ 50,000-\$ 74,999)$ than the Grant County $(\$ 35000-\$ 49,999)$ surveyed population. 


\section{Chapter 6}

\section{Choice Experiment Results and Willingness to Pay Estimation}

\subsection{Descriptive statistics of respondents' choices}

The total valid responses (individual responses) received and coded from Monongalia County and Grant County were 380 and 501, respectively. Each individual was randomly assigned to a single block out of 12 blocks. Each block of the choice design included three choice situations. Respondents were instructed to consider each choice situation presented independent of one another.

Approximately, 8\% (30 individuals) of the respondents who returned the survey from Monongalia County did not answer at least one of the three choice situations presented to them. As a result of missing responses to some of the survey questions (mostly socio-demographic characteristics), only 927 out of possible 1,069 completed choice situations were included in the

final choice model for Monongalia County. On the other hand, about 9\% (47 individuals) of the total responses received from Grant County did not answer at least one out of the three choice situations presented to them in the choice questions section of the survey. The final choice model for the Grant County surveyed population included 1,150 observations (choice situations) out of the possible 1,403 completed choice situations.

Table 6.1 presents a summary result of the choice experiment section. The summary statistics of choices made in the choice experiment section is based on the total usable responses (only answered choice situations) and not the final number of observations used in the final models for both counties. To simulate compliance with the West Virginia ARPS, respondents were given the option to choose between generating $10 \%$ of electricity supplied to their residence from either a 
natural gas-fired power plant or a wind farm. Majority of the respondents in both counties (at least $60 \%)$ chose electricity generated from wind. The choice trends of demographic groups that were over sampled (older and highly educated) were also assess and the results is presented in table 6.2.

Table 6.1. Summary statistics of energy choices made.

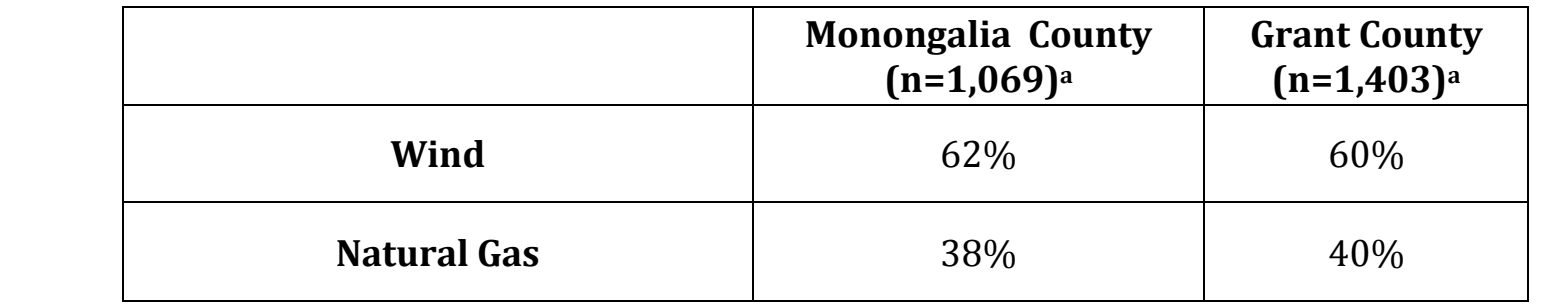

${ }^{\mathrm{a}}$ The total number of completed choice situations or observations (n) that was returned. Each respondent completed a maximum of three choice situations. Only 927 (Monongalia County) and 1150 (Grant County) were used in the final models.

Table 6.2. Choice trends based on respondents' education level and age

\begin{tabular}{|l|c|c|c||c|c|c|}
\cline { 2 - 7 } \multicolumn{1}{c|}{} & \multicolumn{3}{c||}{ Monongalia County } & \multicolumn{3}{c|}{ Grant County } \\
\hline Demographic Category & $\begin{array}{c}\text { Wind } \\
\text { Option }\end{array}$ & $\begin{array}{c}\text { Natural } \\
\text { Gas Option }\end{array}$ & $\begin{array}{c}\text { Number of } \\
\text { Choice } \\
\text { Situations }\end{array}$ & $\begin{array}{c}\text { Wind } \\
\text { Option }\end{array}$ & $\begin{array}{c}\text { Natural } \\
\text { Gas } \\
\text { Option }\end{array}$ & $\begin{array}{c}\text { Number of } \\
\text { Choice } \\
\text { Situations }\end{array}$ \\
\hline $\begin{array}{l}\text { Younger Respondents } \\
\text { (25yrs to 64yrs) }\end{array}$ & $66 \%$ & $34 \%$ & 441 & $61 \%$ & $39 \%$ & 653 \\
\hline $\begin{array}{l}\text { Older Respondents } \\
\text { (65 years and above) }\end{array}$ & $60 \%$ & $40 \%$ & 486 & $62 \%$ & $38 \%$ & 497 \\
\hline $\begin{array}{l}\text { High Education Level } \\
\text { (4 years College } \\
\text { Education \& above) }\end{array}$ & $65 \%$ & $35 \%$ & 558 & $57 \%$ & $43 \%$ & 311 \\
\hline $\begin{array}{l}\text { Low Education Level } \\
\text { (4 years College } \\
\text { Education) }\end{array}$ & $60 \%$ & $40 \%$ & 369 & $63 \%$ & $37 \%$ & 839 \\
\hline
\end{tabular}

a Number of choice situation is based on the choice situations used in the final models of both counties 
Based on the results presented in table 6.2, it can be asserted that there were no dramatic differences observed between the choices made by the younger and older sub-populations within each county's sampled population. Similarly, the highly educated population in both counties did not overwhelmingly choose the wind option over natural gas option to any greater degree than the respective lower education level sub-population in each county. Based on these observations, it can be asserted that over sampling of older and highly educated respondents in both counties will not dramatically impact the final unweighted utility models. As indicated earlier, subsequent WTP computations were weighted to account for demographic disparities. As a result, economic implications from this study were extrapolated to represent the total households of the respective counties.

Econometric models were developed to explain factors that influenced respondent's choices to generate electricity to meet the ARPS. Variables used in the model to explain respondents' choices are presented in Table 6.3. Customary to economic theory, the parameter estimate for additional fees (premiums) required to supply $10 \%$ of electricity from wind or natural gas, was expected to be negative. Based on the proximity hypothesis, it would have been reasonable to expect that respondents' utility will increase as the proximity of the generation source to their current residence decreased. However, how proximity as an attribute of electricity generation source interacts with the type of energy source or power plant is unclear. Moreover, prior experience with a type of electricity generation source and how it influences utility derived from a choice was also unclear. Monongalia County has three coal power plants, while Grant County has two coal power plants and a wind farm.

The variable "average bill" (average electricity bill per month) was expected to negatively influence utility derived from a choice that requires additional fees on top of the monthly electricity 
bill. Similarly, respondents who expressed that they were concerned about their electricity bill when it comes to electricity were expected to derive a lower utility from a choice of a renewable or alternative electricity relative to respondents with no such concerns. As a result the variable that represented respondents' concern about their electricity bill (concern_bill) when it came to electricity choice was also expected to negatively influence utility derived from a choice of renewable electricity source.

The frequency of sighting a type of electricity generation facility from a respondent's residence was expected to influence the choice an individual will make between wind and natural gas. How the frequency of sighting a type of generation source (wind farm, coal power plant and natural gasfired power plant) from a respondent's current residence influenced choice and utility was unclear and no prior expectation was placed on the variable.

Some variables on individuals' perceptions, attitudes and preferences for renewable electricity and the environment in general were also included in the model. Respondents' perceptions on the need to invest in less polluting sources of electricity (invest_less pollution) were also included as a variable in the utility model. It was expected that respondents who believed that the state of West Virginia should invest in lower polluting electricity generation sources were more likely to choose wind over natural gas. A respondent's general attitude towards electricity generated from a coalfired power plant was included in the model. It was expected that individuals with negative attitude towards electricity generated from a coal-fired power plant (neg attitude coal) were expected to be more likely to choose wind over coal. Given the seven categories of possible negative impacts of electricity generation sources that ranged from the environment, economy and landscape, the percentage of times an individual selects each of the three electricity generation sources as the source with the most negative impacts on the categories presented was used to 
explain respondent's choice. It was expected that the higher the percentage number of times a generation source was perceived as the source with the most negative impacts among the seven categories, the likelihood decreases for a respondent choosing that particular choice among a choice set.

Environmental affiliation (env affiliation) was also included to test whether being part of a proenvironmental group influenced the choice between electricity generated from wind or natural gas. Since the impacts of the two electricity generation sources (wind and natural gas options) included in choice profiles at any proximity level were not quantified, an a-prior expectation of this variable was unreasonable.

Socio-demographic characteristics of respondents were included in the model. These variables included age, education level (4-year college), and gender. No a priori expectations were placed on the signs of estimated coefficients for these variables. The income levels of respondents were recorded but not included in the final model. A significant number of respondents did not provide their income level. Moreover, economic theory suggests that education level is highly correlated with income level. Including education level in our model to some degree captures income level of respondents. 
Table 6.3. Definitions of variables included in estimated models.

\begin{tabular}{|c|c|c|c|c|c|}
\hline Variable & Description & Coding & Mean & Min & Max \\
\hline $\begin{array}{l}\text { WIND_MODERATE }^{a} \\
n=584(\mathrm{M}) \\
n=707(\mathrm{G})\end{array}$ & $\begin{array}{l}\text { Electricity provided by wind turbines at a moderate } \\
\text { distance from current residence. }\end{array}$ & $\begin{array}{l}-1=\text { near residence (reference case) } \\
1=\text { attribute level present } \\
0=\text { attribute level not present }\end{array}$ & $\begin{array}{l}0.086(\mathrm{M}) \\
-0.023(\mathrm{G})\end{array}$ & -1 & 1 \\
\hline $\begin{array}{l}\text { WIND_FAR }^{\mathbf{a}} \\
n=584(\mathrm{M}) \\
n=707(\mathrm{G})\end{array}$ & $\begin{array}{l}\text { Electricity provided by wind turbines at a distance far } \\
\text { from current residence. }\end{array}$ & $\begin{array}{l}-1=\text { near residence (reference case) } \\
1=\text { attribute level present } \\
0=\text { attribute level not present }\end{array}$ & $\begin{array}{l}0.082(\mathrm{M}) \\
-0.038(\mathrm{G})\end{array}$ & -1 & 1 \\
\hline $\begin{array}{l}\text { NGAS_MODERATEa } \\
n=343(\mathrm{M}) \\
n=443(\mathrm{G})\end{array}$ & $\begin{array}{l}\text { Electricity provided by a natural gas-fired power plant } \\
\text { at a moderate distance from current residence. }\end{array}$ & $\begin{array}{l}-1=\text { near residence (reference case) } \\
1=\text { attribute level present } \\
0=\text { attribute level not present }\end{array}$ & $\begin{array}{l}0.041(\mathrm{M}) \\
0.011(\mathrm{G})\end{array}$ & -1 & 1 \\
\hline $\begin{array}{l}\text { NGAS_FAR } \\
n=343(\mathrm{M}) \\
n=443(\mathrm{G})\end{array}$ & $\begin{array}{l}\text { Electricity provided by a natural gas-fired power plant } \\
\text { at a distance far from current residence. }\end{array}$ & $\begin{array}{l}-1=\text { near residence (reference case) } \\
1=\text { attribute level present } \\
0=\text { attribute level not present }\end{array}$ & $\begin{array}{l}0.155(\mathrm{M}) \\
0.122(\mathrm{G})\end{array}$ & -1 & 1 \\
\hline $\begin{array}{l}\text { ASC_WIND }^{a} \\
n=927(\mathrm{M}) \\
n=1150(\mathrm{G})\end{array}$ & $\begin{array}{l}\text { Alternative specific constant for choosing Wind option } \\
\text { over Natural gas option }\end{array}$ & $\begin{array}{l}1=\text { wind choice } \\
0=\text { natural gas choice }\end{array}$ & $\begin{array}{l}0.630(\mathrm{M}) \\
0.615(\mathrm{G})\end{array}$ & 0 & 1 \\
\hline $\begin{array}{l}\text { FEES a } \\
n=927(\mathrm{M}) \\
n=1150(\mathrm{G})\end{array}$ & $\begin{array}{l}\text { Additional cost for choosing an option to be added to } \\
\text { current monthly electricity bill. (USD) }\end{array}$ & Continuous variable in dollars: $1 \$$ to $\$ 15$ & $\begin{array}{l}6.861(\mathrm{M}) \\
6.318(\mathrm{G})\end{array}$ & 1 & 15 \\
\hline $\begin{array}{l}\text { AVERAGE BILL b, } 1 \\
n=312(\mathrm{M}) \\
n=389(\mathrm{G})\end{array}$ & Average monthly electricity bill. & Continuous variable in dollars & $\begin{array}{l}111.680(\mathrm{M}) \\
132.084(\mathrm{G})\end{array}$ & $\begin{array}{l}15.5(\mathrm{M}) \\
45.5(\mathrm{G})\end{array}$ & 212.5 \\
\hline $\begin{array}{l}\text { SUPPORT_ARPSb } \\
n=312(\mathrm{M}) \\
n=389(\mathrm{G})\end{array}$ & Respondent support for the current RPS in WV. & $\begin{array}{l}1=\text { support, } \\
0=\text { neutral or do not support }\end{array}$ & $\begin{array}{l}0.430(\mathrm{M}) \\
0.329(\mathrm{G})\end{array}$ & 0 & 1 \\
\hline $\begin{array}{l}\text { SEECOAL_H } \\
n=312(\mathrm{M}) \\
n=389(\mathrm{G})\end{array}$ & $\begin{array}{l}\text { Respondent frequently or sometimes see a coal-fired } \\
\text { power plant from my residence. }\end{array}$ & $\begin{array}{l}1=\text { Frequently or sometimes } \\
0=\text { Never }\end{array}$ & $\begin{array}{l}0.487(\mathrm{M}) \\
0.620(\mathrm{G})\end{array}$ & 0 & 1 \\
\hline $\begin{array}{l}\text { SEEWIND_Hb } \\
n=312(\mathrm{M}) \\
n=389(\mathrm{G})\end{array}$ & $\begin{array}{l}\text { Respondent frequently or sometimes see a wind } \\
\text { turbine from my residence }\end{array}$ & $\begin{array}{l}1=\text { Frequently or sometimes } \\
0=\text { Never }\end{array}$ & $\begin{array}{l}0.240(\mathrm{M}) \\
0.717(\mathrm{G})\end{array}$ & 0 & 1 \\
\hline $\begin{array}{l}\text { CONCERN_BILLb } \\
n=312(\mathrm{M}) \\
n=389(\mathrm{G})\end{array}$ & $\begin{array}{l}\text { Respondent agreed to statement "for electricity } \\
\text { generation I am mainly concerned about how much I } \\
\text { will pay on my electricity bill". }\end{array}$ & $\begin{array}{l}\text { 1= strongly or somewhat agree } \\
0=\text { neutral, somewhat or strongly } \\
\text { disagree }\end{array}$ & $\begin{array}{l}0.740(\mathrm{M}) \\
0.874(\mathrm{G})\end{array}$ & 0 & 1 \\
\hline $\begin{array}{l}\text { INVEST_LESS } \\
\text { POLLUTION } \\
n=312(\mathrm{M}) \\
n=389(\mathrm{G})\end{array}$ & $\begin{array}{l}\text { Respondent agreed to statement "it's important to } \\
\text { invest in power plants that generate the least amount } \\
\text { of pollution". }\end{array}$ & $\begin{array}{l}1=\text { strongly or somewhat agree } \\
0=\text { neutral, somewhat or strongly } \\
\text { disagree }\end{array}$ & $\begin{array}{l}0.811(\mathrm{M}) \\
0.751(\mathrm{G})\end{array}$ & 0 & 1 \\
\hline $\begin{array}{l}\text { NEG ATTITUDE COAL } \\
n=312(\mathrm{M}) \\
n=389(\mathrm{G})\end{array}$ & $\begin{array}{l}\text { Negative attitude towards electricity generation } \\
\text { facilities that utilize coal as energy source. }\end{array}$ & $\begin{array}{l}1=\text { Very negative or somewhat negative } \\
0=\text { neutral, somewhat or very positive }\end{array}$ & $\begin{array}{l}0.295(\mathrm{M}) \\
0.136(\mathrm{G})\end{array}$ & 0 & 1 \\
\hline $\begin{array}{l}\text { NEG IMPACTS NGAS b } \\
n=312(\mathrm{M}) \\
n=389(\mathrm{G})\end{array}$ & $\begin{array}{l}\text { Given seven categories; the number of times natural } \\
\text { gas was selected as the electricity generation source } \\
\text { with the most negative impact. }\end{array}$ & Continuous variable in percentage & $\begin{array}{l}6.044(\mathrm{M}) \\
9.401(\mathrm{G})\end{array}$ & 0 & $\begin{array}{l}71.4(\mathrm{M}) \\
100.0(\mathrm{G})\end{array}$ \\
\hline $\begin{array}{l}\text { NEG IMPACTS WINDb } \\
n=312(\mathrm{M}) \\
n=389(\mathrm{G})\end{array}$ & $\begin{array}{l}\text { Given seven categories; the number of times wind } \\
\text { was selected as the electricity generation source with } \\
\text { the most negative impact. }\end{array}$ & Continuous variable in percentage & $\begin{array}{l}26.511(\mathrm{M}) \\
29.012(\mathrm{G})\end{array}$ & 0 & 100 \\
\hline $\begin{array}{l}\text { GENDER }^{\mathbf{b}} \\
n=312(\mathrm{M}) \\
n=389(\mathrm{G})\end{array}$ & Gender & $\begin{array}{l}1=\text { Female } \\
0=\text { male }\end{array}$ & $\begin{array}{l}0.490(\mathrm{M}) \\
0.465(\mathrm{G})\end{array}$ & 0 & 1 \\
\hline $\begin{array}{l}\text { AGE }^{\mathrm{b}} \\
n=312(\mathrm{M}) \\
n=389(\mathrm{G})\end{array}$ & Age & Years & $\begin{array}{l}64.846(\mathrm{M}) \\
61.512(\mathrm{G})\end{array}$ & $\begin{array}{l}27(\mathrm{M}) \\
23(\mathrm{G})\end{array}$ & $\begin{array}{l}98(\mathrm{M}) \\
96(\mathrm{G})\end{array}$ \\
\hline $\begin{array}{l}\text { ENV AFFILIATIONb } \\
n=312(\mathrm{M}) \\
n=389(\mathrm{G})\end{array}$ & Affiliation with any environmental organization. & $\begin{array}{l}1=\text { yes, } \\
0=\text { no }\end{array}$ & $\begin{array}{l}0.170(\mathrm{M}) \\
0.026(\mathrm{G})\end{array}$ & 0 & 1 \\
\hline $\begin{array}{l}4 \text { YEAR COLLEGE } \\
n=312(\mathrm{M}) \\
n=389(\mathrm{G})\end{array}$ & $\begin{array}{l}\text { Completed a } 4 \text { year college degree or Graduate } \\
\text { Degree }\end{array}$ & $\begin{array}{l}1=\text { least } 4 \text { year college } \\
0=\text { less than 4year college }\end{array}$ & $\begin{array}{l}0.603(\mathrm{M}) \\
0.267(\mathrm{G})\end{array}$ & 0 & 1 \\
\hline
\end{tabular}

${ }^{1}$ Missing average monthly electric bill values were replaced with the median of the population (Monongalia county; \$105.5 vs. Grant County; \$135.5).

${ }^{a}$ Choice observations summary statistics. Total observation (Monongalia County; N=927) and (Grant County; $\mathrm{N}=1150$ ).

b Unique respondents summary statistic. Total respondents (Monongalia County; N=312) and (Grant County; N=389).

(M) Monongalia County sampled population summary statistic and (G) Grant County sampled population summary statistic. 


\subsection{Model Results}

Table 6.4 presents results of the mixed logit model estimation of utility. The utility models were estimated using LIMDEP NLOGIT 4 statistical software. The mixed logit model of both counties are presented and discussed in this section. As discussed in previous sections, the mixed logit models are presented as the final utility models of choices made because of its ability to overcome the IIA assumption of the multinomial logit and its ability to incorporate preference heterogeneity within the sample population. The basic multinomial logit models of utility derived from choices made by respondents in each county is also presented in the appendix section as appendix III. It should be noted that the null hypothesis of equality between the basic multinomial logit model and the mixed logit model developed for the Grant County surveyed population could not be rejected at $95 \%$ confidence interval $\left(\chi^{2} 4=1.06 ; p\right.$ value $\left.=0.9006\right)$. In other words, the mixed logit model did not perform any better than the basic multinomial model. On the other hand, the mixed logit model of the Monongalia County sampled population statistically performed much better than its corresponding multinomial logit model $\left(\chi^{2}{ }_{4}=10.13\right.$; $\mathrm{p}$ value $\left.=0.0383\right)$.

A pooled mixed logit model of the sampled population from both counties was estimated (appendix IV) but the null hypothesis of equality between the two county models was rejected at $95 \%$ confidence interval $\left(\chi^{2} 23=66.25 ; \mathrm{p}\right.$ value $\left.=0.0001\right)$. As a result, a separate model was estimated for each county's sample population. The log likelihood and parameter estimates of all the models developed were stable and consistent at a 1,000 Halton intelligent draws. Observations included in each model to estimate utility were not weighted against the corresponding county population demographics. Only the computation of individuals' WTP for $10 \%$ electricity generated from renewable or alternative source and its attributes were weighted to account for discrepancies in age and education levels that existed between the sampled population and county population. As 
a result, interpretation of the mixed logit model results was only limited to the sample population.

The estimated WTP was interpreted as the mean WTP for the county population.

Table 6.4. Mixed Logit estimation of utility derived from consumers' choice between electricity generated from wind and natural gas.

\begin{tabular}{|c|c|c|}
\hline VARIABLE & $\begin{array}{l}\text { MONONGALIA } \\
\text { COUNTY SAMPLE }\end{array}$ & $\begin{array}{l}\text { GRANT COUNTY } \\
\text { SAMPLE }\end{array}$ \\
\hline \multicolumn{3}{|c|}{ RANDOM PARAMETERS (MEAN) } \\
\hline WIND_MODERATE & 0.262 & -0.149 \\
\hline WIND_FAR & $0.684 * *$ & $0.340 *$ \\
\hline NGAS_MODERATE & -0.324 & $-0.231^{*}$ \\
\hline NGAS_FAR & $1.152^{* * *}$ & $0.540 * *$ \\
\hline \multicolumn{3}{|c|}{ NON RANDOM PARAMETERS (MEAN) } \\
\hline ASC_WIND & $4.307^{* * *}$ & $1.660^{*}$ \\
\hline FEES & $-0.163 * * *$ & $-0.114 * *$ \\
\hline AVERAGE BILL & $-0.006^{*}$ & -0.001 \\
\hline SUPPORT_ARPS & $1.124 * *$ & 0.161 \\
\hline SEECOAL_H & -0.522 & -0.323 \\
\hline SEEWIND_H & 0.211 & -0.373 \\
\hline CONCERN_BILL & -0.525 & 0.128 \\
\hline INVEST_LESS POLLUTION & 0.579 & $0.641 * *$ \\
\hline NEG ATTITUDE COAL & $1.269 * *$ & $0.910 * *$ \\
\hline NEG IMPACTS NGAS & 0.015 & 0.005 \\
\hline NEG IMPACTS WIND & $-0.070 * * *$ & $-0.028 * *$ \\
\hline GENDER & 0.007 & 0.235 \\
\hline AGE & $-0.021 * *$ & -0.006 \\
\hline ENV AFFILIATION & 0.761 & $-1.308^{*}$ \\
\hline 4 YEAR COLLEGE & -0.102 & -0.304 \\
\hline \multicolumn{3}{|c|}{ STANDARD DEVATIONS OF RANDOM PARAMETER } \\
\hline WIND_MODERATE & 0.037 & 0.476 \\
\hline WIND_FAR & $2.373^{* * *}$ & 0.343 \\
\hline NGAS_MODERATE & 0.051 & 1.041 \\
\hline NGAS_FAR & $1.829 * *$ & 0.299 \\
\hline NUMBER OF OBSERVATIONS & 927 & 1150 \\
\hline LOG LIKELIHOOD & -425.86 & -626.71 \\
\hline MCFADDEN PSEUDO R-SQUARE & 0.34 & 0.21 \\
\hline
\end{tabular}

$* * * 1 \%$ significance, $* * 5 \%$ significance, $* 10 \%$ significance 


\subsection{Mixed logit Model Estimation}

The levels of proximity as an attribute of an electricity generation source were estimated in the mixed logit models as random parameters. All random parameters in the mixed logit model were assumed to be normally distributed. All other variables in the mixed logit model including additional monthly fees as an attribute were estimated as fixed parameters.

\subsection{Random Parameters Estimation}

Parameter estimates of locating wind turbines "far away" (0.68) and at "moderate" distances (0.26) from respondents residence were both positive in the Monongalia County model. Only the farthest distance parameter was statistically different from zero. Both proximity levels were estimated relative to the baseline of locating wind turbines at a location near the respondent's residence. Based on the signs of the parameter estimates, all things being equal, respondents in Monongalia County derived a positive utility from electricity generated from wind when the generation source (wind turbines) is located at the farthest location compared to the baseline location to the respondents' residence.

In the Grant County model, the moderate proximity parameter estimate was negative (-0.15) while the far away proximity parameter was positive $(0.34)$ for electricity generated from wind. Since the baseline parameter (near proximity level of locating wind turbines) was effect coded as negative one $(-1)$ rather than zero $(0)$, the baseline parameter can be interpreted as a negative summation of all $\mathrm{L}^{\text {th }}$ estimated parameters rather than zero (Bech \& Gyrd-Hansen, 2005). As a result, it can be inferred from the Grant County model that, the disutility that respondents derived from locating wind turbines at a moderate distance to their residence was much lesser compared to the disutility that was derived from the baseline proximity. Only the parameter estimate for the farthest proximity level attribute of wind turbines in the Grant County model was statistically 
significant. All things being equal, respondents in Grant County derived a positive utility from locating wind turbines at the farthest location away from their residence relative to the baseline location.

The parameter estimates for locating a natural gas-fired power plant at a moderate proximity level in the Monongalia County (-0.32) and Grant County (-0.23) models were both negative. Only the parameter estimate in the Grant County model was statistically significant. The negative and statistically significant parameter for locating a natural gas-fired power plant at a moderate location to a respondent's residence within the Grant County model implied that, all things being equal, the Grant County sampled population derived a negative utility from locating a natural gasfired power plant at the moderate proximity level from their residence. Since the baseline proximity level for a natural gas-fired power plant were effect coded as (-1) in both county's models, the disutility derived from locating a natural gas-fired power plant at the moderate proximity level in both counties can be assumed to be much less than the disutility that will be derived from the baseline proximity level. The parameter estimates of utility derived from siting a natural gas-fired power plant at a location that is far away from a respondent's residence in Monongalia County (1.15) and Grant County (0.54) were positive and statistically significant.

Within each county model, all other variables being held constant, the utility derived from siting a natural gas-fired power plant at a location that is far away from a respondent's residence was much higher than the utility derived from siting wind turbines at the farthest location relative to the baseline proximity level. Based on the magnitudes of parameter estimates of proximity in both county's models, it can also be inferred that respondents in Monongalia County derived a much higher utility as each of the two electricity generation sources are sited farther away from their residence compared to the sampled population in Grant County. The statistically significant 
and positive parameter estimate for the farthest location of each electricity generation source in both counties were not surprising. A vast number of literature on proximity as an attribute of renewable energy have found a similar results where consumers preferred the farthest siting location of wind turbines and derived a positive utility from the choice of such options (Krueger, Parsons, \& Firestone, 2011; Ladenburg \& Dubgaard, 2007). To the best of our knowledge, none of the studies reviewed for this research have explicitly sought the impact of proximity as an attribute of a natural gas-fired power plant on consumers preference for cleaner energy source.

\subsection{Derived Standard Deviations of Random Parameters}

The standard deviation of the random parameter estimate can be used to test the existence of preference heterogeneity in the sample population around the mean random parameter estimate. It captures the dispersion around the mean of the random parameter estimated over a number of random draws. A statistically significant standard deviation implies that some individuals within the sampled population have individual-specific parameter estimates that differ from the sampled population mean parameter estimate. On the other hand, if the dispersion around the mean is not statistically significant, then the mean parameter estimate represents the preference of the entire population (Hensher, Rose, \& Greene, 2005).

If the mean parameter estimated for the population and dispersion around the estimated mean are statistically significant, then the share of the population that are positively or negatively induced by the parameter of interested can be estimated (Train, 2009). Since the random parameters in both county's models were estimated with a normal distribution, the share of the population that derive a positive or negative inducement from a parameter estimate of an attribute level can be computed using a simple Wald statistic. 
Preference heterogeneity existed within the Monongalia County, but it only existed in the parameter estimates of locating each electricity generation source at the farthest proximity from respondent's residence (Table 6.4). Preference for locating wind turbines or a natural gas-fired power plant at a moderate proximity relative to the baseline proximity was homogenous within the Monongalia County sampled population. For the majority of the sampled population in the Monongalia County model, locating a wind farm or a natural gas-fired power plant at a farthest location away from an individual's residence relative to the baseline location was a positive factor on utility derived from the choice of wind or natural gas. The derived standard deviations of locating wind turbines (2.37) and a natural gas-fired power plant (1.83) at a proximity far away from the respondents residence were both statistically significant within the Monongalia County model (Table 6.4). This result meant that the preferences of a share of the sampled population differed from that of the sampled population mean for locating wind turbines or a natural gas-fired power plant at the farthest location away from a respondent's residence.

The dispersion around the mean parameter estimate of locating a wind turbine at a proximity far away from a respondent's residence within the Monongalia County model indicates that $61.4 \%$ of the sampled population derived a positive inducement from locating a wind turbine at the far proximity level whiles $38.6 \%$ of the sampled population derived a negative inducement from locating a wind turbine far from their residence. A higher share of the Monongalia County sampled population (73.6\%) perceived the siting of a natural gas-fired power plant at a location that is far away from their residence as a positive inducement to their utility and less than a third of the sampled population (26.4\%) derived a negative inducement from sitting a natural gas-fired power plant at a location that is far away from their residence. 
On the other hand, based on the statistically insignificant derived standard deviations of all random parameter estimates within the Grant County model, it can be inferred that the preference for proximity as an attribute for electricity generated from wind or a natural gas is homogenous within the sampled population. In other words, the mean random parameter estimates within the Grant County model captured all the sampled populations' preferences for proximity as an attribute of both electricity generation sources. Moreover as stated earlier in this section, statistically, the mixed logit model of utility derived from choices made by the sampled population in Grant County did not perform any better in than the basic multinomial logit model of the population.

\subsection{Non Random Parameters / Fixed Parameters}

Besides the parameter estimates of proximity and the choice label (wind or natural gas), which were estimated as alternative specific parameters, all other non-random parameters were estimated as generic parameters with homogenous degree of zero. Since the choice experiment used in this study was labeled, we assumed that all things being equal, the label conveyed some unobserved information or factors associated with each choice profile, and these factors will influence a particular choice among the two alternatives that a respondent makes. The labels can also be thought of as a source of unobserved utility derived from the choice presented (Hensher, Rose, \& Greene, 2005). Since only J-1 alternative specific constants can be estimated, an alternative specific constant of choosing electricity generated from wind relative to natural gas as energy sources was included in the model. All things being equal, this variable can be interpreted as the average role played by labeling each alternative in the utility model.

The unobserved utility derived by the sampled population in both Monongalia (4.31) and Grant (1.66) County models that can attributed to the alternative specific constant of choosing the wind option (ASC_wind) were positive and statistically significant. In other words, all things being equal, 
the choice of wind option over natural gas increased an individual's utility without any consideration to the attribute levels of proximity and additional cost. Based on the magnitudes of the estimated parameters, respondents in Monongalia County derived a much higher unobserved utility from the choice of electricity generated from wind compared to the unobserved utility derived from the wind option by the sampled population within the Grant County model.

Given the option to choose between generating $5 \%$ of the total electricity consumed in Norway from either wind, natural gas or hydroelectric sources relative to importing electricity generated with coal, Navrud and Braten (2007), also found that respondents derived a positive utility from the wind option and a negative utility from the natural gas option relative to the status quo option. On the other hand, Borchers et al. (2007), found that, respondents derived a negative utility from generating $10 \%$ of their electricity from either wind or farm methane. The magnitude of the disutility derived from the farm methane option was much higher than the wind option.

The differences in the level of utility derived from wind as an energy source between the sampled population in Monongalia County and Grant County can perhaps be attributed to respondents' prior experience with an existing wind farm. The majority of the sampled population in Grant County (70.0\%) indicated that they see wind turbines from their residence on a daily basis compared to only $24.0 \%$ of the sampled population in Monongalia County. Navrud and Braten (2007), found a similar trend in preferences and utility derived from a choice of wind by a population in a rural area with an existing wind farm compared to a population in a city with no wind turbines present. These authors attributed such a disparity in utility derived from a wind between two distinct locations to city dwellers unfamiliar with the disamenities associated with wind turbines. As a result, urban residents derived a much higher utility from electricity generated from wind compared to the rural dwellers with daily experience with an existing wind farm. 
All things being equal, respondents' daily experience with the disamenities associated with wind turbines may reduce the utility they derive from a choice of wind as the source of electricity generation. On the other hand, a sampled population from a location with no existing wind farms may derive a much higher utility from the choice of wind as the source of electricity generation. All things being equal, the sampled population in Monongalia County with limited (if any) daily experience with existing wind turbine within the county limits derived a much higher utility from the choice of electricity generated from wind over natural gas compared to the population in Grant County.

The additional premium that will be added to the current monthly electricity bill (fees) of respondents for a choice of $10 \%$ of electricity generated from wind or natural gas has negative and statistically significant parameter in both Monongalia (-0.16) and Grant (-0.11) County models. All else being equal, utility decreased in both county's models as additional cost to monthly electricity bill increased for a choice of $10 \%$ electricity generated from wind or natural gas. From an economic perspective, negative and statistically significant parameter estimates of additional cost per month were expected. A number of studies that have sought consumers' preference and WTP for renewable electricity have also found additional fees or cost to negatively impact the utility derived from the choice of wind as an electricity generation source (Bochner, 2014; Borchers, Duke, \& Parsons, 2007; Krueger, Parsons, \& Firestone, 2011; Ladenburg \& Dubgaard, 2007; Navrud \& Braten, 2007; Popkin, et al., 2013).

Also, the average electricity bill per month (average bill) had a negative, statistically significant parameter $(-0.006)$ in only the Monongalia County model. This meant that, as the average electricity bill of the sampled population in Monongalia County increased, the utility derived from a choice of $10 \%$ of electricity generated from wind relative to natural gas decreased. In a study of 
consumer's preference for green programs, Borchers et al. (2007), found no statistical significant impact of consumer's current electric bill on preference for green programs.

Within the Monongalia County model, the parameter estimate for support for the West Virginia renewable and alternative portfolio standard 2009 (support_ARPS) was positive (1.12) and statistically significant. All things being equal, respondents who supported the ARPS derived a positive utility from the choice of $10 \%$ of their electricity being generated from wind compared to natural gas. The parameter estimate of support for the ARPS policy was not statistically significant in the Grant County model.

The percentage number of times wind and natural gas were selected among the seven categories were used as variables to explain its impact on utility derived from the choice individuals made. The percentage number of times that natural gas was selected as the energy source with the most negative impact (neg impacts ngas) on all categories given was positive but not statistically significant in both counties models. The parameter estimate for the percentage number of times that wind energy was selected as the energy source with the most negative impact (neg impacts wind) was negative and statistically significant in the Monongalia (-0.07) and Grant County (-0.03) models. All things being equal, as the number of times wind was selected as the energy source with the most negative impact within a category increased, the utility derived from the choice of wind in both county's models decreased. This result was not surprising since from a Random Utility Theory perspective, a favorable attribute of a choice profile invariably drives the utility derived from making that choice out of a choice set. As a result, there seems to be a linear relationship between the percentage of times wind was chosen as source of electricity generation with the most negative impacts (given seven categories) and a decline in individuals' utility from the choice of wind option. 
Respondents were also asked about their general attitudes towards electricity generation facilities that utilize coal as an energy source. A parameter was estimated as a respondent's negative attitudes towards facilities that utilize coal (neg attitude coal), and it entered the utility models as a generic parameter for each choice. This parameter was positive and statistically different from zero in both models, Monongalia (1.27) and Grant (0.91). From an economic perspective, these results were expected since preferences for attributes and attitudes invariably drives utility. All else being equal, individuals who expressed a negative attitude toward a coalfired power plant derived positive utility from the wind option relative to the natural gas option.

In assessing the impact of respondents' attitudes and preferences on the utility derived from choice options given, respondents were asked to indicate their level of agreement to a series of statements about pollution, cost of electricity, and the need to invest in renewable electricity in question \#13. The parameter for respondent level of agreement to the statement, "it is important to invest in less polluting electricity generations source" (invest_less pollution) was positive in both county models, but only statistically significant in Grant County (0.64). All other variables held constant, the sampled population in Grant County who agreed that it was important to invest in less polluting electricity generation sources derived a positive utility from the wind option. Borchers et al. (2007), also found a similar results, where respondents who expressed concerns for the environmental impacts of electricity generation were more likely to choose a green program option over the status quo option of no green program. The parameters for the variable captured respondents concern about their electric bill when it comes to electricity supplied to them (concern_bill) were not statistically different from zero in either county model.

Socio-demographic parameters including age, gender, environmental group affiliation and highest level of education attained entered the models as generic parameters. The parameter 
estimate for attaining at least a 4-year college education or higher (4-year college) were negative in both county models but not statistically significant. Even though the education level variable was not statistically significant in both models, the negative sign of the parameter was not surprising. Ek (2005), found that individuals with higher education attainment than the average respondent are less likely to have a positive attitude towards wind. Krueger et al.(2011) found that education level to some degree is negatively correlated with utility derived from a choice of wind relative to coal in a sub-sample (bay area residents) of the total population surveyed in Delaware. Other studies have also found education does not statistically impact the utility derived from a choice of wind option (Ladenburg \& Dubgaard, 2007).

The parameter estimate of age was negative in both counties models but only statistically significant in the Monongalia County (-0.02) model. All things being equal, as a respondent's age increased within the sampled population in Monongalia County, utility derived from the choice of $10 \%$ electricity generated from wind decreased. Even though the findings on how age as a factor influence utility derived from green programs has been mixed, Krueger et al. (2011), found similar results in a sub-strata of the total sampled population in Delaware. The study found that disutility derived from the choice of wind option relative to fossil fuel within the inland sub-sampled population increases as the age of the respondent increases. On the other hand, Borchers, et al.,(2007) also found that respondents over 50 years and under 30 years of age both are more likely to choose a green program over the status quo of fossil fuels.

The parameter estimate for environmental affiliation (env affiliation) was negative (-1.31) and statistically significant only within the Grant County model. All things being equal, individuals that belong to an environmental protection or pro-environmental affiliated group derived a negative utility from choosing the wind option. This result was not surprising. Some of the prominent 
environmental affiliation groups in the state including the West Virginia Highlands Conservancy oppose all large, utility scale wind projects unless it is designed to replace equal amount of electricity that would have otherwise been generated from coal (West Virginia Highlands Voice, 2008). Further investigation into the respondents who indicated that they belonged to a proenvironment group revealed that approximately 50\% of the environmentally affiliated respondents perceived that wind turbines most negatively affect the view of landscape and wildlife compared to only $8 \%$ in both categories for natural gas-fired power plant gas. Moreover, $36 \%$ of those with environmental affiliation within the Grant County model perceived that wind turbines are the energy source that most negatively impact property value compared to only $9 \%$ for a natural gasfired power plants.

Based on choices made in the choice experiment section among this group (respondents with environmental group affiliation), the natural gas option was chosen $53 \%$ of the time compared to $47 \%$ for the wind option. This was based on thirty (30) choice situations that were included in the final utility model. In addition, the comments provided by individuals within this group seem to be overwhelmingly addressed towards the negative impacts of wind turbines on wildlife, landscape impacts and jobs. Some of the comments include: (1) "if you can figure out how to keep birds and bats from being killed that would help"; (2) "greater effort should be put into solving problems of noise pollution and wildlife death by turbines"..... "Energy use conservation should be encouraged"; (3) “......Wind turbines are an eyesore and take up too much landscape to be seriously considered as a large scale source of electricity..." and (4) "We cannot do away with coal. That will mean increase in property tax. Also it will affect a lot of families on the employment side".

Other variables included in the utility model such as individuals' negative attitude towards a natural gas-fired electricity generation source "neg impacts ngas", frequent sighting of a coal-fired 
generation source "seecoal_ $h$ " and frequent sighting of wind turbines "seewind_ $h$ " from respondents' residence were not statistically significant in both county models.

\subsection{Willingness to Pay Estimations}

From an economics perspective, the most common objective of utility derivation from a choice among options (discrete choice models) is to interpret it in some form of monetary measure that an individual is willing to give up to attain attributes (benefits) described in the choice made or "specific task" the respondent undertook (Hensher, Rose, \& Greene, 2005). Typically, economists measure welfare gains and losses (economic surplus) that are associated with each alternative combination of attributes relative to a status quo alternative. Economic surplus measures can either be a compensating surplus or an equivalent surplus. Compensating surplus is defined as the amount of money that is given or taken away from a person that makes him/her as well off as they were before a change. Equivalent surplus, on the other hand, is the amount of money that is given or take away, that makes a person well off as they would be after a change compared to the status quo situation (Bennett \& Adamowicz, 2001).

When linearity in utility model is assumed, part worth or implicit price is another useful measure of monetary value a person places on a non-market good. It measures the substitution rate or trade off rate between two attributes. The inclusion of a monetary attribute of alternatives allows for a measure of WTP for a non-market attribute. Since this study was based on a forced choice decision making, no status quo option was included in the choice sets presented to respondents. As a result, only the rate of substitution between monetary parameter estimate and non-market attributes of renewable and alternative electricity generation sources will be presented in this section. 
Detailed formulation of WTP for random and non-random parameters have been addressed in the theory section (chapter 3). Following an extension of Hensher et al. (2005) formulation of WTP for a non-market attribute estimated as random parameter with a normal distribution was estimated using equation (3.17) restated below:

$$
W T P_{n}=-\left(\frac{\left(\beta X_{i}+S D X_{i}^{*} \text { RDraws }\right)-\left(\beta X_{o}\right)}{\beta m o n e t a r y a t t r i b u t e}\right)
$$

Where $\left(W T P_{n}\right)$ represents each observation's estimated WTP to locate an electricity generation source from the baseline proximity level $\left(\beta X_{0}\right)$ to either the far proximity or moderate proximity levels $\left(\beta X_{i}\right)$. Each observation's random parameter estimate (coefficient of the proximity attribute) in the WTP formulation is drawn from a normal distribution. The estimation of each observation's WTP for proximity as an attribute of electricity generation accounts for the random parameter distribution through a multiplicative effect of a random draw (Rdraws) from the specified distribution and the point estimate of the standard deviation (SDXi) for the random parameter. The mean parameter estimate of the cost attribute (additional fee per month) is fixed (Bmonetaryattribute).

The WTP to locate an electricity generation source from the baseline to a moderate or far location for each observation was estimated using equation (3.17), and the mean WTP for each attribute for the surveyed population was computed over all observations. The results are presented in Table 6.5. The estimated WTP value for proximity as an attribute is interpreted relative to the baseline proximity level, which is coded as negative one (-1). As a result, the baseline parameter of near proximity level $\left(\beta X_{0}\right)$ in the WTP formulation takes a value of $(-1)$. A positive WTP will be interpreted as, all things being equal, the amount of money an individual is willing to 
give up in order to locate a facility at a proximity level presented to them relative the baseline proximity level.

Since the parameter estimate of the energy source chosen (wind or natural gas) was estimated as a fixed parameter in the mixed logit model, the WTP for wind as an energy source relative to natural gas was estimated with an implicit price formulation (equation 6.1) following Hensher, et al., (2005).

$$
\text { implicitprice }(z)=-\left(\frac{\beta \text { non-marketattribute }}{\beta \text { monetaryattribute }}\right)=-\left(\frac{\beta_{Z(\text { nonmarketatribute })}}{\mu}\right)
$$

The coefficient of the fixed non-market attribute parameter is represented as $\beta z$, and the parameter estimate of cost presented as $\mu$. The alternative specific constant associated with some level of unobserved utility derived from the label in the mixed logit models for each county was assumed to be fixed. All things held equal, an individual's WTP for electricity generated from wind relative to natural gas without any consideration to attributes presented was derived using the implicit function formulation in equation (6.1).

The mean WTP for the unweighted sampled population and the weighted sample population are both presented in this section. Also, two types of aggregation (adjusted and unadjusted) of mean WTP for each attribute over the total households of each county will be presented in this section. Details of how the aggregation over total household was computed can be found in section 3.4 of this study. As discussed in section 5.1, highly educated respondents and the elderly were over represented in both county's sampled population. Weighting of WTP was based on these two over represented variables. The weighting method used was a simple ratio of expected and actual percentages of education and age categories based on census data. The mean WTP to locate wind 
turbines or a natural gas-fired power plant at moderate and far away locations from the baseline location, all relative to the respondent's residence were computed using equation (3.17).

\subsubsection{Willingness to Pay for Proximity: Wind Turbine and Natural Gas-fired Power Plants}

Table 6.5 presents the mean WTP per month to locate wind turbines or a natural gas-fired power plant at moderate and far away proximity locations relative to the baseline of near the respondent's residence. Most of the discussions in this section will focus on the weighted mean WTP for each county. The weighted WTP for attributes account for the demographic disparities (age and education level) between the sampled population and target population of each county. All mean WTP per month presented in Table 6.5 for both county models were statistically different from zero at $95 \%$ confidence interval.

As depicted in Table 6.5, the weighted mean WTP per month to locate a wind turbine at a new location that is farther away from the respondent's residence compared to the baseline proximity was positive for the sampled populations of both counties and increased as the location of the facility was moved farther away from the baseline location. The mean WTP to locate wind turbines at moderate proximity rather than near an individual's residence within the Monongalia County (\$7.74) and Grant County (\$7.39) sampled populations were not statistically different from each other. This means that, on average there was a positive gain in welfare within both counties sampled population as a result of reducing disamenities derived based on locating wind turbines at a moderate proximity level rather than the baseline location of near an individual's residence. 
Table 6.5. Unweighted and weighted mean WTP for proximity to wind and natural gas as energy sources in electricity generation.

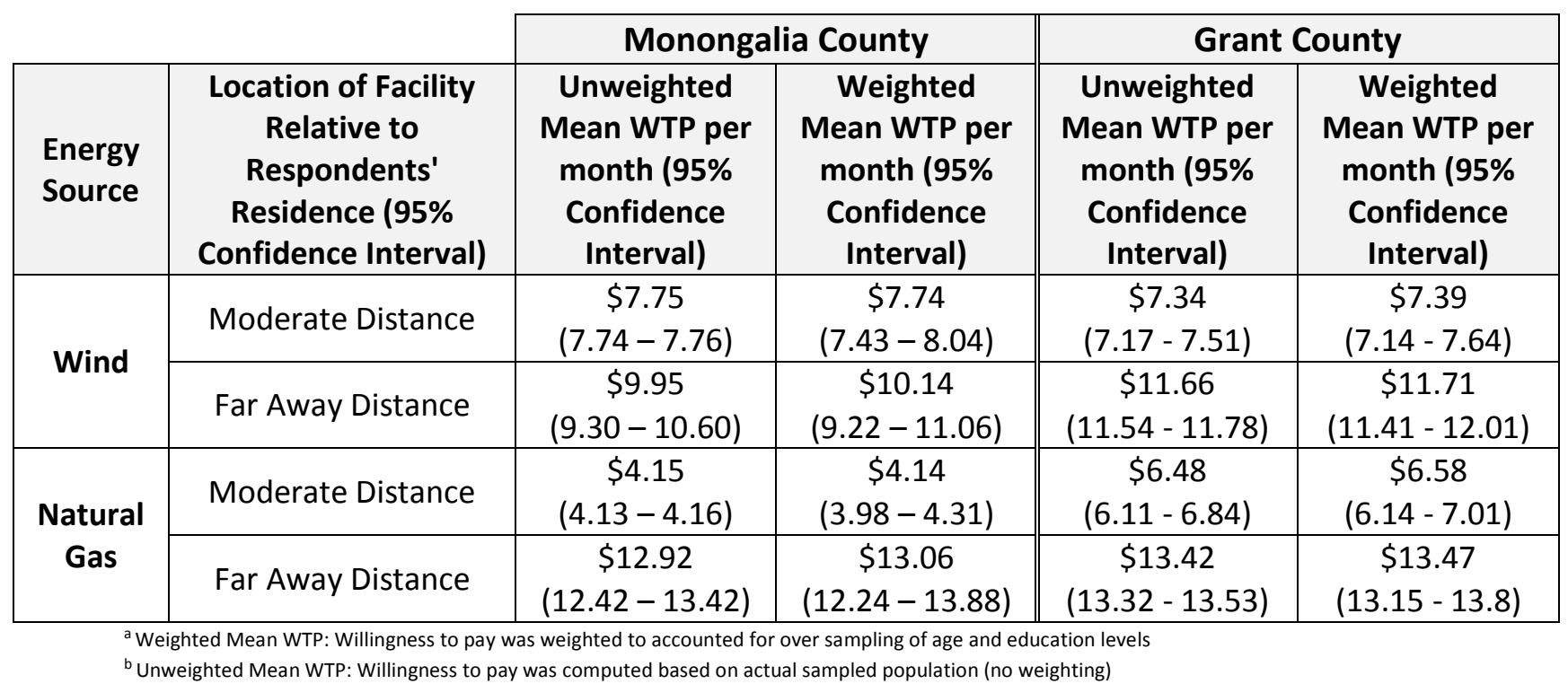

The gains in social benefit derived from locating wind turbines at the farthest location was significantly higher than the respective gains in social benefit that is derived from locating wind turbines at the moderate location relative to the baseline location in both counties. Based on weighted averages in Table 6.5, the Grant County population was willing to pay a higher premium per month $(\$ 11.71)$ compared to the Monongalia County population $(\$ 10.14)$ to locate wind turbines at a location that is "too far" to see relative to the baseline location. These weighted averages were statistically different from one another based on non-overlapping confidence intervals. This difference implied that the Grant County population valued the farthest location attribute of wind turbines from their residence more than the Monongalia County sampled population.

Such differences in WTP for the farthest proximity level relative to the baseline proximity level of a wind turbine perhaps can be attributed to the fact that a majority of the sampled population in Grant County (60\%) already see wind turbines on a daily basis from their residence compared to 
only (20\%) of the sampled population in Monongalia county. In other words, the majority of the population in Grant County are more familiar with the visual disamenities associated with wind turbines and perceive the gains in welfare to locating the wind turbines where they are too far to see relative to the baseline to be higher that population in Monongalia County. Ladenburg and Dubgaard (2007) also found that their sampled population who see wind turbines or have a summer home near the beach where wind turbines already existed offshore had a much higher WTP to locate wind turbines farther offshore compared to those who do not see wind turbines.

Ladenburg \& Dubgaard (2007) found that individual's WTP for the absence of disamenity is positively correlated with household income level. Our study did not directly assess the impact of a household's income on WTP for $10 \%$ of electricity generated from wind relative to natural gas or the location attributes. However, on average disparity in income existed between the sampled populations of the two counties. The median income level of the sampled population in Monongalia County was much higher $(\$ 62,500)$ than the Grant County sampled population $(42,500)^{5}$. Comparing the mean WTP estimates for the location attributes that were statistically different between the two counties (wind at a "far away" location and natural gas at a moderate location), it can be asserted that there was negative relationship between the median income level of a county's population and the mean WTP for the absence of disamenity.

The effect of education on consumers' preferences for green programs and WTP for absence of disamenities associated with wind turbines has been ambiguous. Even though Ladenburg and Dubgaard (2007) found that education did not significantly influence an individual's choice of proximity to wind turbines, the study showed that, all things being equal, highly educated individuals derived a much higher utility at any proximity level assessed than individuals with

\footnotetext{
${ }^{5}$ Median income levels were computed as the midpoint of the median categorical income bracket.
} 
lower education level. In other words, highly educated individuals appreciated the reduction in disamenities derived as a result of locating wind turbines farther away from them compared to individuals with lower education level. In this study, the percentage of the sampled population in Monongalia County with at least a four year college education (56.0\%) was twice as much as those within the Grant County sampled population (26.0\%).

The weighed mean WTP to locate a natural gas-fired power plant for the ARPS requirement at moderate and far proximity levels relative to the baseline proximity level of "near" an individual's current residence are presented in Table 6.5. On average, the sampled populations in both counties were willing to pay positive premiums per month to their electric bill to locate a natural gas-fired power plant at moderate and far proximity levels rather than the baseline. The weighted mean WTP per month to locate a natural gas-fired power plant increased with distance from an individual's current residence.

Both the weighted and unweighted averages were statistically larger for Grant County than for Monongalia County (Table 6.5). On average, the population in Grant County was willing to pay $58.9 \%$ more in premiums per month than the Monongalia County population to locate a natural gas-fired power plant at a moderate proximity level away from their residence. Clearly, the sampled population in Grant County valued the reduced disamenities derived from locating a natural gas-fired power plant further away more than the sampled population in Monongalia County.

On average, both sampled populations were willing to pay higher premiums per month to locate a natural gas-fired power plant at the farthest proximity level compared to the WTP for the moderate proximity level. It can be inferred from Table 6.5 that there are clear preferences within both counties sampled populations for a natural gas-fired power plant to be sited at a location that 
is "too far to see" from a respondent's current residence compared to the moderate proximity location. On average, the monetary value that the respondents placed on locating a natural gasfired power plant to the farthest proximity level was slightly higher within the Grant County (\$13.47) population compared to the Monongalia County $(\$ 13.06)$ population.

Based on the overlapping confidence intervals of the weighted mean WTP per month for the farthest proximity level of a natural gas-fired power plant in both counties, it can be asserted that consumers' WTP per month for a reduced disamenity derived from locating a natural gas-fired power plant to the farthest proximity level in both county's sampled population were not statistically different from each other. As a result, both populations have similar preferences for reduced disamenities that may be derived from locating a natural gas-fired power plant at a location that is too far to see from their current residence compared to a location near an individuals' current residence.

Based on the hypothesis that consumers' WTP to reduce a disamenity is positively correlated with prior experience with such a disamenity, there were no prior expectation on which sample population will place a higher premium on reduced disamenities from a natural gas-fired power plant. Neither county had an existing natural gas-fired power plant. The closest resemblance to a natural gas-fired power plant that existed within both counties are coal-fired power plants. In order to explain the potential impacts of a natural gas-fired power plant, respondents were referred to an appendix in the survey that described the impacts of a natural gas-fired power plant relative to a coal-fired power plant and wind turbines.

Based on a literature review, no study exists on consumers' WTP for proximity as an attribute of electricity generated from a natural gas-fired facility. The only closely related study on consumers' WTP for electricity generated from natural gas assessed consumers' WTP for proximity 
as an attribute of the natural gas drilling site. In assessing consumers' WTP for proximity as an attribute of electricity generated from hydraulically fractured natural gas, Popkin et al. (2013), found that individuals who lived within a shale drilling county required more compensation to generate electricity supplied to them from natural gas at any proximity level to the drilling site compared to those who lived in counties without shale drilling. It should be noted this study computed compensating variation as WTP for proximity.

Based on the findings of Popkin et al. (2013), oil and natural gas related drilling activities within Monongalia County and Grant County were assessed. Both counties are within the Marcellus shale gas basin. According to the West Virginia Geological and Economic Survey, as of March 2015, Monongalia County had 4,224 wells with owners and completion records (includes cancelled and reassigned permits) compared to only 35 wells in Grant County within the same category. Monongalia County has 705 wells with production records (includes cancelled and reassigned permits) compared to only 24 in Grant County within the same period (West Virginia Geological and Economic Survey, 2015).

Based on the data presented above, it would be logical to speculate that a higher number of residents in Monongalia County are more likely to feel the impacts of natural gas drilling (truck traffic, landscape change etc.) compared to residents in Grant County. As a result, the sampled population in Monongalia County may be expected to have a much higher WTP to locate a natural gas-fired power plant farther away from their current residence compared to the sampled population in Grant County. Yet, the opposite of this result was found when comparing the statistically larger mean WTP per month in Grant County at a moderate proximity attribute level for a natural gas-fired power plant (Table 6.5). The weighted mean WTP per month for the farthest proximity level relative to the baseline of a natural gas-fired power plant for the two counties was 
not statistically different from each other. Perhaps, prior experience with natural gas drilling does not significantly influence consumers' WTP for proximity as an attribute of a natural gas-fired power plant within the sampled populations examined in this study.

\subsubsection{Willingness to pay for Electricity Generated from Wind vs. Natural Gas}

The mean WTP for $10 \%$ of electricity generated from wind relative to a natural gas was estimated using a ratio of the parameter estimate of the alternative specific constant for choosing wind and the parameter estimate of additional monthly fee. The results are presented in Table 6.6.

Table 6.6. Mean WTP per month for wind as a renewable electricity generation source relative to natural gas as an alternative electricity generation source.

\begin{tabular}{|c|c||c|c|}
\hline \multicolumn{2}{|c||}{$\begin{array}{c}\text { Monongalia County } \\
\text { (95\% Confidence Interval) }\end{array}$} & \multicolumn{2}{c|}{$\begin{array}{c}\text { Grant County } \\
\text { (95\% Confidence Interval) }\end{array}$} \\
\hline $\begin{array}{c}\text { Unweighted Mean } \\
\text { WTP }^{\mathbf{a}}\end{array}$ & $\begin{array}{c}\text { Weighted Mean } \\
\text { WTP }^{\mathbf{b}}\end{array}$ & $\begin{array}{c}\text { Unweighted Mean } \\
\text { WTP }^{\mathbf{a}}\end{array}$ & $\begin{array}{c}\text { Weighted Mean } \\
\text { WTP }^{\mathbf{b}}\end{array}$ \\
\hline$\$ 26.48$ & $\$ 21.59$ & $\$ 14.54$ & $\$ 9.87$ \\
$(12.18-40.78)$ & $(9.93-33.25)$ & $(4.42-24.67)$ & $(3.01-16.73)$ \\
\hline
\end{tabular}

a Unweighted Mean WTP: Willingness to pay was computed based on actual sampled population (no weighting)

${ }^{b}$ Weighted Mean WTP: Willingness to pay was weighted to accounted for over sampling of age and education levels

As presented in Table 6.6 above, all things being equal, the sampled population in both counties preferred electricity generated from wind over natural gas. The weighted mean WTP per month for $10 \%$ of electricity supplied from wind as an energy source relative to natural gas was higher in the Monongalia County population (\$21.59) compared to Grant County (\$9.87). The Grant County weighted mean was 54.3\% lower than that of the Monongalia County population. Even though the disparity in the weighted mean WTP for $10 \%$ of electricity generated from wind relative to natural gas between the two counties was expected, the enormous disparity between the two weighted means was surprising. However, based on the overlapping confidence intervals, the 
weighted mean WTP for wind relative to natural gas electricity for the two county populations were not statistically different from each other.

Navrud and Braten (2007) attributed such differences in WTP for electricity from wind between a population sampled at a location with an existing wind turbine facility and a population sampled at a location with no wind turbine facility to the "not in my back yard effect" or NIMBY. Even though wind turbine facilities are not present within Monongalia County, wind turbines are located on the ridges at the northern border of Monongalia County and the state of Pennsylvania. As a result, about $24 \%$ of the sampled population indicated that they sometimes or frequently see wind from their residence on a daily basis. Therefore, Monongalia County cannot be considered as a county free from a wind turbine facility and the disamenities that may be associated with them.

Also, since the confidence interval of the weighted mean WTP for $10 \%$ of electricity generated from wind relative to natural gas for the two counties overlapped, a strict NIMBY effect cannot be claimed to exist between the two populations' preferences for electricity generated from wind over natural gas. If a NIMBY effect is present at all, it may be in some subtle form that is statistically unobserved. The unweighted mean WTP and the corresponding weighted mean WTP for electricity generated from wind relative to natural gas in both county's models were not different from each other based on the confidence interval overlaps. All mean WTP for electricity generated from wind relative to natural gas was statistically different from zero. 


\subsubsection{Willingness to Pay for Proximity: See vs. Do Not See Wind Turbines (Grant County)}

The hypothesis that the sub-sampled population who already see wind turbines from their residence place a much higher dollar value on the reduced disamenities derived from locating wind turbines from the baseline to a location that is too far to see was tested within the Grant County sampled population 6 . In order to assess the hypothesis that respondents who already see wind turbines from their residence have a higher mean WTP for the "far away" location than respondents that don't see them, the sampled population in Grant County was divided into two groups: (1) respondents who can see wind turbines from their residence, and (2) respondents who cannot see wind turbines from their residence.

Separate models were constructed for each group using the same variables that was utilized in the final model, except that "seewind_h" variable was excluded from the group models (appendix V). Table 6.7 presents the results of the unweighted and weighted mean WTPs for proximity an attribute for wind and natural gas energy sources for the two groups within the Grant County sampled population. The mean WTPs for electricity generated from wind relative to natural gas are presented in Table 6.7.

From Table 6.7, it is evident that respondents who had wind turbines within sight on a daily basis from their current residence have a much stronger preference for locating wind turbines at a location that is too far to see from their residence relative to a moderate proximity. The weighted mean WTP to locate wind turbines at the farthest proximity level $(\$ 8.27)$ was statistically greater

\footnotetext{
${ }^{6}$ Attempts to test this hypothesis were not successful within the Monongalia County sampled population. The mixed logit model that examined the sub-sample who do not have wind turbines within sight from their residence exhibited a flat log-likelihood. As a result, the mixed logit utility model of this sub-population within the total Monongalia County sampled population was discarded.
} 
than the weighted mean WTP for the moderate proximity level $(\$ 2.95)$ relative to the baseline proximity.

On the other hand, the group of respondents with no wind turbines within sight of their resident had a weighted mean WTP for a moderate proximity level $(\$ 5.14)$, which was not statistically different from the farthest proximity level $(\$ 5.76)$. As a result, there is no clear preference for either the moderate proximity level or farthest proximity level of wind turbines relative to the baseline proximity within the sampled population who do not have wind turbines within sight from their current residence.

Ladenburg and Dubgaard (2007) found that consumers' WTP for reduced visual disamenities from wind turbines among respondents who already can see wind turbines or have summer homes on the beach was higher to locate the facility farther offshore compared to the sampled population "who do not see" wind turbines. Results from Table 6.7 shows that this is true for only the farthest proximity level within the Grant County sampled population. The opposite trend is observed when the weighted mean WTP to locate wind turbines to the moderate proximity level relative to the baseline proximity for the two sub-populations in Grant County are compared.

Based on the results from Table 6.7, the monetary value placed on the benefits gained from locating wind turbines at a moderate proximity level was much lower $(\$ 2.95)$ for the group who have wind turbines within sight from their residence compared to those who do not have wind turbines within sight $(\$ 5.14)$ from their residence. Perhaps those respondents who have wind turbines within sight from their current residence perceived that the reduced disamenity derived from locating wind turbines to a moderate proximity level was not enough to merit a higher premium relative to the baseline. 
There was a clear preference for the farthest proximity relative to the baseline proximity for a natural gas-fired power plant in both sub-populations. Both sub-populations in Grant County placed a much higher premium on the reduced disamenities derived from moving a natural gasfired power plant to the farthest proximity level relative to the baseline proximity level. The weighted mean WTP to locate a natural gas-fired power plant at the farthest proximity level relative to the baseline proximity level for the two sub-populations in Grant County were not statistically different from each other. On the other hand, the sub-population with wind turbines within sight from their current residence were willing to pay a higher premium to locate a natural gas-fired power plant at the moderate proximity location relative to the baseline proximity location to compared to the sub-population who do not have turbines within sight from their current residence.

Table 6.7. Mean WTP for proximity as an attribute (Grant County sampled population only separated by wind turbine sighting).

\begin{tabular}{|c|c|c|c|c|c|}
\hline \multirow[b]{2}{*}{$\begin{array}{l}\text { Energy } \\
\text { Source }\end{array}$} & \multirow[b]{2}{*}{$\begin{array}{c}\text { Location of Facility } \\
\text { Relative to } \\
\text { Respondents' } \\
\text { Residence (95\% } \\
\text { Confidence Interval) }\end{array}$} & \multicolumn{2}{|c|}{ See Wind Turbines } & \multicolumn{2}{|c|}{ Do Not See Wind Turbines } \\
\hline & & $\begin{array}{l}\text { Unweighted } \\
\text { Mean WTP per } \\
\text { month (95\% } \\
\text { Confidence } \\
\text { Interval) }\end{array}$ & $\begin{array}{l}\text { Weighted } \\
\text { Mean WTP per } \\
\text { month (95\% } \\
\text { Confidence } \\
\text { Interval) }\end{array}$ & $\begin{array}{l}\text { Unweighted } \\
\text { Mean WTP per } \\
\text { month (95\% } \\
\text { Confidence } \\
\text { Interval) }\end{array}$ & $\begin{array}{l}\text { Weighted } \\
\text { Mean WTP per } \\
\text { month (95\% } \\
\text { Confidence } \\
\text { Interval) }\end{array}$ \\
\hline \multirow{2}{*}{ Wind } & Moderate Distance & $\begin{array}{c}\$ 2.96 \\
(2.48-3.43)\end{array}$ & $\begin{array}{c}\$ 2.95 \\
(2.49-3.50)\end{array}$ & $\begin{array}{c}\$ 5.22 \\
(5.20-5.24)\end{array}$ & $\begin{array}{c}\$ 5.14 \\
(4.93-5.36)\end{array}$ \\
\hline & Far Away Distance & $\begin{array}{c}\$ 8.20 \\
(8.18-8.22)\end{array}$ & $\begin{array}{c}\$ 8.27 \\
(8.04-8.49)\end{array}$ & $\begin{array}{c}\$ 5.73 \\
(5.00-6.46)\end{array}$ & $\begin{array}{c}\$ 5.76 \\
(4.87-6.66)\end{array}$ \\
\hline \multirow{2}{*}{$\begin{array}{c}\text { Natural } \\
\text { Gas }\end{array}$} & Moderate Distance & $\begin{array}{c}\$ 3.27 \\
(2.63-3.91)\end{array}$ & $\begin{array}{c}\$ 3.26 \\
(2.53-3.99) \\
\end{array}$ & $\begin{array}{c}\$ 5.42 \\
(5.39-5.45) \\
\end{array}$ & $\begin{array}{c}\$ 5.34 \\
(5.11-5.57) \\
\end{array}$ \\
\hline & Far Away Distance & $\begin{array}{c}\$ 9.40 \\
(9.40-9.42)\end{array}$ & $\begin{array}{c}\$ 9.49 \\
(9.23-9.74)\end{array}$ & $\begin{array}{c}\$ 7.41 \\
(5.95-8.87)\end{array}$ & $\begin{array}{c}\$ 7.54 \\
(5.80-9.28) \\
\end{array}$ \\
\hline
\end{tabular}

${ }^{a}$ Weighted Mean WTP: Willingness to pay was weighted to accounted for over sampling of age and education levels

${ }^{\mathrm{b}}$ Unweighted Mean WTP: Willingness to pay was computed based on actual sampled population (no weighting) 
Table 6.8 presents the mean WTP per month results for $10 \%$ of electricity generated from wind relative to natural gas within the two groups in Grant County (see vs. do not see wind turbines from home). The weighted mean WTPs were not statistically different between the two groups based on overlapping confidence intervals. Moreover, the group with wind turbines within sight from their current residence had mean WTP (both unweighted and weighted) that were not statistically different from zero at $95 \%$ confidence interval. These means were statistically different from zero at $90 \%$ confidence interval.

Table 6.8. Mean WTP per month for wind as a renewable electricity generation source relative to natural gas (Grant County sampled population only separated by wind turbine sighting).

\begin{tabular}{|c|c|c|c|c|}
\cline { 2 - 5 } \multicolumn{1}{c|}{} & \multicolumn{2}{c|}{ See Wind Turbines } & \multicolumn{2}{c|}{ Do Not See Wind Turbines } \\
\hline \multirow{2}{*}{ Energy } & $\begin{array}{c}\text { Unweighted } \\
\text { Mean WTP per } \\
\text { month (95\% } \\
\text { Confidence } \\
\text { Interval) }\end{array}$ & $\begin{array}{c}\text { Weighted Mean } \\
\text { WTP per month } \\
\text { (95\% Confidence } \\
\text { Interval) }\end{array}$ & $\begin{array}{c}\text { Unweighted } \\
\text { Mean WTP per } \\
\text { month (95\% } \\
\text { Confidence } \\
\text { Interval) }\end{array}$ & $\begin{array}{c}\text { Weighted Mean } \\
\text { WTP per month } \\
\text { (95\% Confidence } \\
\text { Interval) }\end{array}$ \\
\hline Wind & $\begin{array}{c}\$ 9.24 \\
(-0.80-19.29)\end{array}$ & $\begin{array}{c}\$ 6.27 \\
(-0.55-13.09)\end{array}$ & $\begin{array}{c}\$ 25.48 \\
(2.04-48.92)\end{array}$ & $\begin{array}{c}\$ 17.29 \\
(1.38-33.20)\end{array}$ \\
\hline
\end{tabular}

a Weighted Mean WTP: Willingness to pay was weighted to accounted for over sampling of age and education levels

${ }^{\mathrm{b}}$ Unweighted Mean WTP: Willingness to pay was computed based on actual sampled population (no weighting).

\subsubsection{Aggregated WTP for Proximity \& Energy Source (Weighted Sampled Population)}

The mean weighted WTP to locate wind turbines or a natural gas-fired power plant at moderate or far proximity levels from their respective baseline proximity level were aggregated over the total households within each county. According to the U.S. Census Bureau, as of 2013, the total households in Monongalia County $(36,449)$ were about eight times the total households in Grant County $(4,449)$ (U.S. Census Bureau, 2013). In order to account for non-responses within the sampled population in each county, adjusted total households for each county were computed. The 
adjusted total households assumed that the mean WTP of non-respondent households was zero.

After accounting for a 73\% non-response rate in Monongalia County and a 64.7\% rate in Grant

County, the total households used to compute the adjusted annual aggregate WTP values in

Monongalia County and Grant County were 9,841 and 1,571 households, respectively.

Table 6.9 presents the results of the aggregate annual WTP to locate wind turbines or a natural gas-fired power plant at moderate and far proximity levels away from a respondent's current residence for both counties. The adjusted total households in both counties on aggregate were willing to pay a positive premium annually to locate wind turbines or a natural gas-fired power plant at the moderate and far proximity locations relative to the baseline proximity location.

Table 6.9. Aggregate annual WTP for moderate and far away proximity levels.

\begin{tabular}{|c|c|c|c|c|c|}
\hline & & \multicolumn{2}{|c|}{ Monongalia County } & \multicolumn{2}{|c|}{ Grant County } \\
\hline $\begin{array}{l}\text { Energy } \\
\text { Source }\end{array}$ & \begin{tabular}{|c|} 
Location of \\
Facility Relative \\
to Respondents' \\
Residence \\
\end{tabular} & $\begin{array}{l}\text { Total Households } \\
\text { (95\% Confidence } \\
\text { Interval) }\end{array}$ & \begin{tabular}{|c||} 
Adjusted Households a \\
(95\% Confidence \\
Interval)
\end{tabular} & $\begin{array}{l}\text { Total Households } \\
\text { (95\% Confidence } \\
\text { Interval) }\end{array}$ & $\begin{array}{c}\text { Adjusted Households a } \\
\text { (95\% Confidence } \\
\text { Interval) }\end{array}$ \\
\hline \multirow{2}{*}{ Wind } & $\begin{array}{l}\text { Moderate } \\
\text { Distance }\end{array}$ & $\begin{array}{c}\$ 3,385,383 \\
(3,249,793-3,516,600)\end{array}$ & $\begin{array}{c}\$ 914,053 \\
(877,444-949,482)\end{array}$ & $\begin{array}{c}\$ 394,537 \\
(381,190-407,884)\end{array}$ & $\begin{array}{c}\$ 139,272 \\
(134,560-143,983)\end{array}$ \\
\hline & $\begin{array}{l}\text { Far Away } \\
\text { Distance }\end{array}$ & $\begin{array}{c}\$ 4,435,114 \\
(4,032,717-4,837,511)\end{array}$ & $\begin{array}{c}\$ 1,197,481 \\
(1,088,834-1,306,128)\end{array}$ & $\begin{array}{c}\$ 625,173 \\
(609,157-641,190)\end{array}$ & $\begin{array}{c}\$ 220,686 \\
(215,032-226,340)\end{array}$ \\
\hline \multirow{2}{*}{$\begin{array}{l}\text { Natural } \\
\text { Gas }\end{array}$} & $\begin{array}{l}\text { Moderate } \\
\text { Distance }\end{array}$ & $\begin{array}{c}\$ 1,810,786 \\
(1,740,804-1,885,142)\end{array}$ & $\begin{array}{c}\$ 488,912 \\
(470,017-508,988)\end{array}$ & $\begin{array}{c}\$ 351,293 \\
(327,802-374,250)\end{array}$ & $\begin{array}{c}\$ 124,006 \\
(115,714-132,110)\end{array}$ \\
\hline & $\begin{array}{l}\text { Far Away } \\
\text { Distance }\end{array}$ & $\begin{array}{c}\$ 5,712,287 \\
(5,353,629-6,070,945)\end{array}$ & $\begin{array}{c}\$ 1,542,318 \\
(1,445,480-1,639,155)\end{array}$ & $\begin{array}{c}\$ 719,136 \\
(702,052-736,754)\end{array}$ & $\begin{array}{c}\$ 253,855 \\
(247,824-260,074)\end{array}$ \\
\hline \multicolumn{2}{|c|}{ Number of Households } & 36,449 & $9,841^{a}$ & 4,449 & $1,571^{a}$ \\
\hline
\end{tabular}


Within both county's households, the annual aggregate WTP for a reduction in disamenities derived from moving wind turbines from the baseline proximity to the farthest proximity level away from a household was higher compared to the corresponding annual aggregate WTP for the moderate proximity level. A similar trend was observed within both county's annual aggregate WTP for proximity as an attribute of natural gas-fired power plant. The adjusted households in both counties placed a much higher dollar value per year on the reduced disamenities derived from siting the facility at the farthest location compared to the moderate proximity location (all relative to the baseline proximity) of a natural gas-fired power plant.

In other words, within the adjusted total households of each county, all things being equal, the annual social benefits derived from the farthest proximity level of each electricity generation source were higher compared to the gains in welfare from the respective moderate proximity levels. From the "welfarism framework" of economics, all things being equal, the policy option that generates the highest social benefits or utility among possible alternatives may be the most likely option to adopt (Brouwer, Culyer, van Exel, \& Rutten, 2008; Hurley, 2014).

From Table 6.9, it can be deduced that the households in Monongalia County derived a higher social benefit per year from locating a natural gas-fired power plant at the farthest proximity level compared to the social benefits derived from wind turbines at the farthest proximity. A similar trend of high social benefits derived from the farthest proximity level of a natural gas-fired power plant compared to the respective social benefits derived from wind turbines at the farthest proximity level was observed within the adjusted total households in Grant County. On the other hand, when the moderate proximity levels of wind turbines and a natural gas-fired power plant are considered, the aggregate social benefits derived from locating wind turbines were higher in both 
counties than those benefits from locating a natural gas-fired power plant at the moderate proximity level relative its respective baseline proximity.

In order to assess the aggregate social benefits per year derived from a choice of $10 \%$ electricity generated from wind relative to natural gas, the mean WTP per respondent was aggregated over the total households of each county's population. Again, an adjusted total household annual WTP was computed for each county and the results are presented in Table 6.10. On aggregate, the adjusted total households in Monongalia County $(\$ 2,549,772)$ and Grant County $(\$ 186,042)$ were both willing to pay a positive premium annually for $10 \%$ of electricity supplied to them to be generated from wind relative to natural gas.

Even though the adjusted total households in Grant County were willing to pay a positive premium annually for $10 \%$ of electricity generated from wind relative to natural gas, the value was minimal compared to the adjusted Monongalia County households. The annual total social benefits derived from generating $10 \%$ of electricity supplied to consumers in Monongalia County from wind relative to natural gas was at least fourteen times higher than Grant County. The differences in aggregate social gains perhaps can be attributed to socio-demographic differences between the population of the two counties and to the fact that a majority of the sampled population in Grant County constantly see wind turbines from their current residence compared to relatively few residents of Monongalia County.

As a result of such familiarity with the disamenities from wind, it is possible that these households prefer less of this disamenity and are not willing to pay a higher premium for electricity generated from wind. Navrud and Braten (2007) examined two populations' WTP for green electricity in Denmark and found a similar results in the population that had wind turbines within the local area compared to the population with no such facility within the local area. 
Table 6.10. Aggregate annual WTP for wind energy relative to natural gas.

\begin{tabular}{|c|c|c||c|c|}
\cline { 2 - 5 } \multicolumn{1}{c|}{} & \multicolumn{2}{c||}{ Monongalia County } & \multicolumn{2}{c|}{ Grant County } \\
\hline $\begin{array}{c}\text { Energy } \\
\text { Source }\end{array}$ & $\begin{array}{c}\text { Total Households } \\
(95 \% \text { Confidence Interval) })\end{array}$ & $\begin{array}{c}\text { Adjusted Total } \\
\text { Households } \\
\text { (95\% Confidence Interval) }\end{array}$ & $\begin{array}{c}\text { Total Households } \\
\text { (95\% Confidence } \\
\text { Interval) }\end{array}$ & $\begin{array}{c}\text { Adjusted Total } \\
\text { Households } \\
\text { (95\% Confidence } \\
\text { Interval) }\end{array}$ \\
\hline Wind & $\begin{array}{c}\$ 9,443,601 \\
(\$ 4,343,263-\$ 14,543,151)\end{array}$ & $\begin{array}{c}\$ 2,549,772 \\
(\$ 1,172,681-\$ 3,926,651)\end{array}$ & $\begin{array}{c}\$ 527,030 \\
(\$ 160,698-\$ 893,181)\end{array}$ & $\begin{array}{c}\$ 186,042 \\
(\$ 56,726-\$ 315,293)\end{array}$ \\
\hline $\begin{array}{l}\text { Number of } \\
\text { Households }\end{array}$ & 36,449 & $9,841^{\text {a }}$ & 4,449 & $1,571^{\text {a }}$ \\
\hline
\end{tabular}

a Total households adjusted for non-responses using the response rate in the sampled population ( non-respondents and respondents who did not answer the survey were assumed to have zero mean willingness to pay for each attribute).

The total county population of the two counties surveyed in this study widely differed from each other (Monongalia County: 96,189 vs. Grant County: 11,937). The aggregate annual WTP for location attributes and energy were also computed on a per capita basis. The aggregate households annual WTP per capita for attribute levels were computed as a ratio of total households aggregated annual WTP (unadjusted for non-response rate) for each attribute level divided by the total population of each county. The results of the aggregate annual WTP per capita for the location attributes and energy source are presented in table 6.11 and 6.12 .

Aside from the parameters that represented households WTP for electricity generated from wind turbines located at a "far away" location and a natural gas-fired facility located at a moderate location relative to their residence, none of the computed annual WTP per capita were statistically different between the two counties. Even though the annual WTP per capita for $10 \%$ of electricity generated from wind relative to natural gas within the Monongalia County population was at least two times greater than the Grant County population (Monongalia County: $\$ 98.18$ vs. Grant County: \$44.15), they were not statistically different from each other. 
Table 6.11. Aggregate annual WTP per capita for moderate and far away proximity levels

\begin{tabular}{|c|c|c|c|}
\hline $\begin{array}{c}\text { Energy } \\
\text { Source }\end{array}$ & $\begin{array}{c}\text { Location of Facility } \\
\text { Relative to Respondents' } \\
\text { Residence }\end{array}$ & Monongalia County & Grant County \\
\hline \multirow{4}{*}{ Wind } & Moderate Distance & $\begin{array}{c}\$ 35.20 \\
(33.79-36.56)\end{array}$ & $\begin{array}{c}\$ 33.05 \\
(31.93-34.17)\end{array}$ \\
\cline { 2 - 4 } & Far Away Distance & $\begin{array}{c}\$ 46.11 \\
(41.92-50.29)\end{array}$ & $\begin{array}{c}\$ 52.37 \\
(51.03-53.71)\end{array}$ \\
\hline \multirow{3}{*}{$\begin{array}{c}\text { Natural } \\
\text { Gas }\end{array}$} & Moderate Distance & $\begin{array}{c}\$ 18.83 \\
(18.10-19.60)\end{array}$ & $\begin{array}{c}\$ 29.43 \\
(27.46-31.35)\end{array}$ \\
\cline { 2 - 4 } & Far Away Distance & $\$ 59.39$ & $\$ 60.24$ \\
$(55.66-63.11)$ & $(58.81-61.72)$ \\
\hline
\end{tabular}

Table 6.12. Aggregate annual WTP per capita for wind energy relative to natural gas

\begin{tabular}{|c|c||c|}
\cline { 2 - 3 } \multicolumn{1}{c|}{} & Monongalia County & Grant County \\
\hline \multirow{2}{*}{ Energy Source } & Per Capita & Per Capita \\
& (95\% Confidence Interval) & (95\% Confidence Interval) \\
\hline \multirow{2}{*}{ Wind } & $\$ 98.18$ & $\$ 44.15$ \\
& $(\$ 45.15-\$ 151.19)$ & $(\$ 13.46-\$ 74.82)$ \\
\hline \hline Total Population & 96,189 & 11,937 \\
\hline
\end{tabular}




\subsubsection{Test of Hypothetical Bias in Uncertain Choices (Overstating WTP)}

In assessing the possible hypothetical bias that may exist in the choice experiment

responses, respondents' certainty levels for choices made were assessed. Following an extension of the methodology used by Ready, Champ, \& Lawton (2010), choices made with certainty levels less than seven (7=fairly certain) were classified as an uncertain choice and have the potential to be biased. As a result, all choice situations with certainty levels less than seven were rejected from the analysis, and a mixed logit model for utility derived from a choice of electricity generated from wind or natural gas was re-estimated with only choice options that had a certainty response above six.

Statistically, it was important to verify if differences exist between the utility model derived with only choices made with certainty levels above six and those made with certainty levels below seven. In order to test for differences in utility models between the two sub-populations (based on certainty levels), a model that used only choice situations with certainty levels less than seven was also estimated for each county. A summary statistic of the certainty levels of the choices that respondents in each county made are presented in appendix VI. The majority of the sampled population in Monongalia County (74.9\%) and Grant County (68.5\%) were at least fairly certain to very certain about the choices that they made.

The mixed logit model estimation of at least one sub-population in each county (certain vs. uncertain choices) had an estimation difficulty related to either a flat log likelihood or having none of the parameter estimates in the model being statistically significant after a very high number of iteration attempts. As a result of the mixed logit estimation difficulties encountered, multinomial logit models were used to assess potential hypothetical bias that may exist in the data this study. Multinomial logit models of the two sub-populations within each county (certain and uncertain choices) were estimated and compared to a pooled model in each county. The multinomial logit 
models of utility estimated based on certainty levels of choices made for both counties are presented in appendix VII.

Using the log likelihood ratio test, the null hypothesis of equality between the two subpopulations models and the pooled model of each county's sampled population were rejected at $95 \%$ confidence interval in both Monongalia County $\left(\chi^{2}{ }_{19}=36.89 ; \mathrm{p}\right.$ value $\left.=0.0082\right)$ and Grant County $\left(\chi^{2}{ }_{19}=41.69 ; p\right.$ value $\left.=0.0020\right)$. In other words, within each county, the two subpopulations (certain and uncertain choices) were independent of each other and cannot be pooled together. As a result, the two sub-populations may have different WTP for attributes of interest assessed in this study (energy source and proximity). If differences in WTP for attributes of interest assessed in this study exist between the sub-populations in each county, then hypothetical bias exist in the data used in this study.

The WTP for attributes of interest of this study (energy source and proximity levels) were re-estimated for the two sub-populations in each county. All WTP estimations were derived using the delta method. The weighted mean WTP for $10 \%$ of the electricity generated from wind relative to natural gas for the two sub-populations were not statistically different from each other within each county. This assessment was based on the overlapping confidence intervals of the mean WTP estimates for the sub-populations of each county. Similarly, there were no statistical difference between the weighted mean WTP for each proximity level of an electricity generation facility assessed for the two sub-populations of each county.

The end result was that there was no statistical evidence that respondents who were uncertain about their choices overstated their WTP for all attributes of interest in this study. The results of the weighted mean WTP for $10 \%$ of electricity generated from wind (relative to natural 
gas and the proximity levels of each electricity generation source for the two sub-populations of each county are presented in appendix VIII. Even though the utility models of the sub-populations separated based on certainty levels in each county were statistically independent of each other, there was no evidence of hypothetical bias (overstating WTP) in the WTP estimates for attributes of interest assessed in this study between the two groups.

\subsubsection{An Assessment of Factors Influencing Respondents' Certainty Level}

An alternative explanation of respondent's certainty levels for choices made was explored in both county's sampled populations using a logistic model. Predictors of certainty levels in the logistic model included socio-demographic characteristics of respondents (income level, gender, age, education level and affiliation to pro-environment group), sighting of existing coal-fired facilities from their residence (SEECOAL_H), sighting of existing wind turbines from their residence (SEEWIND_H) and support for the ARPS policy (SUPPORT_ARPS). Table 6.13 below presents the results of the logistic models of respondents' certainty levels in both counties.

As observed in Table 6.13, the variables indicating support for the ARPS, gender, and age were statistically significant within the Monongalia County sampled population. Within the Grant County logistic model, gender, education level, sighting of coal-fired facility and wind turbine (from their residence) explained the certainty levels of respondents' choices. 
Table 6.13. A Logistic model of certainty level.

\begin{tabular}{|l|c|c||c|c|}
\hline \multicolumn{1}{|c|}{ VARIABLE } & \multicolumn{2}{c||}{ MONONGALIA COUNTY } & \multicolumn{2}{c|}{ GRANT COUNTY } \\
\hline \hline SUPPORT_ARPS & Coefficients & Odds Ratio & Coefficients & Odds Ratio \\
\hline SEECOAL_H & $0.815^{* * *}$ & 2.260 & 0.161 & 1.175 \\
\hline SEEWIND_H & 0.220 & 1.246 & $-0.400^{* *}$ & 0.670 \\
\hline GENDER & 0.034 & 1.034 & $0.343^{*}$ & 1.410 \\
\hline AGE & $-0.666^{* * *}$ & 0.514 & $-0.661^{* * *}$ & 0.515 \\
\hline ENV AFFILIATION & $0.023^{* * *}$ & 1.024 & -0.002 & 0.998 \\
\hline 4 YEAR COLLEGE & -0.313 & 0.732 & 0.495 & 1.641 \\
\hline CONSTANT & 0.134 & 1.143 & $0.308^{*}$ & 1.361 \\
\hline \hline NUMBER OF OBSERVATIONS & -0.441 & 0.644 & $0.990^{* * *}$ & 2.692 \\
\hline LOG LIKELIHOOD & 886 & 1075 & \\
\hline \hline Wald Chi ${ }^{2}$ & -459.62 & & -643.30 & \\
\hline \hline *** 1\% significance, ** 5\% significance, * & $\mathbf{7 6 . 1 0 * * *}$ significance & $\mathbf{3 9 . 2 2 * * *}$ \\
\hline
\end{tabular}

The odds of a respondent being certain of their choice relative to uncertain was computed for statistically significant parameters in each county's logistic model. The odds that a respondent who supported the ARPS policy within Monongalia County sampled population would be certain about their choice increased by a factor of 2.3 relative to those who did not support the ARPS policy. Support for the ARPS policy did not statistically impact certainty levels of the sampled population in Grant County. Female respondents in both counties were less likely to be certain about their choice compared to male respondents. For female respondents in both counties, the odds of being certain about choices made decreased by a factor of 0.51 compared to their male counter parts.

Respondent's age as a predictor of certainty level was only statistically significant within the Monongalia County sampled population. A one year increase in a respondents' age increase the odds of being certain about choices made by a factor of only 1.02. Other predictors of respondent's certainty level including frequent sighting of wind turbines "SEEWIND_H" or coal-fired facility 
"SEECOAL_H” from residence and education level “4 YEAR COLLEGE” were only statistically significant within the Grant County logistic model.

Respondents who had a coal-fired facility within view from their residence in Grant County were less likely to be certain about their choices relative to those who had no such facility within view from their residence. For the sampled population with a coal-fired facility within view from their residence, the odds of being certain about their choice decreased by a factor of 0.69 relative to those with no such facility within view from their residence. On the other hand for a respondent who had wind turbines within view from their residence, the odds of being certain about the choices made increased by a factor of 1.4 relative to those without wind turbines within view from residence.

In conclusion, the results of the logistic regression model of each county's population suggests that beside the demographic variable gender, different factors contributed to certainty levels of respondents in each county. Respondents' gender, age and support for the ARPS policy were the contributing factors of Monongalia county respondents' certainty levels. On the other hand, the variables; gender, education level, frequency of sighting wind turbines from residence and frequency of sighting a coal-fired facility from residence contributed to the certainty levels of the Grant County sampled population. 


\subsubsection{Test of Choice Order Effect on Utility Model (Position Order Effect)}

Even though choice sets were randomly blocked (12 blocked) and respondents were randomly assigned to a block (both online and paper survey), the order in which choice sets were presented in a block were not randomized for each respondent. Rather, respondents were instructed to answer each choice set independent of the other. An excerpt from the instruction that was given to respondents in the choice experiment section of the survey said "...It is important for you to answer questions 14, 15, and 16 independent of one another. For example, please do not let the options presented to you in question 14, influence your choice in questions 15 and 16. For each question, choose the option (Wind Power or Natural Gas Power) that best reflects your preferences". This part of the instruction was in bold letters to convey its importance to the respondents.

Since this survey was not a face-to-face interview, not randomizing the order of how choice sets were presented to respondents may still present potential order impact where a particular option especially in the first choice set for a particular block was chosen by the majority of the sampled population. As an example, if the wind option was chosen in choice set one by all respondents assigned to block one or block two then there is the potential that besides attributes level combinations, the order in which choice sets were presented influenced choice rules formulated by respondents to some degree. Such an order effect is referred to as "position order effect" (Day et al., 2012). In a study that sought to assess the position order effect in a repeated choice experiment, Day et al., (2012) found a statically strong evidence that an individual's preference expression differed for two identical choice sets placed at different positions in a repeated choice set. 
In order to assess this potential order effect that may have resulted from not randomizing the order of choice sets presented to respondents, the first choice situation that each respondent answered were separated from the second and third choice situations in each county. In effect, two sub-population classes were created for each county. The utility derived from a choice made between electricity generated from natural gas and wind were modeled for the two subpopulations in each county using the basic multinomial logit model. The multinomial logit model was used because the objective of this test was only to test for statistical differences that may exist between the choices made by the two sub-populations in each county. The multinomial logit models estimated for the first choice sets, second and third choice sets (pooled together) and the pooled model of all three choice sets of each respondent in each county are presented in appendix IX.

The null hypothesis of equality between the utility models estimated using only first choice set observations of all respondents and the observations from choices made on the second and third choice sets were tested using the log likelihood test (pooled vs. independent models). In both counties, the null hypothesis of equality between the choices made by two sub-populations could not be rejected (Monongalia County $\left(\chi_{219}=12.87 ; \mathrm{p}\right.$ value $\left.=0.8452\right)$ and Grant County $\left(\chi_{219}=7.54 ; \mathrm{p}\right.$ value $=0.9907)$ at $95 \%$ confidence interval. In other words, the potential for choice set order impacts does not seem to exist in this study. This results was not surprising since the choice experiment designed used for this study was an orthogonal and optimal design. Optimal choice sets design are assumed to be free of order effects (Day, et al., 2012; Kuhfeld, 2005). 


\subsubsection{Effect of Perceived Positive Employment Impact of Coal on Choices}

Since the coal industry in West Virginia significantly impacts the state's economy, it was reasonable to assume that respondents' perceptions on the positive impact of electricity generated from coal on employment (job creation) relative to other energy sources (wind and natural gas) may influence the choices made in the choice experiment section. Respondents' perceptions of the positive impact of electricity generated from coal on employment was highly correlated with two other variables that captured all the negative impacts of electricity generated from wind (neg impacts wind) and natural gas (neg impacts ngas)7. In order to avoid collinearity between independent variables neg impacts wind, neg impacts ngas and the variable that captured respondents' perceived positive impact of electricity generated from coal on employment (coaljobs), the variable coaljobs was dropped from the final utility model of this study.

An alternative model that assessed respondents' perceived positive impact of electricity generated from coal on employment and how it impacts the utility derived from a choice of wind relative to natural gas is presented in this section. Using contingency tables, respondents' perceived positive impacts of employment derived from electricity generated from coal relative to other sources (wind and natural gas) and choices made (wind vs. natural gas) were assessed within both county's population ${ }^{8}$. The results of this analysis are presented in table 6.14. From table 6.14, it is evident that a higher percentage of the sampled population in both counties (Monongalia: 64.4\% and Grant: 78\%) perceived that electricity generated from coal has the most positive impact on employment.

\footnotetext{
${ }^{7}$ The variables (neg impacts wind) and (neg impacts ngas) have been explained in detail in section 6.1 and table 6.3.

${ }^{8}$ Respondents who did not know their opinions on job creation impacts were omitted from the analysis of potential employment impacts on choices made in the choice experiment section.
} 
The null of hypothesis of independence between respondents' perceived positive impact of electricity generated from coal on employment and options chosen in the choice experiment section were assessed for each county's population separately. Within each county's sampled population, respondents' perceived positive impacts of electricity generated from coal on employment and the choices made (wind vs. natural gas) in the choice experiment section were not statistically independent of each other. Yet, within the sampled population in Monongalia County, the choice between the wind option and natural gas option were similar for the respondents who asserted that electricity generated from coal had the most positive impact on employment (wind option: 51\% vs. natural gas: $49 \%$ ). On the other hand, the wind option was chosen $10 \%$ more than the natural gas option (wind option: 55\% vs. natural gas: $45 \%$ ) by the respondents in Grant County who asserted that electricity generated from coal had the most positive impact on employment.

Table 6.14. Assessment of choices made vs. opinions on the employment impact of electricity generated from coal.

\begin{tabular}{|c|c|c|c|c|c|c|}
\hline \multirow[b]{3}{*}{$\begin{array}{c}\text { Most Positive } \\
\text { Impact on Jobs } \\
\text { (Electricity } \\
\text { Generation Source) }\end{array}$} & \multicolumn{3}{|c|}{ Monongalia County } & \multicolumn{3}{|c|}{ Grant County } \\
\hline & \multicolumn{2}{|c|}{ Choice Options } & \multirow[b]{2}{*}{$\begin{array}{l}\text { Number of } \\
\text { Choice } \\
\text { Situations }\end{array}$} & \multicolumn{2}{|c|}{ Choice Options } & \multirow[b]{2}{*}{$\begin{array}{l}\text { Number of } \\
\text { Choice } \\
\text { Situations }\end{array}$} \\
\hline & $\begin{array}{l}\text { Wind } \\
\text { Option }\end{array}$ & $\begin{array}{l}\text { Natural } \\
\text { Gas } \\
\text { Option }\end{array}$ & & $\begin{array}{l}\text { Wind } \\
\text { Option }\end{array}$ & $\begin{array}{l}\text { Natural } \\
\text { Gas } \\
\text { Option }\end{array}$ & \\
\hline $\begin{array}{c}\begin{array}{c}\text { Wind or Natural } \\
\text { gas }\end{array} \\
\end{array}$ & $24 \%$ & $11 \%$ & 247 & $14 \%$ & $7 \%$ & 194 \\
\hline Coal & $33 \%$ & $32 \%$ & 453 & $43 \%$ & $35 \%$ & 716 \\
\hline $\begin{array}{c}\text { Number of Choice } \\
\text { Situations }\end{array}$ & 300 & 400 & 700 & 522 & 388 & 919 \\
\hline Chi-squared [1] & & 22.77268 & & & $8.40741^{* *}$ & \\
\hline
\end{tabular}


In an alternative multinomial logit model of utility derived from choices made by respondents, the variable coaljobs, which captured respondents' perceived positive impacts of electricity generated from coal on employment relative to all other sources (wind and natural gas) was included in the model ${ }^{9}$. The results of this multinomial logit model is presented in table 6.15 below.

Table 6.15. Multinomial logit models of Grant County and Monongalia County sampled populations assessing Coal Jobs Impact on Choice.

\begin{tabular}{|c|c|c|}
\hline VARIABLE & $\begin{array}{l}\text { MONONGALIA } \\
\text { COUNTY SAMPLE }\end{array}$ & $\begin{array}{c}\text { GRANT COUNTY } \\
\text { SAMPLE }\end{array}$ \\
\hline WIND_MODERATE & $0.326 * * *$ & -0.083 \\
\hline WIND_FAR & 0.150 & $0.236 * * *$ \\
\hline NGAS_MODERATE & $-0.213^{*}$ & $-0.192 * *$ \\
\hline NGAS_FAR & $0.608 * * *$ & $0.422^{* * *}$ \\
\hline ASC_WIND & $1.949 * * *$ & 0.917* \\
\hline FEES & $-0.086 * * *$ & $-0.096 * * *$ \\
\hline AVERAGE BILL & $-0.004 * *$ & -0.001 \\
\hline SUPPORT_ARPS & $1.018^{* * *}$ & 0.128 \\
\hline COALJOBS & -0.179 & $-0.392 * *$ \\
\hline SEECOAL_H & -0.315 & 0.126 \\
\hline SEEWIND_H & 0.104 & $-0.774 * * *$ \\
\hline CONCERN_BILL & $-0.500 * *$ & 0.056 \\
\hline INVEST_LESS POLLUTION & 0.283 & $0.527 * * *$ \\
\hline NEG ATTITUDE COAL & $0.938 * *$ & $0.787 * * *$ \\
\hline GENDER & $0.372 * *$ & 0.240 \\
\hline AGE & $-0.020 * * *$ & -0.002 \\
\hline ENV AFFILIATION & 0.353 & $-1.405^{* * *}$ \\
\hline 4 YEAR COLLEGE & -0.285 & $-0.517 * * *$ \\
\hline NUMBER OF OBSERVATIONS & 700 & 910 \\
\hline LOG LIKELIHOOD & -375.72 & -537.15 \\
\hline
\end{tabular}

$* * * 1 \%$ significance, $* * 5 \%$ significance, $* 10 \%$ significance

\footnotetext{
${ }^{9}$ The variable that captured all the negative impacts of electricity generated from wind (NEG IMPACTS WIND) and natural gas (NEG IMPACTS NGAS) were omitted for to prevent confounding impacts on the alternative model.
} 
The coefficient of the variable coaljobs was negative and statistically significant at $5 \%$ significance level within the Grant County utility model. In other words, respondents in Grant County who perceived electricity generated from coal as the energy source with the most positive impact on employment derived a negative utility from the choice of the wind option relative to natural gas. The variable coaljobs was not statistically significant in the Monongalia County utility model. The negative and statistically significant coefficient of the variable coaljobs within the Grant County sampled population was not surprising since the variable was partly captured in the neg impacts wind (perceived negative impacts associated with electricity generated from wind) and neg impacts ngas (perceived negative impacts associated with electricity generated from natural gas) variables used in the final mixed logit models. Within the final mixed logit models of each county's sampled population, the coefficient of the variable neg impacts wind was negative and statistically significant.

Respondents were allowed to choose only one energy source (wind, natural gas or coal) that impacts each category presented (seven categories of impacts) most negatively ${ }^{10}$. As a result, respondents who perceived electricity generated from coal as the energy source with the most positive impact on employment were more likely to choose either wind energy or natural gas as the generation source that impacts employment most negatively. In other words, the variable that captured the negative impacts of electricity generated from wind (neg impact wind) and natural gas (neg impact ngas) to some degree also captured the variability in respondents' perception of employment impacts associated with electricity generated from coal. Hence, not explicitly including the variable coaljobs in the final mixed logit models used in this study did not

\footnotetext{
${ }^{10}$ Details on the categories of impacts that were presented to respondents can be found in section 5 of this study. The results of respondents' perceived positive and negative impacts associated with all three energy sources (coal, wind and natural gas) are presented in table 5.12 and 5.13.
} 
dramatically impact the utility that an individual derived from a choice of wind relative to natural gas in the choice experiment section.

\subsubsection{Assessing the Effect of Weighting Observation}

The final choice experiment models presented in this study did not included weighted observations to account for the over sampling of highly educated and older respondents. As discussed earlier in the survey results section, the choices made between the wind option and natural gas option by the educated and older population in each county were not dramatically different from those made by the younger and less educated populations of the respective counties. In order to assess the impact of not weighting observations in the final models used in this study, two multinomial logit models of utility derived from choices made were developed for each county. One model was weighted to account for over sampling of educated and older respondents, while the other model was not weighted to account for over sampling bias.

The results of these models are presented in appendix X in the appendix section. Assessing each county's multinomial logit models (weighted vs. unweighted), it was evident that weighting the observations to account for oversampling bias did not dramatically impact the utility derived from choices made by respondents. Within each county's population, the signs of the statistically significant coefficients estimated in the weighted and unweighted utility models were the same.

Even though the final mixed logit models used in this study were not weighted, in order to extrapolate the economic implications from this study to both counties total population, the final WTP computations were weighted to reflect each target county's population demographic dynamics. 


\section{Chapter 7}

\section{Conclusions, Policy Implications, and Limitations}

This study sought to assess consumers' preferences and WTP for renewable and alternative electricity in West Virginia. The study was motivated by the recently repealed ARPS, which was passed in West Virginia in 2009. As West Virginia struggles to find a balance between a cleaner environment and its energy portfolio, it is hoped that the results of this study, being the first to assess consumer demand and preference for renewable and alternative electricity in West Virginia, will provide some insights about public perceptions of these energy sources for electricity. These insights will enlighten future discussions on renewable portfolio standard within the state.

The West Virginia ARPS was repealed for a number of reasons. Most importantly, legislators and lobbyists claimed there was the need to protect coal mining jobs that would be lost and also to avert any burdens from potential increases in the electricity bill for the average end users that may stem from the enforcement of the ARPS (West Virginia Chamber of Commerce \& West Virginia Business Industry Council, 2015). It should be noted that the director of West Virginia Division of Energy (Jeff Herdhold) stated during a senate committee meeting that: "This bill is aimed at incentives for clean coal projects" and utility providers in the state were not projected to face any hardship as a results of the policy enforcement (Garvin, 2009). Even though an assessment of claims made by those who opposed the implementation of the ARPS policy was not part of the objectives of this study, the results of this study shed some insight into consumers' general attitudes and preferences for environmentally cleaner sources of electricity in West Virginia.

The results from this study showed that the majority of the sampled populations in both Monongalia County (56.0\%) and Grant County (59.0\%) had not heard about the ARPS. After briefly 
explaining the ARPS in the survey, respondents were asked if they supported this policy and its objectives. Disregarding respondents who were not sure about their support for the ARPS policy (Monongalia County: 35\%; Grant County: 48\%), more than half of the respondents who expressed an opinion in Monongalia County (63\%) and Grant County (58\%) supported the ARPS policy and its objectives. The Center for Business and Economic Research (Center for Business and Economic Research, 2006), in a study on consumers' preferences for renewable energy in West Virginia, found a similar result where the majority (77.8\%) of the population surveyed across the state supported the idea that the state should promote the purchase of renewable energy by business and home owners. A renewable energy portfolio standard is one method to promote the purchase of electricity generated from renewable energy.

Clearly, the sampled populations in the two counties support increasing the share of renewable energy in the state's energy portfolio for a number of reasons. Yet, a high percentage of the sampled population had never heard of the ARPS policy, which was passed in 2009 by the state's legislature. The West Virginia ARPS policy was passed in a special session which are brief compared to regular legislative sessions. According to an editorial in the West Virginia Highland Voice, there was limited debate on the policy in the state senate and a few opportunities were available to influence the outcome before it was passed (Garvin, 2009). As a result, it was not surprising that a high percentage of the sampled population in this study had not heard about the ARPS policy. In order to gain public support and ensure the long-term sustainability of any renewable portfolio standard that may be enacted in West Virginia in the future, it will be prudent for the state legislature to involve the public during the policy debate period. Also, a carefully structured public education on the policy can also be used to inform the public about the benefits of 
the policy. Public involvement could be in a form of inviting comments and public hearing of the intended bill.

Over half of the sampled population in both counties expressed a positive attitude towards electricity generated from wind (Monongalia County: 53.0\%; Grant County: 54.0\%). This result in Grant County was not expected. Given that a wind farm already exist in the county, a "NIMBY" phenomenon was expected. In addition, the impact of the parameter that captured respondent's day to day sighting of wind turbines from their current residence (seewind_h) on utility derived from a choice of $10 \%$ of electricity generated from wind was not statistically significant in both county's utility models. The share of the sampled population in Monongalia County (54.0\%) and Grant County (51.0\%) who expressed a positive attitude towards electricity generated from natural gas were similar to those expressed on electricity generated from wind in both counties.

In order to assess how respondents' attitudes towards electricity generation from coal (the current source of most electricity in West Virginia) influenced the utility derived from a choice of electricity generation option (wind or natural gas), respondents' negative attitude towards electricity generated from coal was included as a variable in the utility models. As expected, respondents who expressed neutral to very negative attitudes towards coal derived positive utility from the choice of renewable electricity (wind) relative to natural gas. This result implied that there was a positive relationship between negative attitudes towards coal (a nonrenewable source of electricity) and the utility derived from electricity generated from wind energy (a renewable energy source). In other words, respondents with negative attitude towards electricity generated from coal derived a positive utility from the wind option.

High percentages of the respondents in both counties (Monongalia County: $72.0 \%$ and Grant County $62.0 \%$ ) were concerned about pollution when it came to electricity generation. A higher 
percentage of the sampled population in Monongalia County (82.0\%) than in Grant County (72.0\%) felt that the state should invest in less polluting electricity generation sources. Even though public support and preferences for a renewable energy policy drives the sustainability of energy policies, without consumers' WTP for the provision of renewable energy, the support for the ARPS and preference for wind in West Virginia will be meaningless under a voluntary program.

When respondents were asked to express their level of agreement to the statement: "I would be willing to pay more for electricity that is generated with less pollution than current energy sources (mainly coal)", much lower percentages of the sampled populations (37\% in Monongalia County and 18\% in Grant County) agreed with this statement than the percentages who expressed concern about pollution from electricity. Clearly, there exists a level of disparity between concerns for the environment and WTP for cleaner electricity generation source exists within the sampled populations in both counties. In a similar study that assessed consumers' attitudes and preferences for renewable energy across the state, the Center for Business and Economic Research (2006) also found a low percentage $(24.1 \%)$ of the surveyed population were willing to pay a premium for renewable and alternative electricity in West Virginia.

Out of the total 1,069 and 1,403 choice situations completed in Monongalia County and Grant County respectively, the majority of the respondents in Monongalia County (62\%) and Grant County $(60 \%)$ choose wind over natural gas as the energy source that should be used to generate $10 \%$ of the electricity supplied to them. Moreover, the choice of the wind option relative to the base case of natural gas positively impacted individuals' utility. Based on these results, it can be asserted that there was preference for wind over natural gas as the energy source that should be used to generate electricity under the ARPS. In a similar study that sought consumers' preference for renewable energy across the state, $69.2 \%$ of the surveyed population supported building more 
large scale wind farms as an economic development strategy (Center for Business and Economic Research, 2006).

Even though some level of disparity exists between concerns for the environment and WTP for cleaner electricity generation source within the sampled populations in both counties, respondents were willing to pay a positive premium per month for $10 \%$ of electricity generated from wind relative to natural gas. Respondents in Monongalia and Grant Counties, on average, were willing to pay $\$ 21.59$ and $\$ 9.87$ per month respectively on top of their current electricity bill for $10 \%$ of the electricity that is supplied to their residence to be generated from wind energy. Even though the weighted mean WTP per month for $10 \%$ of electricity generated from wind in Monongalia County was significantly higher than the sampled population in Grant County, these averages were not statistically different from each other. Thus, average WTP was not impacted by county location and the differences in existing wind facilities. As a result, a strict NIMBY effect for electricity generated from wind could not be established between the two counties.

One of the main objectives of this study was to assess whether West Virginia residents express preferences for proximity as an attribute of renewable and alternative electricity generation sources. Results from the econometric model estimation showed that proximity as an attribute of electricity generation is an important determinant of utility derived from the choice of wind or natural gas option for both counties. The parameter estimate for the farthest proximity levels of both electricity generation sources were positive and statistically significant in each county model.

In general, the weighted mean WTP for each county's sampled population increased as the distance of the newly sited location of an electricity generation source (wind and natural gas) increased from the baseline location of "near" their current residence. The sampled population in 
Monongalia County were willing to pay weighted mean premiums of $\$ 7.74$ and $\$ 10.14$ per month for wind turbines to be located at moderate and far away locations, respectively. Similarly, on average, the sampled population in Grant County were willing to pay weighted premiums of $\$ 7.39$ and $\$ 11.71$ per month to locate wind turbines at the moderate and far proximity levels, respectively. Respondents mean WTP per month to locate a natural gas-fired power plant at the moderate and far proximity levels were slightly higher within the Grant County sampled population (moderate: \$6.58 and far: \$13.47) compared to the sampled population in Monongalia County (moderate: \$4.14 and far: \$13.06).

Evidently, there was a preference among respondents for the farthest location relative to the baseline proximity of near for both wind farms and a natural gas-fired power plant among both county populations. The weighted mean WTP for the farthest location of wind turbines relative to the baseline for the two counties were statistically different from each other. In other words, the sampled population in Grant County valued the farthest location of wind turbines slightly more than Monongalia County sampled population. This result was attributed to the Grant County sampled population's familiarity with the visual disamenities associated with an existing wind farm. Compared to the baseline location, each county's sampled population on average valued the farthest location of a natural gas-fired power plant slightly higher than the farthest location of wind turbines.

On an adjusted household basis, there were positive social benefits derived from generating $10 \%$ of electricity supplied to consumers from wind relative to natural gas in both counties. A significantly higher social benefit was derived within Monongalia County compared to Grant County. The total household WTP per year for $10 \%$ of electricity generated from wind relative to natural gas for Monongalia County and Grant County were $\$ 2.5$ million and $\$ 186$ thousand 
respectively. On a per capita basis, the aggregated WTP per year for $10 \%$ of electricity generated from wind relative to natural gas was found to be over twice as large in Monongalia County (\$98.18) than as in Grant County (\$44.15). Despite this large difference, the annual aggregated WTP per capita for $10 \%$ of electricity generated from wind relative to natural gas for the two counties were not statistically different from each other.

The aggregate social benefits derived in both counties from a choice of $10 \%$ of electricity generated from wind or natural gas increased as the proximity of the respondent's residence to the location of the hypothetical electricity generation facility decreased. The aggregate households' WTP per year to locate wind turbines at the moderate and far proximity levels relative to the baseline location were $\$ 915$ thousand and $\$ 1.2$ million, respectively for the Monongalia County households. The adjusted total household WTP for locating wind turbines at the moderate and far proximity levels relative to the baseline in Grant County were $\$ 139$ and $\$ 221$ thousand dollars per year, respectively.

Similarly, there were positive social gains derived from locating a natural gas-fired power plant away from the current residence of respondents in both counties. The highest social gains in each county were derived from the farthest location of a natural gas-fired facility relative to the baseline location. The aggregate households WTP per year to site a natural gas fired power plant at the farthest location away from respondents' residence was $\$ 1.54$ million and $\$ 254$ thousand for the Monongalia County and Grant County populations, respectively. As with wind energy, the differences between counties for social benefits derived from proximity as an attribute of electricity generation facilities was based on a much larger population in Monongalia County.

The significantly higher aggregate WTP for the farthest location of an electricity generation facility relative to the baseline location and wind as an energy source presents an important criteria 163 
to consider in any future renewable portfolio standard that may be considered by the legislators in West Virginia. The results show that proximity as an attribute of wind turbines and a natural gasfired power plant is an important attribute that influence consumers' choice for environmentally benign sources of electricity generation. Moreover, electricity from wind turbines generated the highest social benefits in both counties. In the future, if legislators in West Virginia should again seek to expand the state's renewable electricity portfolio, this study has shown that focusing the portfolio on wind as an energy source and siting wind turbines farther away from the majority of households will be an important criteria to consider in order to maximize the social benefits that will be derived from the policy as a whole.

Based on the results presented in this study, it is clear that that majority of the sampled population who expressed an opinion about the ARPS supported the policy. The surprisingly high percentage of the sampled population who have not heard about the currently repealed ARPS suggests that some form of information dissemination gap exists within the population surveyed in this study and the state legislature. The sampled population in both counties preferred electricity generated from wind over natural gas. Both counties populations were willing to pay a positive premium for electricity generated from wind and derived a positive social benefit from electricity generated from wind.

In the future, if a renewable portfolio standard is ever considered again by the West Virginia legislature and the long term sustainability of the policy is a major objective of legislators, then a carefully structured public education on the policy and its objectives before its implementation may be necessary to avoid public opposition and misconception. Moreover, a push towards using wind energy to meet any renewable portfolio standard that may be enacted in the state in the near future over natural gas will increase the gains in utility and social benefits that may be derived from the 
policy. Such a policy with wind energy as its focus will invariably be supported by consumers of electricity in West Virginia.

Lastly, this study contributes to the existing literature on consumers' attitudes and willingness to pay for relatively cleaner sources of electricity significantly. The specific contributions of this study to existing literature on consumers' willingness to pay for renewable and alternative source of electricity are as follows:

1. Based on a thorough literature review, this study is the first that has attempted to compare estimates of consumers' WTP for proximity as an attribute of a natural gas-fired power plant and wind together.

2. Based on a thorough literature review, this research is the first that has attempted to explicitly assess the impact of existing electricity generation facilities (coal power plant and wind farms) on consumers' WTP for a hypothetical renewable (wind energy) and alternative energy (natural gas).

3. This study is the first study that has attempted to estimate consumers' WTP for renewable electricity in West Virginia and its policy implication. 


\subsection{Policy Implication: The ARPS Policy Repeal vs. Voluntary Green Pricing Policy}

Enormous evidence from this study suggests that a significant share of consumers in both counties surveyed have positive attitudes towards electricity generated from wind energy (Monongalia County: 53.0\%; Grant County: 54.0\%) and natural gas (Monongalia County: 54.0\%; Grant County: 51.0\%). At least a third of the sampled population in both counties supports the ARPS policy. Respondents preferred $10 \%$ of the electricity generated supplied to them to be generated from wind and were willing to pay a positive premium on top of their electricity bill for this service. On aggregate, a substantial social benefit was be derived from generating $10 \%$ of electricity supplied to consumers from wind relative to natural gas in both counties. Based on the significant preference for electricity generated from wind, positive mean WTP for $10 \%$ of electricity generated from wind and the aggregate positive social benefit derived from the choice of wind option in both counties surveyed, it can be asserted that a renewable portfolio standard with wind energy as its focus will be sustainable in the long term in both Monongalia County and Grant County.

The majority of sampled population surveyed in Monongalia County (81\%) and Grant County (72\%) agreed (somewhat to strongly) to the statement; "It is important to invest in power plants that generate the least amount of pollution". Moreover, the majority of the sampled population in Monongalia County (74.0\%) and Grant County (62.0\%) agreed to the statement "I am concerned about pollution created by electricity generation". Although the electricity market in West Virginia is not a deregulated market, more than half of the respondents in Monongalia County (51.0\%) and Grant County (61.0\%) agreed to the statement; "Each consumer should be able to choose the electricity generation source that he or she prefers". A similar observation was reported in a survey 
on West Virginians attitudes and preferences from renewable energy efficiency by the Center for Business and Economic research in 2006. This study found that $86.6 \%$ of the respondents sampled across the state felt that the state policy should allow electric utility customers to buy renewable and alternative energy (Center for Business and Economic Research, 2006).

From the observations above, it is logical to assert that a sizable share of the populations in Monongalia and Grant Counties were concerned about pollution associated with electricity generation and have a preference for cleaner sources of electricity generation. Beyond concerns for the environment when it comes to electricity generation, a sizable share of the population in both counties believed that they should be given a choice to choose the electricity generation source preferred. In light of the recent repeal of the ARPS policy in West Virginia and the potential significant social benefits that may be derived from electricity generated from wind as shown in this study, a logical policy alternative to consider in the near future in West Virginia is a "voluntary green pricing" program for consumers who are willing to pay a premium for renewable electricity.

The outright repeal of the ARPS policy basically implied that there are no social benefits derived from cleaner electricity generation sources in the state. Providing consumers the option to voluntarily opt into a green pricing program and pay an additional premium on top of their electricity bill will increase the renewable electricity generation capacity in West Virginia in the long run. Given that participants who voluntarily opt into such programs have concerns for the environment and will like to contribute to a cleaner environment, such a program will be favorable and also sustainable in the long run ${ }^{11}$.

\footnotetext{
${ }^{11}$ In September 2008, Appalachian Power and Wheeling Power (owned by American Electric Power), launched a voluntary green pricing programs in West Virginia but ended the program in December 2014.
} 
Green pricing is a voluntary program that offers consumers a choice for electricity generation sources. Usually for a premium, participating consumers' can choose a share (if not $100 \%$ ) of their monthly electricity use to be supplied from renewable energy sources. Within existing voluntary green pricing programs across the United States, two products are available to residential customers. The program is either established in such a way that consumers can choose a percentage of their monthly electricity use from green power (percentage-of-use products) or purchase a discrete block of green power at a fixed price (block products) (Heeter \& Bird, 2013). For example, a consumer can choose a certain number of $100 \mathrm{kWh}$ blocks at a fixed price per month. Within the percentage of use product programs, residential consumers have been allowed to choose $10 \%, 25 \%, 50 \%$ or $100 \%$ of their electricity use per month from green program (Heeter \& Bird, 2013). Even though the electricity supplied to consumers may not be directly generated from renewable sources, such premiums are seen as a contribution towards increasing the renewable share of electricity generated.

These programs have expanded steadily across the U.S. over the years. As of 2015, approximately 850 utilities across the country participated in green market programs (U.S. Department of Energy, 2015). This is up from just 90 utilities in 2002 (Wiser et al. 2008). Figure 7.1 depicts the steady nationwide growth in green pricing programs between 2006 and 2010 . According to the U.S. EIA, approximately 1.2 million electricity customers in United States participated in a green pricing program in 2010 (U.S. Energy Information Administration, 2012b). This represented about an $8 \%$ growth from the previous year.

A number of studies have sought to identify why consumers of electricity choose to participate in green pricing programs. Kotchen and Moore (2007) identified concerns for the environment and strong altruistic attitudes as the two main reason why a household would choose 
to participate in a voluntary green pricing program. Wiser (1998) asserted that green power provision (demand) is analogous to the provision of public good and an individual does not participate for the sole purpose of private benefits but also derives utility from nontraditional private benefits such as altruism and social acceptance. As a result, it is important to focus on factors that will increase public good provision participation when considering green power marketing (1998). These include marketing strategies such as social pressure, assuring consumers of being an integral part of making the environment much greener and enhancing the private value gained from participating in green pricing programs. Kotchen and Moore (2007), on the other hand, emphasized targeting consumers with characteristics that makes them more likely to participate in green pricing programs. Kotchen and Moore (2007) advised that green pricing programs should target households with: (1) high incomes, and (2) environmental organization members.

Even though a high percentage of the sampled population in both counties expressed concern for the environment and pollution associated with electricity generation in the state, only $37 \%$ of the sampled population in Monongalia County and 18\% in Grant County agreed to the statement that "I would be willing to pay more for electricity that is generated with less pollution than current energy sources (mainly coal)”. Obviously, a huge disparity existed between respondents' concern for the environment and their WTP for less polluting source of electricity generation. As a result, its logical to suggest that respondents who exhibited traits of concern for the environment and are willing to pay a premium for less polluting electricity generation sources may be the most likely candidates for a voluntary green pricing programs in both counties. 


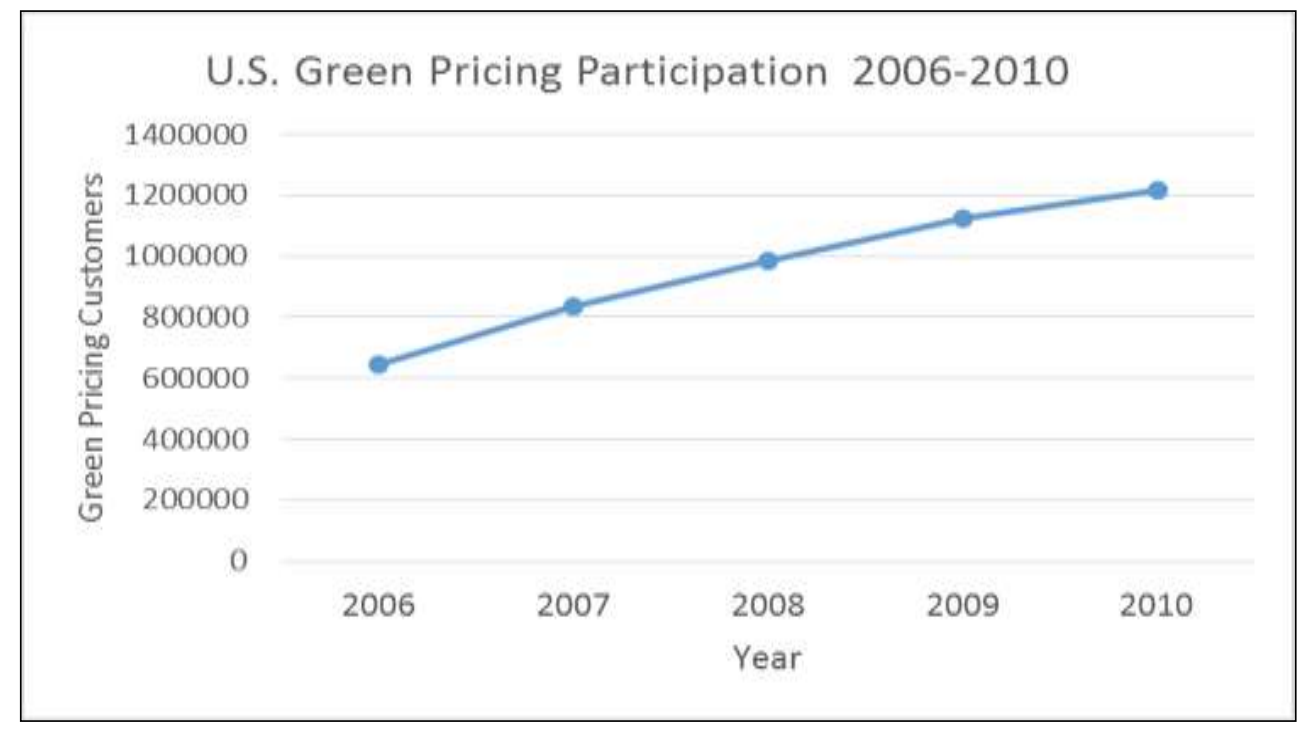

Figure 7.1. United States green pricing participation.

In 2012, participating residential consumers in green pricing programs paid premiums that ranged between -0.87 cents $/ \mathrm{kWh}$ (premium below standard rates) to +4.61 cents per $/ \mathrm{kWh}$ (premium above standard rates). The average premium was 1.58 cents/kWh above standard rates. On average, participating residential customers of green pricing programs paid $\$ 6.30$ per month above standard rate in $2012^{12}$. According to the U.S. EIA, residential consumers in the United States, on average, paid $\$ 107.28$ per month for electricity use in 2012 (U.S. Energy Information Administration, 2012a). This average green pricing program premium represents about 5.9\% of the average electricity bill paid by residential customers across the country in 2012 . On average, residential customers in West Virginia paid $\$ 106.15$ per month for electricity use (U.S. Energy Information Administration, 2012a). The mean WTP for 10\% of electricity generated from wind relative to natural gas within the sampled population in Monongalia County and Grant County

\footnotetext{
${ }^{12}$ This dollar value does not account for the percentage use or Kwh-blocks purchased
} 
represents $20.3 \%$ and $9.2 \%$ of the average residential electricity bill per month paid by West Virginians in 2012 respectively.

Comparing the average premium paid per month by green pricing program participants in 2012 across United States to the results from this study, the mean WTP for $10 \%$ of electricity generated from wind in Monongalia County was found to be substantially higher than the actual average premiums per month paid by residential consumers nationally in 2012 . The mean WTP for $10 \%$ of electricity generated from wind within the Grant County population was slightly higher, but not substantially higher than the average premiums per month paid by green pricing program participants in the United States. This study has shown that respondents in the two counties that we surveyed were, on average, willing to pay higher premiums per month for renewable electricity that are comparable to the national average for green pricing programs. As a result, a voluntary green pricing program established in West Virginia has the potential to be sustainable in the long term.

Lastly, in order to justify the extrapolating of policy implications of this study to the rest of the state of West Virginia, respondents' opinions on renewable energy expressed in this study were compared to a state-wide study of consumer's attitudes towards renewable energy conducted by the Center for Business and Economics (CBER, 2006). Respondents' opinions to questions related to the need to invest in less polluting energy source, support for new wind farms and willingness to pay a premium for less polluting energy source were compared to the CBER (2006) study. Moreover, the socio-demographic statistics of the sampled population in this study were compared to that of CBER (2006) study.

After the assessing the socio-demographic statistics and trends in opinions expressed by the sampled population of this study and the state wide study conducted by CBER (2006), it was 
evident that the Grant County sampled population's opinions was more likely to be reflective of West Virginia's population than the Monongalia County sampled population. A detailed assessment of the similarities in opinions expressed on renewable energy and socio-demographic characteristics of the sampled population in this study and the CBER (2006) statewide study is presented as appendix XI in the appendix section.

\subsection{Some Limitations of Study}

Even though the West Virginia ARPS was a statewide policy, the results of this study cannot be generalized to the whole state of West Virginia. It's limited to only the two counties surveyed in this study. Future research should explore options to include the rest of the state in its sampling in order to extrapolate the results of this study to reflect the opinions of consumers across the state.

Secondly, attempts to test for possible hypothetical bias that may have existed in our data was not successful using mixed logit estimation. Estimation difficulties relating to a flat log likelihood of the mixed logit models for respondents who were certain and uncertain about their choices made this task impossible. As a result, a multinomial logit model was used to address hypothetical bias that may have existed in the models presented in study. The use of a multinomial logit model meant that possible preference heterogeneity could not be modeled within the population who were certain or uncertain about tier choice in this test.

Lastly, as a result of logistic difficulties and some circumstances beyond the researcher's control (focus group meetings scheduling), the commencement and end date of this study included Thanksgiving and the Christmas holiday season (November 1st, 2013 and March 15 ${ }^{\text {th }}, 2014$ ). This period in which we conducted the survey may have affected the response rate of this study. Dillman (2000) strongly suggests that researchers should avoid sending surveys to respondents during this 
period. Respondents are usually busy preparing for the holiday and the amount of mail volume that the holidays presents to respondents makes such a period very difficult to respond to a survey.

Ladenburg and Dubgaard (2007) in their study that sought consumers' WTP for reduced visual disamenities from wind turbines in Denmark reported a response rate of $51.7 \%$. This study commenced in May 2004. In a similar and recent study on consumers' WTP for reducing visual diamenities from wind in Delaware, Krueger et al., (2011) also reported a response rate of 52.0\%. This study commenced on, September 9th 2006 and ended on December 31st 2006 . The response rate of this study for Monongalia County and Grant County were approximately $23 \%$ and 15\% respectively less than the two studies presented above. 


\section{References}

Abbasi, S. A., \& Abbasi, N. (2000). The likely adverse environmental impacts of renewable energy sources. Applied Energy, 65(1-4), 121-144. doi: 10.1016/s0306-2619(99)00077-x

Alpizar, F., Carlsson, F., \& Martinsson, P. (2001). Using Choice Experiments for Non-Market Valuation: Göteborg University - School of Economics and Commercial Law/Department of Economics.

Alternative and Renewable Energy Portfolio Act., W. Va. Code § 24-2F-12 Stat. (2009).

Álvarez-Farizo, B., \& Hanley, N. (2002). Using conjoint analysis to quantify public preferences over the environmental impacts of wind farms. An example from Spain. Energy Policy, 30(2), 107-116.

American Wind Energy Association. (2015). U.S. Wind Energy State Facts Retrieved July, 11, 2015, from http://www.awea.org/resources/statefactsheets.aspx?itemnumber $=890$; http://awea.files.cms-plus.com/FileDownloads/pdfs/West\%20Virginia.pdf

Aravena, C., Martinsson, P., \& Scarp, R. (2006). The effect of a monetary attribute on the marginal rate of substitution in a choice experiment. Paper presented at the Environmental and Resource Economist 3rd World Congress., Kyoto, Japan.

Bech, M., \& Gyrd-Hansen, D. (2005). Effects coding in discrete choice experiments. Health economics, 14(10), 1079-1083.

Bennett, J. (1996). Estimating the recreation use values of national parks. Tourism Economics, 2(4).

Bennett, J., \& Adamowicz, V. (2001). Some Fundamentals of Environmental Choice Modelling. In R. B. Jeff Bennett (Ed.), The choice modelling approach to environmental valuation

(pp. 37-69). Cheltenham: Edward Elgar Publishing

Bennett, J., \& Blamey, R. (2001). The choice modelling approach to environmental valuation. Cheltenham, UK; Northampton, MA, USA: E. Elgar.

Bergmann, A., Colombo, S., \& Hanley, N. (2008). Rural versus urban preferences for renewable energy developments. Ecological Economics, 65(3), 616-625. doi: 10.1016/j.ecolecon.2007.08.011

Bergmann, A., Hanley, N., \& Wright, R. (2006). Valuing the attributes of renewable energy investments. Energy Policy, 34(9), 1004-1014. doi: DOI: 10.1016/j.enpol.2004.08.035

Bhat, C. R. (2001). Quasi-random maximum simulated likelihood estimation of the mixed multinomial logit model. Transportation Research Part B: Methodological, 35(7), 677693.

Bhattacharyya, S. C. (2011). Energy economics concepts, issues, markets and governance, from http://dx.doi.org/10.1007/978-0-85729-268-1

Blamey, R., Gordon, J., \& Chapman, R. (1999). Choice Modelling: Assessing the Environmental Values of Water Supply Options. Australian Journal of Agricultural and Resource Economics, 43(3), 337-357. doi: 10.1111/1467-8489.00083

Bochner, F. F. (2014). Water, Wind, and Fire: A Call for a Federal Renewable Portfolio Standard. Duke Envtl. L. \& Pol'y F., 25, 201. 
Borchers, A. M., Duke, J. M., \& Parsons, G. R. (2007). Does willingness to pay for green energy differ by source? Energy Policy, 35(6), 3327-3334. doi: DOI: 10.1016/j.enpol.2006.12.009

Braunholtz, S. (2003). Public Attitudes to Windfarms: A Survey of Local Residents in Scotland. Edinburgh, : Retrieved from http://scotland.gov.uk/Publications/2003/08/18049/25579.

Breglio, V. J., \& Sustainable Energy Budget Coalition. (1994). Energy : post-election views : a public opinion survey. Lanham, MD: Research/Strategy/Management, Inc.

Brouwer, W. B., Culyer, A. J., van Exel, N. J. A., \& Rutten, F. F. (2008). Welfarism vs. extrawelfarism. Journal of health economics, 27(2), 325-338.

Burall, P. (2004). Putting wind turbines in their place. Town and Country Planning 77(2).

Carley, S. (2009). State renewable energy electricity policies: An empirical evaluation of effectiveness. Energy Policy, 37(8), 3071-3081. doi: 10.1016/j.enpol.2009.03.062

Center for Business and Economic Research. (2006). Attitudes and Awareness of Energy Efficiency and Alternative Energy Resources in West Virginia: Marshall University.

Collins, A., Rosenberger, R., \& Fletcher, J. (2004). Total Economic Valuation of Stream Restoration Using Internet and Mail Surveys. Paper presented at the American Agricultural Economics Association Annual Meeting., Denver, Colorado. http://purl.umn.edu/20402

Database of State Incentives for Renewables and Efficiency, D. (2012, 12/15/2011). Alternative and Renewable Energy Portfolio Standard: West Virginia Incentives/Policies for Renewables \& Efficiency Retrieved 04/04, 2012, from http://www.dsireusa.org/incentives/incentive.cfm?Incentive_Code=WV05R\&RE=1\&EE $=1$

Database of State Incentives for Renewables and Efficiency, D. (2015). Renewable Portfolio Standards Retrieved 06/08, 2015, from http://programs.dsireusa.org/system/program?type $=38 \&$

Day, B., Bateman, I. J., Carson, R. T., Dupont, D., Louviere, J. J., Morimoto, S., . . Wang, P. (2012). Ordering effects and choice set awareness in repeat-response stated preference studies. Journal of Environmental Economics and Management, 63(1), 73-91. doi: http://dx.doi.org/10.1016/j.jeem.2011.09.001

Dear, M. (1992). Understanding and overcoming the NIMBY syndrome. Journal of the American Planning Association, 58(3), 288-300.

Devine-Wright, P. (2005). Beyond NIMBYism: towards an integrated framework for understanding public perceptions of wind energy. Wind Energy, 8(2), 125-139. doi: $10.1002 /$ we. 124

Dillman, D. A. (2000). Mail and internet surveys : the tailored design method. New York: Wiley.

Ek, K. (2005). Public and private attitudes towards "green" electricity: the case of Swedish wind power. Energy Policy, 33(13), 1677-1689. doi: 10.1016/j.enpol.2004.02.005

Ek, K. (2006). Quantifying the environmental impacts of renewable energy: The case Study of Swedish Wind Power. In D. W. Pearce (Ed.), Environmental valuation in developed countries : case studies (pp. 181-210). Cheltenham, UK; Northampton, MA: Edward Elgar. 
Elliott, D. (1994). Public Reactions to Wind farms: the dynamics of opinion formation. Energy and Environment, 5(4), 343-362.

Elliott, D. (2003). Energy, Society and Environment, from http://public.eblib.com/EBLPublic/PublicView.do?ptiID=182516

European Commission. (2003). External Costs: Research Results on Socio-Environmental Damages Due to Electricity and Transport. Brussels.

Farhar, B. C. (1999). Willingness to Pay for Electricity from Renewable Resources: A Review of Utility Market Research (Vol. NREL/TP-550-26148). Colorado: National Renewable Energy Laboratory.

Farhar, B. C., \& Houston, A. H. (1996). Willingness to Pay for Electricity from Renewable Energy (Vol. NREL/TP-460-21216): National Renewable Energy Laboratory.

Firestone, J., \& Kempton, W. (2007). Public opinion about large offshore wind power: underlying factors. Energy Policy, 35(3), 1584-1598.

Freeman, A. M. (2003). The measurement of environmental and resource values : theory and methods. Washington, DC: Resources for the Future.

Garvin, D. S. J. (2009, 07/28). LEGISLATURE FINALLY ADJOURNS. Retrieved from http://wvhighlands.org/wv_voice/?p=1683

Groothuis, P. A., Groothuis, J. D., \& Whitehead, J. C. (2008). Green vs. green: Measuring the compensation required to site electrical generation windmills in a viewshed. Energy Policy, 36(4), 1545-1550. doi: 10.1016/j.enpol.2008.01.018

Hanemann, W. M. (1994). Valuing the Environment Through Contingent Valuation. The Journal of Economic Perspectives, 8(4), 19-43.

Hanley, N., Mourato, S., \& Wright, R. E. (2001). Choice Modelling Approaches: A Superior Alternative for Environmental Valuatioin? Journal of Economic Surveys, 15(3), 435-462. doi: 10.1111/1467-6419.00145

Hanley, N., Wright, R., \& Adamowicz, V. (1998). Using Choice Experiments to Value the Environment. Environmental and Resource Economics, 11(3-4), 3-4.

Heeter, J., \& Bird, L. (2013). Including alternative resources in state renewable portfolio standards: Current design and implementation experience. Energy Policy, 61, 1388-1399.

Hensher, D., Rose, J. M., \& Greene, W. H. (2005). Applied choice analysis: a primer: Cambridge University Press.

Hensher, D., Shore, N., \& Train, K. (2005). Households' willingness to pay for water service attributes. Environmental and Resource Economics, 32(4), 509-531.

Holmes, T. P., \& Adamowicz, W. L. (2003). Attribute-Based Methods. In P. A. Champ, K. J. Boyle \& T. C. Brown (Eds.), A Primer on Nonmarket Valuation. Dordrecht. : Kluwer Academic Publishers.

Holt, M., \& Glover, C. (2006). Energy policy act of 2005: summary and analysis of enacted provisions: Congressional Research Service.

Hurley, J. (2014). Welfarism and Extra-Welfarism. Encyclopedia of Health Economics, 483-489. Hymel, M. (2006). United States' Experience with Energy-Based Tax Incentives: The Evidence Supporting Tax Incentives for Renewable Energy, the. Loy. U. Chi. LJ, 38, 43.

Khan, J. (2003). Wind power planning in three Swedish municipalities. Journal of Environmental Planning and Management, 46(4), 563-581. 
Kikuchi, R. (2008). Adverse impacts of wind power generation on collision behaviour of birds and anti-predator behaviour of squirrels. Journal for Nature Conservation, 16(1), 44-55.

Krohn, S., \& Damborg, S. (1999). On Public Attitudes Towards Wind Power. Renewable Energy, 16(1), 954-960. doi: 10.1016/s0960-1481(98)00339-5

Krueger, A. D., Parsons, G. R., \& Firestone, J. (2011). Valuing the Visual Disamenity of Offshore Wind Power Projects at Varying Distances from the Shore: An Application on the Delaware Shoreline. [Article]. Land Economics, 87(2), 268-283.

Kuhfeld, W. F. (2005). Marketing research methods in SAS. Experimental Design, Choice, Conjoint, and Graphical Techniques. Cary, NC, SAS-Institute TS-722.

Ladenburg, J. (2009). Stated public preferences for on-land and offshore wind power generation-a review. Wind Energy, 12(2), 171-181. doi: 10.1002/we.308

Ladenburg, J., \& Dubgaard, A. (2007). Willingness to pay for reduced visual disamenities from offshore wind farms in Denmark. Energy Policy, 35(8), 4059-4071. doi: 10.1016/j.enpol.2007.01.023

Ladenburg, J., \& Dubgaard, A. (2009). Preferences of coastal zone user groups regarding the siting of offshore wind farms. Ocean \&amp; Coastal Management, 52(5), 233-242. doi: 10.1016/j.ocecoaman.2009.02.002

Lancaster, K. J. (1966). A New Approach to Consumer Theory. The Journal of Political Economy, 74(2), 132-157.

Louviere, J. J. (2001). Choice Experiments: An overview of concepts and Issues. . In R. B. Jeff Bennett (Ed.), The choice modelling approach to environmental valuation (pp. 13-36). Cheltenham: Edward Elgar Publishing

Louviere, J. J., \& Woodworth, G. (1983). Design and analysis of simulated consumer choice or allocation experiments: an approach based on aggregate data. Journal of marketing research, 350-367.

McCartney, A. (2006). The Social Value of Seascapes in the Jurien Bay Marine Park: An Assessment of Positive and Negative Preferences for Change. J Agricultural Economics Journal of Agricultural Economics, 57(3), 577-594.

McFadden, D. (1981). Econometric Models of Probabilistic Choice. In C. F. Manski \& D. McFadden (Eds.), Structural analysis of discrete data with econometric application (pp. 198-272). Cambridge (Mass.) [etc.: MIT Press.

Meyerhoff, J., Ohl, C., \& Hartje, V. (2010). Landscape externalities from onshore wind power. Energy Policy, 38(1), 82-92.

Navrud, S., \& Braten, K. G. (2007). Consumers' Preferences for Green and Brown Electricity: a Choice Modelling Approach. Revue d'Économie Politique(5), 795.

Perman, R. (2003). Natural resource and environmental economics. New York: Pearson Education.

Popkin, J. H., Duke, J. M., Borchers, A. M., \& Ilvento, T. (2013). Social costs from proximity to hydraulic fracturing in New York State. Energy Policy, 62, 62-69.

Public Service Commission of West Virginia. (2012). Alternative and Renewable Energy Resource Planning Assessment.

Public Service Commission of West Virginia. (2014). Alternative and Renewable Energy Resource Planning Assessment. 
Rabe, B. (2007). Race to the Top: The Expanding Role of US State Renewable Portfolio Standards. Sustainable Development Law \& Policy

7(3), 5 .

Ready, R. C., Champ, P. A., \& Lawton, J. L. (2010). Using respondent uncertainty to mitigate hypothetical bias in a stated choice experiment. Land Economics, 86(2), 363-381.

Redlinger, R. Y., Andersen, P. D., Morthorst, P. E., \& United Nations Environment Programme. (2002). Wind energy in the 21 st century : economics, policy, technology, and the changing electricity industry. New York: Palgrave.

Redlinger, R. Y., Andersen, P. D., \& Morthorst, P. R. (2002). Wind energy in the 21 st century. Basingstoke (GB): Palgrave.

Revelt, D., \& Train, K. (1998). Mixed logit with repeated choices: households' choices of appliance efficiency level. Review of economics and statistics, 80(4), 647-657.

Roe, B., Teisl, M. F., Levy, A., \& Russell, M. (2001). US consumers' willingness to pay for green electricity. Energy Policy, 29(11), 917-925. doi: Doi: 10.1016/s03014215(01)00006-4

Rowe, R. D., Lang, C., Chestnut, L., Latimer, D., Rae, D., Bernow, S., \& White, D. (1995). The New York electricity externality study: Oceana Pub.

Schleisner, L., \& Sieverts Nielsen, P. (1997). External costs related to power production technologies. ExternE national implementation for Denmark: Risoe National Lab., Roskilde (Denmark). Systems Analysis.

Scottish Natural Heritage. (2001). SNH's Policy on Renewable Energy Policy In S. N. H. P. S. 01/02 (Ed.).

SPECC, S. P., Enterprise, \& Culture, C. (2004). Renewable energy in Scotland : 6th report, 2004. Edinburgh: Stationery Office.

Sundqvist, T. (2004). What causes the disparity of electricity externality estimates? Energy Policy, 32(15), 1753-1766. doi: 10.1016/s0301-4215(03)00165-4

Sundqvist, T., \& Söderholm, P. (2003). Valuing the environment impact of electricity generation: a critical survey: Sundqvist, T. and Söderholm, P. The Journal of Energy Literature, 2002, VIII, (2), 3-41. Fuel and Energy Abstracts, 44(4), 230. doi: 10.1016/s0140-6701(03)82951-X

Swofford, J., \& Slattery, M. (2010). Public attitudes of wind energy in Texas: Local communities in close proximity to wind farms and their effect on decision-making.

Energy Policy, 38(5), 2508-2519.

Thayer, R. L., \& Freeman, C. M. (1987). Altamont: Public perceptions of a wind energy landscape. Landscape and Urban Planning, 14(0), 379-398. doi: 10.1016/01692046(87)90051-X

Train, K. (2000). Halton sequences for mixed logit. Department of Economics, UCB.

Train, K. E. (2009). Discrete choice methods with simulation: Cambridge university press.

U.S. Census Bureau. (2013). State and County QuickFacts

Retrieved August 1st ,, 2014, from http://quickfacts.census.gov/qfd/states/54/54023.html 
U.S. Energy Information Administration. (2010a). 2016 Levelized Cost of New Generation Resources from the Annual Energy Outlook 2010 Retrieved June, 30, 2015, from http://www.eia.gov/oiaf/archive/aeo10/electricity_generation.html

U.S. Energy Information Administration. (2010b). State electric retail choice programs are popular with commercial and industrial customers Retrieved June, 30, 2015, from http://www.eia.gov/todayinenergy/detail.cfm?id=6250\#tabs_RenewablesMaps-4

U.S. Energy Information Administration. (2012a). Annual Energy Review (2011)

Retrieved from http://www.eia.gov/totalenergy/data/annual/pdf/aer.pdf.

U.S. Energy Information Administration. (2012b). West Virginia Electricity Profile 2012 Retrieved June 9, 2015, from http://www.eia.gov/electricity/state/westvirginia/

U.S. Energy Information Administration. (2014). 2012 Average Monthly Bill- Residential Retrieved Augustt 1st, 2014, from http://www.eia.gov/electricity/sales_revenue_price/pdf/table5_a.pdf

U.S. Energy Information Administration. (2015a). Annual Energy Outlook 2014 with Projections to 2040 Retrieved 06/08, 2015, from http://www.eia.gov/forecasts/aeo/pdf/0383(2014).pdf

U.S. Energy Information Administration. (2015b). Energy Explained Retrieved April, 11, 2016, from http://www.eia.gov/energyexplained/index.cfm?page=renewable_home

U.S. Energy Information Administration. (2015c). Energy Overview. Monthly Energy Review May 2015 Retrieved June 8, 2015, from http://www.eia.gov/totalenergy/data/monthly/pdf/sec1.pdf

U.S. Energy Information Administration. (2015d). Monthly Energy Review May 2015.

U.S. Energy Information Administration. (2015e). West Virginia: State Profile and Energy Estimates Retrieved June, 30, 2015, from http://www.eia.gov/state/?sid=WV

U.S. Environmental Protection Agency. (2014). The Emissions \& Generation Resource Integrated Database (eGRID) (eGRID2010 Version 1.1 ed.): U.S. EPA.

Van der Horst, D. (2007). NIMBY or not? Exploring the relevance of location and the politics of voiced opinions in renewable energy siting controversies. Energy Policy, 35(5), 27052714. doi: 10.1016/j.enpol.2006.12.012

Warren, C., Lumsden, C., O'Dowd, S., \& Birnie, R. (2005). Green On Green': Public perceptions of wind power in Scotland and Ireland. Journal of Environmental Planning and Management, 48(6), 853-875. doi: 10.1080/09640560500294376

West Virginia Chamber of Commerce, \& West Virginia Business Industry Council. (2015). Moving West Virginia forward 2015 legislative highlights.

West Virginia Department of Commerce. (2012). West Virginia Energy: Renewable Energy. Retrieved 03/12, 2012, from http://www.wvcommerce.org/energy/renewable_energy/default.aspx

West Virginia Geological and Economic Survey. (2015). Oil \& Gas Data Counts. http://www.wvgs.wvnet.edu/pipe2/stats/tblcnts/tablecountsmain.aspx

West Virginia Highlands Voice. (2008). CONSERVANCY SHIFTS POLICY ON WIND ENERGY Retrieved July 13th, 2015, from http://wvhighlands.org/wv_voice/?p=651 
Wiser, R. H. (2007). Using contingent valuation to explore willingness to pay for renewable energy: A comparison of collective and voluntary payment vehicles. Ecological Economics, 62(3-4), 419-432. doi: DOI: 10.1016/j.ecolecon.2006.07.003 


\section{APPENDICES}

\section{APPENDIX I: The mail survey}

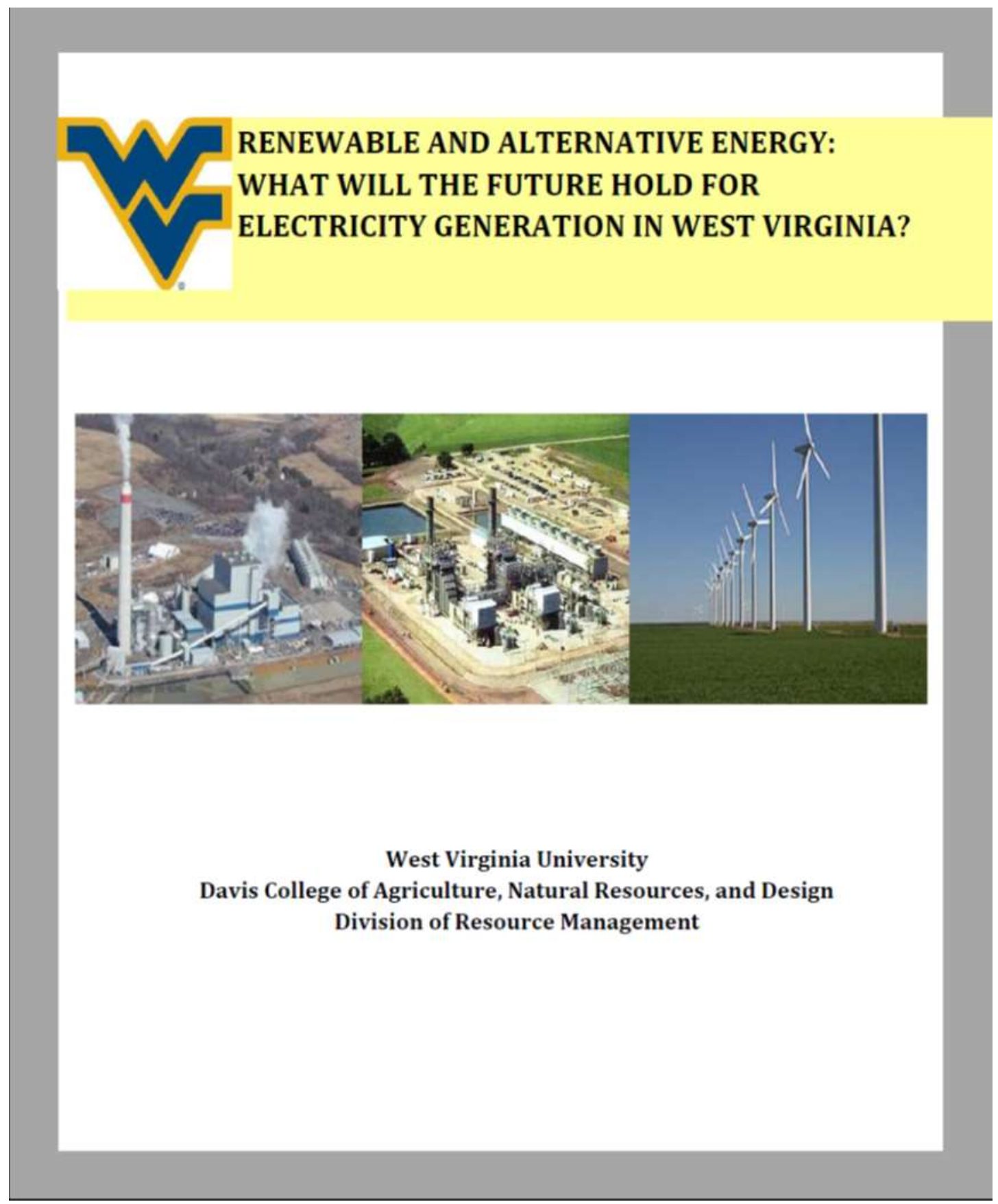




\section{Instructions:}

It should take about 15 to 20 minutes for you to complete this survey. When you finish, please return your completed survey in the envelope provided. The postage has been prepaid so there is no need to add postage

Your thoughts and opinions are important! So please consider filling out this survey. Your participation in this survey is completely voluntary.

If you have any questions or concerns regarding this survey, please contact Alan Collins at 304-293-5486 or by email at alan.collins@mail.wvu.edu

\section{Introduction:}

West Virginia law requires electric utilities to generate at least $10 \%$ of all electricity supplied to West Virginia residents from renewable and alternative energy sources by 2015. Renewable energy sources refer to all energy sources that are not depleted, including wind, solar and hydro power.

Alternative energy refers to all non-renewable energy sources that emit less air pollutants as compared to coal. In this study, we will consider wind as renewable and natural gas as an alternative energy source. They are readily available and technologically feasible in West Virginia.

In order to satisfy the requirements of the law by 2015, utilities will either have to build new renewable and/or alternative electricity generation facilities, expand existing facilities, or buy renewable electricity credits from out of state providers in order to meet the requirement of the law.

In the questions that follow (Q1 through Q13); we are going to ask about your experiences, preferences, and attitudes toward renewable and/or alternative sources of electricity generation. 


\section{Section A: General Information about You and Your Monthly Electricity Bill}

1) Is your household billed for electricity use by Mon Power?

\begin{tabular}{|l|c|}
\hline $\begin{array}{l}\text { YES- please continue answering questions in } \\
\text { this survey }\end{array}$ & $\square$ \\
\hline $\begin{array}{l}\text { NO- if you answer no, please skip to Section E } \\
\text { on page 18. Please return this survey after } \\
\text { answering the questions in section E. }\end{array}$ & $\square$ \\
\hline
\end{tabular}

2) Are you the person who makes payments for electricity bills in your household?

\begin{tabular}{|l|c|}
\hline YES & $\square$ \\
\hline NO & $\square$ \\
\hline
\end{tabular}

3) What is your average monthly electricity bill?

(Please check the most appropriate range).

$\$ 0-\$ 30$

$\$ 31-\$ 60$

$\$ 61-\$ 90$

$\$ 91-\$ 120$

$\$ 121-\$ 150$

$\$ 151-\$ 180$

Above $\$ 180$ 


\section{Section B: Attitudes towards the Environment and Electricity Generation}

4) By 2015, the Alternative and Renewable Energy Portfolio Standard will require 10\% of electricity supplied to West Virginia residents be generated from renewable or alternative sources of energy.

How familiar are you with this mandate? (Please check only one)

\begin{tabular}{|l|c|}
\hline Had not heard of it until this survey & $\square$ \\
\hline Slightly familiar & $\square$ \\
\hline Somewhat familiar & $\square$ \\
\hline Moderately familiar & $\square$ \\
\hline Very familiar & $\square$ \\
\hline
\end{tabular}

5) Do you support this mandate? (Please check only one)

\begin{tabular}{|l|c|}
\hline Yes, I support the mandate & $\square$ \\
\hline No, I do not support the mandate & $\square$ \\
\hline Not sure & $\square$ \\
\hline
\end{tabular}


6) There are a number of energy sources in West Virginia that can be used to generate electricity. We would like to know your level of familiarity on how each of these energy sources is converted into electricity.

How familiar are you about the following?

(Please check a single box for each row)

\begin{tabular}{|l|c|c|c|c|}
\hline Energy Source to Generate Electricity & High & Medium & Low & None \\
\hline $\begin{array}{l}\text { My level of familiarity with electricity } \\
\text { generated from burning of coal is... }\end{array}$ & $\square$ & $\square$ & $\square$ & $\square$ \\
\hline $\begin{array}{l}\text { My level of familiarity with electricity } \\
\text { generated from burning of natural gas } \\
\text { is.... }\end{array}$ & $\square$ & $\square$ & $\square$ & $\square$ \\
\hline $\begin{array}{l}\text { My level of familiarity with electricity } \\
\text { generated from wind turbines is..... }\end{array}$ & $\square$ & $\square$ & $\square$ & $\square$ \\
\hline
\end{tabular}


7) How often do you notice coal fired power plants at the following locations? (Please check a single box for each row)

\begin{tabular}{|l|c|c|c|}
\hline Location & Frequently & Sometimes & Never \\
\hline When I am at home & $\square$ & $\square$ & $\square$ \\
\hline When I am away from home & $\square$ & $\square$ & $\square$ \\
\hline
\end{tabular}

8) How often do you notice wind turbines at the following locations? (Please check a single box for each row)

\begin{tabular}{|l|c|c|c|}
\hline Location & Frequently & Sometimes & Never \\
\hline When I am at home & $\square$ & $\square$ & $\square$ \\
\hline When I am away from home & $\square$ & $\square$ & $\square$ \\
\hline
\end{tabular}


9) Electricity generation from wind turbines and burning of natural gas are judged to be the most likely sources of increased renewable and alternative electricity generation in West Virginia to meet the $10 \%$ mandate.

In your opinion, what strategies should Mon Power use to increase its renewable and alternative electricity generation capacity?

(Please check a single box for each row).

\begin{tabular}{|l|l|l|l|l|}
\hline $\begin{array}{l}\text { Strategies to meet the renewable } \\
\text { and/or alternative electricity goals }\end{array}$ & $\begin{array}{l}\text { High } \\
\text { Priority }\end{array}$ & $\begin{array}{l}\text { Low } \\
\text { Priority }\end{array}$ & $\begin{array}{l}\text { Do Not Use } \\
\text { this Option }\end{array}$ & $\begin{array}{l}\text { Don't } \\
\text { Know }\end{array}$ \\
\hline Renewable Electricity Goals & & & & \\
\hline $\begin{array}{l}\text { Expand existing wind farms by adding } \\
\text { more wind turbines }\end{array}$ & $\square$ & $\square$ & $\square$ & $\square$ \\
\hline Construct wind turbines on new sites & $\square$ & $\square$ & $\square$ & $\square$ \\
\hline$\underline{\text { Alternative Electricity Goals }}$ & & & & \\
\hline $\begin{array}{l}\text { Change existing coal power plants } \\
\text { into natural gas power plants }\end{array}$ & $\square$ & $\square$ & $\square$ & $\square$ \\
\hline $\begin{array}{l}\text { Build new natural gas fired power } \\
\text { plants }\end{array}$ & $\square$ & $\square$ & $\square$ & $\square$ \\
\hline
\end{tabular}

\section{Comments:}


Section C: Attitudes towards Coal, Natural Gas and Wind as Sources for Electricity Generation

10) At present, the most feasible and abundant energy sources for electricity generation in West Virginia are coal, natural gas, and wind.

What are your general attitudes toward electricity generation facilities that utilize these sources of energy? (Please check a single box for each row).

\begin{tabular}{|l|c|c|c|c|c|}
\hline Electricity Source & $\begin{array}{l}\text { Very } \\
\text { Negative }\end{array}$ & $\begin{array}{l}\text { Somewhat } \\
\text { Negative }\end{array}$ & Neutral & $\begin{array}{l}\text { Somewhat } \\
\text { Positive }\end{array}$ & $\begin{array}{l}\text { Very } \\
\text { Positive }\end{array}$ \\
\hline $\begin{array}{l}\text { What is your general } \\
\text { attitude towards coal- } \\
\text { fired power plants? }\end{array}$ & $\square$ & $\square$ & $\square$ & $\square$ & $\square$ \\
\hline $\begin{array}{l}\text { What is your general } \\
\text { attitude towards natural } \\
\text { gas power plants? }\end{array}$ & $\square$ & $\square$ & $\square$ & $\square$ & $\square$ \\
\hline $\begin{array}{l}\text { What is your general } \\
\text { attitude towards wind } \\
\text { turbines? }\end{array}$ & $\square$ & $\square$ & $\square$ & $\square$ & $\square$ \\
\hline
\end{tabular}

\section{Comments:}


11) There are many positive and negative impacts of electricity generation on the local community and environment.

In your opinion, which of the following electricity generation sources have the most positive impact on.....

(Please check a single box for each row).

\begin{tabular}{|l|c|c|c|}
\cline { 2 - 4 } \multicolumn{1}{c|}{} & \multicolumn{3}{c|}{ Most Positive Impact by: } \\
\hline Impact & Coal & $\begin{array}{c}\text { Natural } \\
\text { Gas }\end{array}$ & Wind \\
\hline Job creation & $\square$ & $\square$ & $\square$ \\
\hline Air quality & $\square$ & $\square$ & $\square$ \\
\hline View of the landscape & $\square$ & $\square$ & $\square$ \\
\hline Property values & $\square$ & $\square$ & $\square$ \\
\hline Climate change & $\square$ & $\square$ & $\square$ \\
\hline Wildlife (Birds \& Bats) & $\square$ & $\square$ & $\square$ \\
\hline Environment in general & $\square$ & $\square$ & $\square$ \\
\hline
\end{tabular}

\begin{tabular}{|c|}
\hline $\begin{array}{c}\text { Do Not Know } \\
\text { Enough to } \\
\text { Answer }\end{array}$ \\
\hline$\square$ \\
\hline$\square$ \\
\hline$\square$ \\
\hline$\square$ \\
\hline$\square$ \\
\hline$\square$ \\
\hline$\square$ \\
\hline
\end{tabular}

\section{Comments}


12) There are many positive and negative impacts of electricity generation on the local community and environment.

In your opinion, which of the following electricity generation sources have the most negative impact on.....

(Please check a single box for each row).

\begin{tabular}{|l|c|c|c|}
\cline { 2 - 4 } \multicolumn{1}{c|}{} & \multicolumn{3}{c|}{ Most Negative Impact by: } \\
\hline$\underline{\text { Impact }}$ & Coal & $\begin{array}{c}\text { Natural } \\
\text { Gas }\end{array}$ & Wind \\
\hline Job creation & $\square$ & $\square$ & $\square$ \\
\hline Air quality & $\square$ & $\square$ & $\square$ \\
\hline View of the landscape & $\square$ & $\square$ & $\square$ \\
\hline Property values & $\square$ & $\square$ & $\square$ \\
\hline Climate change & $\square$ & $\square$ & $\square$ \\
\hline Wildlife (Birds \& Bats) & $\square$ & $\square$ & $\square$ \\
\hline Environment in general & $\square$ & $\square$ & $\square$ \\
\hline
\end{tabular}

\begin{tabular}{|c|}
\hline $\begin{array}{c}\text { Do Not Know } \\
\text { Enough to } \\
\text { Answer }\end{array}$ \\
\hline$\square$ \\
\hline$\square$ \\
\hline$\square$ \\
\hline$\square$ \\
\hline$\square$ \\
\hline$\square$ \\
\hline$\square$ \\
\hline
\end{tabular}

\section{Comments}


13) In order to understand your opinions and concerns about electricity generation, you are presented with a series of statements below. Please indicate your strength of agreement or disagreement with each statement by marking the box that best represents your opinion.

(Please check a single box for each row).

\begin{tabular}{|c|c|c|c|c|c|}
\hline$\underline{\text { Items }}$ & $\begin{array}{l}\text { Strongly } \\
\text { Disagree }\end{array}$ & $\begin{array}{l}\text { Somewhat } \\
\text { Disagree }\end{array}$ & Neutral & $\begin{array}{l}\begin{array}{l}\text { Somewhat } \\
\text { Agree }\end{array} \\
\end{array}$ & $\begin{array}{l}\begin{array}{l}\text { Strongly } \\
\text { Agree }\end{array} \\
\end{array}$ \\
\hline $\begin{array}{l}\text { For electricity, I am mainly } \\
\text { concerned about how much I } \\
\text { pay on my electricity bill. }\end{array}$ & $\square$ & $\square$ & $\square$ & $\square$ & $\square$ \\
\hline $\begin{array}{l}\text { I am concerned about pollution } \\
\text { created by electricity } \\
\text { generation. }\end{array}$ & $\square$ & $\square$ & $\square$ & $\square$ & $\square$ \\
\hline $\begin{array}{l}\text { It is important to invest in } \\
\text { power plants that generate the } \\
\text { least amount of pollution. }\end{array}$ & $\square$ & $\square$ & $\square$ & $\square$ & $\square$ \\
\hline $\begin{array}{l}\text { State and federal governments } \\
\text { have adequate measures in } \\
\text { place to protect the } \\
\text { environment from pollution } \\
\text { generated by power plants. }\end{array}$ & $\square$ & $\square$ & $\square$ & $\square$ & $\square$ \\
\hline $\begin{array}{l}\text { Each consumer should be able } \\
\text { to choose the electricity } \\
\text { generation source that he or she } \\
\text { prefers. }\end{array}$ & $\square$ & $\square$ & $\square$ & $\square$ & $\square$ \\
\hline $\begin{array}{l}\text { I would be willing to pay more } \\
\text { for electricity that is generated } \\
\text { with less pollution than current } \\
\text { energy sources (mainly coal). }\end{array}$ & $\square$ & $\square$ & $\square$ & $\square$ & $\square$ \\
\hline
\end{tabular}


You are going to be asked to choose between electricity choice options that meet the requirements of the West Virginia Renewable and Alternative Portfolio standard by. These choices will require you to make trade-offs between energy source (wind or natural gas), location of where the electricity supplied to your residence is generated (near, moderate or far distance from your home) and cost of generating renewable and/or alternative electricity (expressed as an increase in your monthly electricity bill).

The choice options have been randomly assigned. Please treat these choices as if you were actually being offered the opportunity to choose your source of electricity and where it is generated. I realize that these option(s) are not available in West Virginia at the current time. However, your choices are important in shaping future policies on how the general public views renewable and alternative sources of electricity generation in West Virginia.

It is important for you to answer questions 14, 15, and 16 independent of one another. For example, please do not let the options presented to you in question 14, influence your choice in questions 15 and 16. For each question, choose the option (Wind Power or Natural Gas Power) that best reflects your preferences.

A detailed explanation of all categories of impacts from wind farms and natural gas power plants are presented in the Appendix on the last page (page 23) of this survey. 


\section{Risks and Benefits by Energy Source}

Before you choose, a brief explanation of important benefits and risks associated with each of the electricity generation sources is presented below.

\begin{tabular}{|c|c|c|}
\hline $\begin{array}{c}\text { Electricity } \\
\text { Generation } \\
\text { Source } \\
\end{array}$ & $\begin{array}{l}\text { Cost Impacts (more } \\
\$ \text { means higher cost) }\end{array}$ & Environmental Impacts \\
\hline Coal & Lowest electricity rates. & $\begin{array}{l}\text { High pollution } \\
\text { Waste disposal of ash } \\
\text { Mining disturbance }\end{array}$ \\
\hline Natural Gas & $\begin{array}{l}\text { Slightly higher } \\
\text { electricity rates }\end{array}$ & Low air pollution \\
\hline Wind & Highest electricity rates & $\begin{array}{l}\text { Zero air pollution. } \\
\text { Alters view } \\
\text { Bat kills }\end{array}$ \\
\hline
\end{tabular}


Continue on to answer question 14,15 , and 16 on the next page $\rightarrow \rightarrow \rightarrow$

A detailed explanation of all categories of impacts from wind farms and natural gas power plants are presented in the Appendix on the last page (page 23) of this survey. 
14) Currently, $100 \%$ of your electricity comes from coal energy. Assume you have the opportunity to choose a renewable or alternative electricity source and where it is generated (location of the facility). This energy source will fulfill $10 \%$ of the electricity supplied to your home. Which of the following options will you choose?

\begin{tabular}{|c|c|c|}
\hline Energy Source & Wind & Natural Gas \\
\hline $\begin{array}{l}\text { Location of power } \\
\text { plant relative to your } \\
\text { residence } \\
\text { (Refer to the } \\
\text { Appendix for } \\
\text { comparisons of near, } \\
\text { moderate and far } \\
\text { away) }\end{array}$ & $\begin{array}{l}\quad \text { Near } \\
\quad \text { Distance: Within } 2 \text { miles } \\
\text { Visual: High visibility of } \\
\text { turbines } \\
\text { Noise: Disturbance can occur } \\
\text { Property Value: Moderate } \\
\text { decline in value (1\%) within } \\
\text { 0.5 miles } \\
\text { Pollution (Environment and } \\
\text { health): None }\end{array}$ & $\begin{array}{l}\quad \text { Near } \\
\quad \text { Distance: within } 2 \text { miles } \\
\text { Visual: High visibility of Stack and } \\
\text { Smoke } \\
\text { Noise: None } \\
\text { Property Value: Moderate } \\
\text { decline(1-2\%) within a mile } \\
\text { Pollution (Environment and } \\
\text { health): High health effects: } 5 \\
\text { times greater than residential } \\
\text { locations that are far away }\end{array}$ \\
\hline $\begin{array}{l}\text { Cost (An increase in } \\
\text { your current monthly } \\
\text { electricity bill) }\end{array}$ & $\$ 1$ & $\$ 5$ \\
\hline
\end{tabular}

I will choose... $\square$ Wind $\square$ Natural Gas

(Please check only one)

14a) On a scale of 1 to 10 , how certain are you about the above choice if you actually had to make this decision?

\begin{tabular}{|c|c|c|c|c|c|c|c|c|c|c|}
\hline Scale & 1 & 2 & 3 & 4 & 5 & 6 & 7 & 8 & 9 & 10 \\
\hline & $\begin{array}{c}\text { Very } \\
\text { Uncertain }\end{array}$ & $\begin{array}{c}\text { Not } \\
\text { Completely } \\
\text { Certain }\end{array}$ & & & & $\begin{array}{c}\text { Fairly } \\
\text { Certain }\end{array}$ & & & $\begin{array}{c}\text { Very } \\
\text { Certain }\end{array}$ \\
\hline Certainty & $\square$ & $\square$ & $\square$ & $\square$ & $\square$ & $\square$ & $\square$ & $\square$ & $\square$ & $\square$ \\
\hline
\end{tabular}


15) Currently, $100 \%$ of your electricity comes from coal energy. Assume you have the opportunity to choose a renewable or alternative electricity source and where it is generated (location of the facility). This energy source will fulfill $10 \%$ of the electricity supplied to your home. Which of the following options will you choose?

\begin{tabular}{|c|c|c|}
\hline Energy Source & Wind & Natural Gas \\
\hline $\begin{array}{c}\text { Location of power } \\
\text { plant relative to your } \\
\text { residence } \\
\text { (Refer to the } \\
\text { Appendix for } \\
\text { comparisons of near, } \\
\text { moderate and far } \\
\text { away) }\end{array}$ & $\begin{array}{l}\quad \text { Far Away } \\
\text { Distance: At least } 19 \text { miles or } \\
\text { greater. } \\
\text { Visual: Turbines are too far } \\
\text { away to see } \\
\text { Noise: None } \\
\text { Property Value: None } \\
\text { Pollution (Environment and } \\
\text { health): None }\end{array}$ & $\begin{array}{l}\text { Moderate Distance } \\
\text { Distance: Between } 2 \text { to } 19 \text { miles } \\
\text { Visual: Medium visibility of stack } \\
\text { and smoke } \\
\text { Noise: None } \\
\text { Property Value: None } \\
\text { Pollution (Environment and } \\
\text { health): High health effects: } 5 \\
\text { times greater than residential } \\
\text { locations that are far away }\end{array}$ \\
\hline $\begin{array}{l}\text { Cost (An increase in } \\
\text { your current monthly } \\
\text { electricity bill) }\end{array}$ & $\$ 15$ & $\$ 15$ \\
\hline
\end{tabular}

I will choose... $\quad \square$ Wind $\square$ Natural Gas

(Please check only one)

15a) On a scale of 1 to 10 , how certain are you about the above choice if you actually had to make this decision?

\begin{tabular}{|c|c|c|c|c|c|c|c|c|c|c|}
\hline Scale & 1 & 2 & 3 & 4 & 5 & 6 & 7 & 8 & 9 & 10 \\
\hline & $\begin{array}{c}\text { Very } \\
\text { Uncertain }\end{array}$ & & $\begin{array}{c}\text { Not } \\
\text { Completely } \\
\text { Certain }\end{array}$ & & & & $\begin{array}{c}\text { Fairly } \\
\text { Certain }\end{array}$ & & & $\begin{array}{c}\text { Very } \\
\text { Certain }\end{array}$ \\
\hline Certainty & $\square$ & $\square$ & $\square$ & $\square$ & $\square$ & $\square$ & $\square$ & $\square$ & $\square$ & $\square$ \\
\hline
\end{tabular}


16) Currently, $100 \%$ of your electricity comes from coal energy. Assume you have the opportunity to choose a renewable or alternative electricity source and where it is generated (location of the facility). This energy source will fulfill $10 \%$ of the electricity supplied to your home. Which of the following options will you choose?

\begin{tabular}{|c|c|c|}
\hline Energy Source & Wind & Natural Gas \\
\hline $\begin{array}{l}\text { Location of power } \\
\text { plant relative to your } \\
\text { residence } \\
\text { (Refer to the } \\
\text { Appendix for } \\
\text { comparisons of near, } \\
\text { moderate and far } \\
\text { away) }\end{array}$ & $\begin{array}{l}\quad \text { Near } \\
\quad \text { Distance: Within } 2 \text { miles } \\
\text { Visual: High visibility of turbines } \\
\text { Noise: Disturbance can occur } \\
\text { Property Value: Moderate } \\
\text { decline in value (1\%) within } 0.5 \\
\text { miles } \\
\text { Pollution (Environment and } \\
\text { health): None }\end{array}$ & $\begin{array}{l}\quad \text { Far Away } \\
\text { Distance: At least } 19 \text { miles or } \\
\text { greater. } \\
\text { Visual: Minimal visibility of smoke if } \\
\text { at all visible. Stack may be too far } \\
\text { away to see } \\
\text { Noise: None } \\
\text { Property Value: None } \\
\text { Pollution (Environment and } \\
\text { health): Low health effects } \\
\text { compared to locations that are at } \\
\text { near and moderate distances }\end{array}$ \\
\hline $\begin{array}{l}\text { Cost (An increase in } \\
\text { your current monthly } \\
\text { electricity bill) }\end{array}$ & $\$ 5$ & $\$ 10$ \\
\hline
\end{tabular}

I will choose... $\square$ Wind $\square$ Natural Gas

(Please check only one)

16a) On a scale of 1 to 10 , how certain are you about the above choice if you actually had to make this decision?

\begin{tabular}{|c|c|c|c|c|c|c|c|c|c|c|}
\hline Scale & 1 & 2 & 3 & 4 & 5 & 6 & 7 & 8 & 9 & 10 \\
\hline & $\begin{array}{c}\text { Very } \\
\text { Uncertain }\end{array}$ & & $\begin{array}{c}\text { Not } \\
\text { Completely } \\
\text { Certain }\end{array}$ & & & & $\begin{array}{c}\text { Fairly } \\
\text { Certain }\end{array}$ & & & $\begin{array}{c}\text { Very } \\
\text { Certain }\end{array}$ \\
\hline Certainty & $\square$ & $\square$ & $\square$ & $\square$ & $\square$ & $\square$ & $\square$ & $\square$ & $\square$ & $\square$ \\
\hline
\end{tabular}


17) Investments in renewable and alternative electricity generation facilities have many economic benefits. In your opinion, where are these economic benefits important? (Please check all that apply)

\begin{tabular}{|l|c|}
\hline $\begin{array}{l}\text { Within the immediate community where the } \\
\text { facility is located }\end{array}$ & $\square$ \\
\hline $\begin{array}{l}\text { Anywhere within the county where the facility is } \\
\text { located }\end{array}$ & $\square$ \\
\hline Within the state of West Virginia & $\square$ \\
\hline Nationally & $\square$ \\
\hline
\end{tabular}


Section E: Finally, a Few Questions about Yourself to Help Us Interpret the Results of the Survey

18) Are you male or female?

Male

Female $\square$

19) What year were you born?

19

20) How long have you lived in West Virginia? (Please check only one)

Less than a year $\square$

1 to 5 years

5 to 10 years $\square$

10 to 20 years $\square$

More than 20 years $\square$

All my life 
21) What is the highest level of education that you have completed?

(Please check one)

Elementary or Junior High School $\square$

High school graduate/GED $\square$

Associate degree/Trade School $\square$

College degree $\square$

Graduate degree

22) What is your current housing status?

Homeowner $\square$

Renter $\square$

Other $\square$ please explain: 
23) Are you currently or have you ever been a member of an environmental organization (eg. Sierra Club, Nature Conservancy, Watershed Association, etc)?

Yes $\square$

No

24) Which category best describes your household gross income (before taxes) in 2012?

Less than $\$ 10,000 \square$

$\$ 10,000-\$ 14,999$

$\$ 15,000-\$ 24,999 \square$

$\$ 25,000-\$ 34,999 \square$

$\$ 35,000-\$ 49,999 \square$

$\$ 50,000-\$ 74,999 \square$

$\$ 75,000-\$ 99,999$

$\$ 100,000-\$ 149,999$

\$150,000-\$199,999

$\$ 200,000$ and above $\square$ 
25) Lastly, do you have comments about this survey or issues related to this survey that you would like to share?

(Please use the space provided below or skip to the end of the survey if you have no comments) 
Your time is greatly appreciated. Please return the survey in the enclosed envelope. If the envelope was misplaced, return it to the address below. Thank you!

\author{
Alan Collins \\ Division of Resource Management \\ Ag. Sci. Bldg. Room 2026 \\ P.O. Box 6108 \\ West Virginia University \\ Morgantown, WV 26506
}

If you would like to be sent a written report of the results, please fill in your address below: 
APPENDIX

Impacts of Wind and Natural Gas Power Based upon Location

\begin{tabular}{|c|c|c|}
\hline \multirow[b]{2}{*}{ Location } & \multicolumn{2}{|c|}{ IMPACTS } \\
\hline & $\begin{array}{l}\text { Wind Turbine Facility (Wind } \\
\text { Power) } 150 \text { Megawatts }\end{array}$ & $\begin{array}{l}\text { Natural Gas Power Plant ( } 210 \\
\text { Megawatts) }\end{array}$ \\
\hline $\begin{array}{l}\text { Near Your } \\
\text { Residence }\end{array}$ & $\begin{array}{l}\text { Distance: within } 2 \text { miles } \\
\text { Visual: High visibility of turbines } \\
\text { Noise: Disturbance can occur } \\
\text { Property Value: Moderate decline in } \\
\text { value (1\%) within } 0.5 \text { miles } \\
\text { Pollution (Environment and } \\
\text { health): None }\end{array}$ & $\begin{array}{l}\text { Distance: within } 2 \text { miles } \\
\text { Visual: High visibility of Stack and } \\
\text { Smoke } \\
\text { Noise: None } \\
\text { Property Value: Moderate decline } \\
(1-2 \%) \text { within a mile } \\
\text { Pollution (Environment and health): } \\
\text { High health effects: } 5 \text { times greater } \\
\text { than residential locations that are far } \\
\text { away }\end{array}$ \\
\hline $\begin{array}{l}\text { Moderate } \\
\text { Distance } \\
\text { From } \\
\text { Your } \\
\text { Residence }\end{array}$ & $\begin{array}{l}\text { Distance: Between } 2 \text { to } 19 \text { miles } \\
\text { Visual: Medium visibility of turbines } \\
\text { Noise: None } \\
\text { Property Value: None } \\
\text { Pollution (Environment and } \\
\text { health): None }\end{array}$ & $\begin{array}{l}\text { Distance: Between } 2 \text { to } 19 \text { miles } \\
\text { Visual: Medium visibility of stack and } \\
\text { smoke } \\
\text { Noise: None } \\
\text { Property Value: None } \\
\text { Pollution (Environment and health): } \\
\text { High health effects: } 5 \text { times greater } \\
\text { than residential locations that are far } \\
\text { away }\end{array}$ \\
\hline $\begin{array}{l}\text { Far Away } \\
\text { From } \\
\text { Your } \\
\text { Residence }\end{array}$ & $\begin{array}{l}\text { Distance: At least } 19 \text { miles or } \\
\text { greater. } \\
\text { Visual: Turbines are too far away to } \\
\text { see } \\
\text { Noise: None } \\
\text { Property Value: None } \\
\text { Pollution (Environment and } \\
\text { health): None }\end{array}$ & $\begin{array}{l}\text { Distance: At least } 19 \text { miles or greater. } \\
\text { Visual: Minimal visibility of smoke if at } \\
\text { all visible. Stack may be too far away to } \\
\text { see } \\
\text { Noise: None } \\
\text { Property Value: None } \\
\text { Pollution (Environment and health): } \\
\text { Low health effects compared to } \\
\text { locations that are at near and } \\
\text { moderate distances }\end{array}$ \\
\hline
\end{tabular}




\section{APPENDIX II: Map of West Virginia identifying Monongalia County and Grant County.}

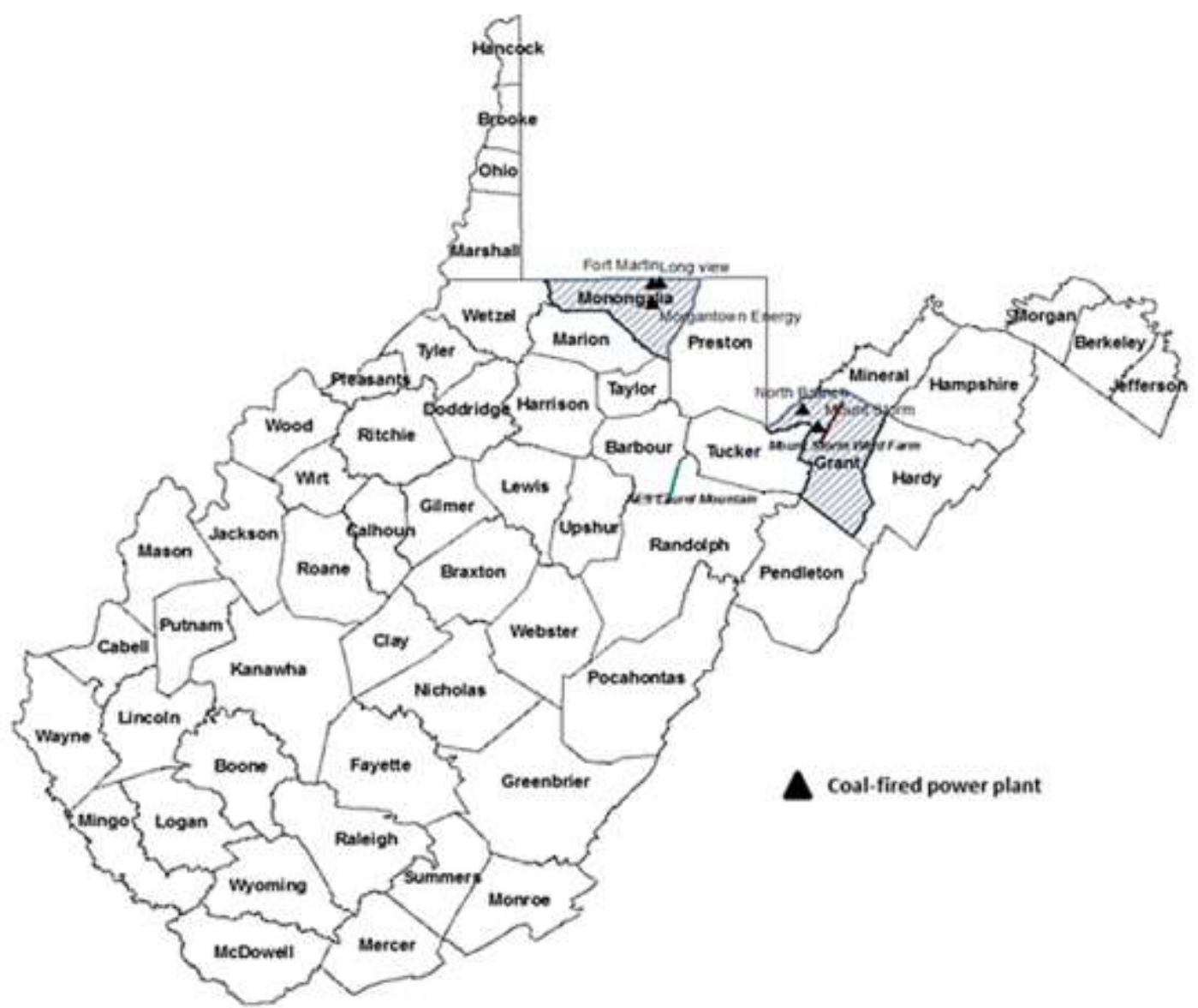

Map of West Virginia: Monongalia County and Grant County Shaded 
APPENDIX III: Multinomial logit models of Grant County and Monongalia County sampled populations.

\begin{tabular}{|l|c|c|}
\hline \multicolumn{1}{|c|}{ VARIABLE } & $\begin{array}{c}\text { MONONGALIA } \\
\text { COUNTY } \\
\text { SAMPLE }\end{array}$ & $\begin{array}{c}\text { GRANT } \\
\text { COUNTY } \\
\text { SAMPLE }\end{array}$ \\
\hline \hline WIND_MODERATE & $0.253^{* *}$ & -0.132 \\
\hline WIND_FAR & $0.312^{* *}$ & $0.282^{* * *}$ \\
\hline NGAS_MODERATE & $-0.212^{*}$ & $-0.193^{* *}$ \\
\hline NGAS_FAR & $0.670^{* * *}$ & $0.438^{* * *}$ \\
\hline \hline ASC_WIND & $2.708^{* * *}$ & $1.341^{* * *}$ \\
\hline FEES & $-0.090^{* * *}$ & $-0.096^{* * *}$ \\
\hline AVERAGE BILL & $-0.003^{*}$ & -0.001 \\
\hline SUPPORT_ARPS & $0.626^{* * *}$ & 0.161 \\
\hline SEECOAL_H & -0.249 & -0.262 \\
\hline SEEWIND_H & 0.171 & $-0.333^{*}$ \\
\hline CONCERN_BILL & $-0.411^{*}$ & 0.131 \\
\hline INVEST_LESS POLLUTION & 0.332 & $0.552^{* * *}$ \\
\hline NEG ATTITUDE COAL & $0.733^{* *}$ & $0.763^{* * *}$ \\
\hline NEG IMPACTS NGAS & 0.009 & 0.004 \\
\hline NEG IMPACTS WIND & $-0.041^{* * *}$ & $-0.024^{* * *}$ \\
\hline GENDER & 0.105 & 0.195 \\
\hline AGE & $-0.016^{* *}$ & -0.005 \\
\hline ENV AFFILIATION & 0.336 & $-1.198^{* * *}$ \\
\hline 4 YEAR COLLEGE & -0.062 & -0.254 \\
\hline \hline NUMBER OF OBSERVATIONS & 927 & 1150 \\
\hline LOG LIKELIHOOD & -430.95 & -627.24 \\
\hline \hline
\end{tabular}

$* * * 1 \%$ significance, $* * 5 \%$ significance, $* 10 \%$ significance 
APPENDIX IV: Mixed logit Model for the Pooled Population (Monongalia County and Grant County).

\begin{tabular}{|c|c|}
\hline VARIABLE & POOLED POPULATION \\
\hline \multicolumn{2}{|c|}{ RANDOM PARAMETERS (MEAN) } \\
\hline WIND_MODERATE & -0.042 \\
\hline WIND_FAR & $0.393 * * *$ \\
\hline NGAS_MODERATE & $-0.228 * *$ \\
\hline NGAS_FAR & $0.631^{* * *}$ \\
\hline \multicolumn{2}{|c|}{ NON RANDOM PARAMETERS (MEAN) } \\
\hline ASC_WIND & $2.166^{* * *}$ \\
\hline FEES & $-0.112 * * *$ \\
\hline AVERAGE BILL & -0.002 \\
\hline SUPPORT_ARPS & $0.462 * *$ \\
\hline SEECOAL_H & $-0.354 * *$ \\
\hline SEEWIND_H & -0.035 \\
\hline CONCERN_BILL & -0.146 \\
\hline INVEST_LESSS POLLUTION & $0.594 * * *$ \\
\hline NEG ATTITUDE COAL & $0.971 * * *$ \\
\hline NEG IMPACTS NGAS & $0.010 * *$ \\
\hline NEG IMPACTS WIND & $-0.036 * * *$ \\
\hline GENDER & 0.205 \\
\hline AGE & $-0.108 * *$ \\
\hline ENV AFFILIATION & 0.047 \\
\hline 4 YEAR COLLEGE & -0.223 \\
\hline \multicolumn{2}{|c|}{ STANDARD DEVATIONS OF RANDOM PARAMETER } \\
\hline WIND_MODERATE & 0.076 \\
\hline WIND_FAR & $1.145^{* *}$ \\
\hline NGAS_MODERATE & 0.445 \\
\hline NGAS_FAR & 0.748 \\
\hline NUMBER OF OBSERVATIONS & 2077 \\
\hline LOG LIKELIHOOD & -1085.70 \\
\hline McFADDEN PSEUDO R-SQUARE & 0.25 \\
\hline
\end{tabular}

$* * * 1 \%$ Significance, $* * 5 \%$ Significance, $* 10 \%$ Significance 
APPENDIX V: Mixed logit Model of Respondents with Wind Turbines within Sight from Residence vs. Wind Turbines not within Sight from Residence (Grant County).

\begin{tabular}{|c|c|c|}
\hline VARIABLE & $\begin{array}{c}\text { SEE WIND } \\
\text { TURBINES FROM } \\
\text { RESIDENCE }\end{array}$ & $\begin{array}{l}\text { DO NOT SEE } \\
\text { WIND TURBINES } \\
\text { FROM } \\
\text { RESIDENCE }\end{array}$ \\
\hline \multicolumn{3}{|c|}{ RANDOM PARAMETERS (MEAN) } \\
\hline WIND_MODERATE & -0.376 & 0.176 \\
\hline WIND_FAR & $0.570^{*}$ & 0.355 \\
\hline NGAS_MODERATE & -0.296 & 0.220 \\
\hline NGAS_FAR & $0.800 * *$ & 0.799 \\
\hline \multicolumn{3}{|c|}{ NON RANDOM PARAMETERS (MEAN) } \\
\hline ASC_WIND & 1.767 & 5.73 \\
\hline FEES & $-0.191 * *$ & -0.225 \\
\hline AVERAGE BILL & -0.001 & -0.003 \\
\hline SUPPORT_ARPS & 0.367 & -0.752 \\
\hline SEECOAL_H & -.0309 & -2.228 \\
\hline CONCERN_BILL & 0.329 & -1.296 \\
\hline INVEST_LESS POLLUTION & 0.557 & 2.502 \\
\hline NEG ATTITUDE COAL & 1.032 & $3.327^{* *}$ \\
\hline NEG IMPACTS NGAS & 0.001 & 0.012 \\
\hline NEG IMPACTS WIND & $-0.044 * * *$ & -0.050 \\
\hline GENDER & 0.502 & 0.537 \\
\hline AGE & -0.005 & -0.031 \\
\hline ENV AFFILIATION & -1.060 & -4.808 \\
\hline 4 YEAR COLLEGE & -0.451 & -1.460 \\
\hline \multicolumn{3}{|c|}{ STANDARD DEVATIONS OF RANDOM PARAMETER } \\
\hline WIND_MODERATE & 1.931 & 0.476 \\
\hline WIND_FAR & 0.067 & 0.343 \\
\hline NGAS_MODERATE & $2.616^{* *}$ & 1.041 \\
\hline NGAS_FAR & 0.028 & 0.299 \\
\hline NUMBER OF OBSERVATIONS & 827 & 323 \\
\hline LOG LIKELIHOOD & -463.74 & -151.18 \\
\hline MCFADDEN PSEUDO R-SQUARE & 0.19 & 0.32 \\
\hline
\end{tabular}




\section{APPENDIX VI: Summary Statistics of Choices vs. Certainty Levels.}

\begin{tabular}{|l|c|c||c|c|}
\cline { 2 - 5 } \multicolumn{1}{c|}{} & \multicolumn{2}{c||}{ Monongalia County } & \multicolumn{2}{c|}{ Grant County } \\
\cline { 2 - 5 } & $\begin{array}{c}\text { Number of } \\
\text { Observations } \\
\text { (Choice sets) }\end{array}$ & $\begin{array}{c}\text { Percentage } \\
\text { (\%) }\end{array}$ & $\begin{array}{c}\text { Number of } \\
\text { Observations } \\
\text { (Choice sets) }\end{array}$ & $\begin{array}{c}\text { Percentage } \\
\text { (\%) }\end{array}$ \\
\hline $\begin{array}{l}\text { Choice situations with certainty } \\
\text { levels less than 7 (Below fairly } \\
\text { certain to very uncertain) }\end{array}$ & 232 & 25.1 & 361 & 31.5 \\
\hline $\begin{array}{l}\text { Choice situations with certainty } \\
\text { levels equal to or more than 7 } \\
\text { (fairly certain to very certain) }\end{array}$ & 691 & 74.9 & 786 & 68.5 \\
\hline Total & $923^{\mathrm{a}}$ & 100 & $1147^{\mathrm{b}}$ & 100 \\
\hline
\end{tabular}




\section{APPENDIX VII: Multinomial Logit Models of observations Separated by Certainty Levels of Choices Made.}

Multinomial logit model of Observations separated by Certainty levels (Certain vs. Uncertain Choices) - Monongalia County.

\begin{tabular}{|l|c|c|c|}
\hline \multicolumn{1}{|c|}{ VARIABLE } & $\begin{array}{c}\text { POOLED } \\
\text { MONONGALIA } \\
\text { COUNTY } \\
\text { SAMPLE }\end{array}$ & $\begin{array}{c}\text { CERTAIN } \\
\text { CHOICES }\end{array}$ & $\begin{array}{c}\text { UNCERTAIN } \\
\text { CHOICES }\end{array}$ \\
\hline WIND_MODERATE & $0.253^{* *}$ & 0.214 & 0.358 \\
\hline WIND_FAR & $0.312^{* *}$ & $0.379^{* *}$ & 0.219 \\
\hline NGAS_MODERATE & $-0.212^{*}$ & -0.202 & -0.253 \\
\hline NGAS_FAR & $0.670^{* * *}$ & $0.614^{* * *}$ & $0.885^{* * *}$ \\
\hline \hline ASC_WIND & $2.708^{* * *}$ & $3.422^{* * *}$ & $2.872^{* * *}$ \\
\hline FEES & $-0.090^{* * *}$ & $-0.106^{* * *}$ & $-0.072^{* * *}$ \\
\hline AVERAGE BILL & $-0.003^{*}$ & -0.003 & -0.004 \\
\hline SUPPORT_ARPS & $0.626^{* * *}$ & $0.770^{* * *}$ & -0.231 \\
\hline SEECOAL_H & -0.249 & -0.325 & -0.277 \\
\hline SEEWIND_H & 0.171 & 0.082 & 0.431 \\
\hline CONCERN_BILL & $-0.411^{*}$ & $-0.487^{*}$ & -0.612 \\
\hline INVEST_LESS POLLUTION & 0.332 & 0.241 & 0.264 \\
\hline NEG ATTITUDE COAL & $0.733^{* *}$ & $0.905^{* * *}$ & 0.267 \\
\hline NEG IMPACTS NGAS & 0.009 & 0.003 & $0.034^{* *}$ \\
\hline NEG IMPACTS WIND & $-0.041^{* * *}$ & $-0.051^{* * *}$ & $-0.021^{* * *}$ \\
\hline GENDER & 0.105 & 0.028 & 0.320 \\
\hline AGE & $-0.016^{* *}$ & $-0.015^{*}$ & $-0.027^{* *}$ \\
\hline ENV AFFILIATION & 0.336 & 0.009 & $1.234^{* *}$ \\
\hline 4 YEAR COLLGE & -0.062 & -0.207 & -0.026 \\
\hline NUMBER OF OBSERVATIONS & 927 & 691 & 236 \\
\hline LOG LIKELIHOOD & -430.95 & -286.73 & -125.77 \\
\hline \hline
\end{tabular}

$* * * 1 \%$ significance, $* * 5 \%$ significance, $* 10 \%$ significance 
Multinomial logit model of Observations separated by Certainty levels (Certain vs. Uncertain Choices) - Grant County.

\begin{tabular}{|l|c|c|c|}
\hline \multicolumn{1}{|c|}{ VARIABLE } & $\begin{array}{c}\text { POOLED } \\
\text { GRANT COUNTY } \\
\text { SAMPLE }\end{array}$ & $\begin{array}{c}\text { CERTAIN } \\
\text { CHOICES }\end{array}$ & $\begin{array}{c}\text { UNCERTAIN } \\
\text { CHOICES }\end{array}$ \\
\hline \hline WIND_MODERATE & -0.132 & -0.163 & -0.097 \\
\hline WIND_FAR & $0.282^{* * *}$ & $0.258^{* *}$ & $0.347^{*}$ \\
\hline NGAS_MODERATE & $-0.193^{* *}$ & $-0.198^{*}$ & -0.306 \\
\hline NGAS_FAR & $0.438^{* * *}$ & $0.383^{* * *}$ & $0.610^{* * *}$ \\
\hline \hline ASC_WIND & $1.341^{* * *}$ & $1.647^{* * *}$ & 0.114 \\
\hline FEES & $-0.096^{* * *}$ & $-0.108^{* * *}$ & $-0.073^{* * *}$ \\
\hline AVERAGE BILL & -0.001 & -0.003 & 0.003 \\
\hline SUPPORT_ARPS & 0.161 & -0.003 & 0.470 \\
\hline SEECOAL_H & -0.262 & -0.087 & $-1.005^{* * *}$ \\
\hline SEEWIND_H & $-0.333^{*}$ & $-0.584^{* *}$ & 0.449 \\
\hline CONCERN_BILL & 0.131 & 0.408 & -0.164 \\
\hline INVEST_LESS POLLUTION & $0.552^{* * *}$ & $0.615^{* * *}$ & $0.539^{*}$ \\
\hline NEG ATTITUDE COAL & $0.763^{* * *}$ & $0.719^{* *}$ & $0.799^{*}$ \\
\hline NEG IMPACTS NGAS & 0.004 & 0.005 & -0.002 \\
\hline NEG IMPACTS WIND & $-0.024^{* * *}$ & $-0.029^{* * *}$ & $-0.013^{* *}$ \\
\hline GENDER & 0.195 & 0.104 & 0.328 \\
\hline AGE & -0.005 & -0.009 & 0.010 \\
\hline ENV AFFILIATION & $-1.198^{* * *}$ & $-1.176^{* *}$ & -0.522 \\
\hline 4 YEAR COLLEGE & -0.254 & -0.097 & -0.393 \\
\hline NUMBER OF OBSERVATIONS & 1150 & 786 & 364 \\
\hline LOG LIKELIHOOD & -627.24 & -418.07 & -188.32 \\
\hline \hline
\end{tabular}

$* * * 1 \%$ significance, $* * 5 \%$ significance, $* 10 \%$ significance 


\section{APPENDIX VIII: Willingness to Pay Estimations for Observations Separated by Certainty Levels of Choices Made.}

Willingness to pay for proximity as an attribute of electricity generation source (Certain and uncertain choice observations):- Monongalia County.

\begin{tabular}{|c|c|c|c|}
\hline & & & \multirow{3}{*}{$\begin{array}{c}\text { Uncertain Choices } \\
\text { Weighted Mean WTP per } \\
\text { month (95\% Confidence } \\
\text { Interval) }{ }^{\mathrm{a}}\end{array}$} \\
\hline & \multirow{2}{*}{$\begin{array}{c}\text { Certain Choices } \\
\text { Weighted Mean WTP per } \\
\text { month (95\% Confidence } \\
\text { Interval) }{ }^{\mathrm{a}}\end{array}$} & \\
\hline Energy Source & $\begin{array}{c}\text { Location of Facility } \\
\text { Relative to Respondents' } \\
\text { Residence ( } 95 \% \\
\text { Confidence Interval) } \\
\end{array}$ & & \\
\hline \multirow{2}{*}{ Wind } & Moderate Distance & $\begin{array}{c}\$ 9.36 \\
(5.94-12.75)\end{array}$ & $\begin{array}{c}\$ 15.40 \\
(5.31-25.49)\end{array}$ \\
\hline & Far Away Distance & $\begin{array}{c}\$ 10.62 \\
(6.85-14.38)\end{array}$ & $\begin{array}{c}\$ 13.83 \\
(4.45-23.21)\end{array}$ \\
\hline \multirow{2}{*}{ Natural Gas } & Moderate Distance & $\begin{array}{c}\$ 6.14 \\
(3.14-9.14) \\
\end{array}$ & $\begin{array}{c}\$ 8.48 \\
(1.61-15.33)\end{array}$ \\
\hline & Far Away Distance & $\begin{array}{c}\$ 12.46 \\
(8.45-16.47)\end{array}$ & $\begin{array}{c}\$ 21.37 \\
(8.97-33.77)\end{array}$ \\
\hline
\end{tabular}

Willingness to pay for proximity as an attribute of electricity generation source (Certain and uncertain choice observations):- Grant County.

\begin{tabular}{|c|c|c|c|}
\hline & \multirow{3}{*}{$\begin{array}{c}\text { Certain Choices } \\
\text { Weighted Mean WTP per } \\
\text { month (95\% Confidence } \\
\text { Interval) }^{\mathrm{a}}\end{array}$} & \multirow{3}{*}{ 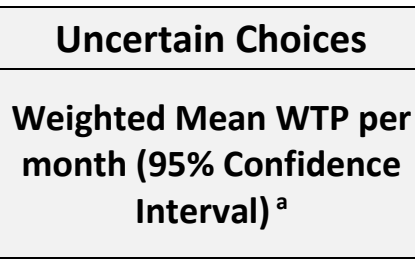 } \\
\hline & & & \\
\hline Energy Source & $\begin{array}{c}\text { Location of Facility } \\
\text { Relative to Respondents' } \\
\text { Residence (95\% } \\
\text { Confidence Interval) }\end{array}$ & & \\
\hline \multirow{2}{*}{ Wind } & Moderate Distance & $\begin{array}{c}\$ 5.27 \\
(3.37-7.18)\end{array}$ & $\begin{array}{c}\$ 8.37 \\
(3.25-13.48)\end{array}$ \\
\hline & Far Away Distance & $\begin{array}{c}\$ 7.93 \\
(5.56-10.31)\end{array}$ & $\begin{array}{c}\$ 12.47 \\
(5.74-19.2)\end{array}$ \\
\hline \multirow{2}{*}{ Natural Gas } & Moderate Distance & $\begin{array}{c}\$ 5.05 \\
(3.09-7.01) \\
\end{array}$ & $\begin{array}{c}\$ 6.43 \\
(1.80-11.06) \\
\end{array}$ \\
\hline & Far Away Distance & $\begin{array}{c}\$ 12.84 \\
(6.27-11.17) \\
\end{array}$ & $\begin{array}{c}\$ 14.91 \\
(7.52-22.31) \\
\end{array}$ \\
\hline
\end{tabular}


Willingness to pay per month for Wind as a renewable electricity generation source relative to Natural Gas (Certain and uncertain choice observations).

\begin{tabular}{|c|c|c|}
\hline & Certain Choices & Uncertain Choices \\
\hline & $\begin{array}{l}\text { Weighted Mean WTPa } \\
\text { (95\% Confidence Interval) }\end{array}$ & $\begin{array}{c}\text { Weighted Mean WTP } \\
\text { (95\% Confidence Interval) }\end{array}$ \\
\hline Monongalia County & $\begin{array}{c}\$ 26.35 \\
(11.91-40.79)\end{array}$ & $\begin{array}{c}\$ 32.57 \\
(3.14-61.98)\end{array}$ \\
\hline Grant County & $\begin{array}{c}\$ 10.38 \\
(2.67-18.07)\end{array}$ & $\begin{array}{c}\$ 1.06 \\
(-15.60-17.71)\end{array}$ \\
\hline
\end{tabular}




\section{APPENDIX IX: Multinomial Logit Models of Observations Separated by Order of Choice Sets (Choice set 1 vs. Choice set $2 \& 3$ )}

Multinomial logit model of Observations separated by Order of Choice Sets (Choice set 1 vs.

Choice set $2 \& 3$ ) - Monongalia County.

\begin{tabular}{|l|c|c|c|}
\hline \multicolumn{1}{|c|}{ VARIABLE } & $\begin{array}{c}\text { POOLED } \\
\text { MONONGALIA } \\
\text { COUNTY } \\
\text { SAMPLE }\end{array}$ & $\begin{array}{c}\text { FIRST OPTION } \\
\text { CHOICES }\end{array}$ & $\begin{array}{c}\text { SECOND \& } \\
\text { THIRD OPTION } \\
\text { CHOICES }\end{array}$ \\
\hline WIND_MODERATE & $0.253^{* *}$ & 0.391 & 0.163 \\
\hline WIND_FAR & $0.312^{* *}$ & 0.429 & $0.263^{*}$ \\
\hline NGAS_MODERATE & $-0.212^{*}$ & -0.061 & $-0.322^{* *}$ \\
\hline NGAS_FAR & $0.670^{* * *}$ & $0.994^{* * *}$ & $0.623^{* * *}$ \\
\hline ASC_WIND & $2.708^{* * *}$ & $4.724^{* * *}$ & $2.062^{* * *}$ \\
\hline FEES & $-0.090^{* * *}$ & $-0.084^{* * *}$ & $-0.096^{* * *}$ \\
\hline AVERAGE BILL & $-0.003^{*}$ & -0.004 & -0.002 \\
\hline SUPPORT_ARPS & $0.626^{* * *}$ & 0.553 & $0.689^{* * *}$ \\
\hline SEECOAL_H & -0.249 & -0.077 & -0.308 \\
\hline SEEWIND_H & 0.171 & 0.373 & 0.044 \\
\hline CONCERN_BILL & $-0.411^{*}$ & -0.612 & -0.333 \\
\hline INVEST_LESS POLLUTION & 0.332 & 0.032 & $0.473^{*}$ \\
\hline NEG ATTITUDE COAL & $0.733^{* *}$ & 0.413 & $0.888^{* * *}$ \\
\hline NEG IMPACTS NGAS & 0.009 & 0.012 & 0.010 \\
\hline NEG IMPACTS WIND & $-0.041^{* * *}$ & $-0.046^{* * *}$ & $-0.039^{* * *}$ \\
\hline GENDER & 0.105 & -0.109 & 0.173 \\
\hline AGE & $-0.016^{* *}$ & $-0.032^{* *}$ & -0.010 \\
\hline ENV AFFILIATION & 0.336 & 0.388 & 0.306 \\
\hline 4 YEAR COLLEGE & -0.062 & -0.243 & -0.001 \\
\hline NUMBER OF OBSERVATIONS & 927 & 309 & 618 \\
\hline LOG LIKELIHOOD & -430.95 & -133.62 & -290.90 \\
\hline \hline
\end{tabular}

$* * * 1 \%$ significance, $* * 5 \%$ significance, $* 10 \%$ significance 
Multinomial logit model of Observations Separated by Order of Choice Sets (Choice set 1 vs. Choice set $2 \& 3$ ) - Grant County.

\begin{tabular}{|l|c|c|c|}
\hline \multicolumn{1}{|c|}{ VARIABLE } & $\begin{array}{c}\text { POOLED } \\
\text { GRANT COUNTY } \\
\text { SAMPLE }\end{array}$ & $\begin{array}{c}\text { FIRST OPTION } \\
\text { CHOICES }\end{array}$ & $\begin{array}{c}\text { SECOND \& THIRD } \\
\text { OPTION CHOICES }\end{array}$ \\
\hline WIND_MODERATE & -0.132 & -0.154 & -0.104 \\
\hline WIND_FAR & $0.282^{* * *}$ & 0.199 & $0.310^{* * *}$ \\
\hline NGAS_MODERATE & $-0.193^{* *}$ & -0.228 & $-0.220^{* *}$ \\
\hline NGAS_FAR & $0.438^{* * *}$ & $0.570^{* * *}$ & $0.431^{* * *}$ \\
\hline \hline ASC_WIND & $1.341^{* * *}$ & 0.782 & $1.487^{* *}$ \\
\hline FEES & $-0.096^{* * *}$ & $-0.113^{* * *}$ & $-0.086^{* * *}$ \\
\hline AVERAGE BILL & -0.001 & 0.001 & 0.002 \\
\hline SUPPORT_ARPS & 0.161 & -0.160 & 0.302 \\
\hline SEECOAL_H & -0.262 & -0.244 & 0.292 \\
\hline SEEWIND_H & $-0.333^{*}$ & -0.271 & -0.332 \\
\hline CONCERN_BILL & 0.131 & -0.0814 & 0.255 \\
\hline INVEST_LESS POLLUTION & $0.552^{* * *}$ & $0.659 * *$ & $0.521^{* * *}$ \\
\hline NEG ATTITUDE COAL & $0.763^{* * *}$ & $1.065^{* *}$ & $0.659^{* *}$ \\
\hline NEG IMPACTS NGAS & 0.004 & -0.003 & -0.006 \\
\hline NEG IMPACTS WIND & $-0.024 * * *$ & $-0.022^{* * *}$ & $-0.025^{* * *}$ \\
\hline GENDER & 0.195 & 0.307 & 0.138 \\
\hline AGE & -0.005 & -0.001 & -0.006 \\
\hline ENV AFFILIATION & $-1.198^{* * *}$ & -1.049 & $-1.273^{* *}$ \\
\hline 4 YEAR COLLEGE & -0.254 & -0.153 & -0.294 \\
\hline \hline NUMBER OF OBSERVATIONS & 1150 & 381 & 769 \\
\hline LOG LIKELIHOOD & -627.24 & -195.42 & -428.05 \\
\hline \hline
\end{tabular}

$* * * 1 \%$ significance, $* * 5 \%$ significance, $* 10 \%$ significance 


\section{APPENDIX X: Assessing the Effect of Weighting Observation (Weighted and Unweighted Multinomial Logit Models.}

Multinomial logit models of Grant County and Monongalia County sampled populations (Weighted vs. Unweighted).

\begin{tabular}{|c|c|c|c|c|}
\hline VARIABLE & $\begin{array}{l}\text { MONONGALIA } \\
\text { COUNTY } \\
\text { SAMPLE } \\
\text { (UNWEIGHTED) }\end{array}$ & $\begin{array}{l}\text { MONONGALIA } \\
\text { COUNTY } \\
\text { SAMPLE } \\
\text { (WEIGHTED) }\end{array}$ & $\begin{array}{c}\text { GRANT } \\
\text { COUNTY } \\
\text { SAMPLE } \\
\text { (UNWEIGHTED) }\end{array}$ & $\begin{array}{c}\text { GRANT } \\
\text { COUNTY } \\
\text { SAMPLE } \\
\text { (WEIGHTED) }\end{array}$ \\
\hline WIND_MODERATE & $0.253^{* *}$ & 0.113 & -0.132 & -0.111 \\
\hline WIND_FAR & $0.312^{* *}$ & $0.287 * *$ & $0.282 * * *$ & $0.320 * * *$ \\
\hline NGAS_MODERATE & $-0.212^{*}$ & -0.185 & $-0.193 * *$ & $-0.206 * *$ \\
\hline NGAS_FAR & $0.670 * * *$ & $0.667^{* * *}$ & $0.438^{* * *}$ & $0.431^{* * *}$ \\
\hline ASC_WIND & $2.708^{* * *}$ & $2.10 * * *$ & $1.341^{* * *}$ & $1.108^{* *}$ \\
\hline FEES & $-0.090 * * *$ & $-0.085 * * *$ & $-0.096 * * *$ & $-0.096 * * *$ \\
\hline AVERAGE BILL & $-0.003^{*}$ & -0.002 & -0.001 & -0.001 \\
\hline SUPPORT_ARPS & $0.626 * * *$ & $0.505^{* *}$ & 0.161 & 0.148 \\
\hline SEECOAL_H & -0.249 & -0.100 & -0.262 & $-0.316 * *$ \\
\hline SEEWIND_H & 0.171 & $0.837 * * *$ & $-0.333^{*}$ & -0.293 \\
\hline CONCERN_BILL & $-0.411^{*}$ & -0.020 & 0.131 & 0.254 \\
\hline INVEST_LESS POLLUTION & 0.332 & -0.071 & $0.552 * * *$ & $0.395 * *$ \\
\hline NEG ATTITUDE COAL & $0.733^{* *}$ & $0.532 * *$ & $0.763 * * *$ & $0.734^{* * *}$ \\
\hline NEG IMPACTS NGAS & 0.009 & -0.0003 & 0.004 & 0.004 \\
\hline NEG IMPACTS WIND & $-0.041 * * *$ & $-0.044 * * *$ & $-0.024 * * *$ & $-0.025^{* * *}$ \\
\hline GENDER & 0.105 & $0.319 *$ & 0.195 & 0.060 \\
\hline AGE & $-0.016 * *$ & -0.012 & -0.005 & 0.001 \\
\hline ENV AFFILIATION & 0.336 & $0.749 * * *$ & $-1.198 * * *$ & $-1.002 * *$ \\
\hline 4 YEAR COLLEGE & -0.062 & 0.169 & -0.254 & -0.069 \\
\hline NUMBER OF OBSERVATIONS & 927 & 927 & 1150 & 1150 \\
\hline LOG LIKELIHOOD & -430.95 & -439.38 & -627.24 & -628.34 \\
\hline
\end{tabular}

$* * * 1 \%$ significance, ${ }^{* *} 5 \%$ significance, $* 10 \%$ significance 


\section{APPENDIX XI: Assessment of the Representativeness of Sample Population Compared to West Virginia Population.}

In order to justify the extrapolating of policy implications of this study to the rest of the state of West Virginia, respondents' opinions on renewable energy expressed in this study were compared to a state-wide study of consumer's attitudes towards renewable energy (CBER, 2009). The result of this study showed respondents in both counties agreed (strongly to somewhat agree) with the statement "It is important to invest in power plants that generate the least amount of pollution" (Monongalia county: 81\% vs. Grant County: 72\%). When respondents were asked about their level of agreement to the statement "I would be willing to pay more for electricity that is generated with less pollution than current energy sources (mainly coal)", a much lower percentage of the sampled population in both counties (Monongalia county: 37\% vs. Grant County: 18\%) agreed with the statement (strongly to somewhat agree). Over 64\% of the sampled population in Grant County compared to $44 \%$ in Monongalia County indicated they were not willing to pay a premium for electricity that is generated with less pollution.

The trends in opinions expressed by the sampled population in this study on the need to invest in less polluting electricity generation sources and their willingness to pay a premium for such an energy source were very similar to the opinions expressed by respondents of the CBER (2009) study on the need to promote the purchases of renewable energy by homeowners in West Virginia. CBER (2009), found that the majority (78\%) of respondents believed the state of West Virginia should promote the purchases of renewable energy by home owners ${ }^{13}$. In the CBER, 2009 study, the question "should the state of West Virginia promote the purchase of renewable energy

\footnotetext{
${ }^{13}$ Renewable and alternative energy included solar panels, small wind turbines by home owners and small businesses. Sampled population was 432 individuals.
}

217 
such as solar panels, small wind turbines or geothermal systems by homeowners and business" was limited individual consumer investment in cleaner energy sources.

On the other hand, the question "It is important to invest in power plants that generate the least amount of pollution" presented to respondents in this study was limited to the provision of renewable and alternative energy through utility providers. Even though the questions presented in CBER (2009) and this study on the need to promote (invest or purchase) renewable energy and alternative energy in West Virginia were not the same; they were fairly related to each other ${ }^{14}$. CBER also found that only $24.8 \%$ of the sampled population were willing to pay a positive premium for electricity generated from renewable alternative sources (wind, solar, biomass, low impact hydro power or waste coal). The premium that respondents were willing to pay ranged from "up to $10 \%$ " to "more than $20 \%$ " of the electricity supplied to consumers.

A significant share of the sampled population (22.0\%) in the CBER, 2009 study indicated they did not know if they were willing to pay a positive premium for renewable electricity. A substantial share of the respondents (53.2\%) in the statewide study were not willing to pay a positive premium for renewable and alternative electricity. Adjusting for respondents who did not know whether they were willing to pay a premium for renewable electricity, at least $32 \%$ of the respondents who were sure about their response were willing to pay a positive premium for renewable and alternative electricity compared to $68 \%$ who were not willing to pay a premium.

In order to satisfy the mandated of the ARPS policy, respondents in the two counties surveyed were given a number of possible scenarios that utility providers can use to increase its

\footnotetext{
${ }^{14}$ CBER (2009) in a state wide study asked respondents: "should the state of west Virginia promote the purchase of renewable energy such as solar panels, small wind turbines or geothermal systems by homeowners and business".
}

\section{8}


share of renewable and alternative electricity generation. Given the option of "construct wind turbines at new sites" as an alternative option, respondents were asked to express opinions on whether utility providers should make such an option a priority in order to satisfy the ARPS mandate. Majority of the sampled population in both counties (Monongalia county: 60\% vs. Grant County: $60.7 \%$ ) asserted that utility providers should make the construction of wind farms at new sites a priority (high and low) to satisfy the ARPS mandate.

CBER 2009, also found that the majority of the sampled population across the state $(69.2 \%)$ agreed with the statement: "West Virginia should encourage more large-scale wind farms as an economic development strategy". Moreover, CBER (2009), also found that $70.4 \%$ of the sampled population across the state believed that "West Virginia should support small-scale wind power for homes or business use".

Based on the results presented above, it can be asserted that, the opinions expressed by the Grant County sampled population (compared to Monongalia county) on the need to promote renewable/alternative energy and WTP for such sources of energy more closely reflect that of respondents in the state wide study presented by CBER (2009). Moreover, demographic characteristics of the Grant County sampled population and that of the state wide study (CBER, 2009), such as median income level (Grant County: $\$ 35,000-\$ 49,999$ vs. CBER 2009: $\$ 20,000-$ $\$ 40,000)^{15}$ and the share of respondents with at least a 4 year college degree (Grant County: $24.8 \%$ vs. CBER 2009: 25.2\%) ${ }^{16}$, closely reflected each other. The share of respondents with at least a 4year college degree $(56 \%)$ and median income level $(\$ 50,000-\$ 74,999)$ within the Monongalia

\footnotetext{
${ }^{15}$ Median Income level excludes those who refused to answer the question (Grant County: 10.8\% vs. CBER, 2009: $32.9 \%$ )

${ }^{16}$ Education level computation includes percentage of the population who refused to answer the question (Grant County: $3.2 \%$ vs. CBER 2009: $3.5 \%)$ 
county sampled population were much higher compared to the sampled population of the state wide study presented by CBER, 200917.

Based on the results presented above, it can be asserted that policy implications based upon the Grant County sampled population opinions and WTP a premium for renewable/alternative electricity are more closely representative of the state population of West Virginia than the Monongalia County sampled population.

${ }^{17}$ According to the census bureau, the median income level and the share of the total population with at least a 4 year college degree (25 years and above) in West Virginia (2010-2014) were \$41,576(2014 dollars) and 18.7\% respectively. 


\section{APPENDIX XII: Discussion on the "Far Away" Location Attribute as a Within State vs. Potential Out of State Location.}

Within the choice experiment section, respondents were referred to an appendix that clearly defined the three levels of the attribute location (near, moderate and far). The levels were defined both as a measure of possible sighting of the facility and distance measurement relative to the respondent's current residential location. Moreover, within the attitudinal section of the survey, respondents were introduced to the potential positive and negative impact of renewable and alternative electricity generation on the local community (questions 11 and 12). Employment prospect (job creation) was included as a potential economic impact. As such, it was assumed that respondents understood that renewable and alternative electricity generation has some employment prospects for the state, county or local community.

After the choice experiment section, respondents were informed that renewable and alternative electricity generation investments have positive economic benefits. Respondents were asked to express their opinions on where these economic benefits should be concentrated. Four locations that ranged from "immediate community where the facility is located" to the rest of the country "nationally" were presented to respondents as possible locations where the benefits from such investments are most important. Respondents were given the option to choose all that applied. Results of opinions expressed by respondents on this question are presented in section 5.3 (table 5.15).

The option "Within the state of West Virginia" was chosen $67 \%$ and $63 \%$ of the time by respondents in Monongalia County and Grant County respectively. The option to allocate the economic benefits of renewable and alternative electricity generation investments "nationally" (out of state) was chosen the least number of times by respondents in both counties (Monongalia 
County: 45\% and Grant County: 31\%). The options "within the immediate community where the facility is located" and "anywhere within the county where the facility is located" ranked second and third respectively as the location where the economic benefits from renewable and alternative energy investments should be concentrated.

Based on these results, it can be asserted that concentrating the economic benefits of renewable and alternative energy investments within the state of West Virginia, was more important to the respondents in both counties. Moreover, within each county's sampled population, respondents mean WTP to locate a particular electricity generation source (wind or natural gas) at the far away locations were higher than the moderate. This implied that the economic benefits associated with renewable and alternative energy investments were as important to respondents as the disamenities associated with locating these facilities close to their residence.

From these observations, it can be asserted that a combination of economic benefits and attributes associated with a facility (including potential disamenities from location attribute) lead to choices made by respondents based on self-interest (attributes impacts to the individual) rather than an altruistic decision to spare other West Virginians from potential disamenities associated with renewable and alternative energy investments. If the intent of respondents while making their choices were to spare other West Virginians from potential dismenities associated with electricity generated from wind or natural gas (locate facility far away out of state), then their mean WTP for electricity generated from wind or natural gas at the "moderate location" will be much higher than the respective "far away" locations for each energy source. 